Universidade de São Paulo

Faculdade de Filosofia, Ciências e Letras de Ribeirão Preto

Departamento de Química

Programa de Pós-Graduação em Química

\title{
"Ação de corantes fotossensíveis em meio homogêneo e micro heterogêneo de lipossomos no controle do crescimento de Streptococcus mutans"
}

Tony de Paiva Paulino

Tese apresentada à Faculdade de Filosofia, Ciências e Letras de Ribeirão Preto da Universidade de São Paulo, como parte das exigências para a obtenção do título de Doutor em Ciências. Área: Química.

Ribeirão Preto - SP

2006 
Universidade de São Paulo

Faculdade de Filosofia, Ciências e Letras de Ribeirão Preto

Departamento de Química

Programa de Pós-Graduação em Química

\section{"Ação de corantes fotossensíveis em meio homogêneo e micro heterogêneo de lipossomos no controle do crescimento de Streptococcus mutans"}

Tony de Paiva Paulino

Orientador: Prof. Dr. Pietro Ciancaglini

Co-orientador: Prof. Dr. Antônio Cláudio Tedesco

Tese apresentada à Faculdade de Filosofia, Ciências e Letras de Ribeirão Preto da Universidade de São Paulo, como parte das exigências para a obtenção do título de Doutor em Ciências. Área: Química.

Ribeirão Preto - SP

2006 


\section{FICHA CATALOGRÁFICA}

Paulino, Tony de Paiva

“Ação de corantes fotossensíveis em meio homogêneo e micro heterogêneo de lipossomos no controle do crescimento de Streptococcus mutans”. Ribeirão Preto, 2006.

p. $115 \mathrm{p}: \mathrm{il} ; 30 \mathrm{~cm}$

Tese apresentada à Faculdade de Filosofia, Ciências e Letras de Ribeirão Preto, da Universidade de São Paulo, Área de Concentração: Química

Orientador: Ciancaglini, Pietro

1- Streptococcus mutans 2- Terapia fotodinâmica 3 Lipossomos 


\section{DEDICATÓRIA}

A meus pais ANÍSIO e PERPÉTUA, que nunca mediram esforços para que meu objetivo fosse alcançado, investindo em mim apoio, carinho, atenção e AMOR INCONDICIONAL.

À minha irmã MARCELA pelo incentivo, carinho e compreensão.

À FERNANDA pelo carinho e presença em momentos difíceis, pelo apoio e auxílio constante.

Às vovós GERALDAS que sempre estiveram junto a mim, amparando e guiando meus passos.

DEDICO 


\section{AGRADECIMENTOS}

Obrigado Pietro,

Pietro Ciancaglini, meu amigo e orientador, que muito me ENSINOU, fornecendo condições para crescer e produzir ciência. Foi assim que posso dizer que nos tornamos AMIGOS. Obrigado pelas instruções durante esta etapa, pela orientação no dia-a-dia com paciência e preocupação. Obrigado pela sua enriquecedora colaboração sempre presente e por você ser esta pessoa tão importante para mim.

O obrigado é pouco!!! 


\section{AGRADECIMENTOS}

Ao amigo, companheiro e eterno mestre, Professor Dr. Pietro Ciancaglini, filho da Dona Elisa, pela paciência e apoio em momentos difíceis e desafiadores, pelo amparo amigo e por sua participação em minha vida acadêmica.

Ao amigo, Professor Dr. Geraldo Thedei Júnior, da Universidade de Uberaba, pelo apoio teórico, pessoal e profissional. Seus conselhos e idéias foram e serão ponderantes em toda minha carreira. Suas geniosas idéias sobre PDT fizeram muita diferença neste trabalho.

Ao amigo, Professor Dr. Antonio Cláudio Tedesco, do Departamento de Química da F.F.C.L.R.P - USP - Grupo de Fotoquímica e Fotobiologia, pela coorientação, constante atenção, suporte técnico e sincera empatia.

Ao amigo Geraldo B. Londe, professor da Universidade Federal do Triângulo Mineiro - UFTM, pela atenção, amizade, exclusividade e apoio.

Aos amigos da pós-graduação: Ana Maria, Carol, Fernanda, Hérica, Kátia, Marcelle, Rosângela e Prislaine.

Maytê, obrigado pelo apoio técnico e principalmente pela amizade.

Aos amigos do laboratório de Sistemas Miméticos de Membrana: Rodrigo (Diguinho), Luis Eduardo (Dudu), Leonardo (Tchau), Roberto (Pub's), Maytê, Ricardo, Mariana, Juliana, Imaculada, Ricardo (Torrone).

Niltinho (Guaraldo) e Ivana...... o que seríamos de nós sem vocês!!!

Karina, Adriana e Vânia pela ajuda nos experimentos com os fibroblastos e nas análises fotoquímicas.

Aos professores Richard John Ward e Elisabete Zaniquelli pelos equipamentos e atenção empregados em meu trabalho.

Aos amigos da Universidade de Uberaba, minha progenitora, em especial aos amigos da Educação Física e a todos que participaram de minha formação acadêmica.

A todos os professores e funcionários do Departamento de química, principalmente Lâmia, Bel (Pessoa), André, Sônia, Maria e Losane.

Priscila Cerviglieri, pelas traduções e correções da língua inglesa.

Alcides, Geraldo, Marquinho pela assistência aos problemas hidráulicos e elétricos.

Tuca e Zé, da Faculdade de Medicina de Ribeirão Preto, pelas microscopias.

A CAPES e FAPESP pelo apoio técnico e financeiro 
"Meu andar é firme; meu anseio é forte;

ou eu encanto a vida ou desencanto a morte".

Paulo Diniz 
As invenscoess saa, sabretude,

o resultado de un trabalino teimose.

Alberto Santos Dumont 


\section{SUMÁRIO}

Resumo $i$

Abstract iii

Lista de Abreviaturas e siglas $v$

Lista de tabelas

Lista de Figuras

1. INTRODUÇÃO

1.1. Aspectos históricos da bactéria Streptococcus mutans

1.2. Taxonomia do Streptococcus mutans 2

1.3. Aquisição primária e transmissão de $S$. mutans 3

1.4. S. mutans e a cárie: $\quad 4$

1.5. Terapia fotodinâmica (TFD) 8

$\begin{array}{ll}\text { 1.5.1. Mecanismo de ação da TFD } & 9\end{array}$

1.5.2. Os processos fotofísicos e fotoquímicos que ocorrem durante a TFD

1.6. Agentes fotossensíveis

1.7. A fonte de luz

1.8. Efeitos da TFD

1.8.1. Mecanismos da TFD em microrganismos $\quad 21$

1.9. Lipossomos $\quad 22$

2. OBJETIVOS 24

3. MATERIAL E MÉTODOS

3.1. Equipamentos utilizados $\quad 26$

3.2. Material utilizado $\quad 27$

3.3. Streptococcus mutans $\quad \mathbf{2 8}$

3.3.1. Padronização das condições de crescimento de
Streptococcus mutans em meio líquido

3.3.2. Avaliação do consumo de carboidratos durante 0 crescimento de S. mutans

3.3.3. Determinação do número de Unidades Formadoras de Colônias (UFC's)

3.3.4. Avaliação do $\mathrm{pH}$ e densidade óptica do meio de cultivo durante o crescimento de $S$. mutans

3.3.5. Padronização do crescimento do biofilme de $S$. mutans 3.3.5.1. Padronização das condições de crescimento de $S$. mutans na placa de 24 poços (formação do biofilme)

3.4. Fibroblastos

3.4.1. Condições de crescimento dos Fibroblastos

3.5. Preparação da solução estoque dos Agentes Fotossensíveis Utilizados na TFD

3.5.1. Preparação da solução estoque de Rose bengal 32

3.5.2. Preparação da solução estoque de Protoprofirina IX $\mathbf{3 2}$

3.5.3. Preparação da solução estoque de Zinco Ftalocianina $(\mathrm{ZnPc})$

3.6. Preparação dos Lipossomos e ZnPc-lipossomos 32

3.6.1. Determinação do diâmetro médio dos lipossomos 33

3.6.2. Preparação do gradiente isopícnico de densidade de sacarose

3.7. Caracterização fotoquímica e fotofísica dos agentes 
fotossensíveis estudados

3.7.1. Determinação espectroscópica de absorção no estado estacionário dos compostos fotossensíveis Protoporfirina IX e Zinco ftalocianina

3.7.2. Determinação dos espectros de emissão de fluorescência no estado estacionário dos compostos fotossensíveis estudados

3.7.3. Determinação do rendimento quântico de fluorescência $\left(\Phi_{\mathrm{F}}\right)$ dos compostos estudados

3.7.4. Determinação do espectro de absorção resolvido no tempo

3.7.5. Determinação do rendimento quântico de produção de oxigênio singlete $\left(\Phi_{\Delta}\right)$

3.8. Constituição, descrição e montagem do fotopolimerizador de resina odontológica e caracterização espectral da luz emitida

3.9. Aplicação da Terapia fotodinâmica (TFD)

3.9.1. Avaliação dos efeitos citotóxicos da TFD aplicada ao $S$. mutans na presença ou ausência de diferentes agentes fotossensíveis

3.9.2. Avaliação da formação de biofilme após TFD

3.9.3. Avaliação dos efeitos citotóxicos da TFD aplicada nos fibroblastos na presença ou ausência de diferentes agentes fotossensíveis

3.9.4. Determinação da viabilidade celular

3.9.4.1. Ensaios com Azul Tripan

3.9.4.2. Ensaios com MTT

3.9.5. Pulso de carboidratos para avaliação da capacidade acidogênica de $S$. mutans

3.9.6. Pulso de glicose para avaliação da capacidade acidogênica de S. mutans após TFD

3.10. Obtenção das frações microssomais de membrana de Streptococcus mutans

3.11. Quantificação da proteína

3.12. Influência da TFD sobre a atividade ATPase total de fração microssomal de membrana de S. mutans

3.13. Expressão e análise de proteínas de estresse (Heat Shock Protein - HSP) em S. mutans após TFD

3.13.1. Cultivo e tratamento das células

3.13.2. Lise bacteriana para obtenção de proteínas de estresse (Heat Shock Protein - HSP) de S. mutans

3.14. Análise por SDS-PAGE e "Western Blotting"

3.15. Estudos de peroxidação lipídica em $S$. mutans: ação sobre a fração de membrana e em bactérias em meio planctônico

3.15.1 Fração de membrana

3.15.2. Bactérias em meio planctônico

3.16. Efeito da terapia fotodinâmica sobre o DNA de S. mutans

3.16.1. Emprego da TFD sobre as células

3.16.2. Extração de DNA genômico bacteriano

3.17. Microscopia Eletrônica de Transmissão do S. mutans

3.18. Descarte das células

4.1.1. Avaliação da capacidade acidogênica de $S$. mutans em meio planctônico após adição de diferentes carboidratos pulso de carboidratos. 
4.2. Caracterização fotoquímica dos agentes fotossensíveis e seu emprego na TFD sobre $S$. mutans e fibroblastos

4.2.1. Rose bengal

4.2.1.1. Caracterização fotoquímica do Rose bengal

4.2.1.2. Efeito da TFD sobre S. mutans e fibroblastos utilizando-se

4.2.2. Protoporfirina IX

4.2.2.1 Caracterização fotoquímica e fotofísica da Protoporfirina IX e seu emprego na TFD sobre $S$. mutans e fibroblastos

4.2.2.2. Efeito da TFD sobre $S$. mutans e fibroblastos utilizando-se a Protoporfirina IX

4.2.3. Zinco ftalocianina

74

74

4.2.3.1. Avaliação da incorporação de ZnPc aos lipossomos: construção, quantificação e localização do corante

4.2.3.2. Caracterização fotoquímica e fotofísica do Zinco ftalocianina

80

4.2.3.3. Efeito da TFD sobre S. mutans e fibroblastos utilizando-se a zinco ftalocianina

82

88

90

4.2.5. Localização dos agentes fotossensíveis em S. mutans

4.2.6. Avaliação da capacidade acidogenica de $S$. mutans após TFD com os diferentes agentes fotossensíveis

4.2.7. Avaliação da atividade ATPase total de fração de membrana de S. mutans após emprego da TFD

4.2.8. Avaliação do perfil eletroforético de proteínas do lisado bacteriano

4.2.9. Avaliação da expressão de proteínas de choque térmico em $S$. mutans após TFD com Rose bengal

4.2.10. Avaliação do perfil eletroforético de DNA de $S$. mutans após emprego de TFD na presença de diferentes agentes fotossensíveis

5- CONCLUSÃO

6- BIBLIOGRAFIA

105

115 


\section{RESUMO}

Desequilíbrios no desenvolvimento da microbiota bucal podem gerar algumas patologias e, entre elas, está a cárie dental, uma doença crônica - contagiosa, de etiologia multifatorial, mas extremamente relacionada à bactéria Streptococcus mutans, que através de seu metabolismo fermentativo destrói estruturas mineralizadas do dente.

Além disso, o aumento da resistência à antibioticoterapia, devido à existência do biofilme (também formado pelo $S$. mutans) e aos tratamentos bactericidas mal sucedidos, faz do desenvolvimento de técnicas antimicrobianas alternativas um importante foco nesta área de pesquisa. Assim, na busca de novas metodologias contra microrganismos, estudos usando a Terapia fotodinâmica (TFD) têm sido empregados para se obter a inativação de bactérias como o S. mutans.

A TFD é uma modalidade terapêutica em que há a integração de uma luz visível, um corante e oxigênio que quando interagem, levam à produção de diferentes espécies reativas de oxigênio (ERO's) que irão desencadear uma seqüência de eventos biológicos, resultando numa possível morte ou inativação celular, inclusive de microrganismos como o S. mutans.

O objetivo deste trabalho foi avaliar a ação da TFD sobre a bactéria S. mutans em meio planctônico ou formando biofilme. Assim, a metodologia padronizada possibilitou o cultivo da bactéria em meio líquido (planctônico) ou na forma de biofilme, tornando-se possível a realização de testes com a aplicação da terapia fotodinâmica. Uma análise das curvas de crescimento possibilitou avaliar o metabolismo anaeróbico de S. mutans que consome açúcares fermentáveis (glicose, frutose, sacarose e maltose), mostrando-se hábil na produção de ácidos.

Conforme proposto, um fotopolimerizador de resina odontológica foi empregado como fonte de luz na TFD. Esta luz é emitida em comprimentos de onda variáveis (possível graças à troca do filtro de luz do equipamento) que fotoativam os diferentes corantes empregados tais como: Rose bengal, a Protoporfirina IX (PPIX) e a Zinco ftalocianina. Estes agentes fotossensiveis, depois de irradiados, produzem espécies reativas de oxigênio, principalmente o oxigênio singlete, que leva à inativação bacteriana observada nos experimentos realizados. Em contrapartida, as concentrações de luz e corantes empregados na inativação bacteriana apresentaram valores de baixa toxicidade para culturas de fibroblastos. 
Além disso, a grande diferença entre as concentrações de corante que causa a morte da bactéria na presença e na ausência de luz, indica que os compostos produzidos pela fotoativação são os responsáveis pela morte bacteriana em meio planctônico. Quanto ao biofilme formado por $S$. mutans, é possível promover uma diminuição da sua formação tanto com a TFD quanto com o emprego de flúor.

Células irradiadas imediatamente após a adição do corante foram semelhantemente inativadas após TFD, podendo ser desconsiderada uma incubação prévia para que agente fotossensível fosse homogeneamente distribuído.

Aparentemente a TFD não acarretou em mudanças na atividade ATPase total extraída da membrana da bactéria. Os experimentos para a determinação da localização dos corantes na célula ou para a avaliação de sua capacidade acidogênica não foram conclusivos em relação à possibilidade das espécies reativas estarem causando danos à parede, membrana plasmática ou ainda em alguma biomolécula citoplasmática da bactéria. Em adição, os estudos da peroxidação lipídica, de análise do DNA e de proteínas de stress após a TFD não trouxeram nenhuma informação adicional conclusiva sobre o alvo específico das ERO's que causam a inativação bacteriana.

Esta metodologia, apesar de ainda não poder ser aplicada na clínica, poderá complementar as técnicas antimicrobianas convencionais, por ser uma metodologia simples, de fácil emprego e baixo custo, podendo inclusive ser associada à possibilidade do uso de diferentes agentes fotossensíveis e adequada às necessidades da prática odontológica.

Palavras chave: Streptococcus mutans, Terapia Fotodinâmica, Fotopolimerizador de Resina odontológica, Biofilme. 


\begin{abstract}
Unbalance in the development of the mouth microbiota can originate some pathologies, dental cavity being among them - a chronic disease - contagious, of multifactorial etiology, but extremely related to the Streptococcus mutans bacteria, which, through its fermentative metabolism, destroys tooth mineralized structures.

Besides that, the increase in resistance to antibiotic therapy, due to the existence of biofilm (also formed by $S$. mutans) and to non successful bactericide treatments, makes alternative antimicrobial techniques development an important focus in this research area.

So, in search of new methodologies against microorganisms studies using the Photodynamic Therapy (PDT) have been employed to achieve inactivation of bacteria such as $S$. mutans.

PDT is a therapeutical modality in which there is an integration of a visible light, a dye and oxygen, when they interact, there is the production of different reactive oxygen species (ROS's) which will lead to a sequence of biological events, resulting in a possible cellular death or inactivation, including microorganisms such as S. mutans.

The aim of this work was to evaluate the action of PDT on $S$. mutans in planktonic medium or forming biofilm. So, the standardized methodology allowed the cultivation of bacteria in liquid media (planktonic) or in the biofilm form, making it possible to do tests with the application of the photodynamic therapy. The analysis of the growth curves allowed the evaluation of the anaerobic metabolism of S. mutans, which consumes fermentable sugars (glucose, fructose, sucrose and maltose), and is apt in acid production.

According to what is was proposed, a Hand Held Photopolymerizer was used as light source in PDT. This light is sent in variable wave lengths (made possible thanks to the change of the light filter in the equipment) which photoactivate the different dyes used, such as Rose bengal, Protoporphyrin IX (PPIX) and the Zinc Phtalocyanine. These photosensitive agents, after being irradiated, produce reactive oxygen species, specially the singlet oxygen, which leads to the bacterial inactivation observed in the experiments done. Nonetheless, the light concentrations and dyes used in the bacterial inactivation have shown low toxicity values for fibroblasts cultures.
\end{abstract}


Besides that, the high difference between the dye concentrations which causes the death of bacteria in the presence and absence of light indicates that the compounds produced by the photoactivation are the responsible for the bacterial inactivation in planktonic media.

As for the biofilm formed by $S$. mutans, it is possible to have a decrease in its formation with PDT as much as with the use of fluoride.

Cells irradiated immediately after the dye addition were similarly inactivated after PDT, so a previous incubation for the homogeneous distribution of the photosensitive agent can be discarded.

Apparently, the PDT did not cause changes in the total APTase activity extracted from bacteria membrane. The experiments for the determination of dye location in the cell or for the evaluation of its acidogenic capacity were not conclusive in relation to the possibility of reactive species to be causing damage to the cell wall, plasmatic membrane or still in some cytoplasmatic biomolecule of the bacteria.

In addition, the studies of lipidic peroxidation, DNA analysis and stress proteins after PDT did not bring any conclusive additional information about the specific target of ROS's that cause bacterial inactivation.

This methodology, although can't be applied in clinic yet, can complement the conventional antimicrobial techniques, being a simple methodology, of easy used and low cost, which can also possibly be associated to the use of different photosensitive agents and adjusted to the needs of odontological practice.

Keywords: Streptococcus mutans, Photodynamic Therapy, Hand Held Photopolymerizer, Biofilm. 


\section{LISTA DE ABREVIATURAS E SIGLAS}

Anti-GroEL: Anticorpo anti HSP70

BSA: Albumina bovina

DAB: (3,3'-Diaminobenzidina)

DMEM-F12: Meio Dulbecco's Modified Eagle /Medium F-12 Nutrient medium

DMF: Dimetilformamida

DMSO: Dimetilsulfóxido

DPPC: Dipalmitoil fostatidil colina

DTT: Ditiotreitol

FBS: Soro bovino fetal

GAR: anticorpo de cabra anti-lgG

HBSS: Hank's Balanced Salt Solution

HSP70: Heat Shock Protein $70 \mathrm{KDa}$ (proteína de choque térmico)

LPC: Lisofosfatidil colina

MES: Ácido 2-[N-Morfolino]etanosulfônico

MOPS: Ácido 3-[N-Morfolino]propanosulfonico

MTT: 3-(4,5-dimetil tiazol-2-il)-2,5-difenil brometo de tetrazolina

PPIX: Protoporfirina IX

RB: Rose bengal

SDS: Dodecil sulfato de sódio

TCA: Ácido tricloroacético

TLC: Cromatografia de camada delgada

Tris: Tris(hidroximetil)aminometano

TSA: Tryptic Soy Agar, TSA-Soybean-casein digest agar

TSB: Triptic Soy Broth, Soybean-casein digest medium

UFC: Unidades formadoras de colônia

ZnPc: Zinco ftalocianina 


\section{LISTA DE TABELAS}

Tabela 1: Diferenciação bioquímica de estreptococos do grupo mutans. $(\Delta)$ $11-89 \%$ das cepas são positivas; (+) - $90 \%$ ou mais das cepas são positivas; (-) - 90 \% ou mais das cepas são positivas; ND Não determinado.

Tabela 2: Valores dos picos de absorção máxima do corante PPIX $(0,2$ $\mu \mathrm{mol} / \mathrm{L}$ ), dissolvido em diferentes solventes, determinada conforme descrito em Material e Métodos.

70

Tabela 3: Valores de rendimento quântico de oxigênio singlete para a PPIX em tampão PBS ( $\mathrm{pH} 7,4)$, baseado na comparação com Feoforbide-a, conforme descrito em Material e Métodos.

72

Tabela 4: ZnPc-Lipossomo formado a partir de diferentes concentrações de $\mathrm{ZnPc}$ conforme descrito em Material e Métodos, item 3.6. Disposição dos resultados obtidos no espalhamento dinâmico de luz: polidispersão e diâmetro médio e o desvio é referente a média de 3 medidas realizadas com preparações distintas.

Tabela 5: Valores de rendimento quântico de oxigênio singlete determinados para o composto ZnPc-lipossomo, baseado no agente fotossensível padrão (Feoforbide-a), conforme descrito no item 3.7.5 de Material e Métodos. 


\section{LISTA DE FIGURAS}

Figura1: Microscopia eletrônica de transmissão de $S$. mutans. Cepas crescidas em meio completo, suplementado com glicose (50 mMol/L). Aumento de $25.000 \mathrm{x}$

Figura 2: A etiologia multifatorial da cárie: a dieta, o estado imunológico e a higiene bucal do hospedeiro e a microbiota bucal são fatores que, persistindo, poderão levar ao desenvolvimento da cárie desde que prevaleçam por um determinado período de tempo associados (KATZ et al., 1979).

Figura 3: Esquema representativo da aplicação da TFD em paciente com tumor: após a aplicação da droga (A), a mesma irá preferencialmente concentrar-se no órgão ou tecido doente (B) para que posteriormente seja realizada localmente a irradiação com luz $(\mathrm{C})$, levando as células doentes à morte e conseqüente cura da doença (D).

Figura 4: Reação do oxigênio singlete com grupos de moléculas importantes.

Figura 5: Estrutura química do Rose bengal (A), Protoporfirina IX (B) e Zinco Ftalocianina (C).

Figura 6: Lipossomo: representação de uma vesícula unilamelar cuja fase aquosa é inteiramente cercada por uma membrana formada por moléculas de fosfolipídeos, constituindo uma bicamada lipídica.

Figura 7: Fotopolimerizador de resina odontológica conforme descrito no Depósito de Patente $n^{\circ}$ : PI 0404223-9 (PAULINO et al., 2004b): Fotopolimerizador manual de resina odontológica com ponteira autoclavável (D), vista lateral do suporte filtro luz (C1), vista frontal do suporte filtro de luz (C2), compartimento lâmpada halógena $(A)$, filtro de luz (B) e setup de alimentação $(E)$.

Figura 8: Fluxograma de eventos da metodologia aplicada para o emprego da TFD em S. mutans.

Figura 9. Curvas de crescimento de $S$. mutans mostrando a variação da densidade óptica em $600 \mathrm{~nm}$ (A) e pH (B) em função do tempo de cultivo em meio TSB (-) ou meio completo (- - - -): sem fonte de carbono $(\triangle)$; na presença de $13 \mathrm{mmol} / \mathrm{L}$ de glicose $(O) ; 13$ $\mathrm{mmol} / \mathrm{L}$ xilose $(\mathbf{a})$ ou mistura de $13 \mathrm{mmol} / \mathrm{L}$ glicose com $13 \mathrm{mmol} / \mathrm{L}$ xilose $(\diamond)$. Cada ponto é a média de três experimentos com uma variação inferior a $5 \%$.

Figura 10. Concentração da glicose em função do tempo de crescimento de S. mutans em meio TSB suplementado $(\diamond)$ ou não $(O)$ com 13 $\mathrm{mmol} / \mathrm{L}$ xilose. Inserção: curva padrão de calibração usando um Kit de ensaio de glicose (PAULINO et al., 2003). Cada ponto é a média de três experimentos com uma variação inferior a $5 \%$.

Figura 11. TLC dos carboidratos utilizados como referência (xilose e glicose) e do meio de cultura de $S$. mutans após crescimento em meio suplementado com $13 \mathrm{mmol} / \mathrm{L}$ glicose (linhas 1-4) por 4, 8, 12 e 24 horas, respectivamente ou com mistura de $13 \mathrm{mmol} / \mathrm{L}$ glicose e 13 $\mathrm{mmol} / \mathrm{L}$ xilose (linhas 5-8), por 4, 8, 12 e 24 horas, respectivamente. Linhas 9, 10 e 11 contêm padrões de glicose, xilose e mistura de glicose com xilose, respectivamente.

Figura 12. Placa de cultura (24 poços) após 12 horas de crescimento de $S$. mutans em meio completo suplementado com $1 \%(\mathrm{p} / \mathrm{v})$ de carboidrato. Coluna 1, maltose; 2 , xilose; 3 , glicose; 4, frutose; 5 , sacarose e 6 , controle (sem fonte de carbono). Linha A, sem flúor; $\mathrm{B}, \mathrm{C}$ e D com 1 , 3 e $5 \mathrm{mmol} / \mathrm{L}$ de $\mathrm{NaF}$, respectivamente.

Figura 13: Fotomicrografia do biofilme formado por $S$. mutans após crescimento durante 12 horas em meio completo suplementado 
com $1 \%$ de carboidrato $(\mathrm{p} / \mathrm{v})$ e/ou $\mathrm{NaF}(1,3$ e $5 \mathrm{mmol} / \mathrm{L})$ como indicado. $O$ controle refere-se ao biofilme formado em meio completo não suplementado com carboidrato (aumento de $100 \mathrm{X}$ ).

Figura 14: $\mathrm{pH}$ da suspensão celular de $S$. mutans suplementado com diferentes fontes de carbono. A suspensão celular foi

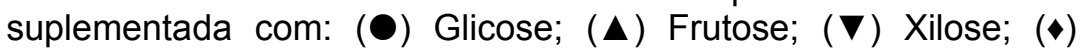
Maltose; (O) Sacarose e (a) sem nenhuma fonte de carbono. Os dados representam a média de valores $(n=3)$ e as barras de erros representam o desvio padrão.

Figura 15: (_ Espectro de absorção do Rose Bengal $4.0 \mu \mathrm{mol} / \mathrm{L}$ em tampão salino pH 7.4 (PBS) e (-----) espectro de transmitância do filtro original do fotopolimerizador de resina odontoógica.

Figura 16: Viabilidade de $S$. mutans na presença de variáveis concentrações de Rose bengal. A bactéria $\left(10^{3}\right.$ UFC) foi incubada com Rose bengal durante 10 minutos e incubada em meio de cultivo TSA durante 36 horas a $37^{\circ} \mathrm{C}$ na ausência de luz com $(\bullet)$ ou sem (०) irradiação de luz pelo fotopolimerizador. Inserção: viabilidade dos fibroblastos na presença de variáveis concentrações de Rose Bengal. As células $\left(10^{6}\right)$ foram incubadas com o corante durante 10 minutos e crescidas em DEMEN/F-12 por 24 horas no escuro com (ロ) ou sem ( $\square$ ) irradiação com o fotopolimerizador.

Figura 17: Espectros de absorção do corante PPIX na concentração de 3,0 $\mu \mathrm{mol} / \mathrm{L}$ e de emissão (Transmitância) da luz emitida pelo fotopolimerizador, realizado conforme descrito em Material e

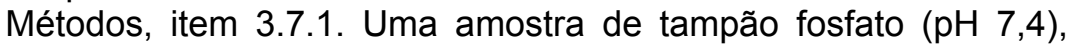
DMSO, Diclorometano e Acetona, todos sem o corante foi utilizada para calibração do equipamento (branco).

Figura 18: Espectro de emissão de fluorescência do corante PPIX. Excitação fixa em $452 \mathrm{~nm}$ com leitura a partir de 600 a até $800 \mathrm{~nm}$, conforme descrito em Material e Métodos.

Figura 19: Espectro de absorção do transiente do corante $\operatorname{PPIX}(0,2 \mu \mathrm{mol} / \mathrm{L})$, $0,21 \mu$ s após a excitação por pulso de laser em $355 \mathrm{~nm}$, mostrando a absorção máxima do triplete e o fotobranqueamento do estado fundamental, centrado em $350 \mathrm{~nm}$.

Figura 20: Viabilidade de $S$. mutans na presença de variáveis concentrações de Protoporfirina IX. A bactéria $\left(10^{3}\right.$ UFC) foi incubada com PPIX durante 10 minutos e incubada em meio de cultivo TSA durante 36 horas a $37^{\circ} \mathrm{C}$ na ausência de luz com $(\bullet)$ ou sem $(\circ)$ irradiação de luz pelo fotopolimerizador. Inserção: viabilidade dos fibroblastos na presença de variáveis concentrações de PPIX. As células $\left(10^{6}\right)$ foram incubadas com o corante durante 10 minutos e crescidas em DEMEN/F-12 por 24 horas no escuro com (匹) ou sem ( $\square$ ) irradiação com o fotopolimerizador.

Figura 21: Centrifugação em gradiente de densidade de sacarose: (A) Lipossomo DPPC:LPC (10:1); (B) Zinco ftalocianina em meio orgânico; (C) ZnPc-Lipossomo 3,72 $\mu \mathrm{mol} / \mathrm{L}$. (o) Fluorescência ZnPc: $\lambda_{\mathrm{ex}}=640, \lambda_{\mathrm{em}}=680 \mathrm{~nm}(\cdot)$ lipídeos: absorbância em $820 \mathrm{~nm}$, referente ao fosfato inorgânico obtido pela hidrólise ácida dos fosfolipídios e $(\boldsymbol{\square}) \%$ sacarose determinada por refratometria.

Figura 22: Espectros de absorção normalizados do corante $\mathrm{ZnPC}$ em meio etanólico e lipossomal. Faixa de varredura empregada: 400 a 800 $\mathrm{nm}$.

Figura 23: Espectro de emissão de fluorescência de ZnPC em meio lipossomal $(3,78 \mu \mathrm{mol} / \mathrm{L})$. Excitação fixa em $610 \mathrm{~nm}$, com faixa de varredura de 630 a $750 \mathrm{~nm}$, conforme descrito em Material e 
Métodos.

Figura 24: Espectro de absorção do transiente do corante ZnPC incorporado em lipossomos $(3,78 \mu \mathrm{mol} / \mathrm{L}), 0,21 \mu \mathrm{s}$ após a excitação por pulso de laser em $355 \mathrm{~nm}$, com faixa de varredura de 300 a $800 \mathrm{~nm}$, mostrando a absorção máxima do triplete e o fotobranqueamento do estado fundamental.

86

Figura 25: Espectro de absorção da ZnPc-Lipossomo 3,78 $\mu \mathrm{mol} / \mathrm{L}$ em tampão salino pH 7.4 (PBS) e (-----) espectro de transmitância do filtro de luz $(600-700 \mathrm{~nm})$ adaptado ao fotopolimerizador de resina odontológica.

Figura 26: Viabilidade de $S$. mutans na presença de variáveis concentrações de $\mathrm{ZnPc}$-Lipossomo. A bactéria $\left(10^{3} \mathrm{UFC}\right)$ foi incubada com ZnPcLipossomo durante 10 minutos e incubada em meio de cultivo TSA durante 36 horas a $37^{\circ} \mathrm{C}$ na ausência de luz com (•) ou sem (०) irradiação de luz pelo fotopolimerizador. Inserção: viabilidade dos fibroblastos na presença de variáveis concentrações de $\mathrm{ZnPc}$ Lipossomo. As células $\left(10^{6}\right)$ foram incubadas com o corante durante 10 minutos e crescidas em DEMEN/F-12 por 24 horas no escuro com (घ) ou sem ( $\square$ ) irradiação com o fotopolimerizador.

Figura 27. Fotomicrografia do biofilme formado por $S$. mutans após crescimento durante 2 horas em meio completo suplementado com $1 \%$ de sacarose $(\mathrm{p} / \mathrm{v})$ : RB, PPIX e $\mathrm{ZnPc}$ são respectivamente as células tratadas com os agentes fotossensíveis Rose bengal, Protoporfirina IX e ZnPc-lipossomo. O controle refere-se ao biofilme formado e não tratado com a TFD. O poço limpo refere-se à micrografia do poço sem nenhum biofilme crescido (aumento de $100 \mathrm{X})$.

92

Figura 28: Variação do $\mathrm{pH}$ observado em suspensão de $S$. mutans na presença de glicose $(50 \mathrm{mmol} / \mathrm{L})$ após terapia fotodinâmica: $(\bullet)$ Grupo Controle, $(\Delta)$ Rose bengal, (०) Protoporfirina IX e ( $\square$ ) ZnPclipossomo. Durante 10 minutos foi avaliado o $\mathrm{pH}$ da suspensão. Valores expressos em $\Delta \mathrm{pH}$ conforme descrito em Materiais e Métodos.

Figura 29: Eletroforese de gel de poliacrilamdia para o li8sado pretéico de $S$. mutans. A bactéria foi cultivada e posteriormente lisada com tampão de lise. As proteínas (50 $\mu \mathrm{g}$ por linha) separadas em SDSPAGE 7,5\%, PM: peso molecular padrão; 1: S. mutans estressado com NaCl; 2: S. mutans não estressado (controle negativo). Tratamentos conforme descrito em Material e Métodos.

. Imunoblot de proteínas (Heat Shock Protein 70). S. mutans foi cultivado e posteriormente lisados com tampão de lise. As proteínas $(50 \mu \mathrm{g}$ por linha) separadas em SDS-PAGE 10\%, foram transferidas para uma membrana de nitrocelulose, à qual foi incubada com anticorpo anti-GROEL $(1: 100)$ e anticorpo monovalente conjugado com peroxidase. 1: S. mutans submetido a TFD; 2: S. mutans irradiado com Luz proveniente do fotopolimerizador de resina odontológica; 3: $S$. mutans estressado com $\mathrm{NaCl}$ 4: $S$. mutans não estressado (controle negativo); 5: $S$. mutans tratado com Rose bengal. Tratamentos conforme descrito em Material e Métodos.

Figura 31. Gel de agarose das amostras de DNA obtidas de $S$. mutans. 1: $S$. mutans não submetido a TFD; 2 : $S$. mutans submetido a TFD com Rose bengal; 3: $S$. mutans submetido a TFD com PPIX e 4: $S$. mutans submetido a TFD com ZnPc-lipossomos. 


\section{INTRODUÇÃO}

\subsection{Aspectos históricos da bactéria Streptococcus mutans}

Em 1890, após estudos com lactobacilos provenientes de lesões cariogênicas, Miller propôs que o ácido lático fosse o produto final da fermentação dos carboidratos. Ele considerou que a cárie ocorria devido à dissolução da porção orgânica, através de um ataque ácido ao esmalte e dentina. Estes ácidos eram provenientes da fermentação lática, causada por bactérias a partir de alimentos que ficavam na boca após a alimentação (HARTLES \& McDONALD, 1950).

Dentre as bactérias existentes nestas lesões, destacam-se os estreptococus (Bactérias Gram positivas, ovóides e em cadeia) que, além de serem as bactérias mais comuns na boca, são também produtoras deste ácido e conseqüentemente cariogênicas. Assim, o termo cariogênico é aplicado apenas em algumas cepas de estreptococus capazes de produzir cáries em animais e ou seres humanos (WILLIANS \& ELLIOTT, 1979).

Uma característica comum às cepas cariogênicas é também a capacidade de armazenar polissacarídeos intracelulares semelhantes ao glicogênio. Estas reservas intracelulares podem ser metabolizadas a ácido lático quando os carboidratos exógenos são exauridos, estendendo o período durante o qual as cepas irão produzir ácidos. Portanto, no contexto da cárie dental, as cepas que não armazenam estes polissacarídeos somente irão produzir ácidos enquanto houverem açucares disponíveis na boca. Em contrapartida, cepas capazes de armazenar os polissacarídeos durante uma refeição do hospedeiro, poderão utilizá-los para o metabolismo energético após uma limpeza bucal.

Willians e Elliott (WILLIANS \& ELLIOT, 1979) listam ainda significantes aspectos relativos às bactérias cariogênicas:

- A capacidade de fermentar carboidratos e conseqüentemente reduzir o pH para aproximadamente $4-5$ (este $\mathrm{pH}$ é o valor no qual ocorre desmineralização do esmalte dental).

- A capacidade de produzir uma reserva de polissacarídeos a partir de açucares da dieta do hospedeiro. Esta reserva é usada como substrato de 
fermentação quando os carboidratos exógenos (da dieta do hospedeiro) não estão mais disponíveis. Cepas capazes de armazenar estes polissacarídeos são capazes de produzir ácidos por maiores períodos que cepas incapazes.

- A capacidade de produzir polissacarídeos extracelulares que permitem às células aderirem entre si e inclusive na superfície da parede dos dentes. Alguns polissacarídeos são formados principalmente a partir da sacarose (dextranos).

Dentre os estreptococus, o Streptococcus mutans aparenta-se a mais cariogênica espécie em evidência, apesar de algumas cepas de $S$. sanguis e $S$. oralis serem também causadores da cárie (MARSH, 1993).

Em 1924 o microbiologista Kilian Clarke desenvolveu seus estudos envolvendo a cárie dental, encontrando em lesões cariogênicas da dentina pequenos cocobacilos em cadeia, os quais apresentavam um formato mais oval do que esférico. Ele então sugeriu que estas células eram mutantes de estreptococus e as chamou de Streptococcus mutans (CLARKE, 1924). Clarke tentou provar a associação destes estreptococus com a doença cárie dental, mas infelizmente sua hipótese não foi aceita por outros. Na década de 60, o método de pesquisa gnobiótica animal estimulou novos estudos na microbiologia da cárie dental e só então a bactéria $S$. mutans foi convincentemente associada a esta doença (HAMADA, 1986).

\subsection{Taxonomia do Streptococcus mutans}

De acordo com a classificação do Bergey's Manual of Determinative Bacteriology (HOLT et al., 1994), o gênero Streptococcus inclui os grupos pyogenico, oral e anaeróbico dos estreptococus, assim como o grupo de outros estreptococus. As células são esféricas ou ovóides, com diâmetro médio de 0,5 - 2,0 $\mu \mathrm{m}$, ocorrendo em pares ou cadeia quando crescidas em meio líquido e corando-se Gram positivas. Estreptococus normalmente necessitam de meios enriquecidos para seu crescimento, seu metabolismo é fermentativo, produzindo principalmente lactato (não produzem gás). Os estreptococus são catalase negativa e comumente atacam células vermelhas (hemácias), apresentando uma coloração esverdeada ( $\alpha$-hemólise) ou um completo 
clareamento ( $\beta$-hemólise). Sua temperatura ótima de crescimento é $37^{\circ} \mathrm{C}$ sendo limitado a $25-45^{\circ} \mathrm{C}$. Estreptococus constituem a maior população presente na cavidade oral com várias espécies diferentes colonizando vários nichos ecológicos da boca. A diferenciação entre os grupos pyogenicos, orais e anaeróbicos pode ser trabalhosa e por esta razão, uma combinação entre informações é necessária para uma correta classificação (HOLT et al., 1994).

Especificamente para o $S$. mutans, as células possuem cerca de 0,5-0,75 $\mu \mathrm{m}$ de diâmetro, ocorrem em pares, cadeia curta ou média, sem cápsulas (Figura 1). Sob condições ácidas em meio líquido ou sólido estas cadeias podem atingir comprimentos de 1,5 a 3,0 $\mu \mathrm{m}$.

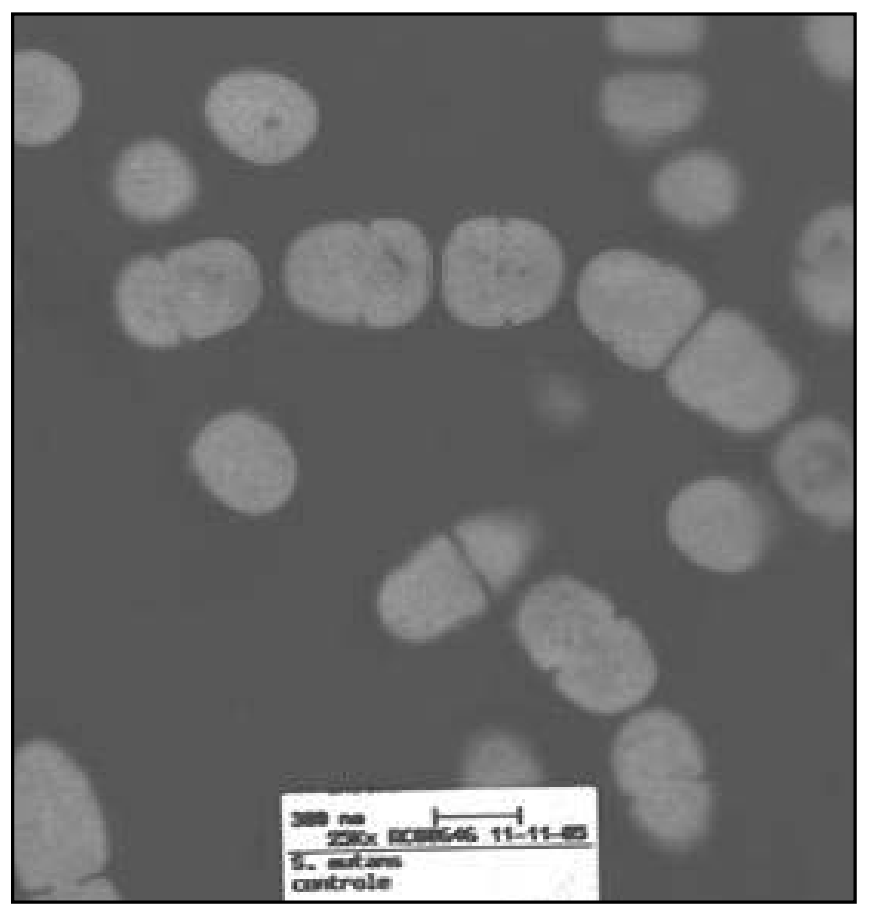

Figura 1: Microscopia eletrônica de transmissão de $S$. mutans. Cepas crescidas em meio completo, suplementado com glicose $(50 \mathrm{mMol} / \mathrm{L})$. Aumento de $25.000 \mathrm{x}$.

A diferenciação dentro do grupo dos estreptococos do grupo mutans é baseada em diferenças de reações bioquímicas (Tabela 1), por propriedades físico-químicas da superfície (van der MEI et al., 1991) ou até mesmo por técnicas moleculares (WHILEY \& BEIGHTON, 1998).

\subsection{Aquisição primária e transmissão de $S$. mutans}


Normalmente, antes do nascimento o feto humano é estéril. A contaminação da cavidade oral começa no primeiro contato táctil com a mãe e outras pessoas presentes no parto, inclusive o contato com o ar e outros equipamentos.

Tabela 1: Diferenciação bioquímica de estreptococos do grupo mutans. $(\boldsymbol{\Delta})-11-89 \%$ das cepas são positivas; (+) - $90 \%$ ou mais das cepas são positivas; (-) - $90 \%$ ou mais das cepas são positivas; ND - Não determinado.

\begin{tabular}{|c|c|c|c|c|c|c|}
\hline \multirow[b]{2}{*}{ Características } & \multicolumn{6}{|c|}{ Espécies } \\
\hline & S. mutans & S. ratus & S. sobrinus & S. cricetus & S. downei & S. ferus \\
\hline \multicolumn{7}{|l|}{ Fermentação de } \\
\hline Manitol & + & + & + & + & + & + \\
\hline Sorbitol & + & + & $\Delta$ & + & - & + \\
\hline Rafinose & + & + & + & + & - & - \\
\hline Inulina & + & + & + & $\Delta$ & + & + \\
\hline Melobiose & $\Delta$ & + & - & ND & ND & ND \\
\hline Trealose & + & + & $\Delta$ & + & + & ND \\
\hline \multicolumn{7}{|l|}{ Hidrólise de: } \\
\hline Arginina & - & + & - & - & - & - \\
\hline Esculina & + & + & $\Delta$ & $\Delta$ & - & + \\
\hline $\begin{array}{c}\text { Resistência à } \\
\text { bacitracina }\end{array}$ & + & + & + & - & - & - \\
\hline
\end{tabular}

A cavidade oral sem dentes de crianças, contém apenas superfície epitelial e as primeiras espécies colonizadoras não requerem uma superfície hospedeira. Dentre os primeiros colonizadores, incluem-se alguns estreptococus, Veillonella, Actinomyces, Fusobacterium e alguns bastonetes Gram negativos (KÖNÖNEM et al., 1994, 1999). Streptococcus salivarius está entre os primeiros colonizadores primários, ocupando o dorso da língua da criança (SOCRANSKY \& MANGANIELLO, 1971). Nos primeiros meses, a maioria das cepas detectadas são colonizadores transientes. Streptococcus sanguis e os estreptococus do grupo mutans são colonizadores permanentes apenas depois da primeira erupção dentária (BERKOWITZ et al., 1975).

\subsection{S. mutans e a cárie:}


É estimado que o corpo humano contem cerca de $10^{14}$ células, dentre as quais $90 \%$ não são do próprio hospedeiro. Dentre estas células, estão compreendidos os microrganismos pertencentes à microflora residente, os quais não são meramente passivos, mas contribuem direta e indiretamente para o desenvolvimento normal dos sistemas fisiológicos, de nutrição e defesa do hospedeiro. Muitas doenças são causadas por microrganismos diferentes da microbiota normal ou até mesmo por um desequilíbrio da microflora residente (MARSH, 2003).

Um exemplo deste desequilíbrio ocorre durante o desenvolvimento da cárie dental, visto que o Streptococcus mutans, uma bactéria Gram positiva, compõe uma parte substancial da microbiota presente na placa dental sujeita ao desenvolvimento desta doença. Esta bactéria usa os carboidratos presentes na dieta como fonte de energia para realização de um processo anaeróbico (principalmente fermentação lática), resultando na produção de ácidos orgânicos (PAULINO et al., 2003). Estes ácidos, baixam o pH para valores em torno de 5 na superfície do dente, induzindo assim sua desmineralização e causando a cárie (RADCLIFFE et al., 2002).

A cárie dental está inserida entre as mais significantes doenças crônicas contagiosas, as quais afetam principalmente países subdesenvolvidos, populações de baixa renda e/ou pacientes imuno comprometidos (KRASSE, 1988; MARSH, 2003). Já a existência da doença, se baseia na interação de fatores que produzirão a destruição irreversível de estruturas mineralizadas do dente, podendo chegar a proporções de comprometimento da vitalidade dental e da fixação do elemento dental no complexo maxilo-mandibular (MENAKER, 1980; CHARLOTTE et al., 2002; RADCLIFFE et al., 2002).

A cárie dental é uma doença comum, mundialmente espalhada e sua etiologia é multifatorial, sendo que os hábitos de vida do hospedeiro e a infecção por estreptococos do grupo mutans são os fatores mais importantes, ver esquema da Figura 2 (JOHNSON, 1991; BRATTHALL, 1997).

No mundo ocidental, a prevalência de cáries tem diminuído, apesar de que, cerca de $5-20 \%$ da população ainda permanece em grupos de risco (BOLIN, 1997; WATT \& SHEIHAM, 1999). Já em países em desenvolvimento, a taxa de cáries dentais está em constante evolução e pelo fato de que mais de $80 \%$ das crianças do mundo vivem nestes países, a cárie dental é considerada como um dos maiores 
problemas de saúde pública (CIRINO \& SCANTLEUBURY, 1998).

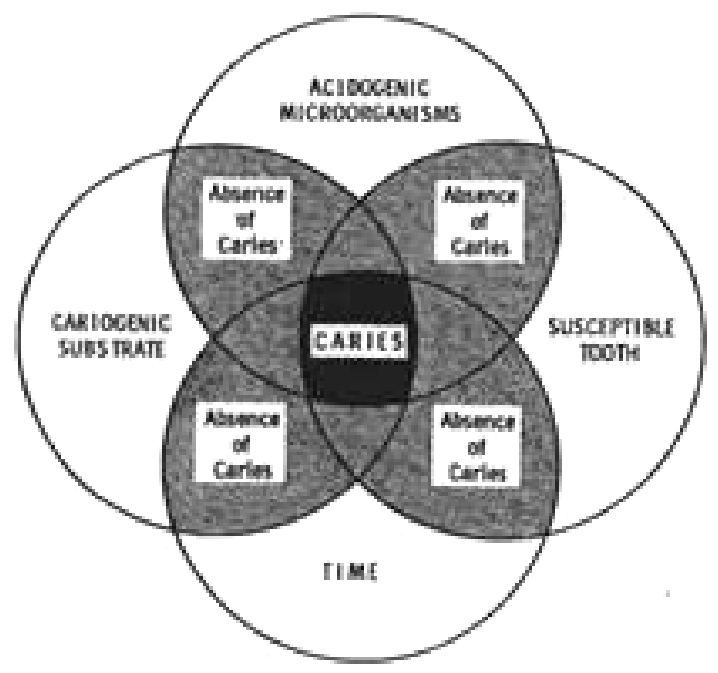

Figura 2: A etiologia multifatorial da cárie: a dieta, o estado imunológico, a higiene bucal do hospedeiro e a microbiota bucal são fatores que, persistindo, poderão levar ao desenvolvimento da cárie desde que prevaleçam por um determinado período de tempo associados (KATZ et al., 1979).

$\mathrm{Na}$ ocorrência de cárie, algumas espécies de fungos e bactérias podem predominar (BOYAR et al., 1989; MARSH et al., 1989). Dentre estas espécies, as bactérias Streptococcus sobrinus e o $S$. mutans compreendem uma parte substancial da contagem de células presentes na placa dental sujeita ao desenvolvimento de cárie e sua importância na etiologia da cárie dental é indiscutível (MIKKELSEN et al., 1981), sendo o S. mutans o principal agente etiológico (Mc NEIL \& HAMILTON, 2003). Apesar disso, a dieta, o estado imunológico, a higiene bucal do paciente (hospedeiro) e a microbiota bucal são fatores que, persistindo, poderão levar ao desenvolvimento da cárie desde que prevaleçam por determinado período de tempo associados, sendo variável de indivíduo para indivíduo (MENAKER, 1980).

A placa microbiana, formada por uma comunidade diversa de microrganismos, é um biofilme composto por numerosos e distintos tipos de bactérias que vivem próximos e justapostos à superfície do dente do hospedeiro (KOLENBRANDER, 2000). Este biofilme forma-se naturalmente no dente e sua presença é normalmente benéfica, pois contribui para estimular as defesas inatas do hospedeiro consistindo numa barreira contra outros microrganismos patogênicos. Assim, no biofilme sadio, 
encontram-se muitas espécies bacterianas, tais como Streptococcus sanguis, $S$. oralis, S. mitis, Actinomyces naeslundii, entre outros (MARSH, 1993).

É reconhecido atualmente que a formação do biofilme é um importante aspecto dentre várias doenças, se não a sua maioria, incluindo importantes patologias como endocardites valvulares, osteomielites, cáries dentais, infecções do ouvido médio, infecções de âmbito médico-hospitalar, implantes oculares e até infecções pulmonares em pacientes com fibrose cística. Este biofilme pode tolerar agentes antimicrobianos em concentrações de 10 a 1000 vezes maiores que o necessário para eliminar organismos planctônicos geneticamente iguais. Além disso, é normalmente mais resistente às fagocitoses, o que o torna extremamente difícil de ser erradicado dos tecidos vivos (JEFFERSON, 2004).

Com o objetivo de demonstrar os efeitos de diferentes fontes de carbono na ausência ou presença de diferentes concentrações de flúor, Paulino e colaboradores em 2004, concluíram que a bactéria $S$. mutans forma biofilme independente da fonte de carbono utilizada. Entretanto, a intensidade do biofilme formado é maior com sacarose, frutose, glicose e maltose, os quais são metabolizados pelo microrganismo. Além disso, independentemente do açúcar empregado, crescentes concentrações de flúor diminuem a formação deste biofilme (PAULINO et al., 2004).

Associado a estes fatores, o aumento da resistência à antibioticoterapia por bactérias como Streptococcus sobrinus e Streptococcus mutans faz do desenvolvimento de técnicas antimicrobianas alternativas um importante foco nesta área de pesquisa (MALIK et al., 1992).

Assim, agentes microbianos de amplo espectro têm sido desenvolvidos e mais especificamente tratando-se de microrganismos Gram positivos, novos compostos estarão sendo postos a prova nos próximos anos (WISE, 1998).

Desta forma, técnicas tradicionais têm sido empregadas na redução destes microrganismos, incluindo remoção mecânica e quimioterapia, sendo que o sucesso do tratamento está diretamente associado à colaboração e motivação do paciente (FEREZ et al., 1999; OLSVIK \& TENOVER, 1993).

Considerando-se a dificuldade no controle de microrganismos resistentes a antibióticos, alguns tratamentos têm sido desenvolvidos. Dentre eles, a produção de vacinas (SMITH, 2002), a terapia com o flúor (COX et al., 1999) e a antibioticoterapia (HIRASAWA \& TAKADA, 2002).

Neste sentido, Wallman e colaboradores (WALLMAN et al., 1998) comentam a 
dificuldade de se obter um decaimento longo e significativo da contagem de $S$. mutans após tratamento com clorexidina, havendo a necessidade de se combinar ao tratamento antimicrobiano convencional uma restrição dos níveis de sacarose da dieta do paciente, o que vem reforçar ainda mais a idéia de que o que se pode observar é o surgimento de diferentes formas de resistência aos tratamentos antimicrobianos convencionais.

Além disso, a penetração dos agentes quimioterápicos no biofilme bacteriano resulta em uma reduzida susceptibilidade dos microrganismos a este tipo de tratamento (MARSH \& BRADHAW, 1993).

$\mathrm{Na}$ busca de novas alternativas contra microrganismos, estudos usando a Terapia fotodinâmica (TFD) têm sido empregados para obter a inativação de bactérias (PAULINO et al., 2005), leveduras (BERTOLONI et al., 1984) e virus (SKILES et al., 1985), inclusive o HIV (MATTHEWS et al., 1988).

\subsection{Terapia fotodinâmica (TFD)}

Os organismos vivos foram evolutivamente se adaptando à radiação solar presente sobre a superfície terrestre e sob estas condições eles permanecem ilesos sob a luz visível. Entretanto, a presença simultânea de um corante fotossensibilizador e oxigênio, convertem esta inócua radiação em um potente agente de injúria sobre as células destes organismos. Raab, um estudante alemão, há dois séculos atrás, descreve na literatura o primeiro fenômeno científico destes efeitos (ROSENTHAL, 1989).

Assim, Oscar Raab no ano de 1899 em Munique, observou que o Paramecium podia ser eliminado na presença do corante acridina e luz, sendo que a luz ou a acridina quando empregadas separadamente eram inertes a este organismo. Além disso, ele demonstrou a dependência deste fenômeno com a presença do oxigênio e relatou o uso clínico da eosina como um fotossensibilizador para o tratamento do câncer de pele, Condyloma lata e Cutaneous lupus (SMITH, 1984). Desta forma, também próximo ao século 20 , von Tappeiner e Jodlbauer conduziram uma longa série de experimentos com a reação ocorrida entre a luz e os corantes, criando o termo "photodynamic erscheinung" (ação fotodinâmica) e demonstraram que uma grande variedade de corantes eram capazes de fotossensibilizar uma série de microrganismos (JARRATT et al., 1982). 
Além disso, nos últimos anos tem sido investigada a potencialidade do uso de corantes fotossensibilizáveis como agentes no tratamento fotoquimioterápico de tecidos tumorais, definindo-se uma nova linha de ação nesta área denominada terapia fotodinâmica (TFD).

\subsubsection{Mecanismo de ação da TFD}

TFD é uma modalidade terapêutica em que há a integração de uma luz visível, uma droga (chamada de fotossensibilizador ou corante) e oxigênio que normalmente está presente nos tecidos e meio reacional (Figura 3).

Este agente fotossensível pode ser normalmente uma molécula presente no meio (células ou tecidos), mas no caso específico da TFD é administrada uma droga ou uma pré-droga (Figura 3-A e 3-B), tornando-se esta, a primeira etapa da terapia. Em uma segunda etapa do tratamento, o tecido ou as células doentes, são expostos a uma luz visível (com um comprimento de onda específico) a qual é absorvida pelo agente fotossensível (Figura 3-C). Separadamente, o corante (em concentrações terapêuticas) ou a luz (em doses terapêuticas) não apresentam citotoxicidade.

Assim, a interação destes dois agentes na presença de oxigênio leva à produção de diferentes espécies reativas de oxigênio (ERO's) como, por exemplo, o oxigênio singlete entre os quais irão desencadear uma seqüência de eventos biológicos, resultando numa possível morte celular (Figura 3-D) (GOMER et al.,1989;HENDERSON \& DOUGHERTY, 1992; SHARMAN et al., 1999).

Microrganismos têm sido empregados em uma ampla variedade de ensaios para determinar o mecanismo da ação fotodinâmica induzida por numerosos agentes fotossensíveis. Devido ao baixo alcance, por causa da vida curta dos intermediários reativos gerados, a localização do corante na célula alvo tem sido motivo de dúvidas. Desta forma, Dahl e colaboradores em 1988, sugerem que a penetração em células tem sido considerada essencial para a ação fotodinâmica de alguns corantes, enquanto que para outros, a ação fotodinâmica tem sido observada sem penetração (DAHL et al., 1988). 


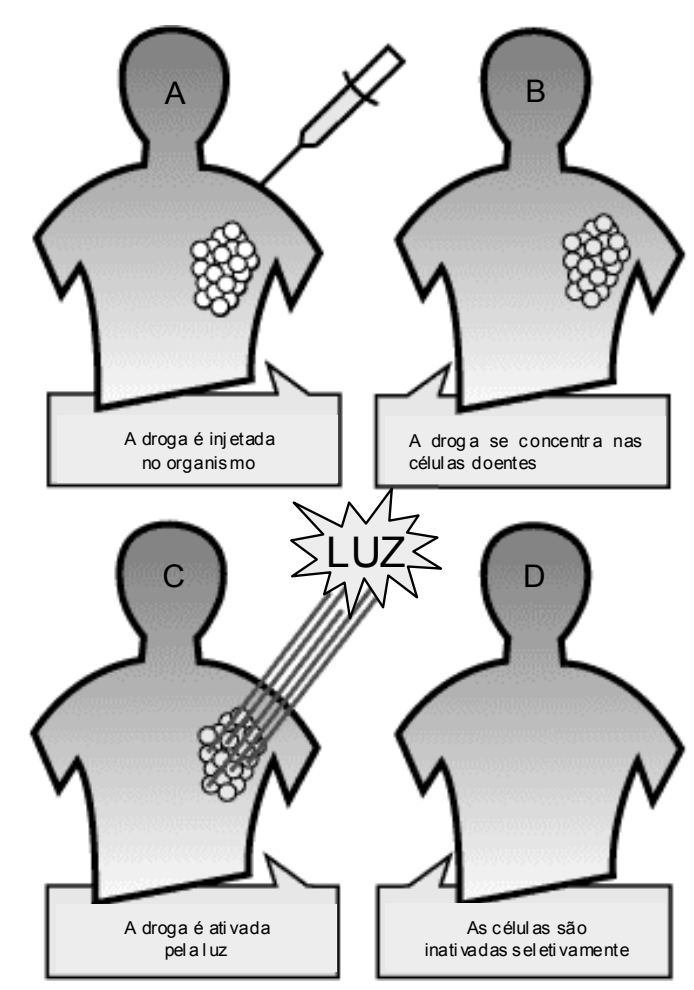

Figura 3: Esquema representativo da aplicação da TFD em paciente com tumor: após a aplicação da droga (A), a mesma irá preferencialmente concentrar-se no órgão ou tecido doente (B) para que posteriormente seja realizada (localmente) a irradiação $(C)$, levando as células doentes à morte e conseqüentemente à cura da doença (D).

Em relação ao emprego da terapia para o controle de microrganismos, estudos usando luz laser indicam que certas bactérias podem ser eficientemente inativadas após a TFD com o emprego de azul de toluidina ou azul de metileno (USACHEVA et al., 2001) e até mesmo com moléculas mais complexas como a alumínio ftalocianina dissulfonada (BURNS et al., 1995) ou a Zinco Ftalocianina (MINNOCK et al., 1996).

Alguns estudos específicos indicam que certas bactérias orais incluindo $S$. mutans e S. sobrinus, entre outras, podem ser inativadas após TFD com azul de toluidina e azul de metileno (WILSON et al., 1993), alumínio ftalocianina dissulfonada (BURNS et al., 1995) após irradiação com luz laser, ou com o uso de Rose Bengal (PAULINO et al., 2005) fotossensibilizado por uma luz halógena.

A luz tem sido utilizada no tratamento de doenças desde a antiguidade. Muitas civilizações antigas utilizaram fototerapia, mas apenas neste último século ela foi utilizada como terapia reparadora. Segundo as recentes descobertas científicas dos 
pioneiros Finsen, Raab e Von Tappeiner, a combinação de luz e a administração de uma droga levam a uma fotoquimioterapia, agindo como uma ferramenta terapêutica (ACKROYD, 2001).

Alguns grupos têm descoberto que laseres de argônio ou hélio-neônio ( $\mathrm{He}-\mathrm{Ne}$ ) podem diminuir as contagens microbianas de agentes patógenos, podendo descontaminar regiões de tecido inflamado (MATEVSKI, 2003). Assim, como pode se observar, a maioria das aplicações de TFD está associada a uma luz laser, apesar de que, fontes de luz não laser também têm sido utilizadas (BRANCALEON \& MOSELEY, 2002).

Estudos desenvolvidos na última década indicam que 0 uso dos fotopolimerizadores manuais (fontes de luz não laser) não apresenta nenhum dano térmico ou fotoquímico (luz azul) à retina (SATROM et al., 1987; THACH, 1999) e completa ausência de qualquer dano visual ao paciente ou ao clínico por irradiações UV-A ou UV-B (COOK, 1986). Comparado à manutenção das fontes laser, seu custo é bastante inferior (ZOEPF, 2001).

Além disso, a possibilidade de contaminações por infecções bucais entre pacientes através da utilização do fotopolimerizador foi descartada, visto que estudos demonstraram que a desinfecção do equipamento, propositalmente contaminado com S. mutans, se dá facilmente após tratamento com agentes fenólicos (CAUGHMAN et al., 1989), além do que, há a possibilidade de se promover uma eficiente esterilização através de um processo de pasteurização ou autoclavagem.

\subsubsection{Os processos fotofísicos e fotoquímicos que ocorrem durante a TFD}

No diagrama de Jablonski (BONNETT, 1988), ilustrado no Esquema 1, estão representados os processos fotofísicos e fotoquímicos que um agente fotossensível pode sofrer após a absorção de radiação.

Após a absorção de um fóton de luz, o agente fotossensível passa a popular um estado excitado singlete mais energético $\left(S_{n}\right)$, de onde pode retornar para o seu estado fundamental pelo processo de relaxação física conhecido como conversão interna (ic) ou através do processo radioativo de emissão de fluorescência. As propriedades fluorescentes dos agentes fotossensíveis têm sido úteis para a visualização, localização e delineação da lesão maligna. Contudo, a ação fotodinâmica é dependente do processo de cruzamento intersistemas (isc), 
caracterizado pela inversão do spin eletrônico. Através deste processo, a molécula do agente fotossensível passa a popular os estados excitados tripletos $\left(T_{1}\right)$. A partir do estado tripleto, a droga fotossensibilizadora pode retornar para o estado fundamental pelo processo de conversão interna ou pelo processo de emissão de fosforescência $\left(k_{p}\right)(L A K O W I C Z, 1984)$.

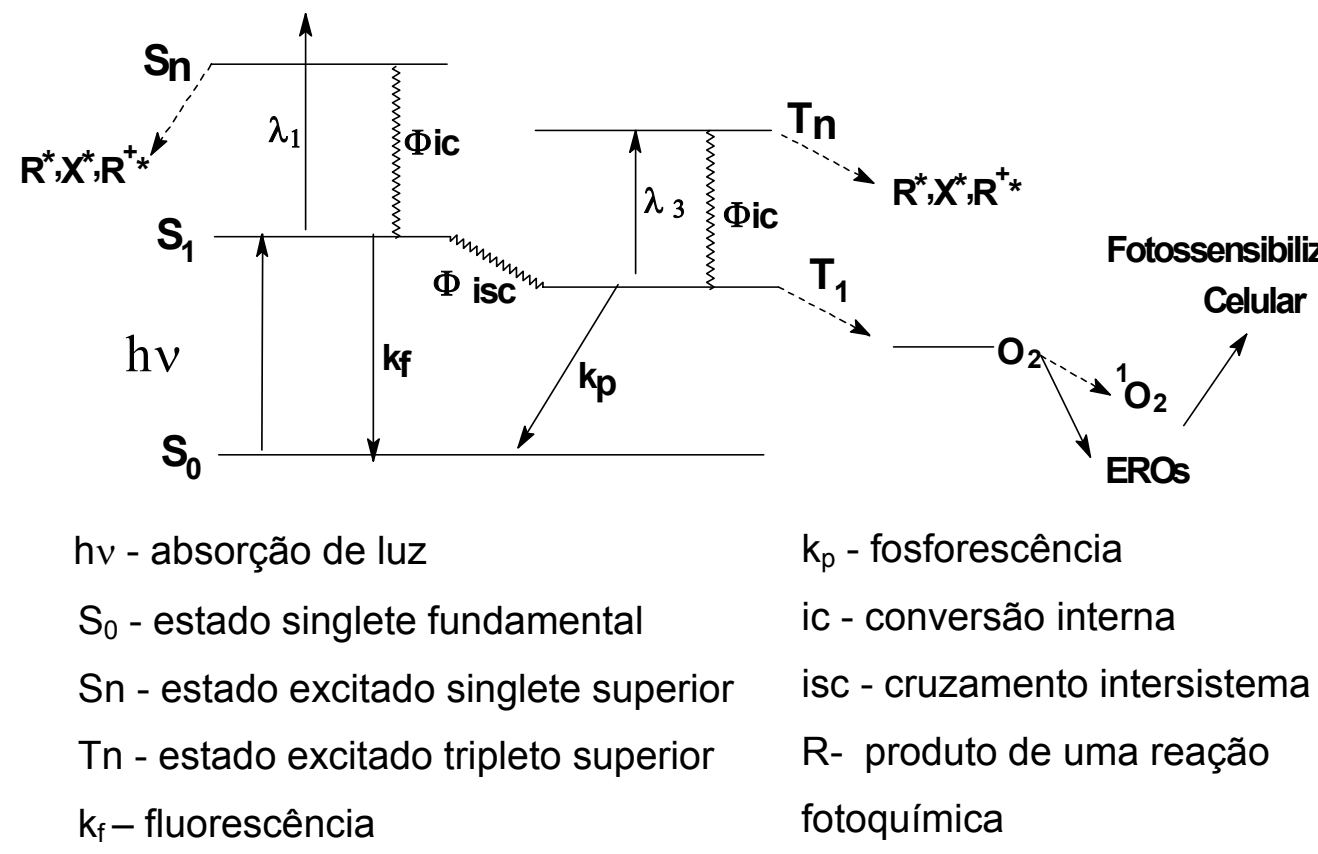

Esquema 1: Diagrama de Jablonski para um sistema fotoluminescente (LAKOWICZ, 1984).

De maior importância que os processos fotofísicos, entretanto, são as reações que a droga fotossensibilizadora pode sofrer neste estado excitado. A maioria dos dados disponíveis sobre a TFD sugerem um mecanismo comum de ação, onde o agente fotossensível tripleto na presença do oxigênio molecular presente no meio induz a produção de espécies reativas de oxigênio, (EROs) $\left({ }^{1} \mathrm{O}_{2},{ }^{\bullet} \mathrm{O}_{2}^{-},{ }^{\circ} \mathrm{OH}, \mathrm{H}_{2} \mathrm{O}_{2}\right)$ que atacam centros específicos dentro dos sistemas celulares, levando à apoptose celular (KESSEL et al., 1999). Os mecanismos de produção destas espécies reativas são descritos a seguir:

O mecanismo do Tipo I (FOOTE, 1991) parte do princípio de que o agente fotossensibilizante $\left({ }^{0} \mathrm{~F}\right)$, ao absorver energia luminosa, sofrerá mudança de nível energético para ${ }^{1} \mathrm{~F}$ (estado singleto) e possivelmente para ${ }^{3} \mathrm{~F}$ (estado tripleto) (Equação 1.1). Esta espécie formada (no estado tripleto), na presença de 
macromoléculas (Sub), sofrerá uma abstração de um átomo de hidrogênio ou uma reação de transferência de elétrons para estas diferentes macromoléculas biológicas (Sub), levando à produção de radicais livres e íons radicais (Equação 1.2). A espécie reduzida do agente fotossensível pode transferir um elétron ao oxigênio molecular presente no meio formando espécies reativas de oxigênio como peróxidos, ânion superóxido, etc (Equação 1.3). Este tipo de mecanismo de fotossensibilização, esquematizado abaixo:

$$
\begin{aligned}
& { }^{0} \mathrm{~F} \longrightarrow{ }^{1} \mathrm{~F} \longrightarrow{ }^{3} \mathrm{~F} \\
& { }^{3} \mathrm{~F}+\mathrm{Sub} \rightarrow \mathrm{Sub}^{+\bullet}+\mathrm{F}^{\bullet-} \\
& \mathrm{F}^{\bullet-}+{ }^{3} \mathrm{O}_{2} \rightarrow \mathrm{F}+\mathrm{O}_{2}^{-\bullet}
\end{aligned}
$$

Substrato: semioxidado; Sensibilizador: semi-reduzido.

$$
\begin{aligned}
& { }^{0} \mathrm{~F} \longrightarrow{ }^{1} \mathrm{~F} \longrightarrow{ }^{3} \mathrm{~F} \\
& { }^{3} \mathrm{~F}+\mathrm{SubH} \rightarrow \mathrm{FH}^{\bullet}+\mathrm{SubH}^{\bullet}
\end{aligned}
$$

$$
\mathrm{FH}^{\bullet-}+{ }^{3} \mathrm{O}_{2} \rightarrow \mathrm{F}+\mathrm{HO}_{2}^{-\bullet} \text { (ácido conjugado) }
$$

Outro caminho possível para a droga em seu estado excitado tripleto $\left({ }^{3} \mathrm{~F}\right)$ é o de transferência de energia para o oxigênio molecular $\left({ }^{3} \mathrm{O}_{2}\right)$ com formação de oxigênio singlete $\left({ }^{1} \mathrm{O}_{2}\right.$; Equação 1.4), generalizando assim a produção dos EROs. Esta espécie ativa de oxigênio reage rápida e indiscriminadamente com os mais variados materiais biológicos (Sub) como lipídios insaturados, aminoácidos, proteínas e ácidos nucléicos (Equação 1.5 e Figura 4), sendo apontado como o principal responsável pela inativação da célula tumoral ou pela morte de alguns microrganismos. Este tipo de reação de fotossensibilização é conhecido como do Tipo II (FOOTE, 1991).

$$
\begin{aligned}
& { }^{3} \mathrm{~F}+{ }^{3} \mathrm{O}_{2} \rightarrow{ }^{0} \mathrm{~F}+{ }^{1} \mathrm{O}_{2} \\
& { }^{1} \mathrm{O}_{2}+\mathrm{Sub} \rightarrow \text { Sub-OO }
\end{aligned}
$$




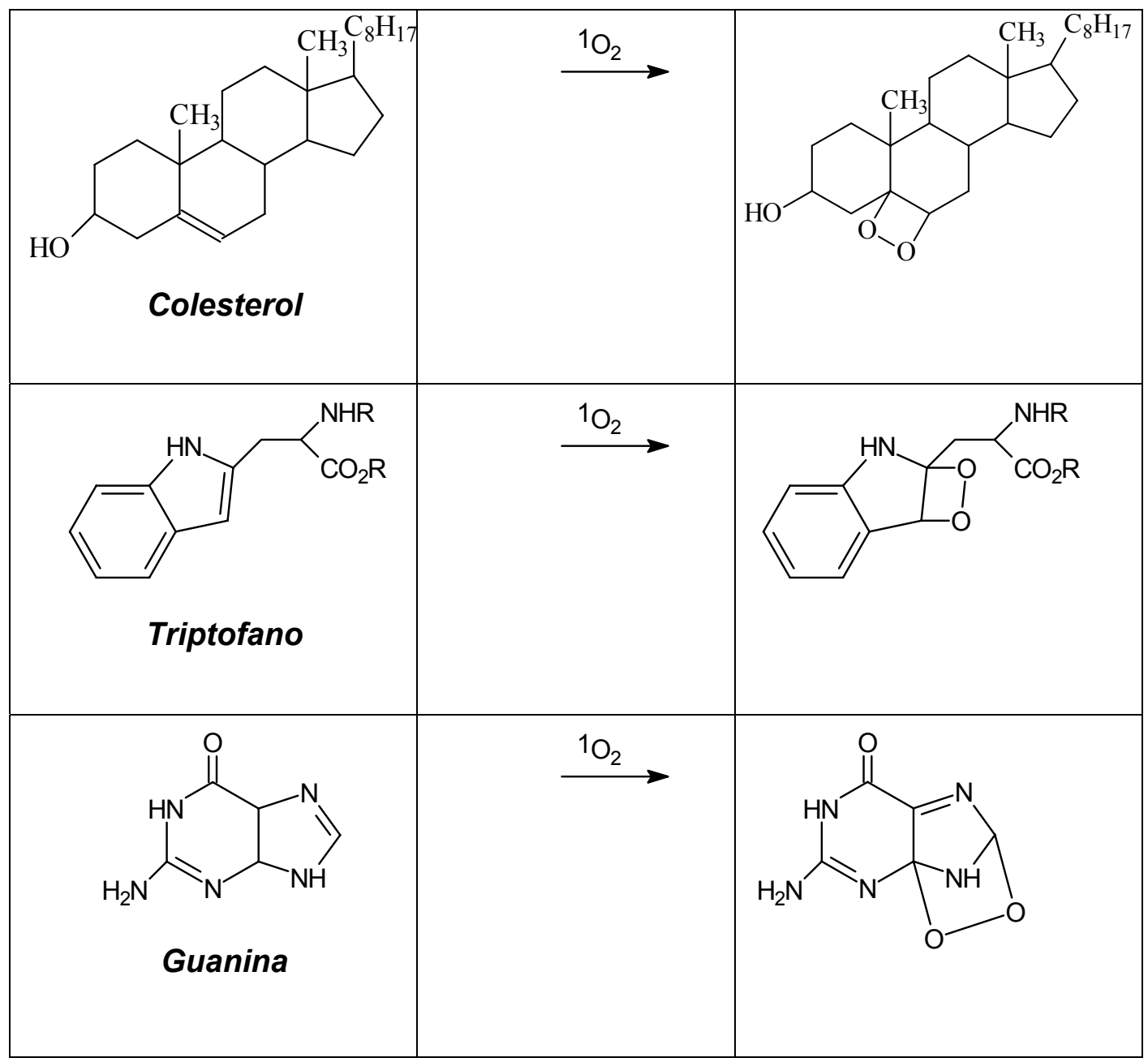

Figura 4: Reação do oxigênio singlete com grupos de moléculas importantes.

Em solução homogênea, a probabilidade e a eficiência do processo de fotossensibilização, dependem de vários parâmetros fotofísicos, tais como o rendimento quântico de produção do estado excitado tripleto e sua velocidade de decaimento para o estado fundamental. Contudo, em meio micro-heterogêneo tais como células e tecidos, os parâmetros estruturais e funcionais também estão envolvidos na determinação da eficiência do processo de fotossensibilização. Estes parâmetros regulam a incorporação, localização e a ligação/interação das moléculas do agente fotossensível com as moléculas alvo (REGAN \& PARRISH; 1982, BONNETT, 2000).

O primeiro passo no processo de fotossensibilização de uma célula é a ligação do agente fotossensível às membranas plasmáticas ou sua permeação através das mesmas para o citosol. Em princípio, a permeação pode ocorrer por difusão, por um 
sistema de transporte ativo ou por endocitose. Os processos passivos, tais como a difusão e a osmose, resultam das diferenças de concentração das substâncias dentro e fora das células, isto é, o movimento de uma substância para um gradiente de menor concentração. Os processos de transporte ativo envolvem o movimento de substâncias através de uma membrana celular contra um gradiente de potencial. Este processo usualmente envolve o uso de sistemas carreadores de drogas (BONNETT, 2000; REGAN \& PARRISH, 1982).

\subsection{Agentes fotossensíveis}

A importância da localização dos agentes fotossensíveis numa célula ou tecido se deve ao efeito produzido pela TFD nestas células. Para facilitar o desenvolvimento de novas drogas é extremamente necessário conhecer o alvo a ser destruído. Assim, um estudo sistemático da relação estrutura/atividade pode trazer melhoramentos nos procedimentos terapêuticos, visto a possibilidade de se desenvolver fármacos com afinidades por diferentes células, tecidos ou órgãos. À medida que novas drogas vêm surgindo, estudos de localização em tecidos ou a nível subcelular podem ocorrer. Alguns agentes fotossensíveis têm sido criados para emprego na sua forma pura, não em misturas. Neste sentido, mitocôndrias, lisossomos, membranas plasmáticas, ácidos nucléicos de células tumorais têm se tornado alvo potencial para a TFD (DOUGHERTY et al., 1998).

Em 1913, Meyer-Betz (MEYER-BETZ, 1913) desenvolveu testes cutâneos de fototoxicidade injetando hematoporfirina em si mesmo a fim de avaliar o efeito fotosensibilizante em humanos. A autofluorescência tumoral, devido ao acúmulo de porfirina endógena em tumores experimentais foi demonstrado por Policard, em 1924, ao utilizar uma lâmpada de Wood. A Lâmpada de Wood é uma lâmpada com uma luz azulada que auxilia no diagnóstico das micoses superficiais. Quando há a presença de tinha, a luz azulada torna-se esverdeada; na presença de pitiríase versicolor, podese visualizar uma coloração róseo-dourada. A porfiria apresenta urina avermelhada, que com a lâmpada de Wood evidencia-se cor alaranjada, sendo esta lâmpada capaz de fotoestimular corantes biológicos, evidenciando algumas patologias (POLICARD, 1924).

Auler e Banzer (AULER \& BANZER, 1942) usaram a hematoporfirina para 
destruição seletiva de tumores em animais. O derivado da hematoporfirina foi isolado por Schwartz ao reagir ácido acético glacial e ácido sulfúrico com hematoporfirina e posterior solubilização álcali diluído. O derivado da hematoporfirina, para a localização tumoral, apresentou melhores propriedades que a hematoporfirina e foi utilizado com sucesso por Lipson em 1961 (DANIEL, 1991). Dougherty e colaboradores (DOUGHERTY et al., 1975) usaram o termo terapia de fotorradiação para descrever o tratamento de tumores em animais, usando luz visível filtrada e um derivado da hematoporfirina.

A primeira grande série de pacientes que passou pela terapia fotodinâmica usando-se um derivado da hematoporfirina foi relatada por Dougherty e seus colaboradores no ano de 1977, onde 111 dos 113 casos de tumores malignos em 25 pacientes, sofreram uma redução volumétrica parcial ou completa do tumor (DOUGHERTY, 1998).

Até meados de 1994, quase todas as aplicações clínicas de TFD utilizavam alguma substância química derivada da hematoporfirina (HpD), como agente fotossensível (JORI, 1994). Atualmente, dentre as várias classes de agentes fotossensíveis disponíveis, destacam-se também os derivados de xantenos e as ftalocianinas (SHARMAN et al., 1999). No presente trabalho foram utilizados corantes representantes destas três diferentes classes, conforme mostrado na Figura 5, respectivamente.

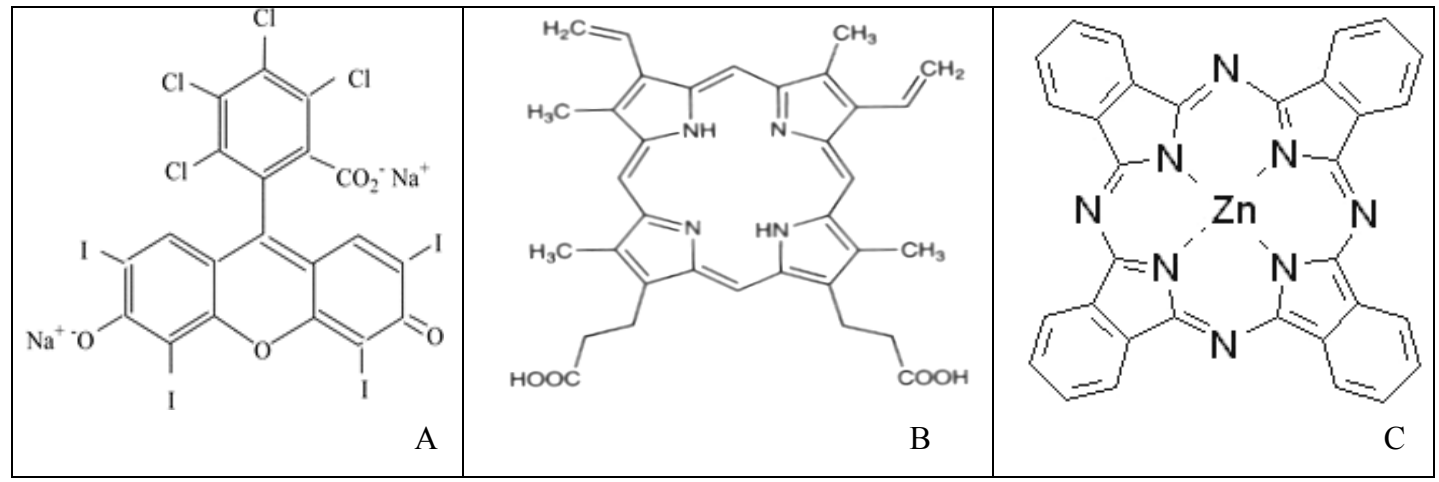

Figura 5: Estrutura química do Rose bengal (A), Protoporfirina IX (B) e Zinco Ftalocianina (C).

Os derivados de xanteno são comumente utilizados como marcadores auxiliares de trauma corneano (BOWYER et al., 2001), apesar de não serem utilizados na TFD clínica e apenas empregados como modelos experimentais comparativos. Apresentam excelentes propriedades fotofísicas e uma boa produção de oxigênio singlete (KOCHEVAR et al., 1996). Dentre estes derivados, o Rose bengal 
$(\mathrm{RB})$, Figura $5 \mathrm{~A}$, revelou ser um bom produtor de oxigênio singlete quando utilizado como agente fotossensível apresentando uma absorção de luz na região de $500 \mathrm{~nm}$ (PACZKOWSKI et al., 1985). Além disso, estudos pré-clinicos já demonstraram que, em doses adequadas de droga e luz, o Rose bengal pode ser utilizado com segurança no tratamento de desordens da pele (WATCHTER et al., 2003).

Um outro agente fotossensível endógeno, a Protoporfirina IX (PPIX) (Figura 5 B) (MACDONALD et al., 2001), penúltimo produto da biosíntese do grupo Heme, é um composto aromático planar, derivado da porfirina, constituída por quatro unidades pirrólicas arranjadas simetricamente e ligadas umas as outras por pontes metina. São completamente conjugadas, garantindo assim uma forte banda de absorção no espectro do visível, em aproximadamente $400 \mathrm{~nm}$, denominada Banda Soret. Além disso, as porfirinas e seus derivados têm sido efetivos na inativação de bactérias Gram positivas como Streptococcus faecalis e Staphylococcus aureus (SZOCS et al., 1999).

A Protoporfirina IX em seu estado basal é uma molécula no estado singlete $\left(S_{\circ}\right)$ que quando irradiada pode dependendo da quantidade de energia absorvida, passar por um cruzamento intersistemas (ISC), produzindo uma molécula de Protoporfirina IX no estado triplete. $\mathrm{O}$ oxigênio molecular, estando em seu estado triplete basal $\left({ }^{3} \mathrm{O}_{2}\right)$, serve como um bom receptor de energia de moléculas no estado triplete (como é o caso da Protoporfirina IX). Assim, esta transferência de energia é favorável, permitindo a formação de uma nova espécie reativa, o oxigênio singlete $\left({ }^{1} \mathrm{O}_{2}\right)$ (ERICSON et al., 2003).

As propriedades fotofísicas das ftalocianinas são fortemente dependentes do íon do metal central e, entre as ftalocianinas metálicas, a zinco (II) (complexo zinco ftalocianina) (ZnPc) e o Alumínio (III) (complexo de cloroalumínio ftalocianina) apresentam favoráveis propriedades fotofísicas para aplicações em TFD, com estado singleto excitado de uma relativa longa vida ( $3-8 \mathrm{~ns}$ ) e estado tripleto, também com um tempo de vida longo, são formados (NUNES et al., 2004). A coloração intensa das ftalocianinas, juntamente com sua estabilidade térmica, levaram esta classe de compostos a serem utilizados em diversas áreas, como o seu emprego como corantes na pigmentação de plásticos, o uso em fotografia colorida, além de poderem ser utilizadas como sondas de diagnóstico para tumores.

A Zinco Ftalocianina (Figura 5C) é um promissor agente fotossensibilizador de segunda geração muito utilizado na TFD, visto sua aumentada eficiência na produção 
de oxigênio singlete (SIBATA et al., 2004; OLIVEIRA et al., 2005). Este corante, insolúvel em meio aquoso, exibe um forte espectro na região do vermelho com um comprimento de onda máximo em $671 \mathrm{~nm}$.

Alguns derivados de ftalocianinas apresentam baixa solubilidade em solução aquosa, necessitando de técnicas alternativas, como a sua incorporação a sistemas carreadores de drogas, para que a disponibilidade destas drogas a sistemas celulares seja realizada (SIBATA et al., 2004; OLIVEIRA et al., 2005).

\subsection{A fonte de luz}

Segundo Tomé, a terapia fotodinâmica tem aplicação moderadamente complexa porque requer não só a dose certa da substância fotossensibilizadora como também a dose certa de luz para a sua ativação (TOMÉ, 2002). De acordo com Jacques e colaboradores, cada mol de um determinado tipo de porfirina deve receber uma determinada quantidade de fótons para que possa transferir energia para o oxigênio tripleto e iniciar o efeito citotóxico. Portanto é necessário um fornecimento de luz adequado para o sucesso da terapia (JACQUES et al., 1992).

Assim, a fonte luminosa precisa ter a capacidade de gerar luz com comprimento de onda adequado e com suficiente intensidade para ativar 0 fotossensibilizador, além do que esta fonte precisa ser móvel e dirigível para que apenas a área alvo seja iluminada.

Embora a maioria das aplicações da TFD esteja associada à luz laser, fontes de luz não laser têm sido empregadas. (BRANCALEON \& MOSELEY, 2002). Além disso, estudos desenvolvidos na última década indicam claramente que o uso de luz visível isolada de um fotopolimerizador de resina odontológica não induz nenhum dano térmico ou fotoquímico à retina (SATROM et al., 1987). Quanto ao operador ou ao paciente, não há nenhum tipo de dano aos olhos devido à irradiação UV-A ou UV-B provenientes do próprio equipamento, pelo fato destas potências neste comprimento de onda serem baixas. Quanto ao custo dos fotopolimerizadores de resina odontológica, estes apresentam ser inferiores aos laseres disponíveis no mercado (COOK, 1986).

\subsection{Efeitos da TFD}


Os efeitos da TFD são conseguidos através de uma série de eventos fotofísicos oriundos da excitação do agente fotossensível pela luz, os quais levam à produção de espécies reativas de oxigênio (basicamente oxigênio singlete), que iniciam uma série de eventos citotóxicos, induzindo danos a todos os componentes celulares com a conseqüente morte da célula (COHEN et al., 1974; ROSS et al., 1977; BRASSEUR et al., 1988; PENNING \& DUBBELMAN, 1994).

Devido à limitada migração do oxigênio singlete de seu local de origem ao sítio de ação, as regiões de localização dos agentes fotossensíveis estão proximamente relacionadas com a região de ação da TFD. Até 1998, os agentes fotossensíveis mais seletivos eram, para lisossomas, a Lisil-clorina-p6, para membranas celulares as porfirinas monocatiônicas e para as mitocôndiras os monômeros de porficeno. Agentes fotossensíveis que não eram captados pelas células como a uroporfirina são extremamente ineficientes. Apesar disso, estes compostos apresentam alta produção de oxigênio singlete. $O$ fato da maioria dos agentes fotossensíveis não se acumularem no núcleo das células faz com que a TFD tenha geralmente um baixo potencial causador de danos no DNA que leve a célula a mecanismos de mutação e/ou carcinogênese. Agentes fotossensíveis que se localizam na mitocôndria (ex.: ácido aminolevulínico - ALA, precursor da protoporfirina IX), são extremamente capazes de induzir a apoptose, enquanto que outros agentes localizados na membrana plasmática facilmente causam necrose após durante a exposição à luz (DOUGHERTY et al., 1998).

Foi determinado através de estudos bioquímicos que enzimas (monoamino oxidase e adenilato quinase) podem ser inativadas de maneira dose dependente e luz dependente de forma temporária ou definitiva pela TFD, utilizando como agente fotossensível o Photofrin, que é um derivado porfirínico de $1^{\text {a }}$ geração (MURANT et al., 1987).

O estudo da inativação de outras enzimas pela TFD, associado a outros métodos terapêuticos como a hipertermia, mostra uma situação bastante curiosa, onde certas enzimas são mais facilmente desnaturadas pela hipertermia após TFD (como a gliceraldeído-3-fosfato desidrogenase, uma enzima chave da via glicolítica), outras são insensíveis (como a amilase) e outras ainda são protegidas da desnaturação pela hipertermia pós TFD como a mioglobina (PRINSZE et al., 1991). 
Em se tratando de estudos da TFD sobre microrganismos, Shawar e Cooper (1990) relataram a importância da concentração da droga, sua absorção e sua relação com a fotossensibilidade de Bacillus subtilis e Streptococcus faecalis, empregando um derivado de hematoporfirina como agente fotossensível e irradiando as células com luz visível no espectro do vermelho ( $\lambda=630 \mathrm{~nm}$ ). Os estudos cinéticos conduzidos por esses autores mostram que a quantidade de droga ligada às células aumenta na medida em que sua concentração se eleva na mistura de incubação, provavelmente devido à saturação dos sítios de ligação da droga (SHAWAR \& COOPER, 1990).

As respostas celulares de procariotos à fotossensibilização são também importantes, particularmente, pelo fato do emprego da fotossensibilização no tratamento de infecções microbianas. Estudos específicos indicam que certas bactérias orais incluindo Streptococcus mutans e Streptococcus sobrinus, entre outras, podem ser inativadas após TFD com azul de toluidina e azul de metileno (WILSON et al., 1993), alumínio ftalocianina dissulfonada (BURNS et al., 1995) ou Rose Bengal (PAULINO et al., 2005).

Soukos e colaboradores mostraram que o azul de toluidina é citotóxico para $S$. sobrinus em concentrações ao redor de 5,0 $\mu \mathrm{g} / \mathrm{mL}$ após irradiação com luz lazer de baixa energia (7,3 $\mathrm{mW}$ em laser de Hélio-Neônio), enquanto que o tratamento similar não afetou a viabilidade de queratinócitos orais, sugerindo que o sistema de TFD pode ser empregado eficazmente no combate a bactérias causadoras de doenças periodontais (SOUKOS et al., 1996). Também nesse sentido, Wood e colaboradores elaboraram um estudo in vitro para testar a TFD (com luz laser) não em uma bactéria isolada, mas no ecossistema representado pelo biofilme dental, empregando para isso um sistema removível implantado no dente de voluntários, que permitiu o estabelecimento de um biofilme. Após um tempo determinado, esse sistema era removido e submetido à TFD com ftalocianina. Os resultados mostrados por esses autores incluem a ocorrência de danos à membrana das bactérias e vacuolação do citoplasma, indicando que a TFD causou sérios danos para a estrutura bacteriana, sendo um potencial agente no combate a esses microrganismos (WOOD et al., 1999).

O'Neil e colaboradores (2003), a fim de estabelecer comparativamente a eficácia entre agentes fotossensibilizadores atualmente empregados, investigaram a ação fotodinâmica de seis diferentes corantes contra $S$. sanguis, usando um laser de Hélio-neônio (632,8 nm). 
O uso de corantes derivados de porfirinas (SHAWAR \& COOPER, 1990; MEULEN et al., 1997; ROVALDI et al., 2000) e ftalocianinas (WOOD et al., 1999) tem sido comprovadamente eficiente no controle de microrganismos Gram positivos, dentre os quais está incluso o S. mutans.

O desenvolvimento da TFD voltado para a inativação de bactérias tem sido motivado pela observação do surgimento nos últimos anos, de linhagens de bactérias altamente resistentes a antibióticos. Diversas investigações têm estabelecido que bactérias Gram positivas sejam sensíveis à ação fotossensibilizante de uma ampla variedade de porfirinas e ftalocianinas. Por outro lado, bactérias Gram negativas possuem uma considerável resistência à fotossensitização, a não ser que seja aumentada a permeabilidade de sua membrana externa pelo tratamento anterior com agentes químicos ou biológicos tais como $\mathrm{CaCl}_{2}$ ou Tris-EDTA (VENEZIO et al., 1985; SHAWAR \& COOPER, 1990).

\subsubsection{Mecanismos da TFD em microrganismos}

Microrganismos têm desenvolvido efetivas estratégias para otimizar suas condições de crescimento e sobrevivência. Bactérias têm se adaptado a uma variedade de formas de resistência ao estresse oxidativo e danos oriundos de um mundo predominantemente aeróbico. A ocorrência quase que universal de mecanismos de resistência contra estresse oxidativo, particularmente os provenientes de espécies reativas de oxigênio (ERO's), sugerem que a maioria, se não todas as bactérias, têm que lidar com um ataque oxidativo. A fonte primária do estresse oxidativo é o metabolismo aeróbio que leva à produção de ERO's como o peróxido de hidrogênio, radical superóxido, radical peridroxil, radical hidroxil e uma variedade de outros metabólitos tóxicos, incluindo peróxidos orgânicos e outros compostos orgânicos e inorgânicos capazes de transferir elétrons para regiões de dano oxidativo. Microrganismos anaeróbicos, aeróbicos e inclusive os anaeróbios facultativos estão sujeitos ao estresse oxidativo freqüentemente como resultado de seus próprios metabólitos provenientes ou associados ao oxigênio. Dentre as maiores fontes de estresse oxidativo atuantes contra os microrganismos, destacam-se os agentes de esterilização e desinfecção utilizados na indústria como o hipoclorito, peróxido de hidrogênio entre outros (MARQUIS, 2004). 
Algumas proteínas necessárias à manutenção da integridade do DNA, à fidelidade transcricional, à eficiência traducional e ao "folding" de proteínas (Chaperoninas), são unicamente identificadas durante o crescimento ácido tolerante de Streptococcus mutans em pH 5,0 ou quando estas células crescem em pH superior a 7,0 (LEN et al., 2004). Estas proteínas, denominadas de Heat Shock Protein (HSP) são conhecidas e sua expressão também se dá em organismos Gram negativos como a Porphyromonas gingivalis (LEKE et al., 1999).

Assim, o estudo das HSP frente à TFD é importante uma vez que cepas de $S$. mutans, quando submetidas à terapia, poderiam desenvolver mecanismos de resistência ou tolerância ao contato com espécies reativas de oxigênio produzidas.

\subsection{Lipossomos}

Lipossomos são potenciais sistemas de liberação para uma variedade de compostos que incluem moléculas de baixo peso molecular como fármacos (inclusive agentes fotossensíveis), proteínas terapêuticas e agentes para diagnóstico. Eles são espontaneamente formados quando fosfolipídeos são dispostos em meio aquoso e, quando isto acontece, deve-se à interação hidrofílica da cabeça polar dos grupos fosfato com a água, resultando na formação de sistemas multilamelares. Já os sistemas unilamelares (vesículas) consistem em simples bicamadas lipídicas (Figura 6) em forma esférica, que são parecidas (mimetizam) com membranas biológicas cuja formação se dá a partir do fornecimento de energia aos sistemas multilamelares (como por exemplo, sonicação ou extrusão).

Uma variedade de fosfolipídios naturais e sintéticos está disponível para a preparação de lipossomos e são considerados como bons sistemas carreadores de drogas (VERMURI \& RHODES, 1995). 


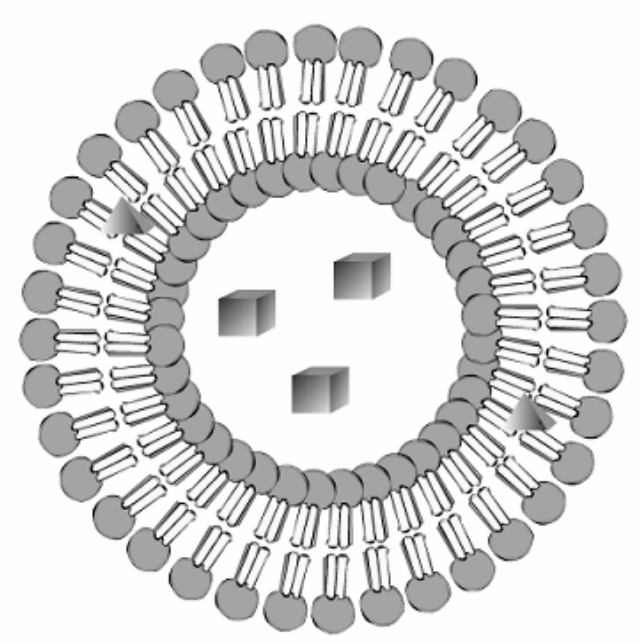

Fosfolipídeo

Substância Lipofilica

Substância hidrofilica

Figura 6: Lipossomo: representação de uma vesícula unilamelar cuja fase aquosa é inteiramente cercada por uma membrana formada por moléculas de fosfolipídeos, constituindo uma bicamada lipídica.

Embora a TFD esteja sendo usada com sucesso em diversas aplicações clínicas, seu mecanismo de ação sobre microrganismos patogênicos ainda é pouco esclarecedor, além do que, a utilização de lipossomos como modelos que permitam mimetizar situações específicas ocorridas in vivo ou seu uso como sistemas carreadores é bastante promissor. Assim, os resultados destes estudos são de importância na pesquisa de novos agentes fotossensíveis a fim de melhorar a eficiência da TFD (inclusive utilizando-os como carreadores) e o entendimento dos efeitos citotóxicos de algumas drogas (HOEBEKE, 1995). 


\section{OBJETIVOS:}

O presente projeto teve como objetivo a padonização e adequação de um método capaz de promover o controle da bactéria Streptococcus mutans, utilizada como modelo biológico, através do emprego da terapia fotodinâmica, auxiliada pelo emprego de uma luz não laser onde os corantes são carreados por sistemas homogêneos ou micro heterogêneos de lipossomos.

A cárie dental hoje pode ser considerada uma doença de ocorrência mundial, em especial nos países subdesenvolvidos, o que leva a gastos enormes com o tratamento de suas conseqüências, fazendo com que sejam necessárias a tomada de medidas preventivas e/ou curativas com menores gastos. Assim, no presente projeto foi estudada a TFD associada a diferentes agentes fotossensíveis sobre o crescimento da bactéria Streptococcus mutans, devido à sua estreita relação com a cárie e por ser um dos principais organismos responsáveis pelo processo cariogênico.

Apesar da utilização da TFD no tratamento antimicrobiano estar ainda em recente estágio de desenvolvimento, esta técnica parece ser muito promissora, em função do surgimento de microrganismos cada vez mais resistentes a antibióticos disponíveis (MEULEN et al., 1997).

O projeto engloba estudos bioquímicos visando a utilização de corantes fotossensíveis compreendendo os seguintes objetivos específicos:

- Padronização de condições ótimas de cultivo de Streptococcus mutans;

- Definição da luz fotoativadora e da(s) droga(s) ideal(is) para o estudo da TFD em S. mutans;

- Caracterização fotofísica dos corantes empregados;

- Identificação do tempo ideal de incubação das drogas "in vitro";

- Determinação da localização e quantificação do corante na célula;

- Avaliação do efeito do corante sobre o crescimento de S. mutans com e sem irradiação;

- Avaliação do efeito do corante em sistemas de lipossomos, com e sem irradiação;

- Otimização das condições de concentração de corante, potência e tempo de irradiação com luz fotoativadora sobre as células e/ou sistemas de 
lipossomos;

- Estudo da toxicidade dos agentes fotossensíveis em células bucais;

- Estudos da alteração da capacidade acidogênica da S. mutans após a TFD;

- Avaliação da TFD sobre o biofilme formado por S. mutans;

- Avaliação dos danos provocados pela TFD sobre o DNA bacteriano;

- Avaliação da expressão de Heat shock protein (HSP) por S. mutans após TFD. 


\section{MATERIAL E MÉTODOS}

\subsection{Equipamentos utilizados}

- Analisador de espalhamento dinâmico da luz: Zetasizer $3000 \mathrm{HS}_{\mathrm{A}}$, da Malvern Instruments Ltda

- Bomba peristáltica: Pump P-1, Pharmacia Biotech

- Câmara de Neubauer

- Centrífuga: RC-5, Superspeed Refrigerated Centriguge, Sorval

- Coletor de Frações: Spectrum/Chrom - CF1 Fraction Collector

- Contador de colônias: Phoenix Ind. E Com. Equip. Científicos Ltda Araraquara - Brasil

- Espectrofluorímetro: Spectronic SLM 8100

- Espectrofluorímetros: modelo F-4500 da Hitachi e Fluorog 3 da SpexAs

- Espectrofotômetro: Milton Roy, Spectronic, Genesys 2

- Espectrofotômetros de absorção, modelo U-3000 da Hitachi e Lambda 20 da Perkin Elmer

- Estereomicroscópio: Leica; modelo MZ FLIII

- Estufa Microbiológica: Quimis, Modelo Q316B14

- Fotopolimerizador de Resina Odontológica: Dabi Atlante, Modelo Ultralux (Figura 7)

- Gradiente Maker: SG 100, Hoefer

- Leitor Placa de ELISA: Labsystem

- Osmose Reversa com deionizador: Millipore, modelo Direct-Q

- pHmetro: Marte, Modelo MB10

- Sistema de detecção de luz: Power Meter da Field Master, Coherent, com uma cabeça de detecção LM-30V

- Sistema purificador de água: Direct-Q, Millipore

- Sonicador de Ponta: Sonics \& Materials, modelo Vibra Cell VC 600

- Ultracentrífuga: Hitachi, Himac 70 MX 


\subsection{Material utilizado}

Todas as soluções aquosas foram preparadas com água ultrapura, obtida através do sistema Direct-Q (Millipore), com uma filtragem final em membrana de $0,22 \mu \mathrm{m}$ de diâmetro.

Os reagentes com grau de pureza analítico abaixo relacionados foram adquiridos dos respectivos fabricantes e empregados nos experimentos:

Corning Star: Placa de cultura de 24-wells - 3524;

Difco: Triptic Soy Broth (TSB); Tryptic Soy Agar, Difco (TSA); Doles Reagentes: Kit para dosagem de glicose - Glucox 500;

Gibco: Soro Bovino fetal (BSA); Hank's Balanced Salt Solution (HBSS); Meio Dulbecco's Modified Eagle /Medium F-12 Nutrient medium (DMEN/F1); Dodecil sulfato de sódio (SDS); Membrana de nitrocelulose; Ditiotreitol (DTT);

Merck: Ácido clorídrico; Ácido sulfúrico; Azul Tripan; Cloreto de potássio; Cloreto de sódio; Fluoreto de sódio; Clorofórmio, Dimetilsulfóxido (DMSO); Dimetilformamida (DMF); Frutose; Glicose; Maltose, 3-(4,5-dimetil tiazol-2-il)-2,5difenil brometo de tetrazolina (MTT); Piridina; Xilose; Metanol; n-butanol; Isopropanol; Sacarose; Sulfato de magnésio; Ácido tricloroacético (TCA); Tiocianato de sódio; Uréia.

Mallinckodt: Fosfato de potássio monobásico; Fosfato de sódio dibásico;

Millipore: Membrana estéril de 0,22 $\mu \mathrm{m}$;

Sigma: Acrilamida; anticorpo de cabra anti-IgG; Anti-GroEL; Bis acrilamida; Soro Albumina bovina (BSA); Cloranfenicol; 3,3'-Diaminobenzina (DAB); Coquetel de inibidor de proteases P-8465; Dipalmitoilfostatidilcolina (DPPC); DNAase; Glass Beads G8772; Glicerol; Placa de sílica para TLC código Z12,271-8; Protoporfirina IX (PPIX); Rose bengal (RB); Igepal CA-630; Lisofosfatidil colina (LPC); Lisozima; Ácido 2-[N-Morfolino]etanosulfônico (MES); Ácido 3-[NMorfolino]propanosulfonico (MOPS); Tris (hidroximetil)-aminometano (TRIS);

Tween 20; Zinco ftalocianina $(\mathrm{ZnPc})$,

Synth: Orcinol;

Os demais reagentes não mencionados foram adquiridos no mercado nacional e são de alto grau analítico (PA). 


\subsection{Streptococcus mutans}

\subsubsection{Padronização das condições de crescimento de Streptococcus mutans em meio líquido}

A cepa ATCC 25175 de Streptococcus mutans, adquirida da Fundação André Tosello, foi armazenada $\left(-20^{\circ} \mathrm{C}\right)$ em uma solução $40 \%(\mathrm{v} / \mathrm{v})$ de glicerol e sua pureza checada antes do uso através de um inóculo em meio de crescimento. Para cultivar e avaliar a pureza da bactéria foram utilizados os meios de cultivo TSB ou o TSA e preparados de acordo com as instruções do próprio fabricante. Para os demais testes de crescimento bacteriano na presença de diferentes fontes de carbono foi empregado o meio completo, descrito por Dhasper e Reynolds (DHASPER \& REYNOLDS, 1991). Todos os materiais, carboidratos e meios de cultivo foram autoclavados a $121^{\circ} \mathrm{C}$ durante 20 minutos antes do uso. Os cultivos foram efetuados em uma jarra de anaerobiose (técnica da vela), a fim de produzir um ambiente favorável ao crescimento do microrganismo. Para o preparo do inóculo de $S$. mutans, a turbidêz inicial das bactérias foi avaliada em um espectrofotômetro e ajustada inicialmente para $A_{600 n m}=0,5$. Para a determinação da contagem dos microrganismos viáveis em meio líquido, $15 \mu \mathrm{L}$ de uma suspensão celular $\left(A_{600 n m}=0,5\right)$ foi inoculada em tubos contendo $4 \mathrm{~mL}$ do meio de cultivo (TSB ou Meio completo) e a contagem inicial de unidades formadoras de colônia por mililitro de suspensão celular (UFC/mL) foi estimada, após o cultivo das células, através da contagem realizada em um contador de colônias conforme descrito por Paulino e colaboradores (PAULINO et al., 2005).

\subsubsection{Avaliação do consumo de carboidratos durante o crescimento de $S$. mutans}

Os carboidratos consumidos durante o crescimento de S. mutans foram avaliados por cromatografia em camada delgada (TLC) e, especificamente a glicose, por método enzimático.

A placa de sílica para TLC utilizada $(20 \times 20 \mathrm{~cm})$ foi ativada a $100^{\circ} \mathrm{C}$ durante 2 
horas. $0,5 \mathrm{~mL}$ de TCA $30 \%(\mathrm{p} / \mathrm{v})$ foi adicionado às alíquotas $(1 \mathrm{~mL})$ do meio (livre de células) onde foi realizado o cultivo e em seguida, misturado em vórtex por 1 minuto. Esta solução foi mantida a $4^{\circ} \mathrm{C}$ por 12 horas, ocorrendo assim uma preciptação das proteínas presentes no meio de cultivo. Após este período, as amostras foram centrifugadas (3.000xg durante 15 minutos) e $50 \mu \mathrm{L}$ do sobrenadante foram concentrados (10 vezes) por secagem em sistema de vácuo para posteriormente ser aplicado na placa de TLC.

Como padrão, $3 \mu \mathrm{L}$ de glicose ou de xilose $(50 \mathrm{mg} / \mathrm{mL})$ ou de uma mistura destes dois carboidratos $(25 \mathrm{mg} / \mathrm{mL}$ de cada) foram aplicados à placa. A fase móvel foi constituída por n-butanol:piridina:água:metanol numa proporção de 7:3:1:0,45 $(v / v)$. Após a corrida cromatográfica, a placa foi seca à temperatura ambiente em capela de exaustão e em seguida pulverizada com uma solução de Orcinol 0,2\% $(p / v)$ em ácido sulfúrico/metanol $(1: 1, v / v)$. A revelação da cromatografia ocorreu em uma estufa a $150^{\circ} \mathrm{C}$ durante aproximadamente 5 a 10 minutos conforme descrito em Paulino e colaboradores (PAULINO et al., 2003). As imagens foram posteriormente capturadas em um scanner.

Para a dosagem enzimática de glicose, foi utilizado um kit (Glucox 500). A glicose foi avaliada quantitativamente no meio de cultivo durante diferentes fases do crescimento da bactéria e para isto uma curva padrão foi construída com crescentes quantidades de glicose $(0,05-0,5 \mathrm{mg} / \mathrm{mL})$ e utilizada para determinar o fator de conversão (Absorbância em $510 \mathrm{~nm}$ por $\mu$ g de glicose) onde a presença de xilose não afetou a determinação da glicose por este método.

\subsubsection{Determinação do número de Unidades Formadoras de Colônias (UFC's)}

Para a determinação do número de UFC's da suspensão bacteriana utilizada nos experimentos foi empregada a técnica da semeadura em placa (Spread Plate). Assim, após a realização de cada experimento, as células foram espalhadas (50 $\mu \mathrm{L} /$ placa) com o auxílio de uma alça de Drigalski sobre a placa contendo meio de cultivo (TSA). Posteriormente foram incubadas, a $37^{\circ} \mathrm{C}$ em microanaerobiose, durante 48 horas para determinação da contagem das UFC's. 


\subsubsection{Avaliação do pH e densidade óptica do meio de cultivo durante o crescimento de $S$. mutans}

Durante o crescimento da bactéria, para a realização de curvas de crescimento, a densidade óptica e o pH do meio foram avaliados (a cada 2 horas) coletando-se para análise alíquotas $(2 \mathrm{~mL})$ do meio de cultivo previamente homogeneizado.

\subsubsection{Padronização do crescimento do biofilme de $S$. mutans}

Para se avaliar as melhores condições de crescimento para o biofilme (carboidrato e inoculo), o meio completo, descrito por Dhasper e Reynolds (DHASPER \& REYNOLDS, 1991), foi previamente autoclavado e usado nos experimentos com o biofilme.

Cada solução estoque dos açucares (glicose, xilose, sacarose (2 mol/L) e maltose $(1 \mathrm{~mol} / \mathrm{L}))$, previamente autoclavada, foi utilizada para complementar o meio de cultivo. Todos os cultivos ocorreram numa jarra de anaerobiose a $37^{\circ} \mathrm{C}$ durante 12 horas.

A bactéria estoque foi submetida a três transferências sucessivas, a cada 24 horas de intervalo em meio TSB, a fim de restabelecer o metabolismo bacteriano normal.

A turbidêz das células utilizadas como pré-inóculo para o experimento foi ajustada para $A_{600 n m}=0,5$. Para a formação do biofilme o meio líquido completo foi suplementado com os carboidratos (1\% p/v, concentração final) e distribuídos (1 $\mathrm{mL} /$ poço) em uma placa de cultura de 24-poços. Foi inoculado em cada poço $15 \mu \mathrm{L}$ do pré-inóculo $\left(\mathrm{Abs}_{600 \mathrm{~nm}}=0,5\right)$ para posteriormente ser incubado durante 12 horas, conforme descrito por Paulino e colaboradores (PAULINO et al., 2003). Após este período, o meio de crescimento foi removido e cada "poço" foi lavado com PBS ( $\mathrm{NaCl} 0,13 \mathrm{~mol} / \mathrm{L}, \mathrm{KCl}$ 2,7 mmol/L, $\mathrm{Na}_{2} \mathrm{HPO}_{4} 8,1 \mathrm{~mol} / \mathrm{L}$ e $\mathrm{KH}_{2} \mathrm{PO}_{4}$ 1,47 mol/L pH final de 7,5), seco a temperatura ambiente e as imagens foram capturadas através de um estereomicroscópio. 


\subsubsection{Padronização das condições de crescimento de $S$. mutans na placa de 24 poços (formação do biofilme)}

Uma curva de crescimento do biofilme foi realizada para avaliação da melhor condição de tempo de cultivo a ser adotado para o cultivo do biofilme de $S$. mutans em meio completo, suplementado com sacarose $(1 \%, \mathrm{p} / \mathrm{v})$. Assim, em uma placa de 24 poço foi adicionada $1 \mathrm{~mL}$ em cada poço de um inoculo que continha 3,75 $\mu \mathrm{L}$ de S. mutans $\left(\mathrm{Abs}_{600 \mathrm{~nm}}=0,5\right)$ e sacarose $1 \%(\mathrm{p} / \mathrm{v})$. Este meio de cultivo, após o inóculo, foi retirado em intervalos subseqüentes de 1 hora (4 poços/ hora). Para isso, $1 \mathrm{~mL}$ do meio de cultivo contido em cada poço foi substituído por $1 \mathrm{~mL}$ de uma solução fluoretada (NaF, 10mmol/L) que interrompeu o crescimento do biofilme nestes respectivos poçoss. Desta forma, ao final de 6 horas de curva de crescimento, uma curva, com 6 intervalos diferentes foi obtida e para cada intervalo foi obtido 4 poços contendo o biofilme formado. Estes biofilmes formados foram levados a um estereomicroscópio para serem avaliados quanto ao seu melhor tempo de crescimento onde existiam células confluentes ou não nos respectivos poços.

\subsection{Fibroblastos}

\subsubsection{Condições de crescimento dos Fibroblastos}

As cepas de fibroblastos foram obtidas a partir de uma linhagem ATCC CCL110 (PAULINO et al., 2005) e mantidas em solução estoque congeladas em nitrogênio líquido com soro bovino fetal (FBS) e DMSO (9:1 v/v). Após o processo de descongelamento, os fibroblastos foram crescidos em placas de cultivo com meio Dulbecco's Modified Eagle /Medium F-12 Nutrient medium (DMEM-F12), o qual foi preparado de acordo com as instruções do próprio fabricante, filtrado em uma membrana estéril de 0,22 $\mu \mathrm{m}$. O meio obtido é ainda enriquecido com FBS $10 \%$, penicilina $100 \mathrm{U} / \mathrm{mL}$, estreptomicina $100 \mu \mathrm{g} / \mathrm{mL}$ e anfotericina $0,25 \mu \mathrm{g} / \mathrm{mL}$.

O meio onde foram crescidas as células foi renovado duas vezes por semana e os fibroblastos foram utilizados quando todas as células estavam completamente confluentes e alcançaram uma contagem aproximada de $1 \times 10^{6}$ células $/ \mathrm{mL}$. 


\subsection{Preparação da solução estoque dos Agentes Fotossensíveis Utilizados na TFD}

\subsubsection{Preparação da solução estoque de Rose bengal}

Para os experimentos realizados foi constituída uma solução estoque de Rose bengal em tampão fosfato salino (PBS) esterilizado em um filtro de 0,22 $\mu \mathrm{m}$, resultando numa concentração final de $2 \mathrm{mmol} / \mathrm{L}$. Esta solução foi então armazenada a uma temperatura de $-20^{\circ} \mathrm{C}$ até o uso.

\subsubsection{Preparação da solução estoque de Protoprofirina IX}

Para os experimentos realizados foi constituída uma solução estoque de Protoporfirina IX $2 \mathrm{mmol} / \mathrm{L}$ em solução ácida (HCl $1 \mathrm{~mol} / \mathrm{L})$ :metanol (1:9, v/v). Esta solução foi então fracionada e armazenada a uma temperatura de $-20^{\circ} \mathrm{C}$ até o uso.

\subsubsection{Preparação da solução estoque de Zinco Ftalocianina (ZnPc)}

Para os experimentos realizados foi constituída uma solução estoque de ZnPc $\left(3,87 \times 10^{-4} \mathrm{~mol} / \mathrm{L}\right)$ em dimetilformamida:dimetilsulfóxido $(1: 1, \mathrm{v} / \mathrm{v})$. Esta solução foi então fracionada e armazenada a uma temperatura de $-20^{\circ} \mathrm{C}$ até o uso.

\subsection{Preparação dos Lipossomos e ZnPc-lipossomos}

A fim de se utilizar a $\mathrm{ZnPc}$ em meio aquoso, foram empregados os lipossomos. Estas vesículas foram preparadas por sonicação empregando-se 12,0 $\mathrm{mg}$ de DPPC e 1,2 mg de LPC os quais foram dissolvidos conjuntamente em $4 \mathrm{~mL}$ de clorofórmio. A preparação do ZnPc-lipossomo ocorreu da mesma maneira sendo o corante adicionado a fase orgânica em concentrações crescentes de até 50 $\mu \mathrm{mol} / \mathrm{L}$. Em seguida esta solução foi seca sob uma atmosfera de nitrogênio e após secagem, $4 \mathrm{~mL}$ de PBS $(\mathrm{pH} 7,4)$ foram adicionados ao filme obtido, sendo posteriormente incubado a $60^{\circ} \mathrm{C}$ durante 1 hora, com intervalos de uma vigorosa 
agitação a cada 10 minutos. Após este período de incubação, a mistura foi sonicada por 4 minutos com um sonicador de ponta (240 Watts) e ultra-centrifugada a 100.000 xg durante 20 minutos. O sobrenadante corresponde às vesículas unilamelares relativamente homogêneas, as quais foram avaliadas através de medidas de espalhamento de luz e determinação da quantidade de corante incorporado.

\subsubsection{Determinação do diâmetro médio dos lipossomos}

Para a caracterização dos lipossomos foram realizadas medidas de distribuição de tamanho de partícula por espalhamento de luz dinâmico (no momento do uso) e medidas de absorbância em 500 nanômetros para acompanhar a estabilidade da amostra durante 30 dias.

As medidas de distribuição de tamanho dos lipossomos e ZnPc-lipossomos foram realizadas empregando-se o equipamento da Malvern Instruments Ltda (modelo Zetasizer $3000 \mathrm{HS}_{\mathrm{A}}$ ) no Laboratório da Profa. Dra. Maria Elizabete Zaniquelli, no Departamento de Química da FFCLRP-USP. Para cada experimento, três seqüências de dez medidas foram realizadas.

A quantificação do corante incorporado nas vesículas lipossomais foi determinada através de medidas de absorção de luz $\left(\varepsilon_{671 \mathrm{~nm}}=2,4 \times 10^{5} \mathrm{Mol}^{-1} . \mathrm{cm}^{-1}\right)$ da amostra, utilizando-se como branco a suspensão contendo o lipossomo sozinho.

\subsubsection{Preparação do gradiente isopícnico de densidade de sacarose}

Um gradiente continuo de sacarose foi construído (1 - 30\% de sacarose em tampão PBS, com a densidade variando de 1.0381 à 1.1764) utilizando-se para a montagem do mesmo um Gradient Maker. As amostras de Zinco fitalocianina,

lipossomos e ZnPc-Lipossomos $(500 \mu \mathrm{L})$ foram aplicadas ao gradiente e centrifugadas em uma ultacentrífuga (Himac $70 \mathrm{MX}$ ) com um rotor vertical Hitachi P65VT3 a $180.000 x g$ durante 4 horas a $25^{\circ} \mathrm{C}$. Os gradientes foram fracionados com auxílio de um coletor de frações $(500 \mu \mathrm{L})$ e analisados para fosfato inorgânico conforme descrito por Chen (CHEEN et al., 1956) e para Zinco fitalocianina por fluorescência (emissão em 680 nm). 


\subsection{Caracterização fotoquímica e fotofísica dos agentes fotossensíveis estudados}

Nos estudos espectrofotométricos foram utilizados os espectrofotômetros de absorção, modelo U-3000 da Hitachi e Lambda 20 da Perkin Elmer, além dos espectrofluorímetros modelo F-4500 da Hitachi e Fluorog 3 da SpexAs. Todos os equipamentos dispõem de controle de temperatura e agitação magnética.

Para realizar a análise fotoquímica e fotofísica do $\mathrm{ZnPc}$, utilizou-se uma amostra (branco) de lipossomos sem droga (lipossomo vazio), constituídos também de DPPC:LPC, constituídos pela mesma proporção fosfolipídeos.

\subsubsection{Determinação espectroscópica de absorção no estado estacionário dos compostos fotossensíveis Protoporfirina IX e Zinco ftalocianina}

Quando uma molécula interage com a radiação eletromagnética, na faixa do ultravioleta-visível (faixa de comprimento de onda de 200-700 nm), ocorre o fenômeno denominado absorção. A espectroscopia de absorção está relacionada com a transição eletrônica das moléculas (Diagrama de Jablonski, Esquema 1) e a absorção molecular depende da estrutura eletrônica da molécula. A absorção de energia eletromagnética é quantizada e conduz à passagem de elétrons dos orbitais do estado fundamental para o estado excitado singlete de maior energia, ou seja, a radiação que é absorvida tem energia igual à diferença de energia entre os estados excitado e fundamental. Como resultado da absorção de energia, átomos ou moléculas passam de um estado de menor energia para um estado de maior energia (Esquema 1).

Os espectros de absorção UV-Visível geralmente são registrados como gráficos de Absorbância $(A)$ em função do comprimento de onda $(\lambda)$, da freqüência ou número de onda da radiação incidente. Pode-se também construir um gráfico do coeficiente de absortividade molar $(\varepsilon)$ (ou $\log \varepsilon$ ) em função de $\lambda$. As características principais de uma banda de absorção são a sua posição e sua intensidade.

A investigação dos espectros de absorção no estado estacionário da PpIX em meio homogêneo (tampão fosfato) e da ZnPC em meio lipossomal foram baseadas 
em medidas diretas dos espetros de absorção registrados de 300 a 800 nm em cela de quartzo com $1,0 \mathrm{~cm}$ de caminho óptico. As referências utilizadas nesse estudo foram tampão fosfato de sódio $(\mathrm{pH} 7,4)$ e lipossoma sem a presença do fotossenssibilizador para os espectros de solução de PpIX e lipossoma de ZnPC, respectivamente, além disso foram determinados em meios de diferentes polaridades (Tampão pH 7,4; DMSO; Acetona e Diclorometano) e os valores de coeficiente de absortividade molar $(\varepsilon)$, na presença de tampão pH 7,4 (PBS).

\subsubsection{Determinação dos espectros de emissão de fluorescência no estado estacionário dos compostos fotossensíveis estudados}

A emissão de fluorescência é um processo radioativo no qual uma molécula excitada perde a energia absorvida sob a forma de emissão de luz após a transição do estado excitado singlete para o estado fundamental (Diagrama de Jablonski, Esquema 1). A espectroscopia de emissão de fluorescência pode ser usada para se obter informações valiosas a respeito de sistemas biológicos sempre de uma maneira não destrutiva. As técnicas de fluorescência são amplamente utilizadas nos estudos de estruturas moleculares, interações entre moléculas, sondagem de meio ambientes com características diversas e análise de traços de materiais. Como vantagens, uma maior seletividade dos comprimentos de onda de excitação e emissão, maior sensibilidade de um fóton com concentração de sub-picograma de material e ampla variedade de métodos de amostragem (soluções concentradas e diluídas, superfícies sólidas, suspensões, etc).

O estudo de espectroscopia resolvida no tempo foi realizado para os compostos Protoporfirina IX e Zinco ftalocianina, nas concentrações fixas de 5 $\mu \mathrm{mol} / L$, uma vez que nestas condições estes compostos estão na forma monomérica em solução. Com base na análise dos dados espectrais de absorção, foram determinados os espectros de emissão de fluorescência, usando-se o comprimento de absorção máxima do corante PPIX (452 nm) em meio homogêneo e para o corante ZnPC (610 nm) meio lipossomal. Os espectros de emissão de fluorescência foram registrados dentro da faixa específica entre 600 a $800 \mathrm{~nm}$ para PplX em meio homogêneo e de 630 a 750 nm para ZnPC em meio lipossomal.

Para cada medida de decaimento foram coletadas em média 4000 contagens. Todas as medidas foram realizadas na presença de oxigênio (solução em equilíbrio 
com o ar) com agitação e termostatização contínuas à $25^{\circ} \mathrm{C}$.

\subsubsection{Determinação do rendimento quântico de fluorescência $\left(\Phi_{F}\right)$ dos compostos estudados}

Os rendimentos quânticos de fluorescência foram determinados utilizando como padrões violeta de cresil em etanol.

O rendimento quântico de fluorescência $\left(\Phi_{\mathrm{F}}\right)$ pode ser definido como (LAKOWICZ, 1984):

$$
\Phi_{\mathrm{F}}=\frac{n^{o} \text { de moléculas por unidadede tempoe por unidadede volume }}{n^{o} \text { de quanta absorvido por unidadede tempo por unidadede volume }}
$$

(Equação 3.1)

Essa quantidade nos informa a relação entre a quantidade de moléculas que efetivamente fluorescem $(n F)$ e de moléculas que foram eletronicamente excitadas $\left(\mathrm{N}_{\mathrm{exc}}\right)$

$$
\Phi F=\frac{n F}{N_{e x c}}
$$

O número de moléculas excitadas é, em princípio, equivalente ao número de fótons absorvidos.

Nas medidas experimentais de $\Phi_{\mathrm{F}}$ é necessário que haja uma correção prévia do espectro de emissão do material ou o uso de um padrão que apresente propriedades semelhantes às da espécie desconhecida (o espectro de emissão da amostra deve estar na mesma faixa do de emissão do padrão) (DEMAS; CROSBY, 1971). Assim, este método consiste na comparação de áreas sobre os espectros de emissão de fluorescência corrigidos de uma solução padrão e da amostra em estudo. $A$ área $A$ é dada por $A=\Phi_{F} D O$, onde $D O$ é a densidade óptica da amostra. Deste modo, o rendimento quântico foi determinado por (Equação 3.3):

$$
\phi_{\text {amostra }}=\frac{\text { Área }_{\text {padrãoo }}}{\text { Area }_{\text {amostra }}} x \frac{\text { Absorbânica }}{\text { amostra }} \times \frac{n_{\text {amostra }}}{n_{\text {padrão }}} x \phi_{\text {padrão }}
$$


Os espectros foram determinados sob as mesmas condições experimentais. As soluções do padrão e da amostra foram preparadas numa concentração que assegurasse uma absorbância de 0,1 no comprimento de onda de excitação ( $\lambda_{\text {exc }}=$ $600 \mathrm{~nm}$ para o violeta de cresil, $\lambda_{\mathrm{exc}}=577 \mathrm{~nm}$ para PPIX e $\quad \lambda_{\mathrm{exc}}=610 \mathrm{~nm}$ para $\mathrm{ZnPC})$.

Foram utilizados como padrões solução de violeta de cresil em etanol $\left(\Phi_{\mathrm{F}}=\right.$ $0,54)$ e solução de $Z n P C$ em etanol $\left(\Phi_{F}=0,28\right)$. A seguir, foi traçado o espectro de emissão corrigido de cada sistema estudado, sendo determinada a área sob as curvas (600 a 800 para PPIX e 630 a $750 \mathrm{~nm}$ para ZnPC).

\subsubsection{Determinação do espectro de absorção resolvido no tempo}

A fotólise por pulso de laser é uma técnica muito utilizada para o estudo de processos fotoquímicos primários. A técnica é muito utilizada para estudos de características de emissão e absorção de espécies transientes.

O método de fotólise por pulso de laser consiste na excitação de uma amostra por um pulso de luz de alta intensidade (luz laser) o qual é absorvido pela amostra. Nestas condições formam-se intermediários (ou espécies transientes) de vida curta como as espécies excitadas, os radicais e os íons em altas concentrações. A técnica envolve a irradiação de uma amostra com um pulso de curta duração e alta energia de uma luz laser monocromático monitorando-se as mudanças na densidade óptica das espécies presentes de $\mu \mathrm{s}$ a ms.

Esse espectro mostra a diferença entre as absorções do transiente e do precursor (estado estacionário) e podem ajudar na identificação de espécies excitadas.

A técnica de fotólise por pulso de laser possui várias vantagens como a possibilidade de ser aplicada a gases, líquidos (soluções) e sólidos, na presença ou ausência de oxigênio. Sua alta sensibilidade permite o estudo de intermediários com concentrações muito pequenas utilizando-se amostras diluídas e/ou volume pequeno nas cubetas. Além disso, a identificação de intermediários pode ser feita através do espectro se as bandas de absorção forem separadas e caracterizadas e sua investigação pode ser feita na região de nano e picosegundos. 
Entretanto, a técnica de fotólise por pulso de laser apresenta algumas limitações onde a amostra deve ser opticamente clara e transparente para o monitoramento da luz. A presença de espalhamento de partículas deve ser evitada, e a absorbância da solução deve ser ajustada de modo a aumentar a eficiência da luz de monitoramento. Seu intermediário reativo não deve possuir absortividade molar baixa. Além disso, a falta de detalhes no espectro de absorção pode tornar a identificação quase impossível e a determinação de parâmetros cinéticos pode ser difícil, especialmente para intermediários de vida muito curta.

Os principais componentes do espectrômetro para medidas de fotólise por pulso de laser são: fonte de excitação (laser), fonte de análise (usualmente uma lâmpada de Xenônio operando em modo contínuo (CW) ou pulsado), compartimento de amostra e célula de amostra, monocromador ou filtros de análise, detector de análise (usualmente um tubo de fotomultiplicadora ou fotodiodo de Silício), um registrador de transiente de alta velocidade (usualmente um osciloscópio analógico para registro dos dados) e um computador (para controle do experimento, armazenagem do sinal e processamento dos dados).

Os estados excitados triplete dos fotossenssibilizadores PPIX em meio homogêneo (tampão fosfato $\mathrm{pH} 7,4$ ) e $\mathrm{ZnPC}$ em meio lipossomal foram gerados e estudados por fotólise por pulso de laser. Os experimentos foram realizados utilizando-se como fonte de excitação o terceiro harmônico (355 nm) do laser pulsado de Nd-YAG da Continuum, modelo SURELITE I-10. Os estudos para obtenção dos decaimentos das espécies triplete geradas e os espectros de absorção dos transientes foram realizados numa concentração tal que a absorbância fosse aproximadamente 0,3 num comprimento de onda de $355 \mathrm{~nm}$ para todas as soluções analisadas.

Os comprimentos de onda utilizados para o monitoramento de emissão foram de $452 \mathrm{~nm}$ para PPIX e $480 \mathrm{~nm}$ para ZnPC. Como resposta do sistema laser computadorizado, obtêm-se um gráfico de decaimento experimental, ou seja, a variação da densidade óptica em função do tempo, bem como a curva que simula o decaimento observado. 


\subsubsection{Determinação do rendimento quântico de produção de oxigênio singlete} $\left(\Phi_{\Delta}\right)$

Neste estudo, utilizou-se o método direto para determinar-se o tempo de vida $\left(\tau_{\Delta}\right)$ e o rendimento quântico de produção do oxigênio singlete $\left(\Phi_{\Delta}\right)$ gerados pelo fotossensibilizador PPIX em meio homogêneo e ZnPC em meio lipossomal. Os valores de $\Phi_{\Delta}$ foram obtidos relativamente ao feoforbide-a em etanol $\left(\Phi_{\Delta}=0,59\right)$.

Os experimentos foram realizados em uma fonte de excitação utilizando o terceiro harmônico (355 nm) de um laser pulsado de Nd-YAG do Continuum, modelo Surelite 1-10. As soluções analisadas foram preparadas em seus respectivos meios de estudo, assegurando que no comprimento de onda de 355 nm a absorbância fosse da ordem de 0,3. As soluções foram acondicionadas em cubetas de fluorescência adaptadas para deaeração da amostra. Todas as soluções analisadas foram saturadas com $\mathrm{O}_{2}$ durante 30 minutos antes da análise. Como resposta do sistema laser computadorizado, obteve-se um gráfico da variação de intensidade de fosforescência em $1270 \mathrm{~nm}$ em função do tempo, bem como a curva com ajuste exponencial que melhor simulava o decaimento observado.

Nos estudos para determinação de produção de oxigênio singlete para os dois corantes estudados foi utilizado o composto feoforbide-a que apresenta um alto valor de rendimento quântico de oxigênio singlete $\left(\Phi_{\Delta}=0,59\right)$. Os tempos de vida de oxigênio singlete foram determinados através da transferência de energia entre o estado excitado triplete do fotossenssibilizador e o oxigênio molecular presente no meio.

A intensidade máxima de fosforescência no tempo 0 foi determinada pela regressão exponencial e os tempos de vida de oxigênio singlete foram determinados pelo tratamento do ajuste da curva. 


\subsection{Constituição, descrição e montagem do fotopolimerizador de resina odontológica e caracterização espectral da luz emitida}

O fotopolimerizador de resina odontológica (Figura 7), utilizado neste trabalho como fonte de luz fotossensibilizante, possui uma lâmpada halógena (Figura 7A) emissora de uma luz que, ao passar por um filtro (Figura 7B) acoplado ao suporte (C2), se condensa a uma banda mais estreita de luz, de comprimento de onda de 400 a $500 \mathrm{~nm}$ (filtro original do equipamento) ou 600 a $700 \mathrm{~nm}$ (filtro adaptado) a qual é conduzida através de uma ponteira (Figura 7D).

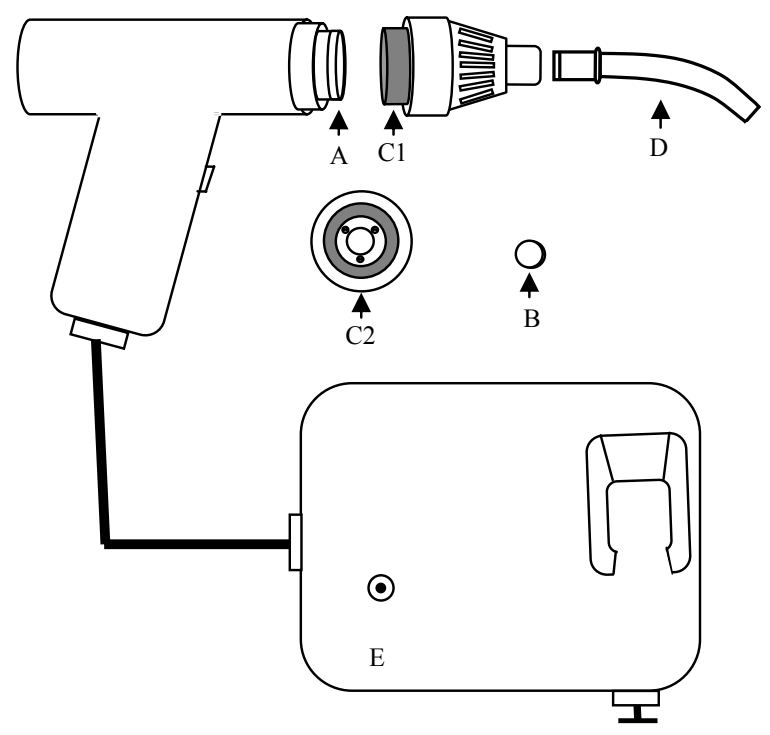

Figura 7: Fotopolimerizador de resina odontológica conforme descrito no Depósito de Patente $\mathrm{n}^{\circ}$ : PI 0404223-9 (PAULINO et al., 2004b): Fotopolimerizador manual de resina odontológica com ponteira autoclavável (D), vista lateral do suporte filtro luz (C1), vista frontal do suporte filtro de luz (C2), compartimento lâmpada halógena $(A)$, filtro de luz $(B)$ e setup de alimentação (E).

Ambas as faixas de transmitância foram determinadas através de um espectro de varredura dos filtros a qual foi realizada em um espectrofotômetro (Spectronic, Genesys 2) utilizando-se uma faixa de varredura de 300 a $800 \mathrm{~nm}$ com 2 nm de intervalo de leitura.

A potência da luz emitida pelo equipamento foi previamente estabelecida em um comprimento de onda respectivo ao espectro máximo de absorção de cada corante. Desta forma, a irradiação foi realizada num sistema (Power Meter - Field Master, Coherent, com uma cabeça de detecção LM-30V) onde, para o uso do equipamento, a ponteira do fotopolimerizador foi acoplada a um tubo de ensaio (120 x $12 \mathrm{~mm}$ ) adaptado uma distância de $11 \mathrm{~cm}$ do sistema de detecção de luz. Este tubo, quando utilizado para os experimentos de TFD, foi revestido com papel 
alumínio e posicionado de forma que a suspensão celular ficasse também a $11 \mathrm{~cm}$ da ponteira do fotopolimerizador na sua extremidade inferior, assim como posicionado para os sistemas de detecção de luz.

\subsection{Aplicação da Terapia fotodinâmica (TFD)}

\subsubsection{Avaliação dos efeitos citotóxicos da TFD aplicada ao $S$. mutans na presença ou ausência de diferentes agentes fotossensíveis}

Antes da incubação com diferentes concentrações de Rose Bengal (0 a 50 $\mu \mathrm{mol} / \mathrm{L})$, Protoporfirina IX (0 a $50 \mu \mathrm{mol} / \mathrm{L}$ ) e ZnPc (0 a $8,14 \mu \mathrm{mol} / \mathrm{L}$ ), a suspensão bacteriana $\left(10^{9} \mathrm{UFC} / \mathrm{mL}\right)$ foi serialmente diluída em PBS para a obtenção de $10^{3}$ UFC/mL. Após este procedimento, parte da preparação foi submetida ao controle de toxicidade no escuro e também pela fonte de luz. A outra parte da suspensão foi submetida ao experimento de morte celular com a adição de diferentes concentrações dos corantes em diferentes tubos de ensaio protegidos da luz ambiente. Assim, sob uma agitação branda, durante 10 minutos, as bactérias foram pré-incubadas e posteriormente irradiadas (30 segundos).

Após este tempo de irradiação, $50 \mu \mathrm{L}$ da suspensão celular (com ou sem células tratadas com os corantes) de todas as amostras (inclusive o controle) foram espalhados diretamente em placas de Petri contendo meio TSA; as placas foram protegidas da luz, colocadas em uma jarra de anaerobiose e incubadas a $37^{\circ} \mathrm{C}$ por 36 horas (Figura 8). Em seguida foi avaliado o número de UFC/mL. 


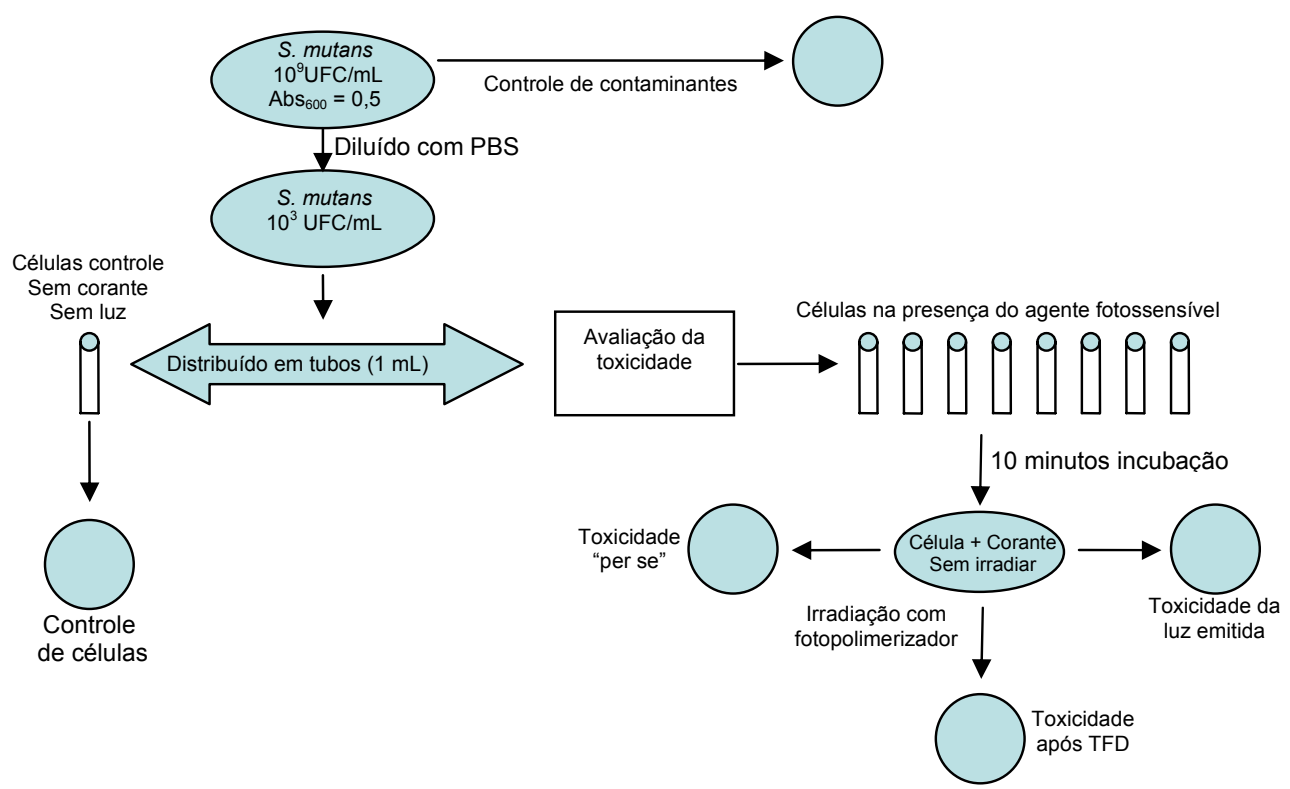

Figura 8: Fluxograma de eventos da metodologia aplicada para o emprego da TFD em $S$. mutans.

\subsubsection{Avaliação da formação de biofilme após TFD}

A capacidade de formação do biofilme foi avaliada após a exposição das células (constituintes de um biofilme) à TFD, em sua fase inicial de crescimento (2 horas). Assim, para a realização dos experimentos, a bactéria estoque foi submetida a três repiques sucessivos, e inoculada em meio completo (conforme descrito no item 3.3.5.1) enriquecido com sacarose $1 \%(\mathrm{p} / \mathrm{v})$. Para o crescimento do biofilme, a placa contendo o inóculo (Corning Costar) foi levada à estufa $\left(37^{\circ} \mathrm{C}\right.$, microaerofilia) durante 2 horas. Em seguida a placa foi retirada da estufa para a realização da troca do meio de cultivo (onde havia crescido o biofilme inicial) por uma solução salina (PBS) contendo separadamene Rose bengal, Protoporfirina IX ou Zinco Ftalocianina com 0,5; 0,2 e 3,72 $\mu \mathrm{mol} / \mathrm{L}$, respectivamente.

Imediatamente após a adição dos corantes, foi realizada a irradiação do biofilme (30 segundos) com o auxílio do fotopolimerizador de resina odontológica. Após a irradiação, a solução com os corantes foi retirada e novamente substituída por um novo meio de cultivo completo suplementado com $1 \%(p / v)$ de sacarose. Assim, por mais 2 horas, o biofilme foi mantido sob crescimento. Após este período, o meio de crescimento foi removido e cada "poço" foi lavado com PBS, seco a temperatura ambiente $\mathrm{e}$ as imagens foram capturadas através de um estereomicroscópio.

\subsubsection{Avaliação dos efeitos citotóxicos da TFD aplicada nos fibroblastos na presença ou ausência de diferentes agentes fotossensíveis}


Para a realização deste experimento, $1,0 \times 10^{6}$ células foram crescidas em meio DMEM-F12 como descrito por Paulino e colaboradores (PAULINO et al., 2005). As células foram isoladas por centrifugação e lavadas duas vezes com HBSS. A concentração inicial de células usadas em todos os experimentos foi de $0,7 \times 10^{6}$ células $/ \mathrm{mL}$ em HBSS. $1 \mathrm{~mL}$ desta suspensão de foi distribuída em tubos de ensaio $(120 \times 12 \mathrm{~mm})$. Após isto, parte foi separadamente submetida ao controle de toxicidade do corante e da luz per se. Uma outra parte da suspensão celular foi submetida ao experimento de irradiação com adição de diferentes concentrações de Rose Bengal (0 a $50 \mu \mathrm{mol} / \mathrm{L})$, Protoporfirina IX (0 a $20 \mu \mathrm{mol} / \mathrm{L})$ e Zinco ftalocianina (meio lipossomal com 0 a 8,14 $\mu \mathrm{mol} / \mathrm{L}$ ) em diferentes tubos (120 x $12 \mathrm{~mm}$ ). Sob suave agitação as células foram incubadas por 10 minutos, assim como feito para o S. mutans, com subseqüente irradiação com o fotopolimerizador durante 30 segundos. Após estes procedimentos, as células foram centrifugadas e ressuspensas em meio de cultivo DMEM/F-12.

Em seguida a cultura ressuspensa foi levada a uma incubadora de $\mathrm{CO}_{2}$ e a viabilidade celular foi avaliada a partir da técnica do MTT ou Azul Tripan, conforme descrito a seguir.

\subsubsection{Determinação da viabilidade celular}

\subsubsection{Ensaios com Azul Tripan}

A solução azul tripan na concentração de $0,1 \%(p / v)$ foi preparada $e$ posteriormente filtrada em um filtro $0,22 \mu \mathrm{m}$. A suspensão celular foi diluída na proporção 1:1 (v/v) com o corante. Após 10 minutos de incubação esta suspensão foi diluída apropriadamente em solução salina (PBS) para permitir uma fácil contagem de células em cada campo de uma câmara de Neubauer, possibilitandose assim estimar a relação que há entre as células viáveis e as células lisadas.

\subsubsection{Ensaios com MTT}

A viabilidade celular foi determinada utilizando-se ensaio com 3-(4,5-dimetil tiazol-2-il)-2,5-difenil brometo de tetrazolina (MTT), (KAWADA et al., 2002). O teste é baseado na capacidade de células viáveis a reduzirem a base de tetrazolina a um produto azul, denominado formazam (MOSMMAN, 1983). 
As células, após o crescimento em estufa, foram homogeneizadas no próprio meio de cultivo (1,0 mL). Em seguida, $1,0 \mathrm{~mL}$ da solução de MTT $(0,5 \mathrm{mg} / \mathrm{mL})$ foi adicionado a cada poço e incubados a $37^{\circ} \mathrm{C}$ durante 4 horas.

Ao final do período de incubação, o meio pode ser removido e o corante formado no fundo do poço (formazam) foi dissolvido com $300 \mu \mathrm{L}$ de isopropanol (0,04 $\mathrm{mol} / \mathrm{L} \mathrm{HCl}$ em isopropanol absoluto). A solução foi repipetada pelo menos 3 vezes para garantir uma completa dissolução do corante em isopropanol. A absorção (em $570 \mathrm{~nm}$ ) da solução resultante foi medida com uma subtração de um branco $(650 \mathrm{~nm})$. Para estas leituras foi utilizado um leitor de ELISA da Labsystem.

\subsubsection{Pulso de carboidratos para avaliação da capacidade acidogênica de $S$. mutans}

Foi avaliada a capacidade de bactérias em meio planctônico de acidificar o meio após a adição de uma fonte de carbono. As células foram crescidas em microaerofilia no meio completo, acrescido de glicose $(50 \mathrm{mmol} / \mathrm{L})$ até que a densidade óptica alcançasse um valor aproximado de 1. Este meio de cultivo contendo as células foi então centrifugado (3.000 xg, 20 minutos) e lavado duas vezes em tampão salino ( $\mathrm{NaCl} \mathrm{0,9 \% ).} \mathrm{Finalmente,} \mathrm{ao} \mathrm{final} \mathrm{das} \mathrm{duas} \mathrm{lavagens,} \mathrm{as}$ células foram novamente centrifugadas e o pellet foi ressuspenso no mesmo tampão, sua densidade óptica corrigida para 1,0 (Abs 600 final $=1,0)$ e o pH estabilizado em aproximadamente $6-7$ com uma solução de hidróxido de potássio 0,1 mol/L. Em seguida estas células foram submetidas a diferentes condições experimentais:

- avaliação da variação do pH sem adição de nenhuma fonte de carbono;

- avaliação da variação do pH sem suplementação com fonte de carbono e suplementado com fluoreto de sódio (1 mmol/L);

- avaliação da variação do pH de suspensão suplementada separadamente com glicose, frutose, sacarose, maltose e xilose (50 mmol/L),

- avaliação da variação do pH de uma suspensão suplementada separadamente com glicose, frutose, sacarose, maltose e xilose $(50 \mathrm{mmol} / \mathrm{L})$ e acrescido de fluoreto de sódio ( $1 \mathrm{mmol} / \mathrm{L})$

Assim, após a prévia incubação, o pH destas suspensões celulares foi avaliado, sob agitação constante, durante 600 segundos e, com os dados coletados 
foi construído um gráfico onde são representadas as variações de $\mathrm{pH}$ durante o tempo em relação ao $\mathrm{pH}$ inicial usando a seguinte fórmula:

$$
\Delta \mathrm{pH}=\mathrm{pH}(\text { tempo } \mathrm{zero})-\mathrm{pH}\left(\text { Tempo }_{600}-\mathrm{x}\right) ; \text { para } \mathrm{X} \leq 600 \text { segundos. }
$$

\subsubsection{Pulso de glicose para avaliação da capacidade acidogênica de $S$. mutans após TFD}

Conforme metodologia descrita, uma nova suspensão celular foi produzida para avaliar a capacidade acidogênica do S. mutans após a TFD.

Em seguida estas células foram submetidas a diferentes condições experimentais:

- avaliação da variação do pH sem adição de glicose, grupo controle sem glicose;

- avaliação da variação do pH após suplementação da suspensão celular com glicose (50 mmol/L final), grupo controle com glicose;

- avaliação da variação do pH após prévia incubação com Rose bengal (0,5 $\mu \mathrm{mol} / \mathrm{L})$ ou Protoporfirina IX (0,2 $\mu \mathrm{mol} / \mathrm{L})$ ou ZnPc-lipossomo (3,78 $\mu \mathrm{mol} / \mathrm{L})$, irradiados com luz proveniente do fotopolimerizador de resina odontológica (filtro de 400 - 500nm para o Rose Bengal e Protoporfirina IX; filtro de 600700 nm para a ZnPc-lipossomo) e acrescidos com $50 \mathrm{mmol} / \mathrm{L}$ final de glicose, para avaliação da TFD sobre a capacidade acidogênica;

- avaliação da variação do pH sem glicose e com uma irradiadiação de 30 segundos com luz proveniente do fotopolimerizador de resina odontológica, (filtro de 400-500 nm ou 600-700 nm), para avaliação do efeito da luz;

- incubado com Rose bengal $(0,5 \mu \mathrm{mol} / \mathrm{L})$ ou Protoporfirina IX $(0,2 \mu \mathrm{mol} / \mathrm{L})$ ou Zinco ftalocianina $(3,78 \mu \mathrm{mol} / \mathrm{L})$, incubados previamente por 10 minutos sem uma posterior adição de carboidrato, para avaliação do efeito per se dos agentes fotessensíveis.

Assim, cada grupo, após a prévia incubação,foi submetido a uma irradiação (30 segundos) com luz proveniente do fotopolimerizador (exceto controles sem luz), e acrescido de glicose (50 mmol/L final). Imediatamente, sob agitação constante, os grupos foram monitorados quanto a sua capacidade acidogênica durante 600 segundos (avaliação da variação do pH). 
Desta forma foi construído um gráfico onde são representadas as variações de pHdurante o tempo em relação ao pH inicial conforme descrito no item anterior.

\subsection{Obtenção das frações microssomais de membrana de Streptococcus mutans}

As frações de membrana rica em $\mathrm{H}^{+}$-ATPase foram obtidas de acordo com a metodologia descrita por Bender e colaboradores (BENDER et al., 1986) com algumas modificações detalhadas a seguir.

Para a preparação das células, um inóculo de $4 \mathrm{~mL}$ de uma cultura de 12 horas de $S$. mutans (meio completo suplementado com $50 \mathrm{mmol} / \mathrm{L}$ glicose) foi realizado em 1,0 litro deste mesmo meio de cultivo estéril. $O$ crescimento bacteriano foi monitorado até que $\mathrm{o} \mathrm{pH}$ do meio de cultivo alcançasse um valor de aproximadamente 4 (equivalente a fase estacionária de crescimento deste microrganismo).

Ao final do crescimento, as células foram retiradas do meio por centrifugação $\left(9.000 \mathrm{xg}, 10\right.$ minutos, $\left.20^{\circ} \mathrm{C}\right)$ em centrífuga sorval e o pellet obtido foi pesado. Cerca de $1,0 \mathrm{~g}$ (peso úmido) de células de Streptococcus mutans foram lavadas duas vezes com $15 \mathrm{~mL}$ de PBS e seguido por uma nova centrifugação (9.000 xg, 10 minutos, $20^{\circ} \mathrm{C}$ ). O pellet obtido foi ressuspenso em tampão MES $25 \mathrm{mmol} / \mathrm{L}$, pH 6,2 contendo $97 \mathrm{~mol} / \mathrm{L}$ de NaSCN (Tampão de Preparação) até absorbância de 0,4 em $700 \mathrm{~nm}$, homogeneizado em potter e em seguida foi adicionado $0,4 \mathrm{mg} / \mathrm{mL}$ de lisozima. A mistura foi deixada por 3 horas a $25^{\circ} \mathrm{C}$ com suave agitação e em seguida centrifugada a $9.000 \mathrm{xg}$ por 20 minutos a $4^{\circ} \mathrm{C}$. O pellet obtido foi ressuspenso em 50 $\mathrm{mL}$ de Tampão MES $50 \mathrm{mmol} / \mathrm{L}$, pH 6,2 contendo $10 \mathrm{mmol} / \mathrm{L}$ de $\mathrm{MgSO}_{4}$ e 0,8 mol/L de $\mathrm{NaCl}$ (Tampão de Choque Osmótico).

Esta solução foi sonicada por 20 minutos, com intervalos de 5 em 5 minutos para manter a temperatura por volta de $4^{\circ} \mathrm{C}$, utilizando-se um sonicador de ponta Vibracell 600V, a $50 \%$ de amplitude. Em seguida foram adicionados $175 \mathrm{U} / \mathrm{mL}$ de DNAase e $250 \mu \mathrm{L} / \mathrm{g}$ de célula de coquetel de inibidor de proteases e deixado por 45 minutos à temperatura ambiente com agitação suave. $O$ material assim obtido foi ultracentrifugado a $100.000 x g$ por 1 hora a $4^{\circ} \mathrm{C}$. O pellet que corresponde a fração de membrana rica em $\mathrm{H}^{+}$-ATPase foi ressuspenso em tampão MES $25 \mathrm{mmol} / \mathrm{L} \mathrm{pH}$ 6,2, a concentração de proteína foi estimada (HARTREE, 1972) e em seguida as 
membranas foram novamente tratadas com lisozima em uma proporção de 1:1 (p/p) por 2 horas à temperatura ambiente com agitação suave. Essa solução foi novamente ultracentrifugada a $100.000 x g$ por 1 hora a $4^{\circ} \mathrm{C}$ e ressuspensa em $30 \mathrm{~mL}$ de Tampão de Choque Osmótico e mantida em geladeira durante 12 horas .

Em seguida a mistura foi retirada da geladeira e colocada em banho de ultrassom por 1 hora. Essa mistura foi então centrifugada (9.000 xg, 10 minutos, $4^{\circ} \mathrm{C}$ ) e o sobrenadante obtido fopi recolhido e ultracentrifugado (100.000xg por 1 hora a $4^{\circ} \mathrm{C}$ ). $\mathrm{O}$ pellet obtido foi ressuspenso em $15 \mathrm{~mL}$ de tampão Tris. $\mathrm{HCl} 50$ $\mathrm{mmol} / \mathrm{L}$, pH 7,5 contendo $10 \mathrm{mmol} / \mathrm{L}$ de $\mathrm{MgSO}_{4}$ (Tampão de Estoque). As frações de membrana foram imediatamente aliquotadas para serem utilizadas ou congeladas em nitrogênio líquido para serem armazenadas $\mathrm{a}-20^{\circ} \mathrm{C}$.

\subsection{Quantificação da proteína}

A concentração de proteína foi estimada de acordo com o método de Hartree (HARTREE, 1972) na presença de SDS $2 \%(p / v)$ utilizando-se albumina bovina (BSA) como padrão.

\subsection{Influência da TFD sobre a atividade ATPase total de fração microssomal de membrana de $S$. mutans}

A atividade ATPase total da membrana de S. mutans ou a atividade ATPase da membrana após tratamento com TFD com os diferentes corantes foi determinada descontinuamente, a $37^{\circ} \mathrm{C}$, em um espectrofotômetro, através da dosagem do fosfato inorgânico liberado em meio reacional Bis. Tris 50 mmol/L, pH 6,5 (atividade ATPase total), contendo ATP $5 \mathrm{mmol} / \mathrm{L}$, e $\mathrm{MgCl}_{2} 10 \mathrm{mmol} / \mathrm{L}$ em volume final de 1,0 $\mathrm{mL}$.

Para a realização da TFD, a fração microssomal de membrana foi previamente tratada com Rose Bengal, Protoporfirina ou Zinco ftalocianina $(0,05 ; 0,02$ e 0,37 $\mu \mathrm{mol} / L$, respectivamente) separadamente e imediatamente irradiada (90 segundos) pela luz emitida pelo fotopolimerizador de resina odontológica.

A reação foi sempre iniciada pela adição de ATP ao meio reacional e interrompida pela adição de solução gelada de TCA $30 \%(p / v)$, em tempos reacionais preestabelecidos (MAGALHÃES et al., 2005). 
Durante a irradiação e após o término da reação, os tubos foram mantidos em banho de gelo, diminuindo a hidrólise do ATP. Ao término da reação, os tubos foram imediatamente centrifugados por 10 minutos e, em seguida, efetuada a dosagem de fosfato, seguindo o método descrito por Heinonen e Lahti (HEINONEM \& LATHI, 1981). Em cada experimento foram incluídos controles sem a enzima, para se estimar a hidrólise não enzimática do substrato e das amostras contendo somente corantes, estimando-se assim a absorção de luz por estas espécies. Tubos com enzima, sem corante e com luz e com corante e sem luz foram avaliados também para determinação do efeito per se da luz e da droga sozinhos. As determinações foram sempre feitas em duplicatas e tomando-se o cuidado de não hidrolisar mais que $5 \%$ de substrato. Uma unidade de enzima foi definida arbitrariamente como sendo $1 \mathrm{nmol}$ de fosfato liberado por minuto, nas condições padrões do teste.

\subsection{Expressão e análise de proteínas de estresse (Heat Shock Protein - HSP) em S. mutans após TFD}

\subsubsection{Cultivo e tratamento das células}

Para o crescimento das bactérias, um inóculo $(3,75 \mu \mathrm{L} / \mathrm{mL})$ foi realizado em 1,0 litro de meio completo estéril, suplementado com $50 \mathrm{mmol} / \mathrm{L}$ de glicose e tamponado com $50 \mathrm{mmol} / \mathrm{L}$ de MOPS. Este meio de cultivo foi então mantido em estufa microbiológica $\left(37^{\circ} \mathrm{C}\right)$, sob agitação suave, durante 8 horas, até que $\circ \mathrm{pH}$ do meio de cultivo alcançasse um valor aproximado de 6,7 com uma densidade ótica de \pm 1 .

Após o crescimento, o meio de cultivo foi fracionado em 3 frascos $(200 \mathrm{~mL}$ cada) para avaliação da:

- capacidade de indução ao estresse per se do corante Rose bengal $(0,1$ $\mu \mathrm{mol} / \mathrm{L}$ ) sem a irradiação com luz;

- capacidade de indução ao estresse per se da luz (120 segundos) sem a adição de um agente fotossensível.

- capacidade de indução ao estresse após emprego da TFD com Rose bengal $(0,1 \mu \mathrm{mol} / \mathrm{L})$ e com 120 segundos de irradiação com a luz.

Além disso, outros 2 frascos contendo $200 \mathrm{~mL}$ de meio de cultivo foram utilizados como controle negativo para cepa não irradiada e sem o corante (controle 
de estresse negativo) e como controle positivo para uma cepa estimulada a produzir HSP após a adição de $1 \mathrm{~mol} / \mathrm{L}$ de cloreto de sódio (estresse osmótico).

Após os respectivos tratamentos citados, as células foram novamente levadas à estufa microbiológica $\left(37^{\circ} \mathrm{C}\right.$, microaerofilia) por 5 minutos e posteriormente foi adicionado cloranfenicol (1 $\mathrm{mmol} / \mathrm{L})$ afim de interromper a síntese protéica das células tratadas.

Estas amostras foram mantidas a $4^{\circ} \mathrm{C}$ e centrifugadas $(9.000 \mathrm{xg})$ durante 30 minutos, o pellet foi ressuspenso em PBS (suplementado com $1 \mathrm{mmol} / \mathrm{L}$ de cloranfenicol) duas vezes para lavagem.

\subsubsection{Lise bacteriana para obtenção de proteínas de estresse (Heat Shock Protein - HSP) de S. mutans}

Os pellets obtidos foram pesados e ressuspensos em tampão de lise bacteriana (Uréia $8 \mathrm{~mol} / \mathrm{L}$, DTT $62 \mathrm{mmol} / \mathrm{L}$ e Igepal 2\% (v/v)) numa proporção de 5 $\mathrm{mL}$ de tampão de lise para cada 1 grama de célula na presença de pérolas de vidro $(\mathrm{p} / \mathrm{p})$ (Glass Beads).

Em seguida, as células foram sonicadas (5 minutos) com sonicador de ponta (220 Watts) em banho de gelo. Ao final do procedimento as células foram vortexadas vigorosamente durante 10 minutos. Os tubos contendo o material lisado foram centrifugados (20 minutos, 3.000xg) para separar células não lisadas e as pérolas de vidro do sobrenadante. O sobrenadante foi coletado e a concentração de proteína foi estimada conforme descrito no Item 3.11.

\subsection{Análise por SDS-PAGE e "Western Blotting"}

A determinação do peso molecular das proteínas foi obtida por SDS-PAGE como descrito por LAEMMLI (1970). Resumidamente, 5\% de poliacrilamida foi usada para o gel de empacotamento e $7,5 \%$ para o gel de corrida. O gel foi corado pela

prata para visualização do perfil protéico. "Western Blotting" foi realizado por transferência das bandas protéicas para uma membrana de nitrocelulose ( 2 horas, 300-400 mA). A membrana foi tratada com solução bloqueadora (PBS, contendo 5\% $(\mathrm{p} / \mathrm{v})$ de leite em pó desnatado e 0,05\% (v/v) Tween 20) por $1 \mathrm{~h}$ e sondada com anticorpo Anti-GroEL (1:1000) em solução bloqueadora por 2 horas a $4^{\circ} \mathrm{C}$. A 
membrana de nitrocelulose foi lavada com PBS-tween $20 \quad(0,05 \%)$ durante 30 minutos em constante agitação e posteriormente incubada com anticorpo de cabra anti-IgG (GAR) conjugado a peroxidase (diluição 1:1000) por 1,5 h. Novamente a membrana de nitrocelulose foi lavada com PBS-tween $20(0,05 \%$ p/v) por 30 minutos em constante agitação, revelada (DAB e peróxido hidrogênio $30 \%(v / v)$ ) e bloqueada com água destilada. Em seguida a imagem foi capturada e digitalizadas em Scanner.

\subsection{Estudos de peroxidação lipídica em S. mutans: ação sobre a fração de membrana e em bactérias em meio planctônico}

\subsubsection{Fração de membrana}

As frações de membrana obtidas (Item 3.10) foram submetidas a um prévio tratamento com a TFD. Assim, $100 \mu \mathrm{L}$ da fração obtida foi tratada com os agentes fotossensíveis Rose bengal, Protoporfirina IX e ZnPc-lipossomo nas concentrações finais de 0,$5 ; 0,2$ e $3,78 \mu \mathrm{mol} / \mathrm{L}$, respectivamente. Em seguida, as amostras foram irradiadas (30 segundos) e a atividade enzimática foi avaliada conforme descrito no item 3.12.

Os grupos foram preparados conforme descrito abaixo:

- Grupo experimental: suspensão celular tratada com os agentes fotossensíveis, seguidos pela irradiação de luz.

- Grupo controle positivo: fração de membrana foi tratada com peróxido de hidrogênio $(0,5 \mathrm{mmol} / \mathrm{L})$ e Sulfato de ferro II $(1 \mathrm{mmol} / \mathrm{L})$, produzindo peróxidos reativos (reação de Fenton, Equação 3.4)

$$
\mathrm{Fe}^{2+}+\mathrm{H}_{2} \mathrm{O}_{2} \Leftrightarrow \mathrm{Fe}^{3+}+\mathrm{OH}^{-}+\mathrm{HO}
$$

- Amostra branco: fração de membrana não tratada com TFD ou peróxidos (via reação de Fenton).

Ao final do tratamento (Fenton ou TFD), adicionou-se $50 \mu \mathrm{L}$ de uma solução de ácido fosfórico $7 \%(\mathrm{v} / \mathrm{v}$ ) e $100 \mu \mathrm{L}$ de uma solução de ácido Tiobarbitúrico $1 \%$ (em $\mathrm{NaOH} 50 \mathrm{mmol} / \mathrm{L}$ ), homogenizou-se em seguida deixando durante 10 minutos. Em seguida a solução foi aquecida ( $95^{\circ} \mathrm{C}$ durante 15 minutos). Após esfriar, os valores de absorbância foram coletados em $532 \mathrm{~nm}$. 


\subsubsection{Bactérias em meio planctônico}

Células íntegras de S. mutans, cultivadas por 12 horas em meio de cultivo líquido (TSB) foram centrifugadas a $3.000 \times$ para a obtenção de um pellet bacteriano que foi posteriormente lavado em solução PBS (2 lavagens) para novamente ser centrifugado.

O pellet obtido foi ressuspenso em um tampão PBS até concentração de 0,5 $\left(\right.$ Abs $\left._{600 n m}\right)$. Estas suspensão celular foi então tratada com os agentes fotossensíveis Rose bengal, Protoporfirina IX e ZnPz-lipossomo com as concentrações finais de 0,5; 0,2 e 3,78 $\mu \mathrm{mol} / \mathrm{L}$, respectivamente.

Posteriormente, estas células foram irradiadas com a luz proveniente do fotopolimerizador de resina odontológica, com os filtros de luz respectivos aos corantes empregados, durante 30 segundos.

Os grupos foram preparados conforme descrito abaixo:

- Grupo experimental: suspensão celular tratada com o agente fotosenssível, seguido pela irradiação de luz.

- Grupo controle positivo: suspensão celular, tratada com peróxido de hidrogênio $(0,5 \mathrm{mmol} / \mathrm{L})$ e Sulfato de ferro II $(1 \mathrm{mmol} / \mathrm{L})$, produzindo peróxidos reativos (reação de Fenton)

- Amostra branco: suspensão celular, não tratada com TFD ou peróxidos (via reação de Fenton).

Ao final do tratamento (Fenton ou TFD), adicionou-se $50 \mu \mathrm{L}$ de uma solução de ácido fosfórico $7 \%(\mathrm{v} / \mathrm{v})$ e $100 \mu \mathrm{L}$ de uma solução de ácido Tiobarbitúrico 1,0 \% $(\mathrm{p} / \mathrm{v})$ preparada em $\mathrm{NaOH} 50 \mathrm{mmol} / \mathrm{L}$, homogenizou-se para em a solução foi mantida em repouso durante 10 minutos. Em seguida, a solução foi aquecida $\left(95^{\circ} \mathrm{C}\right.$ durante 15 minutos). Após esfriar, os valores de absorbância foram avaliados em $532 \mathrm{~nm}$.

\subsection{Efeito da terapia fotodinâmica sobre o DNA de S. mutans}

\subsubsection{Emprego da TFD sobre as células}

Uma suspensão celular (Abs $600 \mathrm{~nm}=0,5$ ) em PBS foi tratada com os agentes fotosensíveis Rose bengal, Protoporfirina IX e ZnPc-lipossomo nas respectivas concentrações de 0,$5 ; 0,2$ e $3,78 \mu \mathrm{mol} / \mathrm{L}$. Posteriormente foram irradiadas (30 
segundos) com a luz proveniente do fotopolimerizador de resina odontológica (utilizando-se para isso os filtros de luz correspondentes aos agentes fotossensíveis).

Em seguida estas células foram centrifugadas $(3.000 \mathrm{xg})$ e o pellet foi submetido à extração do DNA genômico.

\subsubsection{Extração de DNA genômico bacteriano}

O DNA genômico das amostras foi extraído pelo método descrito por Pitcher (PITCHER, 1989). O crescido bacteriano foi incubado a $37^{\circ} \mathrm{C}$ por 30 minutos em uma solução contendo solução tamponante TE (10 mmol/L Tris, $1 \mathrm{mmol} / \mathrm{L}$ EDTA) pH 8,0 , contendo sacarose a $25 \%(\mathrm{p} / \mathrm{v})$ e lisozima $50 \mathrm{mg} / \mathrm{mL}$. Após incubação a $37^{\circ} \mathrm{C}$ foram adicionados ao tubo $500 \mu \mathrm{L}$ de tampão GES $(5 \mathrm{~mol} / \mathrm{L}$ de tiocianato de guanidina, 0,1 mol/L de EDTA e 0,5 \% (p/v) de sarcosil-solução a 30\% (p/v) de sarcosinato lauril sódio, promovendo-se então a lise bacteriana.

Ao lisado bacteriano, foram adicionados $250 \mu \mathrm{L}$ de acetato de amônio 7,5 $\mathrm{mol} / \mathrm{L}$, misturados e incubados por 10 minutos no gelo. A seguir, foram adicionados ao tubo $500 \mu \mathrm{L}$ de clorofórmio/2-pentanol (1:1, v/v), o mesmo foi agitado vigorosamente por 10 minutos e depois centrifugado por 10 minutos a $10.000 x g$.

O sobrenadante $(700 \mu \mathrm{L})$ foi transferido para um novo tubo, ao qual foram adicionados $875 \mu \mathrm{L}$ de etanol absoluto armazenado a $-20^{\circ} \mathrm{C}$ e o tubo foi mantido a $20^{\circ} \mathrm{C}$ por $18-24 \mathrm{~h}$.

Após esta incubação, o tubo foi centrifugado por 3 minutos a $10.000 \times \mathrm{xg}$, o sobrenadante foi desprezado e foram adicionados $100 \mu \mathrm{L}$ de acetato de amônio letanol $(1: 1, v / v)$, seguido de uma nova centrifugação nas mesmas condições da anterior. Desprezado o sobrenadante, o DNA contido no tubo foi precipitado com etanol absoluto armazenado a $-20^{\circ} \mathrm{C}$ e o tubo foi novamente centrifugado. Por último, o sobrenadante foi desprezado e o tubo contendo o DNA deixado aberto em câmara de fluxo laminar para secagem. Posteriormente, o DNA foi ressuspenso em $100 \mu \mathrm{L}$ de solução tamponante TE $(10 \mathrm{mmol} / \mathrm{L}$ Tris, $1 \mathrm{~mol} / \mathrm{L}$ EDTA $) \mathrm{pH} \mathrm{8,0} \mathrm{e}$ incubado $18-24 \mathrm{~h}$ a $4^{\circ} \mathrm{C}$.

A quantificação do DNA para posterior aplicação no gel foi realizada no "GeneQuant pro RNA/DNA calculator" (Amersham Pharmacia Biotech) de acordo com os seguintes parâmetros: concentração de DNA $(\mu \mathrm{g} / \mathrm{mL})$, absorbância em 230nm, 260nm (quantificação de DNA e RNA, respectivamente), 280nm (quantificação de proteínas). As amostras foram aplicadas em gel de agarose (1\%, $\mathrm{p} / \mathrm{v}$ ) e reveladas na presença de brometo de etídio.

\subsection{Microscopia Eletrônica de Transmissão do S. mutans}


Uma cultura celular, fase estacionária (12 horas de crescimento) foi centrifugada (3.000xg, durante 15 minutos) e ressuspensa em tampão PBS para lavagem. Esta suspensão foi novamente centrifugada e o pellet, constituído por células livres de meio de cultivo, foi incubado com uma solução de glutaraldeído 3\% (v/v) por 1 hora. Esta suspensão foi trocada pelo mesmo volume de tampão Tris-HCl $5 \mathrm{mmol} / \mathrm{L}, \mathrm{pH} 7,5$. Em seguida, o material foi ressuspenso separadamente em uma solução de ósmio 1\% (p/v) preparada no mesmo tampão da incubação. Após 1 hora de repouso, o pellet foi lavado em tampão fosfato de sódio 0,1 mol/L, pH 7,3, centrifugado e desidratado com concentrações crescentes de acetona/água, variando de 30 a 95\% (v/v) com intervalos de 5 minutos para cada troca. A última desidratação foi realizada com acetona $100 \%$ durante 10 minutos, por 3 vezes. Finalmente o pellet foi infiltrado em resina de araldite a $37^{\circ} \mathrm{C}$ durante 48 horas e incluso em araldite pura durante 72 horas a $60^{\circ} \mathrm{C}$. Cortes de aproximadamente 0,5 $\mu \mathrm{m}$ foram realizados com o ultramicrótomo e contrastados em acetato de uranila $4 \%$ (p/v), $\mathrm{pH} 12$, por 10 minutos seguido de citrato de chumbo 0,3\% (p/v), $\mathrm{pH} 12$, durante mais 10 minutos. As imagens foram capturadas em um equipamento Philips, Modelo 208, localizado no Departamento de Morfologia da Faculdade de Medicina de Ribeirão Preto - USP.

\subsection{Descarte das células}

As células, bactérias, meios de cultivo e outros materiais contaminados ou não utilizados nos experimentos foram autoclavados a $121^{\circ} \mathrm{C}$ durante 20 minutos e posteriormente descartados. 


\section{RESULTADOS e DISCUSSÃO:}

\subsection{Otimização das condições de crescimento de S. mutans}

Streptococcus mutans é uma bactéria normalmente presente na microbiota bucal e sua relação com o surgimento da cárie dental é evidente. Esta relação é em parte devida à grande capacidade acidogênica deste organismo, principalmente devido à formação de ácidos orgânicos como o lático, acético e o propiônico (PAULINO et al., 2003).

A Figura 9A mostra uma curva de crescimento da bactéria $S$. mutans, sem fonte de carbono ou com glicose, com xilose ou glicose e xilose associados, suplementando o meio em condições microaerófilas. Nas primeiras 5 horas de crescimento (fase "lag") pode ser observado que a multiplicação celular, medida pela densidade óptica do meio em $600 \mathrm{~nm}$, é consideravelmente pequena. Nesta fase (também denominada preparatória) as células monitoram o meio de cultivo (analisando os possíveis nutrientes presentes) e sintetizam seu aparato enzimático para a próxima etapa do crescimento. No meio suplementado com glicose ou com a mistura (glicose e xilose), durante as 7 horas subseqüentes à fase "lag" a bactéria se reproduz em escala exponencial. Isto pode ser observado, pois a turbidez do meio aumenta rapidamente (fase "log"). Finalmente, após 12 horas de cultivo, surge uma fase onde não há um crescimento substancial (fase estacionária), devido à depleção de alguns nutrientes e/ou grandes quantidades de metabólitos tóxicos gerados como produtos finais do metabolismo. A mistura de xilose ao meio de cultivo não afeta a cinética de crescimento das células quando comparado ao meio de cultivo suplementado somente com glicose.

No meio ao qual apenas a xilose foi adicionado como fonte de carbono, é observado um pequeno aumento na turbidez durante 2 horas após a fase "log", sendo que posteriormente este se estabiliza e dá lugar a uma fase estacionária prematura (Figura 9A). Este fato sugere que $S$. mutans não metaboliza a xilose, pois um crescimento similar é obtido quando o cultivo é realizado em meio sem nenhuma fonte de carbono. O pequeno crescimento, nestas duas condições, mostra que a bactéria possui algumas reservas intracelulares de energia na forma de polissacarídeos, como já descrito na literatura (PAULINO et al., 2003). Estas reservas podem ser suficientes para iniciar o crescimento, mas insuficientes para 
mantê-lo, interrompendo-se assim a progressão da cultura.

$\mathrm{Na}$ Figura 9B pode ser observado que no meio de cultivo o decaimento mais significativo do $\mathrm{pH}$ ocorre durante a fase "Log" do crescimento para o meio suplementado com glicose ou com a mistura (glicose e xilose). Entretanto, no meio sem nenhuma fonte de carbono ou suplementado apenas com xilose, o decaimento é menos significativo. Em todas as situações, o decaimento do $\mathrm{pH}$ é devido principalmente à produção dos ácidos orgânicos, sendo sua produção devida ao metabolismo anaeróbico da glicose pelo S. mutans (PAULINO et al., 2003). Já para o meio de cultivo sem a adição de carboidrato ou suplementado apenas com xilose, a quantidade de açúcar fermentado é pequena (restrito apenas às reservas intracelulares), sendo a acidificação conseqüentemente menor.

A quantidade de glicose presente no meio de cultura foi monitorada durante 0 período de crescimento (Figura 10). Nesta figura é observado que ao decorrer o período entre a fase "Log" e estacionária $\left(5^{\mathrm{a}}-12^{\mathrm{a}}\right.$ hora), há um rápido decaimento da quantidade de açúcar que alcança um mínimo no início da fase estacionária, sendo um dos fatores que explicam a parada no crescimento durante esta fase. $O$ alto consumo de glicose durante a fase "Log" mostra claramente o intenso metabolismo da bactéria, visando manutenção da atividade celular e um aumento do número de células (Figura 9A), o que explica a grande produção de ácido (Figura 9B) durante esta fase de crescimento. Estas observações são confirmadas por uma análise de TLC do meio de cultivo durante diferentes fases do crescimento (Figura 11). Nesta Figura é observado que a glicose é gradualmente consumida, desaparecendo ao final da fase "Log" (Linhas 1-4), enquanto que a xilose é detectada durante todo o período estudado (Linha 5-8). Nas Linhas 9 - 11, pode- se observar que a mistura de glicose e xilose afeta a migração de ambos os carboidratos. Desta forma a progressiva atenuação das manchas (5-8) reflete o consumo de glicose, enquanto que a xilose permanece constante.

A não metabolização da xilose reflete um interessante aspecto, porque esta pentose pode ser usada através de uma via do metabolismo denominada via "das pentoses fosfato" cuja função principal é a produção de potencial redutor (NADPH) e a interconversão de açúcares com um número de carbonos entre três e sete (NELSON \& COX, 2000). Entretanto, S. mutans não possui enzimas oxidativas da via das pentoses fosfato e aparentemente usa a ribose para fornecer átomos de carbono para a biosíntese de aminoácido (ROLLA, 1989). 
Desta forma, nenhum crescimento significante é apresentado na presença de xilose (Figura 9A), isto sugere que a bactéria é incapaz de transportar este açúcar para dentro da célula e/ou convertê-lo em algum intermediário da via das pentoses fosfato (PAULINO et al., 2003).

Posteriormente, nossos estudos se dirigiram a uma análise da formação do biofilme de $S$. mutans na presença de diferentes tipos de fonte de carbono e/ou na presença de um clássico agente antibacteriano, o fluoreto de sódio.

Na Figura 12 é apresentada uma foto de uma placa de 24 poços após 12 horas de crescimento. O biofilme pode ser visualizado pela sua aparência opaca no fundo do poço. Sua intensidade varia em função da fonte de carbono e da concentração de flúor. Assim, na coluna 5 (crescimento na presença de sacarose) um biofilme mais intenso é observado, inclusive na presença de $5 \mathrm{mmol} / \mathrm{L}$ de flúor (coluna 5, linha D (D5), enquanto que, na coluna 3 (crescimento na presença de glicose) um biofilme menos intenso é formado. Além disso, este biofilme é progressivamente reduzido com o aumento da concentração de flúor (coluna 3, (B3), (C3) e (D3). A mesma observação é feita para o crescimento na presença de maltose (coluna 1) e frutose (coluna 4). Quando a xilose ou nenhuma fonte de carbono é adicionada ao meio de crescimento, nenhum biofilme pode ser observado a olho nú, (coluna 2 e 6 respectivamente).

A Figura 13 mostra a morfologia do biofilme formado por S. mutans após 12 horas de crescimento nas condições testadas. Utilizando-se glicose, frutose ou maltose como fonte de carbono, a formação de uma camada homogênea de biofilme, ocupando totalmente o fundo do poço, pode ser visualizada. No caso do uso da sacarose, uma total ocupação do fundo do poço também ocorre, apesar da aparência da superfície do biofilme formado ser irregular. Este aspecto pode ser devido a pelo menos em parte, à produção de polissacarídeos extracelulares quando a sacarose é utilizada como fonte de carbono, afetando a morfologia celular (MORO et al., 1986). A xilose, assim como o meio de cultivo não suplementado por nenhuma fonte de carbono, não promoveu uma total ocupação do fundo do poço, reforçando a idéia sugerida por Paulino e colaboradores (PAULINO et al., 2003) de que a bactéria não metaboliza este carboidrato.

A adição de crescentes concentrações de flúor ao meio suplementado com glicose, frutose e maltose produziram um efeito muito similar, com uma gradual redução da cobertura do fundo do poço (Figura 13), surgindo assim pequenas áreas 


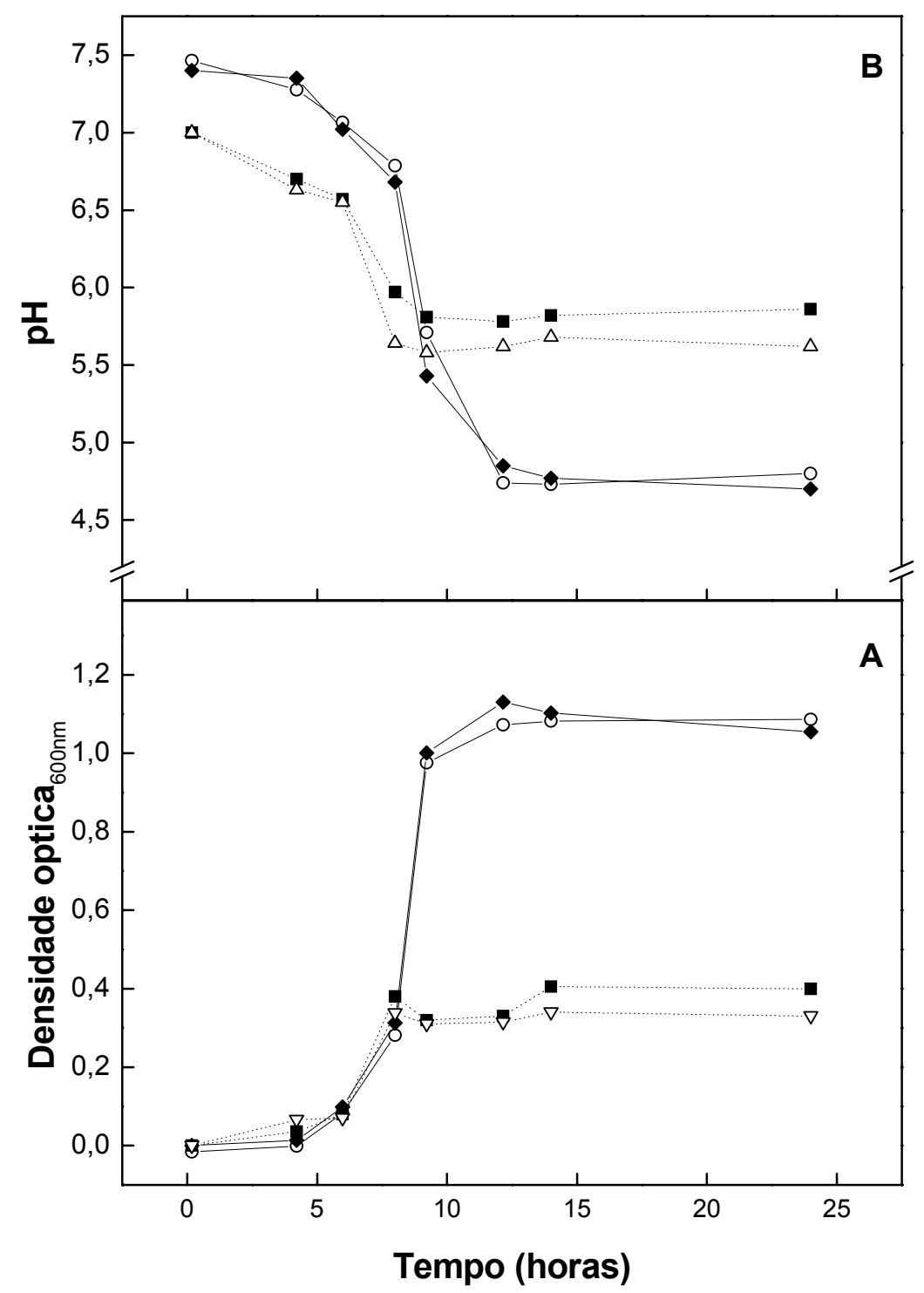

Figura 9. Curvas de crescimento de $S$. mutans mostrando a variação da densidade óptica em 600nm (A) e pH (B) em função do tempo de cultivo em meio TSB ( -$)$ ou meio completo (- - - ): sem fonte de carbono $(\triangle)$; na presença de $13 \mathrm{mmol} / \mathrm{L}$ de glicose $(O) ; 13$ $\mathrm{mmol} / \mathrm{L}$ xilose $(\mathbf{a})$ ou mistura de $13 \mathrm{mmol} / \mathrm{L}$ glicose com $13 \mathrm{mmol} / \mathrm{L}$ xilose $(\diamond)$. Cada ponto é a média de três experimentos com uma variação inferior a $5 \%$. 


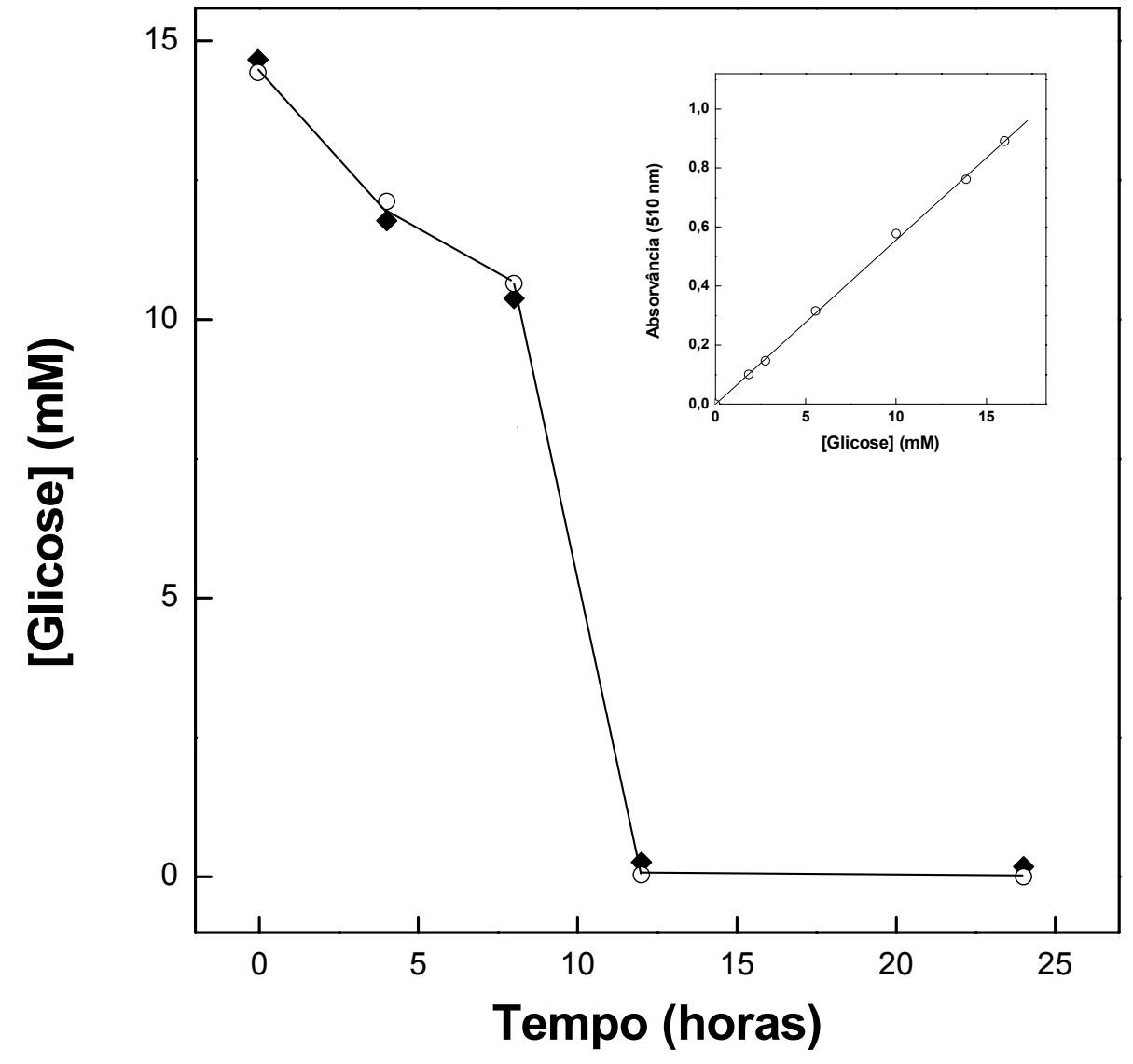

Figura 10. Concentração da glicose em função do tempo de crescimento de $S$. mutans em meio TSB suplementado $(\bullet)$ ou não $(O)$ com $13 \mathrm{mmol} / \mathrm{L}$ xilose. Inserção: curva padrão de calibração usando um Kit de ensaio de glicose (PAULINO et al., 2003). Cada ponto é a média de três experimentos com uma variação inferior a $5 \%$. 


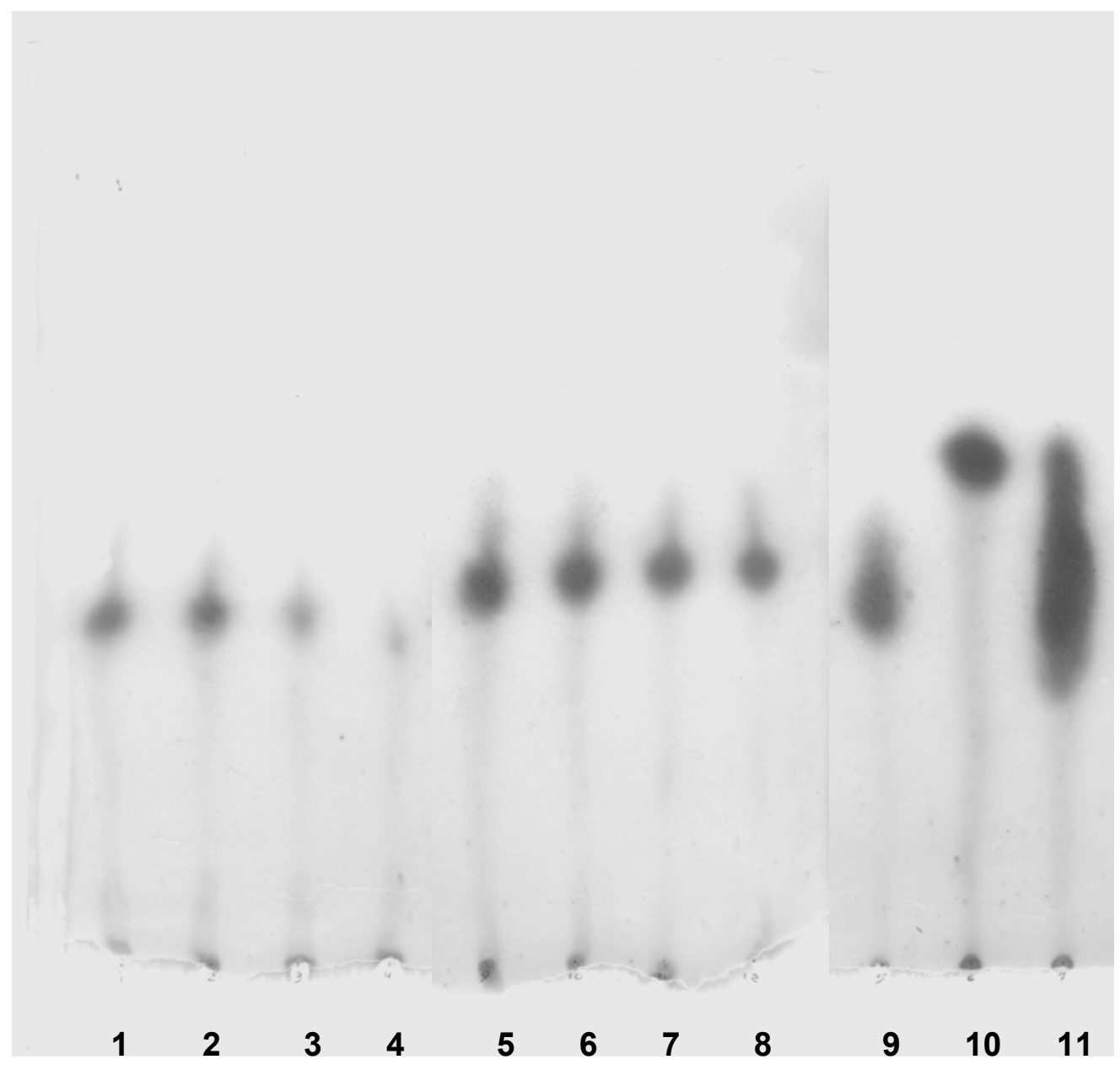

Figura 11. TLC dos carboidratos utilizados como referência (xilose e glicose) e do meio de cultura de $S$. mutans após crescimento em meio suplementado com $13 \mathrm{mmol} / \mathrm{L}$ glicose (linhas 1-4) por 4, 8, 12 e 24 horas, respectivamente ou com mistura de $13 \mathrm{mmol} / \mathrm{L}$ glicose e $13 \mathrm{mmol} / \mathrm{L}$ xilose (linhas 5-8), por 4, 8, 12 e 24 horas, respectivamente. Linhas 9, 10 e 11 contêm padrões de glicose, xilose e mistura de glicose com xilose, respectivamente. 
com um gradual desaparecimento do biofilme acompanhado por um respectivo aumento da concentração de flúor (1, 3 e $5 \mathrm{mmol} / \mathrm{L})$.

O efeito de flúor na formação do biofilme em presença de sacarose foi menos intenso, visto que com $5 \mathrm{mmol} / \mathrm{L}$ de $\mathrm{NaF}$, a cobertura do fundo do poço foi menos significante, além do que, diferentemente dos outros carboidratos, não foi possível a visualização de colônias isoladas. Aparentemente, a bactéria torna-se menos sensível ao flúor quando seu crescimento ocorre na presença de sacarose. Quando a xilose é usada como fonte de carbono, uma redução no crescimento pode ser observada claramente e, embora menos significante, o crescimento na presença deste carboidrato e flúor é menor, como já descrito anteriormente. O mesmo resultado foi observado quando nenhuma fonte de carbono foi empregada, favorecendo a conclusão de que o metabolismo de fontes de carbono intracelular é prejudicado pelo flúor, possivelmente pelo bloqueio da enzima enolase, como descrito por Cox e colaboradores (COX et al., 1999).

A condição na qual a bactéria consegue multiplicar-se na presença de flúor se deve ao fato de que, em pH neutro (em torno de 7), a dose inibitória deste haleto é de $10 \mathrm{mmol} / \mathrm{L}$, ao passo que, quando o meio torna-se mais ácido, a dose necessária para promover uma inibição no crescimento da bactéria cai cerca de 10 vezes ( $\mathrm{pH} 5,5)$. Assim, o fato da bactéria conseguir baixar o $\mathrm{pH}$ do meio na medida em que ela metaboliza os carboidratos, explica seu crescimento inicial em presença de flúor e na medida que o pH baixa, concentrações de flúor antes pouco eficazes, ganham um aumento de 10 vezes na sua capacidade de inibir o catabolismo das células (FEJERSKOV et al., 1996). Esta inibição pode inclusive ser notada, haja vista a diminuição da formação do biofilme (Figura 13).

\subsubsection{Avaliação da capacidade acidogênica de $S$. mutans em meio planctônico após adição de diferentes carboidratos - pulso de carboidratos.}

A Figura 14 mostra o decaimento do pH após a adição de diferentes açúcares à suspensão celular de $S$. mutans. Um intenso e similar decréscimo do $\mathrm{pH}$ pode ser observado nos 20 minutos iniciais da incubação com glicose, frutose, maltose ou sacarose. Após esta inicial e intensa liberação ácida, uma fase de decaimento lenta do $\mathrm{pH}$ é observada, continuando até os 120 minutos do final da incubação. Este decaimento do $\mathrm{pH}$ se deve a metabolização dos açúcares através da via glicolítica, 


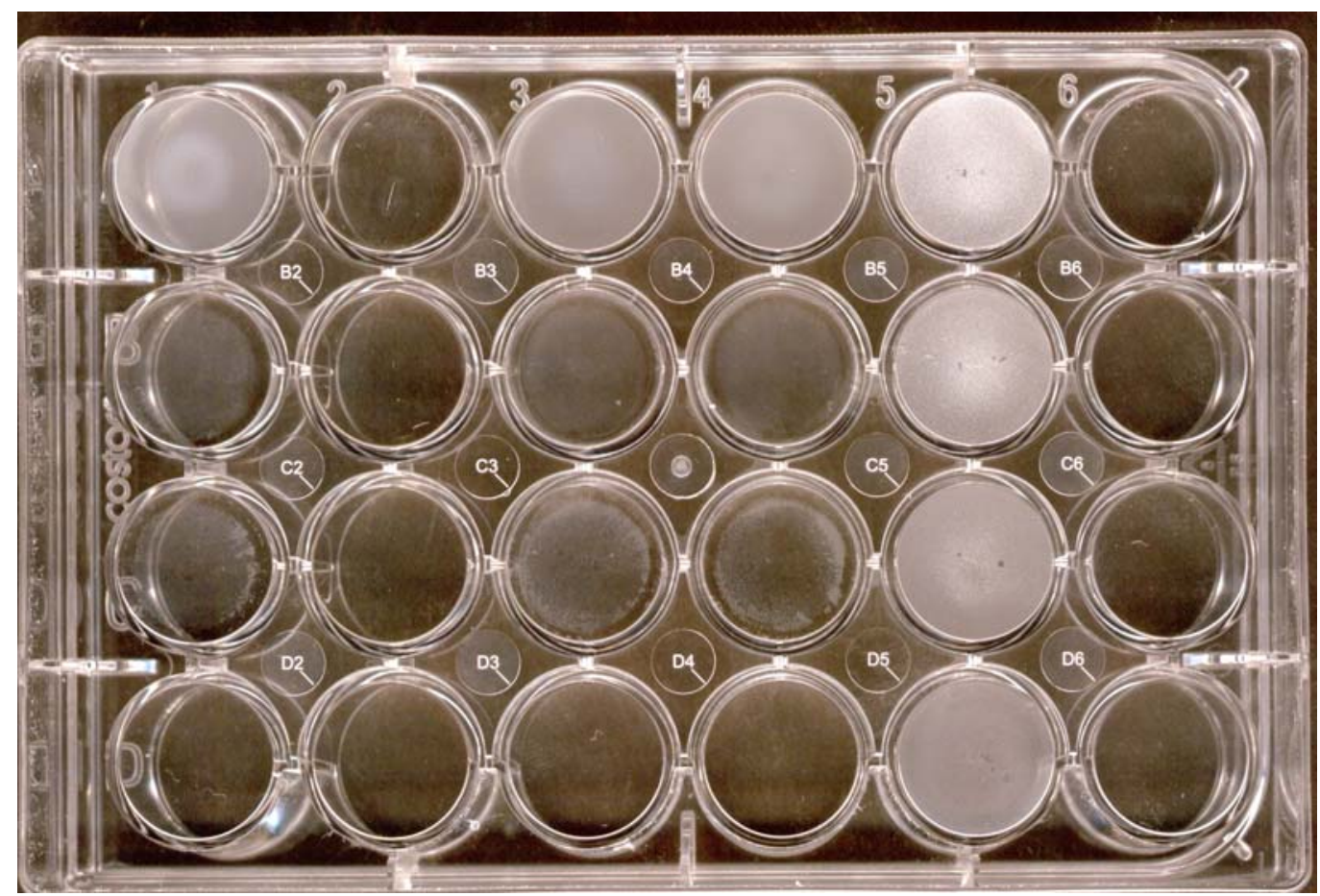

Figura 12. Placa de cultura (24 poços) após 12 horas de crescimento de $S$. mutans em meio completo suplementado com $1 \%(\mathrm{p} / \mathrm{v})$ de carboidrato. Coluna 1, maltose; 2 , xilose; 3 , glicose; 4 , frutose; 5 , sacarose e 6 , controle (sem fonte de carbono). Linha A, sem flúor; B, $\mathrm{C}$ e $\mathrm{D}$ com 1,3 e $5 \mathrm{mmol} / \mathrm{L}$ de $\mathrm{NaF}$, respectivamente. 


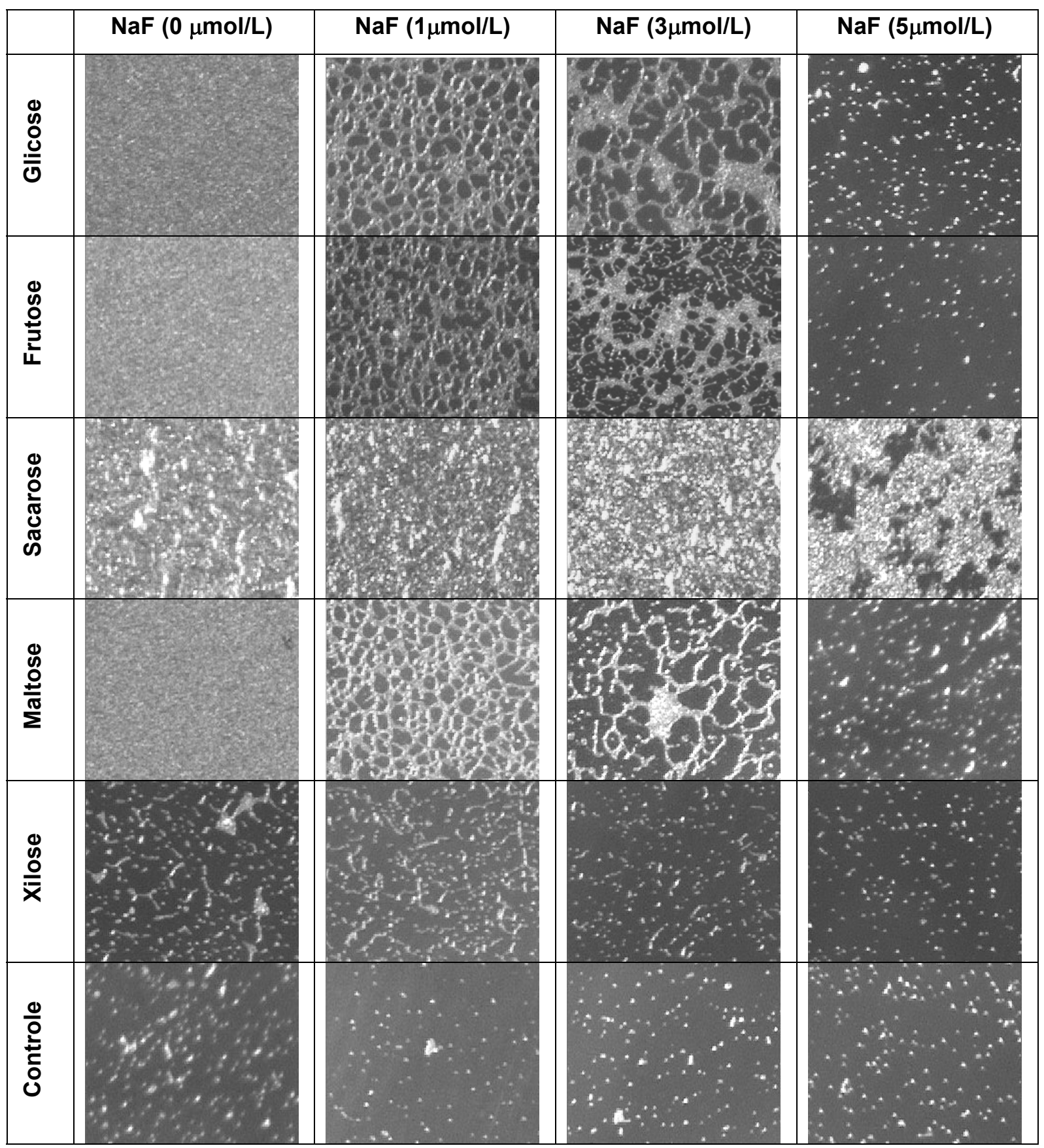

Figura 13: Fotomicrografia do biofilme formado por S. mutans após crescimento durante 12 horas em meio completo suplementado com $1 \%$ de carboidrato $(p / v)$ e/ou $\mathrm{NaF}(1,3$ e 5 $\mathrm{mmol} / \mathrm{L}$ ) como indicado. O controle refere-se ao biofilme formado em meio completo não suplementado com carboidrato (aumento de $100 \mathrm{X}$ ). 
com posterior produção de ácidos orgânicos que tornam o ambiente ácido, o que é frequentemente observado em meios de cultivo deste microrganismo (PAULINO et al., 2003).

Quando a xilose é utilizada como fonte de carbono, a acidificação é menos intensa e alcança valores similares ao do controle (sem adição de carboidrato), reforçando a idéia de que a xilose não promove o crescimento de $S$. mutans, não sendo metabolizado por este microrganismo (PAULINO et al., 2003). A acidificação inicial observada pode ser devida a um mecanismo alternativo de entrada de açúcar realizado por este organismo (denominado "uptake" ou importe), que envolve um antiporte de $\mathrm{H}^{+}$(HAMILTON, 1987). Visto que a xilose não é metabolizada pela bactéria, a produção de energia diminui e a acidificação para. De fato, na ausência de combustível metabólico, o pH diminui uniformemente e alcança valores similares ao observado no pulso com xilose (Figura 14). Isto reforça a observação de Paulino e colaboradores (PAULINO et al., 2003) onde o crescimento e acidificação no meio de cultivo, sem a adição de carboidrato é insignificante, possivelmente por causa da restrita quantidade de açúcar fermentável disponível na forma de reserva intracelular, como já descrito anteriormente (SPATAFORA, 1995). Estas reservas podem ser suficientes para iniciar a acidificação, mas elas são depletadas. Então a diminuição do pH nos experimentos controle e na xilose é devida à eliminação de ácidos produzidos através do metabolismo de reservas de combustível intracelular, provavelmente polissacarídeos (WEGMAN et al., 1984).

Estes resultados mostram que a sacarose não é mais acidogênica que a glicose ou frutose, visto que uma acidificação similar do ambiente extracelular ocorre de forma semelhante a estes carboidratos. A cariogenicidade deste açúcar está também relacionada com a indução da síntese de polissacarídeos extracelulares insolúveis, envolvidos na adesão bacteriana à superfície do dente e conseqüente formação de biofilme, conforme descrito por Rola (ROLA, 1989).

\subsection{Caracterização fotoquímica dos agentes fotossensíveis e seu emprego na TFD sobre $S$. mutans e fibroblastos}

Estudos envolvendo a utilização da TFD com fins bactericidas são realizados desde a década de 80 (VENEZIO et al., 1985) e sua aplicação tem obtido resultados promissores (SHAWAR \& COOPER 1990; WILSON et al., 1993; BURNS et al., 


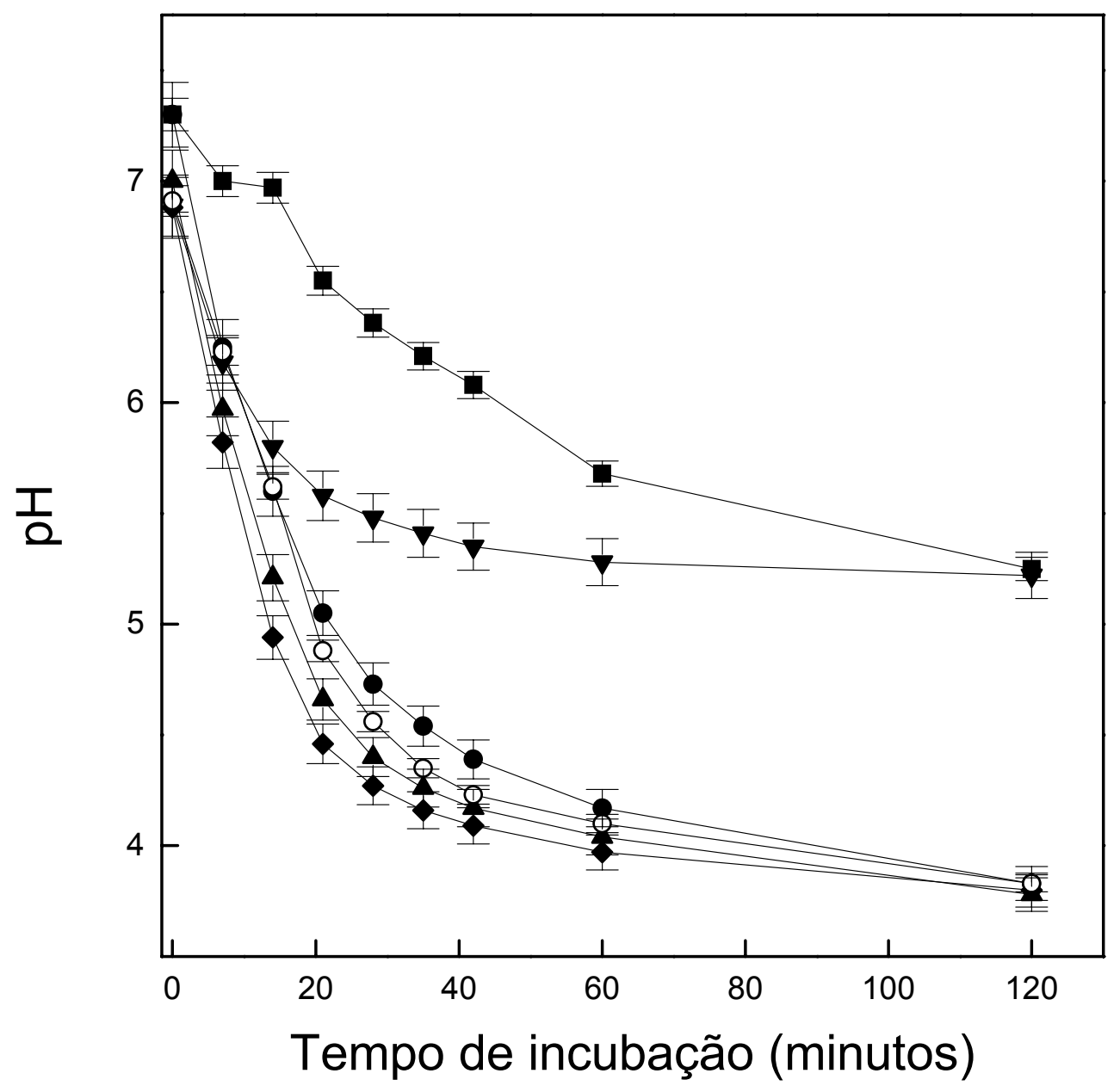

Figura 14: $\mathrm{pH}$ da suspensão celular de $S$. mutans suplementado com diferentes fontes de carbono. A suspensão celular foi suplementada com: $(\boldsymbol{O})$ Glicose; $(\boldsymbol{\Delta})$ Frutose; ( $\boldsymbol{\nabla})$ Xilose; ( ) Maltose; (O) Sacarose e ( $\mathbf{a})$ sem nenhuma fonte de carbono. Os dados representam a média de valores $(n=3)$ e as barras de erros representam o desvio padrão. 
1995; PAULINO et al., 2005). Assim, padronizadas as condições de crescimento da bactéria, a terapia fotodinâmica passou a ser o foco principal de estudo neste trabalho. E, a fim de se promover um efeito bacteriostático in vitro no $S$. mutans, experimentos empregando-se diferentes agentes fotossensíveis foram realizados e de forma comparativa, estes estudos foram aplicados sobre uma cultura in vitro de fibroblastos.

Desta forma, inicialmente os agentes fotossensíveis foram avaliados quanto aos seus aspectos fotoquímicos e fotofísicos para que posteriormente pudessem ser empregados corretamente na inativação da bactéria $S$. mutans com o auxílio da TFD.

\subsubsection{Rose bengal}

\subsubsection{Caracterização fotoquímica do Rose bengal}

O Rose Bengal, também chamado de Rosa de bengala é a 4,5,6,7-tetracloro2',4',5',7'-tetraidrofluoresceína, um corante comumente utilizado como colírio, em consultórios oftalmológicos, para identificação de células da córnea ou células com lesões. Entretanto, devido às elevadas taxas de toxicidade apresentadas por este corante, ele tem sido substituído pela flouresceína sódica ou indocioanina verde especialmente nas aplicações na clínica oftalmológica (SINGH, et al., 2004).

Além disso, o Rose bengal é um agente fotossensível muito empregado experimentalmente na TFD, este agente fotossensível possui uma grande capacidade de se localizar na membrana plasmática de mamíferos, formando altas quantidades de oxigênio singlete e levando estas células a morte e, por esta razão, seu emprego na clínica com finalidade terapêutica tem sido evitada (PEDERSEN et al., 1977; DAHL et al., 1988; KOCHEVAR et al., 1994; WACHTER et al., 2003; PAULINO et al., 2005).

Quanto aos seus aspectos fotoquímicos, estudos já realizados demonstram uma banda de absorção de luz na faixa de 500 a $600 \mathrm{~nm}$ e, de fato, na Figura 15 está mostrado o espectro de absorção do Rose Bengal (4,0 $\mu \mathrm{mol} / \mathrm{L}$ em PBS), cuja banda de absorção no espectro do visível (450 - $600 \mathrm{~nm})$ é semelhante ao descrito por Kochevar e colaboradores (KOCHEVAR et al., 1996) e Stiel e colaboradores (STIEL et al., 1996). 
O espectro de absorção da droga é coincidente com o espectro de emissão da luz irradiada pelo fotopolimerizador de resina odontológica (filtro original do fabricante, 400 - $500 \mathrm{~nm}$ ), o que permite a fotossensibilização do corante com a luz disponível.

A caracterização fotoquímica do Rose bengal em relação ao rendimento quântico de oxigênio singlete, emissão de fluorescência, absorção de transiente, decaimento triplete e emissão de fosforescência não foram realizados visto que este corante foi empregado nos experimentos com TFD somente como uma droga modelo pois, seus rendimentos quânticos para a produção de espécies reativas de oxigênio já são descritos na literatura (LARKIN et al., 2002; RODRIGUÉZ et al., 2004).

\subsubsection{Efeito da TFD sobre $S$. mutans e fibroblastos utilizando-se o Rose bengal}

A Figura 16 indica claramente que a partir da fotoirradiação de uma suspensão contendo o corante, na presença de $S$. mutans, realizada com o fotopolimerizador $\left(325,1 \mathrm{~mJ} / \mathrm{cm}^{2}\right.$ que corresponde a 30 segundos de irradiação com a amostra localizada a $11,2 \mathrm{~cm}$ da ponteira do fotopolimerizador), deve estar ocorrendo a produção de espécies reativas de oxigênio que irão induzir a inativação da bactéria. Assim, pode-se observar que, no escuro (toxicidade "per se"), somente concentrações acima de 5,0 $\mu \mathrm{mol} / \mathrm{L}$ são tóxicas para a bactéria, ao passo que, com uma concentração de corante 5 vezes menor e após uma dose de luz (30 segundos) é possível inativar todos os microrganismos viáveis.

Além disso, comparativamente, no inserto da Figura 16 pode ser observado que para os fibroblastos é requerida uma concentração de aproximadamente 1 $\mu \mathrm{mol} / \mathrm{L}$ de Rose bengal para promover uma morte celular de aproximadamente $10 \%$ após a irradiação da mesma dose de luz e, no escuro, concentrações deste corante abaixo de $5 \mu \mathrm{mol} / \mathrm{L}$ são inertes à viabilidade celular.

\subsubsection{Protoporfirina IX}

\subsubsection{Caracterização fotoquímica e fotofísica da Protoporfirina IX e seu emprego na TFD sobre S. mutans e fibroblastos}




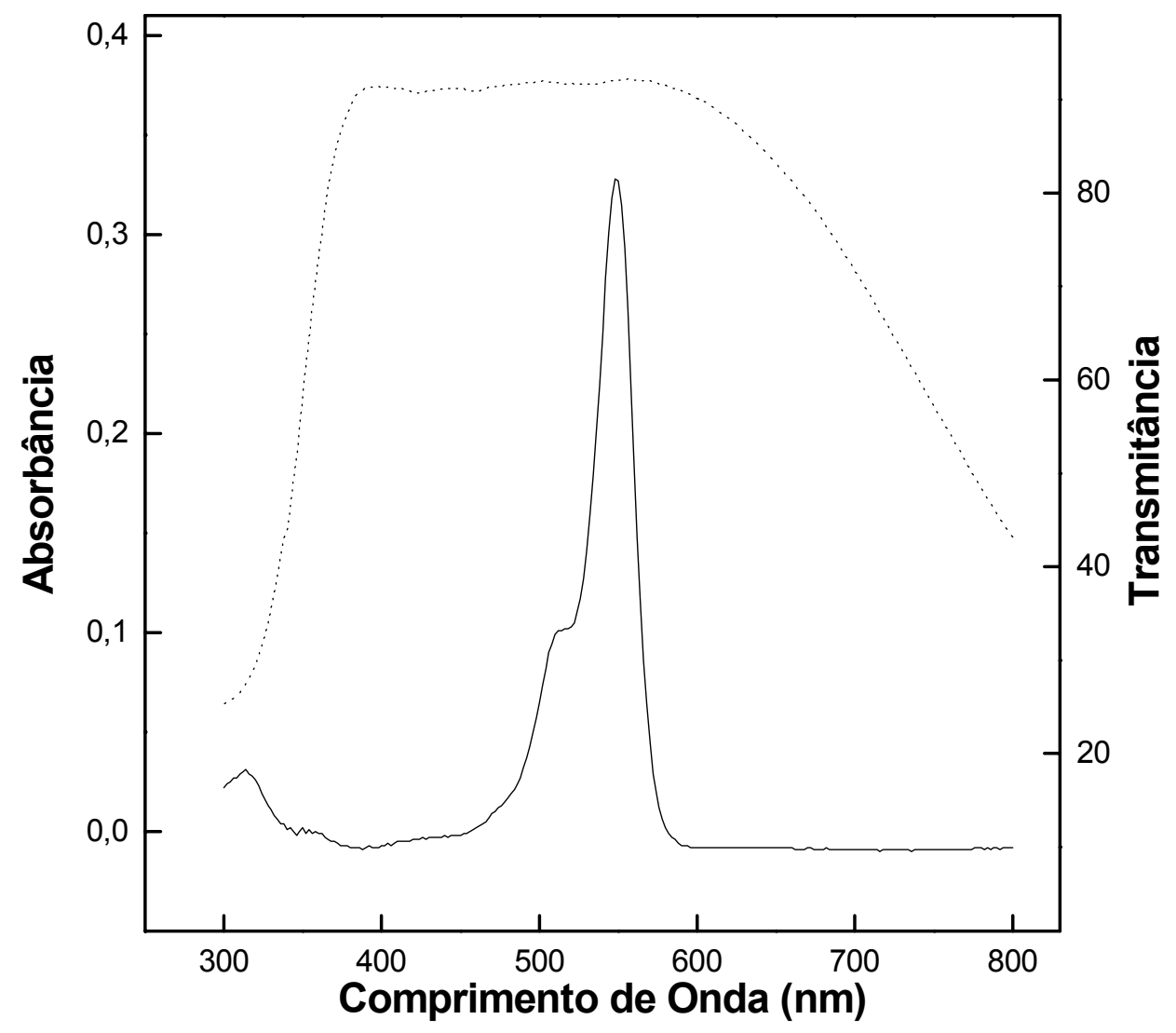

Figura 15: (__ Espectro de absorção do Rose bengal $4.0 \mu \mathrm{mol} / \mathrm{L}$ em tampão salino pH 7.4 (PBS) e (------) espectro de transmitância do filtro original do fotopolimerizador de resina odontológica. 


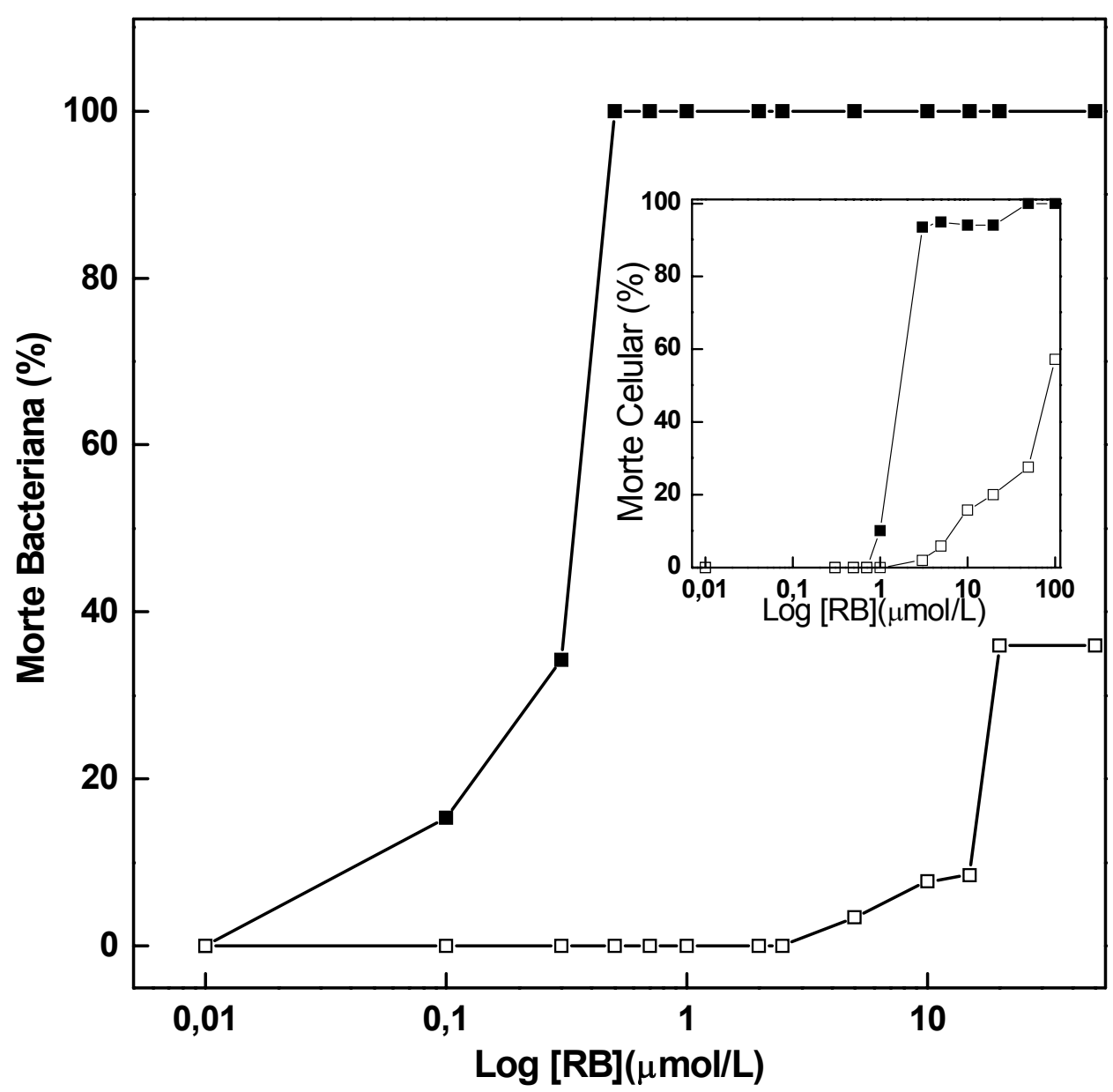

Figura 16: Viabilidade de $S$. mutans na presença de variáveis concentrações de Rose bengal. A bactéria $\left(10^{3}\right.$ UFC) foi incubada com o corante durante 10 minutos e incubada em meio de cultivo TSA durante 36 horas a $37^{\circ} \mathrm{C}$ na ausência de luz com $(\bullet)$ ou sem (०) irradiação de luz pelo fotopolimerizador. Inserção: viabilidade dos fibroblastos na presença de variáveis concentrações de Rose bengal. As células $\left(10^{6}\right)$ foram incubadas com o corante durante 10 minutos e crescidas em DEMEN/F-12 por 24 horas no escuro com (घ) ou sem ( $\square$ ) irradiação com o fotopolimerizador. 
O espectro de absorção da PPIX em meio homogêneo (tampão fosfato, pH $7,4)$ foi determinado utilizando uma concentração de 5,0 $\mu \mathrm{mol} / \mathrm{L}$. Seu espectro de absorção apresenta-se com bandas bastante alargadas (Figura 17) devido ao fato deste corante não ser muito solúvel em meio aquoso.

Comparado ao espectro observado pela PPIX em água, na presença de solventes orgânicos há um grande deslocamento das bandas de absorção do corante, o que é inclusive descrito por outros autores (BRANCALEON, et al., 2004). Assim, um estudo para avaliar o deslocamento das bandas provocado por solventes de diferentes polaridades foi realizado e os resultados estão mostrados na Figura 17.

Na Figura 17, pode-se observar que o pico de absorção máxima de luz pela

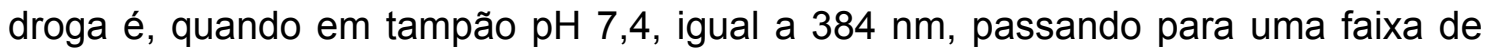
menor energia (396 a $420 \mathrm{~nm}$ ) quando o corante está na presença de solventes orgânicos (Tabela 2). Aparentemente, a variação ocorrida na banda de absorção (406 e $420 \mathrm{~nm}$ ), na presença de solventes orgânicos está relacionada a um decréscimo da constante dielétrica (BONNETT, 1988).

Observa-se também que a luz emitida pelo fotopolimerizador de resina odontológica é coincidente com a região de absorção de luz da PPIX em todos os tampões apresentados na Figura 17.

De fato a redução da constante dielétrica pode afetar o tempo de vida das espécies singlete e triplete que por sua vez afeta a quantidade (rendimento quântico) de florescência e por conseqüência a quantidade de ERO's.

Tabela 2: Valores dos picos de absorção máxima do corante $\operatorname{PPIX}(0,2 \mu \mathrm{mol} / \mathrm{L})$, dissolvido em diferentes solventes, determinada conforme descrito em Material e Métodos.

\begin{tabular}{lcc}
\hline Solvente & Constante Dielétrica & Absorção Máxima (nm) \\
\hline Tampão $(\mathrm{pH} \mathrm{7,4)}$ & 80,0 & 384 \\
DMSO & 47,2 & 406 \\
Acetona & 20,8 & 416 \\
Diclorometano & 20,7 & 420 \\
\hline
\end{tabular}

Ainda na Figura 17 é mostrado o espectro de absorção de luz, na região do visível (300 - $800 \mathrm{~nm}$ ), pela PPIX em diferentes sistemas tamponantes e orgânicos. A banda de absorção observada de 370 - 420 nm é característica para este tipo de 


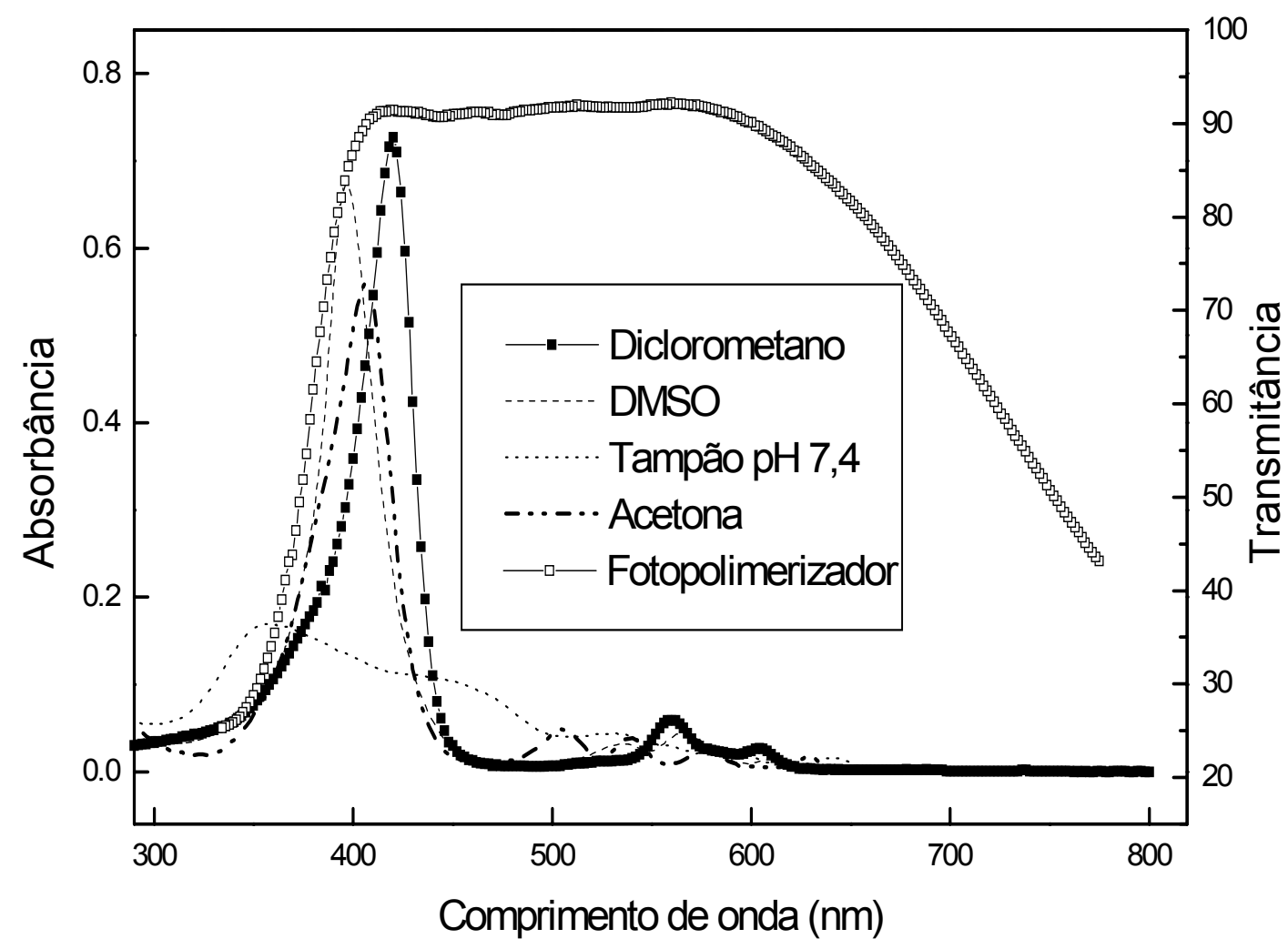

Figura 17: Espectros de absorção do corante PPIX na concentração de 3,0 $\mu \mathrm{mol} / \mathrm{L}$ e de emissão (Transmitância) da luz emitida pelo fotopolimerizador, realizado conforme descrito em Material e Métodos, item 3.7.1. Uma amostra de tampão fosfato ( $\mathrm{pH} 7,4)$, DMSO, Diclorometano e Acetona, todos sem o corante foi utilizada para calibração do equipamento (branco). 
composto (SCOLARO et al., 2002) e, de forma semelhante ao ocorrido com o corante Rose bengal, a luz emitida pelo fotopolimerizador de resina odontológica sobrepõe à região de absorção de luz deste derivado porfirínico.

O rendimento quântico de fluorescência para a PPIX foi determinado utilizando-se como padrão a violeta de cresil em etanol $\left(\Phi_{F}=0,54\right)$ sendo o rendimento quântico apresentado pelo corante PPIX em meio homogêneo de 0,16 e para uma solução padrão de PPIX em acetona é de 0,12.

Quanto à emissão de fluorescência, a PPIX em meio homogêneo, apresentou emissão máxima em 647 e 688 nm (Figura 18).

A Figura 19 mostra o espectro de absorção do transiente realizado por fotólise por pulso de laser, onde as regiões com absorbância acima de zero apresentam absorção triplete. Para o fotossenssibilizador PPIX, este perfil varia de 400 a 700 nm. A depleção da banda de absorção do estado fundamental da PPIX em meio homogêneo apresenta-se em $360 \mathrm{~nm}$. Já os tempos de vida do estado excitado triplete para PPIX foi de $0,26 \mu$ s em meio homogêneo (resultado não mostrado).

O coeficiente de absortividade molar $\left(\varepsilon=2,7.10^{4} \mathrm{~cm}^{-1} \mathrm{~mol}^{-1} \mathrm{~L}\right)$ do corante PPIX foi determinado no cumprimento de onda de $452 \mathrm{~nm}$, para a droga presente em meio tamponado (tampão PBS, pH 7,4), utilizando a Lei de Lambert-Beer. As medidas foram feitas em cubetas de quartzo com $1,0 \mathrm{~cm}$ de caminho óptico, conforme descrito em Material e Métodos.

A intensidade máxima de fosforescência no tempo 0 foi determinada pela regressão exponencial e os tempos de vida de oxigênio singlete foram determinados pelo tratamento do ajuste da curva (resultado não mostrado). O valor do rendimento quântico de produção de oxigênio singlete produzido pelo corante PPIX e feoforbide-a, determinados são apresentados na Tabela 3. O Feoforbide-a, conforme descrito em Material e Métodos, foi empregado como corante padrão

Tabela 3: Valores de rendimento quântico de oxigênio singlete para a PPIX em tampão PBS ( $\mathrm{pH} 7,4)$, comparação com Feoforbide-a, conforme Material e Métodos.

\begin{tabular}{cc}
\hline Composto & $\Phi_{\Delta}$ \\
\hline Feoforbide-a & 0,59 \\
PPIX em tampão & 8,42 \\
\hline
\end{tabular}




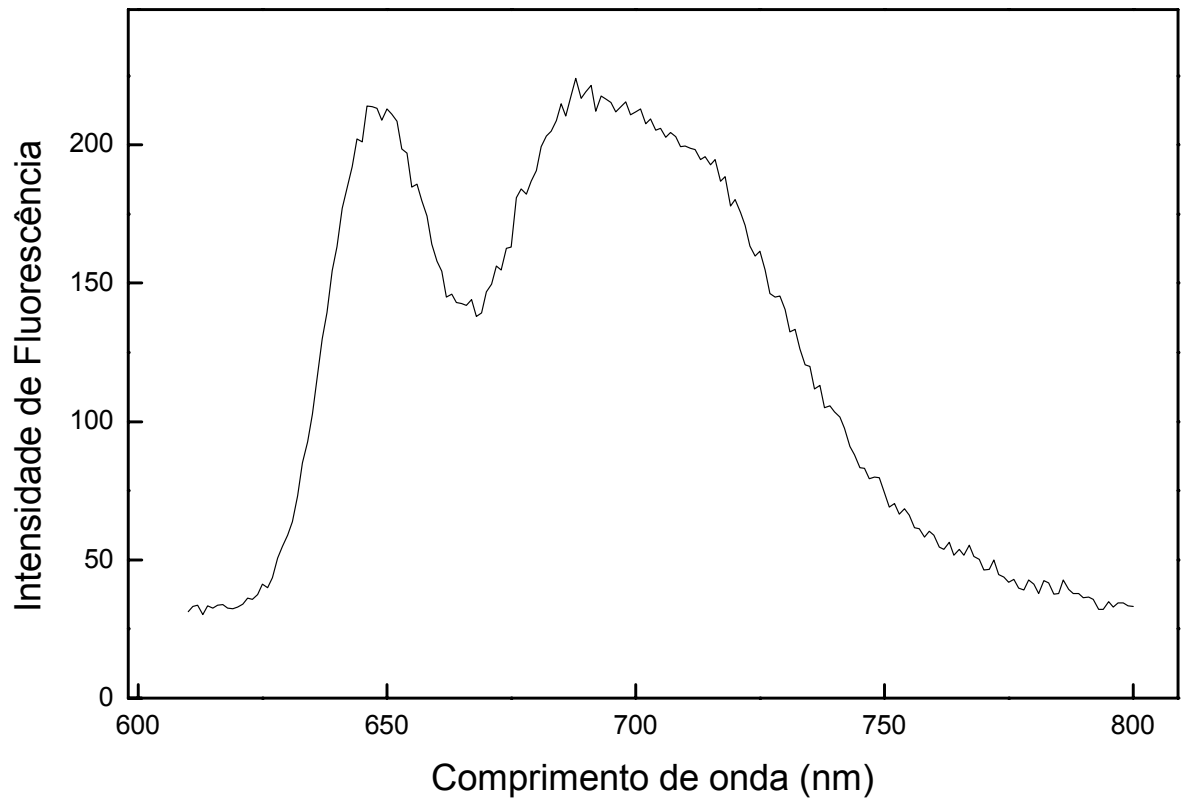

Figura 18: Espectro de emissão de fluorescência do corante PPIX. Excitação fixa em 452 $\mathrm{nm}$ com leitura a partir de 600 a até $800 \mathrm{~nm}$, conforme descrito em Material e Métodos. 


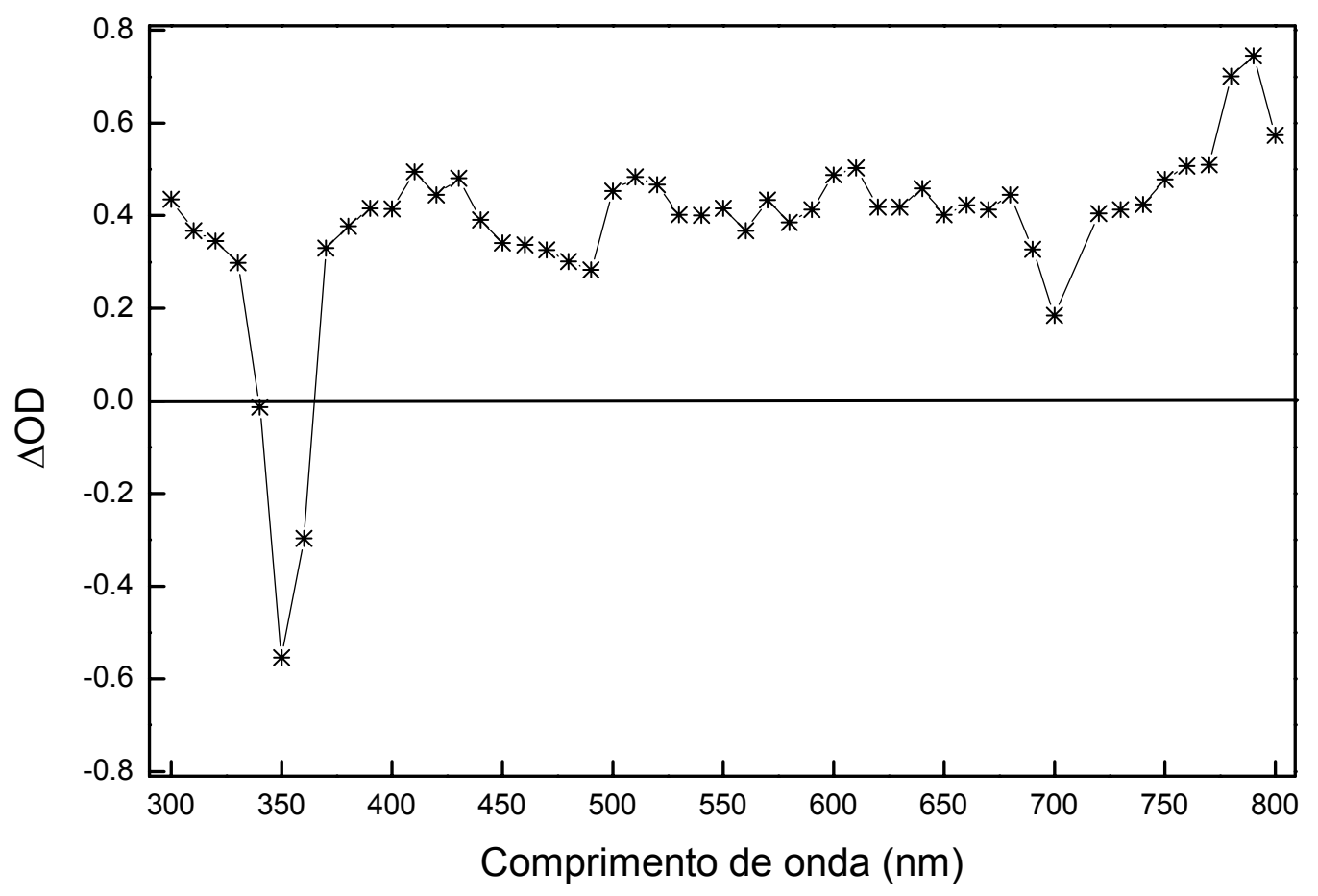

Figura 19: Espectro de absorção do transiente do corante PPIX $(0,2 \mu \mathrm{mol} / \mathrm{L}), 0,21 \mu \mathrm{s}$ após a excitação por pulso de laser em $355 \mathrm{~nm}$, mostrando a absorção máxima do triplete e o fotobranqueamento do estado fundamental, centrado em $350 \mathrm{~nm}$. 


\subsubsection{Efeito da TFD sobre $S$. mutans e fibroblastos utilizando-se a Protoporfirina IX}

Conforme apresentado na Figura 17, utilizando-se o filtro original do fotopolimerizador de resina odontológica é possível emitir uma luz na qual a PPIX possa absorver (400 - $500 \mathrm{~nm}$ ), podendo gerar assim espécies reativas de oxigênio. Para isto, a PPIX foi adicionada a uma suspensão celular, seguida por uma irradiação com o fotopolimerizador.

A PPIX é uma molécula no estado singlete basal que, quando irradiada, produz através de um cruzamento intersistemas, uma quantidade significativa de espécies tripleto no estado basal. Já o oxigênio molecular, sempre presente em meios biológicos, normalmente serve como bom aceptor de energia de moléculas no estado tripleto (ERICSON et al., 2003).

Assim, fundamentado nos princípios da TFD e, conforme mostrado na Figura 20 , é possível inativar a bactéria com concentrações do corante a partir de 0,2 $\mu \mathrm{mol} / \mathrm{L}$, utilizando-se para isto dose de energia de $325,1 \mathrm{~mJ} / \mathrm{cm}^{2}$. Já a toxicidade no escuro da droga (emprego da droga sem utilizar a luz, toxicidade "per se" do corante) só se evidencia em concentrações superiores a 3,0 $\mu \mathrm{mol} / \mathrm{L}$. Esta ordem de grandeza para a concentração tóxica de corantes é normalmente encontrada em corantes fotossensíveis endógenos tais como a protoprofirina (TREMBLAY et al., 2002).

Adicionalmente, os resultados apresentados no inserto da Figura 20 indicam que os fibroblastos, quando submetidos às mesmas condições de TFD que as bactérias, apresentam um efeito de morte celular (toxicidade após a TFD), em torno de $30 \%$ (para $0,5 \mu \mathrm{mol} / \mathrm{L}$ de Protoporfirina IX), chegando a um máximo de aproximadamente $60 \%$ de toxicidade quando utilizada uma concentração de 50 $\mu \mathrm{mol} / \mathrm{L}$ de PPIX. Além disso, a toxicidade do corante para os fibroblastos quando não irradiados (toxicidade "per se"), somente se torna significativa em concentrações superiores à $5 \mu \mathrm{mol} / \mathrm{L}$ de Protoporfirina IX.

\subsubsection{Zinco ftalocianina}

As ftalocianinas compreendem uma das principais classes de agentes fotossensibilizantes utilizados na TFD. A Zinco ftalocianina é uma das 


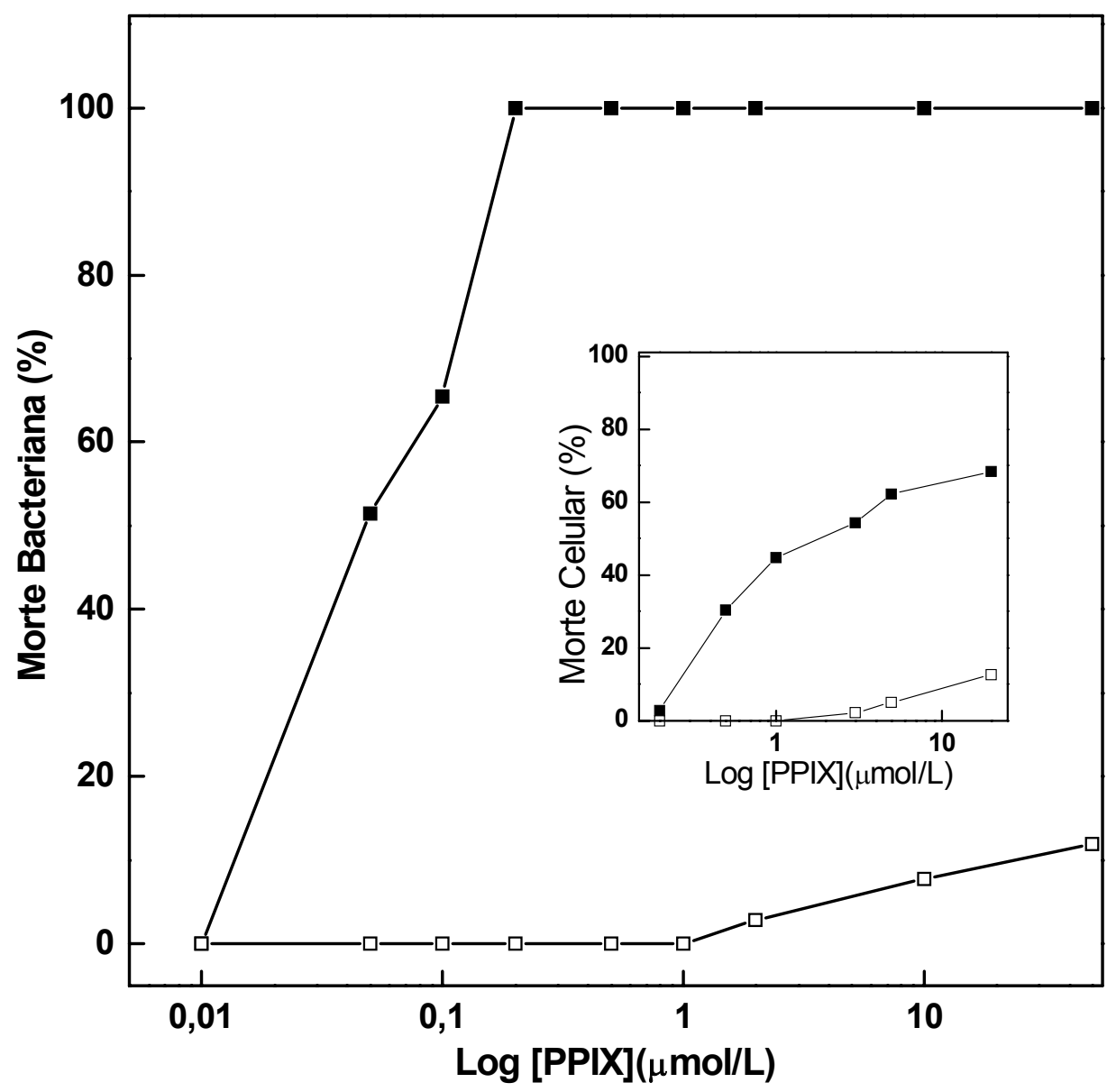

Figura 20. Viabilidade de $S$. mutans na presença de variáveis concentrações de Protoporfirina IX. A bactéria $\left(10^{3}\right.$ UFC) foi incubada com PPIX durante 10 minutos e incubada em meio de cultivo TSA durante 36 horas a $37^{\circ} \mathrm{C}$ na ausência de luz com $(\bullet)$ ou sem (०) irradiação de luz pelo fotopolimerizador. Inserção: viabilidade dos fibroblastos na presença de variáveis concentrações de PPIX. As células $\left(10^{6}\right)$ foram incubadas com o corante durante 10 minutos e crescidas em DEMEN/F-12 por 24 horas no escuro com (a) ou sem ( $\square$ ) irradiação com o fotopolimerizador. 
metaloftalocianinas mais empregadas na TFD e devido ao seu caráter lipofílico, ela tem sido incorporada em sistemas de liberação de fármacos lipossolúveis como lipossomos ou micelas (RUCK et al., 1996).

Assim, o ZnPc foi empregado em estudos como agente fotossensível, utilizando-se como agente carreador os lipossomos, os quais foram constituídos pela técnica de sonicação.

\subsubsection{Avaliação da incorporação de ZnPc aos lipossomos: construção, quantificação e localização do corante}

Os lipossomos, como estruturas semelhantes às vesículas, são basicamente constituídos por fosfolipídeos organizados como uma bicamada lipídica concêntrica que contêm um compartimento aquoso em seu interior (OLIVEIRA et al., 2005). Devido a suas características anfipáticas, eles podem incorporar substâncias em seu compartimento aquoso ou na sua bicamada lipídica. Considerando esta particularidade, os lipossomos podem ser empregados como bons e potenciais carreadores de drogas (ANWER et al., 2000; REDDI et al., 1990), inclusive agentes fotossensíveis como a ftalocianinas (SIBATA et al., 2004).

O coeficiente de absortividade molar do corante ZnPC em meio lipossomal (ZnPc-lipossomo) foi obtido utilizando-se a Lei de Lambert-Beer. As medidas foram feitas em cubetas de quartzo com $1,0 \mathrm{~cm}$ de caminho óptico $\left(\varepsilon_{672 \mathrm{~nm}}=2,3 \cdot 10^{5} \mathrm{~L}_{\mathrm{mol}}{ }^{-1}\right.$. $\left.\mathrm{cm}^{-1}\right)$.

Os lipossomos foram construídos através do método de sonicação (conforme descrito no item 3.6 de Material e Métodos). Já a incorporação do corante aos lipossomos foi avaliada através de análise espectrofotométrica do corante incorporado às vesículas $\left(\varepsilon_{672 \mathrm{~nm}}=2,3 \cdot 10^{5} \mathrm{~L} \cdot \mathrm{mol}^{-1} \cdot \mathrm{cm}^{-1}\right)$. Assim, a Tabela 4 mostra a as concentrações de ZnPc-lipossomo obtidas após montagem das vesículas e incorporação do corante, as medidas de diâmetro médio e as respectivas medidas de polidispersão.

Observa-se que a incorporação de ZnPc aos lipossomos acontece concomitantemente ao aumento da concentração do corante empregada na constituição das vesículas. Além disso, o tamanho médio destas vesículas formadas (na presença de $\mathrm{ZnPc}$ ) é inversamente proporcional ao aumento da concentração do corante incorporado (na faixa de concentração0 de 0 a 32,0 $\mu \mathrm{mol} / \mathrm{L}$ ), exceto para 
a concentração de 50,0 $\mu \mathrm{mol} / \mathrm{L}$ de $\mathrm{ZnPc}$ onde o tamanho médio observado não obedeceu esta inversão de proporcionalidade.

Tabela 4: ZnPc-Lipossomo formado a partir de diferentes concentrações de ZnPc conforme descrito em Material e Métodos, item 3.6. Disposição dos resultados obtidos no espalhamento dinâmico de luz: polidispersão, diâmetro médio e o desvio são referentes a média de 3 medidas realizadas com preparações distintas.

\begin{tabular}{|c|c|c|c|}
\hline \multicolumn{2}{|c|}{$\mathrm{ZnPc}(\mu \mathrm{mol} / \mathrm{L})$} & \multirow[b]{2}{*}{$\begin{array}{l}\text { Diâmetro médio } \\
(\mathrm{nm})\end{array}$} & \multirow[b]{2}{*}{ Polidispersão } \\
\hline $\begin{array}{c}\text { Adicionado ao } \\
\text { ensaio de } \\
\text { preparação }\end{array}$ & $\begin{array}{c}\text { Determinado } \\
\text { nos } \\
\text { lipossomos }\end{array}$ & & \\
\hline- & - & $45,9 \pm 3,67$ & $0,364 \pm 0,03$ \\
\hline 2,0 & $0,79 \pm 0,03$ & $260,8 \pm 62,59$ & $0,913 \pm 0,07$ \\
\hline 4,0 & $1,15 \pm 0,05$ & $250,9 \pm 60,21$ & $0,899 \pm 0,07$ \\
\hline 8,0 & $2,09 \pm 0,10$ & $220,0 \pm 66,00$ & $1,000 \pm 0,08$ \\
\hline 16,0 & $4,42 \pm 0,22$ & $105,5 \pm 8,44$ & $0,356 \pm 0,02$ \\
\hline 32,0 & $3,78 \pm 0,18$ & $93,0 \pm 7,44$ & $0,334 \pm 0,02$ \\
\hline 50,0 & $8,14 \pm 0,40$ & $122,3 \pm 24,46$ & $0,521 \pm 0,04$ \\
\hline
\end{tabular}

Assim, o tamanho médio das vesículas sofre uma alteração quando se forma na presença do corante. Percebe-se também que os altos valores de polidispersão (acima de 0,5), para as vesículas constituídas com 0,79; 1,15 e 2,09 $\mu \mathrm{mol} / \mathrm{L}$ de ZnPc indicam que a população de vesículas de diferentes tamanhos é muito grande, diminuindo a confiabilidade das medidas de diâmetro médio obtidas.

Conforme pode ser observado, na Tabela 4, os valores de polidispersão dos ZnPc-lipossomos de 3,78 $\mu \mathrm{mol} / \mathrm{L}$ foram os menores obtidos $(0,334)$. Além disso, estabilidade destas vesículas pode ser avaliada pelo método espectrofotométrico onde a turbidez e medidas de espalhamento de luz da suspensão foram acompanhadas durante 30 dias (resultados não mostrados). Estes parâmetros não variaram significativamente quando as vesículas foram mantidas sob refrigeração $\left(4^{\circ} \mathrm{C}\right)$ e foi padronizado como período máximo de uso 7 dias após sua preparação.

Neste sentido, após a padronização da metodologia para construção do ZnPc-lipossomo, estas vesículas foram empregadas para avaliação da toxicidade da TFD em células de $S$. mutans e fibroblastos. 
Determinada a concentração de trabalho, uma posterior etapa do processo foi confirmar a incorporação do corante nos lipossomos. Neste sentido, foi realizada uma centrifugação em gradiente de densidade de sacarose (Figura 21), conforme descrito em Material e Métodos (3.6.2).

O gradiente de sacarose permite, através de uma estreita e definida faixa de densidade, separar organelas, estruturas celulares ou pequenas vesículas (como o ZnPc-lipossomo). Assim, uma amostra contendo somente os lipossomos (na ausência do corante), o corante em meio orgânico e uma última contendo os ZnPclipossomo (constituídos de 3,78 $\mu \mathrm{mol} / \mathrm{L}$ do corante) foram aplicados ao gradiente para confirmação da incorporação do corante.

Estes resultados, mostrados na Figura 21A, sugerem que os lipossomos na ausência do corante, estão presentes numa concentração de sacarose ao redor de $18 \%$ (p/p) (densidade de $1,071 \mathrm{~g} / \mathrm{mL}$ ). Por outro lado, o Zinco Ftalocianina praticamente não entra no gradiente, permanecendo nas primeiras frações de baixa concentração de sacarose (Figura 21B). Finalmente para o sistema de ZnPcLipossomo, Figura 21C, o corante e os lipídeos migraram no gradiente de sacarose ao redor de $17 \%$ (p/p) com uma densidade de 1,067 g/mL, indicando que a Zinco Ftalocianina está incorporada aos lipossomos e muito provavelmente intercalado às regiões hidrofóbicas dos fosfolipídeos devido a sua alta hidrofobicidade, conforme anteriormente sugerido por Sibata e colaboradores (SIBATA et al., 2004).

Quanto as características das vesículas formadas, o $\mathrm{ZnPc}$-lipossomo tem uma densidade de $1,067 \mathrm{~g} / \mathrm{mL}$ com um diâmetro médio de aproximadamente 100 $\mathrm{nm}$, ao passo que os lipossomos na ausência de corante $(45 \mathrm{~nm})$ os quais possuem uma densidade média de $1,071 \mathrm{~g} / \mathrm{mL}$. Assim, as vesículas formadas na ausência do corante apresentam-se com uma maior densidade, quando comparadas com as vesículas de $\mathrm{ZnPc}$-lipossomos, possivelmente por mudanças no raio de curvatura das vesículas e sua compactação, causado pela inserção do corante à bicamada de fosfolipídeos.

As medidas de diâmetro foram expressas como valores médios devido à alta polidispersidade presente nas amostras obtidas, visto que os valores de polidispersão indicam um elevado número de diferentes populações (diferentes tamanhos de vesículas). Neste sentido, o ZnPc-lipossomo empregado nos experimentos apresentaram-se com o menor valor de polidispersidade, reflexo de um menor variação no tamanho das vesículas, permitindo uma maior confiabilidade e reprodutibilidade. 


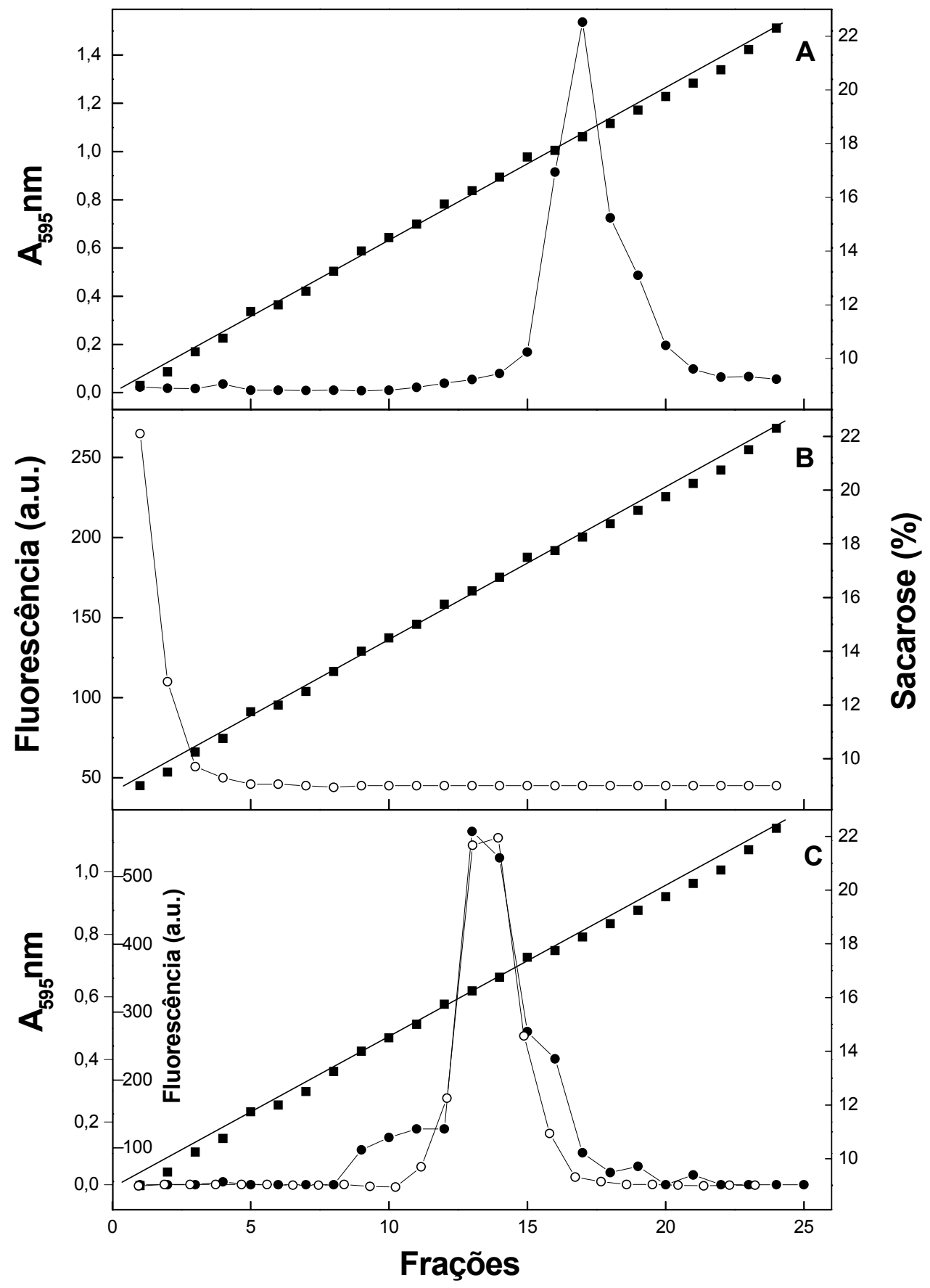

Figura 21: Centrifugação em gradiente de densidade de sacarose: (A) Lipossomo DPPC:LPC (10:1); (B) Zinco ftalocianina em meio orgânico; (C) ZnPc-Lipossomo 3,72 $\mu \mathrm{mol} / \mathrm{L}$. (৫) Fluorescência ZnPc: $\lambda_{\mathrm{ex}}=640, \lambda_{\mathrm{em}}=680 \mathrm{~nm}(\bullet)$ lipídeos: absorbância em $820 \mathrm{~nm}$, referente ao fosfato inorgânico obtido pela hidrólise ácida dos fosfolipídios e ( $\square$ ) \% sacarose determinada por refratometria. 


\subsubsection{Caracterização fotoquímica e fotofísica do Zinco ftalocianina}

Assim como apresentado para o $\mathrm{ZnPc}$, num estudo com a PPIX Chartterjee e colaboradores mostraram que há um deslocamento de bandas de absorção $\left(\lambda_{\text {máx }}\right)$ provocado pela diferença entre a polaridade de solventes como o etanol ou uma solução aquosa. Este deslocamento é também observado nas bandas $Q$ do espectro (600 a $700 \mathrm{~nm}$ ) de porfirinas (CHARTTERJEE et al., 2000). De acordo com a literatura, as bandas $Q$ correspondem aos níveis vibracionais referentes ao primeiro e segundo estado eletronicamente excitado singlete (EICHWURZEL et al., 2000). Em nossos estudos, de forma semelhante ao observado por Chartterjee, observa-se que além do deslocamento observado nas bandas $Q$, a incorporação do corante ZnPC em lipossoma leva também a um deslocamento do pico de absorção máxima, indo de $666 \mathrm{~nm}$ em etanol para $672 \mathrm{~nm}$ em meio lipossomal, como mostrado na Figura 22.

O rendimento quântico de fluorescência do ZnPC em meio lipossomal (ZnPclipossomo) foi determinado utilizando como padrão uma solução de ZnPC em etanol $\left(\Phi_{\mathrm{F}}=0,28\right)$. O rendimento quântico apresentado pelo corante em meio lipossomal foi $\Phi_{\mathrm{F}}=0,19$. Esta diminuição possivelmente ocorre pelo fato do agente fotossensível estar incorporado aos lipossomos especificamente dentro de sua bicamada lipídica, conforme já descrito na literatura (SIBATA et al., 2004).

Através do rendimento quântico de fluorescência é possível determinar se uma molécula tem uma boa emissão de fluorescência. Uma sonda fluorescente ou um marcador de fluorescência precisam ter um alto rendimento de fluorescência $\left(\Phi_{\mathrm{F}}\right.$ $>0,7)$. Entretanto, um agente fotossensível deve ter um baixo rendimento quântico de fluorescência porque ele deve usar a energia absorvida para alcançar o estado triplete excitado, o qual está envolvido com o processo de fotosensibilização de um sistema biológico. Um bom agente fotossensível deve apresentar um alto valor de rendimento quântico para a produção de estados triplete (ver Diagrama de Jablosnki, Esquema 1) (LAKOWICZ, 1984)

O rendimento quântico de fluorescência de uma solução padrão de ZnPc, calculado por um método absoluto, corresponde à 0,28 (OWENS et al., 1998). Este valor, Comparado aos valores obtidos experimentalmente para o ZnPc-lipossomo $(0,19)$. Em consequência disto, observa-se que para o $\mathrm{ZnPc}$-lipossomo há uma 
maior produção de estados tripletos, haja visto que os valores de $\Phi_{\mathrm{F}}$ são menores que os da solução padrão.

O espectro de emissão de fluorescência do fotossenssibilizador ZnPC foi determinado e apresentou emissão máxima em 689 nm (Figura 23). Cada nível de energia de uma molécula está associado a estados de energia vibracional e rotacional. A molécula torna-se excitada pela absorção de uma radiação eletromagnética de freqüência apropriada, que conduz a um nível vibracional excitado de energia correspondente a estados eletrônicos singletes mais elevados. O processo de relaxação térmica, assim como os processos de relaxação vibracional, colisional e rotacional conduzem as moléculas ao mais baixo nível vibracional do estado singlete. É a partir deste estado que pode ocorrer a emissão de fluorescência, onde há a perda da energia absorvida e concomitante retorno do elétron ao seu estado fundamental (BAHERA et al., 1999).

A Figura 24 mostra o espectro de absorção do transiente do ZnPC em meio lipossomal, realizado por fotólise por pulso de laser.

As regiões com absorbância acima de zero apresentam absorção triplete. Para o fotossenssibilizador ZnPC, o estado excitado triplete apresenta um perfil com absorção máxima na região de 420 a $580 \mathrm{~nm}$. A depleção da banda de absorção do estado fundamental da ZnPC em meio lipossomal apresenta-se em 670 e $340 \mathrm{~nm}$. O tempo de vida do estado excitado triplete para o $\mathrm{ZnPc}$ em meio lipossomal foi de $3,95 \mu \mathrm{s}$.

Quanto ao espectro de decaimento do triplete (resultado não mostrado), sabe-se que a eficiência fotodinâmica de um fotossensibilizador depende do seu rendimento quântico e tempo de vida do estado excitado triplete. Assim, quanto maior o tempo de vida do estado excitado, maior será a probabilidade de transferência de energia do agente fotossensível para o oxigênio molecular e consequente produção do oxigênio singlete (FOOTE, 1991).

Nos estudos para determinação de produção de oxigênio singlete para o ZnPc-lipossomo foi utilizado o composto feoforbide-a como padrão de referência, que apresenta um alto valor de rendimento quântico de oxigênio singlete $\left(\Phi_{\Delta}=\right.$ $0,59)$. Os tempos de vida de oxigênio singlete foram determinados através da transferência de energia entre o estado excitado triplete do fotossenssibilizador e o oxigênio molecular presente no meio. A intensidade máxima de fosforescência no tempo 0 foi determinada pela regressão exponencial e os tempos de vida de 
oxigênio singlete foram determinados pelo tratamento do ajuste da curva (resultado não mostrado).

Os valores dos rendimentos quânticos de produção de oxigênio singlete produzidos pelos corantes ZnPC e feoforbide-a, determinados pela equação 1 são apresentados na Tabela 5.

Tabela 5: Valores de rendimento quântico de oxigênio singlete determinados para o composto ZnPc-lipossomo, baseado no agente fotossensível padrão (Feoforbide-a), conforme descrito no item 3.7.5 de Material e Métodos.

\begin{tabular}{lc}
\hline Composto & $\Phi_{\Delta}$ \\
\hline Feoforbide-a & 0,59 \\
ZnPC lipossomal & 0,54 \\
\hline
\end{tabular}

A Figura 25 mostra as características espectrais de absorção e emissão da luz pelo Zinco ftalocianina incorporada aos lipossomos (ZnPc-Lipossomo) e pelo fotopolimerizador de resina odontológica, respectivamente. Para o corante incorporado às vesículas, há uma absorção de luz na faixa de 640 a $690 \mathrm{~nm}$, semelhante aos trabalhos desenvolvidos por Sibata e colaboradores que utilizaram micelas formadas pela mistura de polietilenoglicol 5000 e diestearoil fosfatidil etanolamina (SIBATA et al., 2004).

Em relação à fonte de luz, novamente foi empregado o fotopolimerizador de resina odontológica. Apesar disso, a emissão de luz pelo equipamento não é condizente com a faixa de absorção de luz do corante agora empregado (ZnPclipossomo). Assim, um filtro com características para emissão de luz (600 a 700 nm) foi instalado no equipamento, em substituição ao original, para a realização dos próximos experimentos como o ZnPc-Lipossomos.

Assim, desta forma foi possível realizar uma avaliação dos efeitos da TFD após o emprego de diferentes concentrações do ZnPc-lipossomo previamente incubado com a bactéria ou com os fibroblastos.

\subsubsection{Efeito da TFD sobre $S$. mutans e fibroblastos utilizando-se o Zinco ftalocianina}

Avaliadas as características fotofísicas e fotoquímicas do ZnPc-lipossomo, 


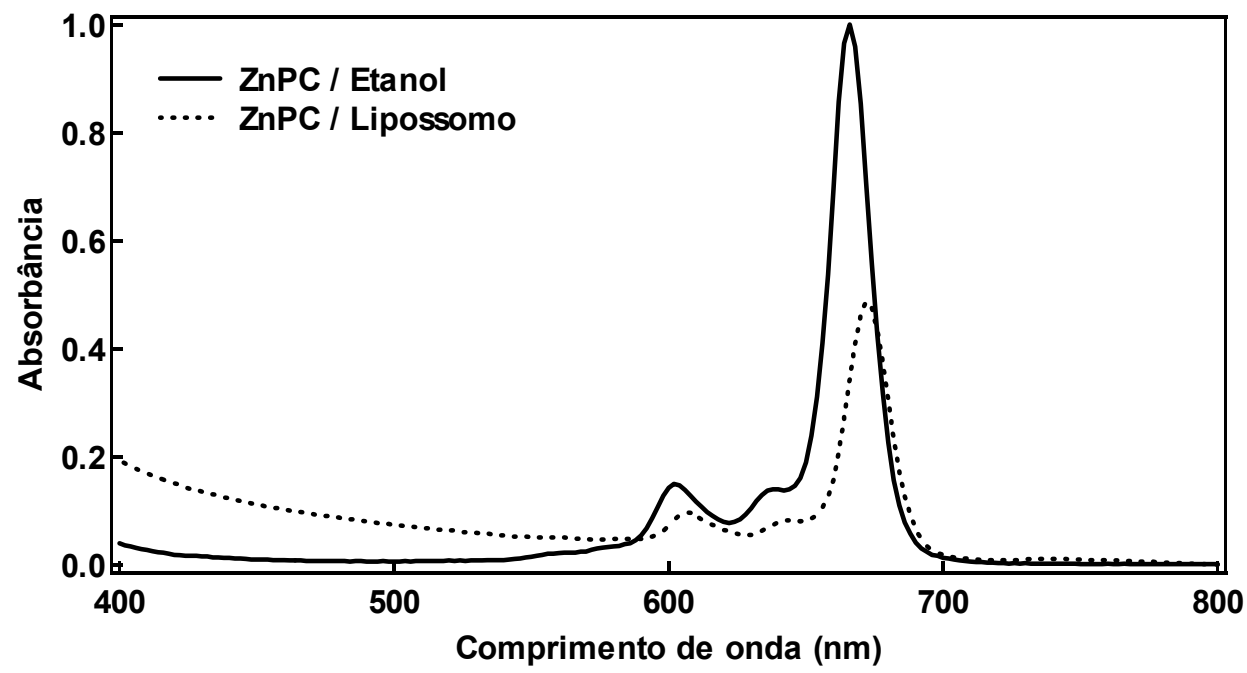

Figura 22: Espectros de absorção normalizados do corante ZnPC em meio etanólico e lipossomal. Faixa de varredura empregada: 400 a $800 \mathrm{~nm}$. 


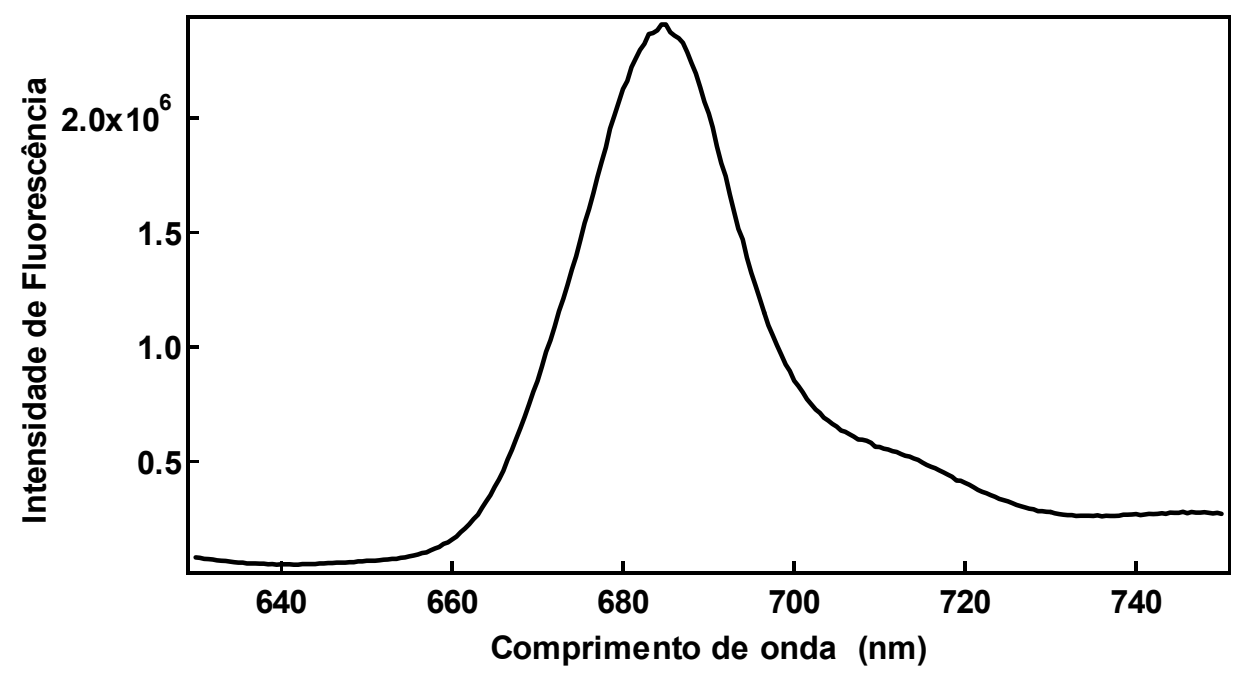

Figura 23: Espectro de emissão de fluorescência de ZnPC em meio lipossomal $(3,78$ $\mu \mathrm{mol} / \mathrm{L})$. Excitação fixa em $610 \mathrm{~nm}$, com faixa de varredura de 630 a $750 \mathrm{~nm}$, conforme descrito em Material e Métodos. 


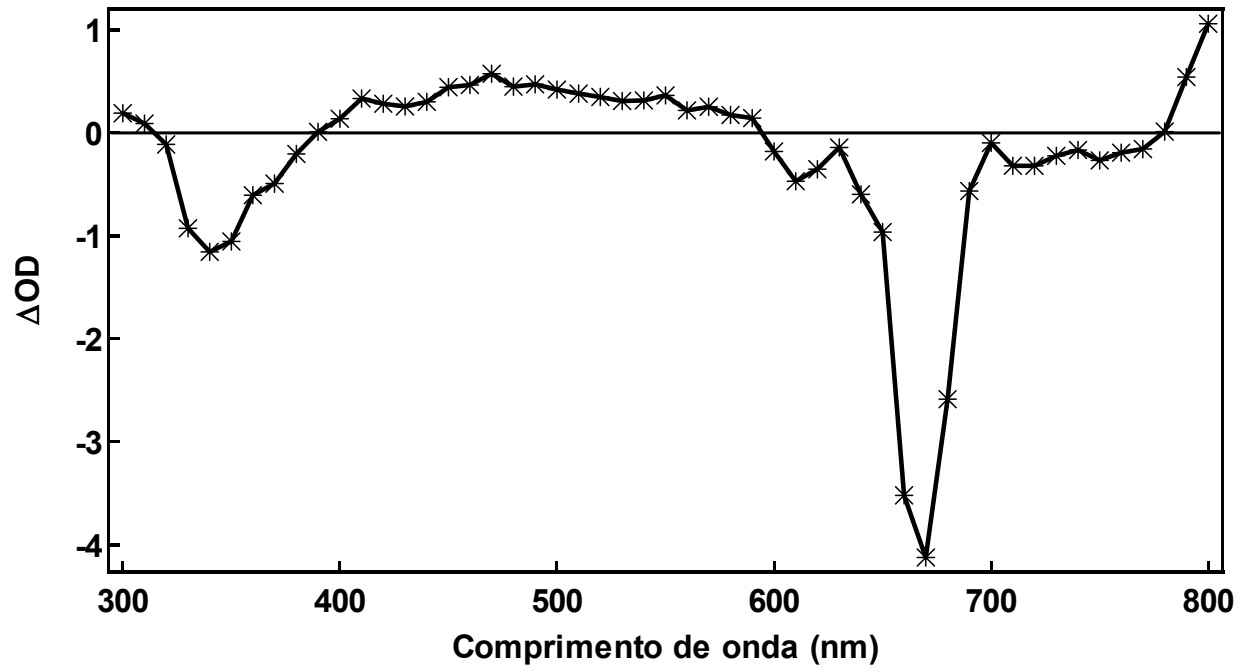

Figura 24: Espectro de absorção do transiente do corante ZnPC incorporado em lipossomos $(3,78 \mu \mathrm{mol} / \mathrm{L}), 0,21 \mu$ s após a excitação por pulso de laser em $355 \mathrm{~nm}$, com faixa de varredura de 300 a $800 \mathrm{~nm}$, mostrando a absorção máxima do triplete e o fotobranqueamento do estado fundamental. 


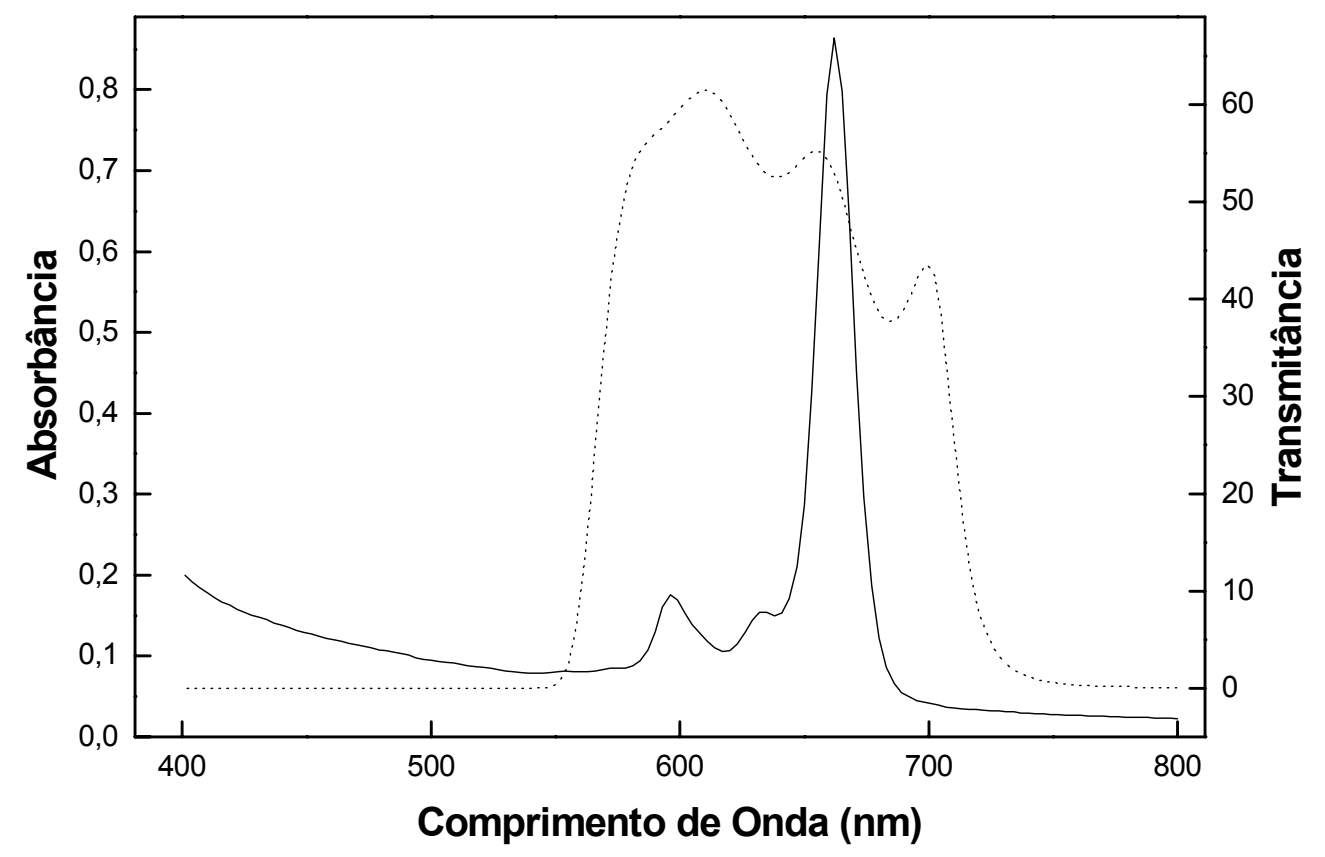

Figura 25: (__ Espectro de absorção da ZnPc-Lipossomo 3,78 $\mu \mathrm{mol} / \mathrm{L}$ em tampão salino pH 7.4 (PBS) e (-----) espectro de transmitância do filtro de luz (600 - $700 \mathrm{~nm})$ adaptado ao fotopolimerizador de resina odontológica. 
assim como da luz empregada para sua fotoativação (fotopolimerizador com filtro adaptado), um estudo da capacidade da TFD em inativar o Strepcotoccus mutans foi realizado.

Como citado anteriormente, para realização da fotoirradiação com o fotopolimerizador, foi necessário efetuar a troca do filtro do equipamento. Assim, o filtro original (400 a $500 \mathrm{~nm}$ ) foi substituído pelo filtro adaptado (com faixa de emissão de 600 a $700 \mathrm{~nm}$ ) possibilitando a fotoativação do ZnPc-lipossomo. Desta forma, após a irradiação com o a bactéria foi plaqueada, conforme descrito em Material e Métodos e sua taxa de inativação calculada.

Assim, a Figura 26 mostra os resultados obtidos após a contagem das células viáveis (S. mutans e fibroblastos) que foram submetidas à TFD. Especificamente, foi avaliado o efeito do aumento da concentração do corante incubado com as células antes da irradiação sobre a viabilidade celular. Para isto as concentrações foram variadas de 0 a $8,14 \mu \mathrm{mol} / \mathrm{L}$ de ZnPc-lipossomo. Numa concentração de 0,79 $\mu \mathrm{mol} / \mathrm{L}$ foi observada a inativação bacteriana de $25 \%$ das células (aplicando-se uma dose de luz de $325,1 \mathrm{~mJ} / \mathrm{cm}^{2}$ ) que alcançou $100 \%$ de inativação quando préincubado com 3,78 $\mu \mathrm{mol} / \mathrm{L}$ do corante. A toxicidade "per se", apresentou-se com valores máximos em torno de $20 \%$ quando do uso de $50 \mu \mathrm{mol} / \mathrm{L}$, indicando também que a morte bacteriana é certamente conseqüência das espécies reativas de oxigênio produzidos, devido à diferença na concentração de droga necessária para fotoinativar as bactérias na ausência ou presença de luz.

Para os fibroblastos a morte celular avaliada a partir dos experimentos com MTT ou Azul Tripan (descritos em Material e Métodos), após a terapia fotodinâmica, apresentaram uma toxicidade de aproximadamente $80 \%$ para concentrações acima de $3,78 \mu \mathrm{mol} / \mathrm{L}$, com uma toxicidade no escuro máxima de $20 \%(50 \mu \mathrm{mol} / \mathrm{L}$ de ZnPc-Lipossomo), sugerindo que o emprego da TFD in vivo, nestas condições, está comprometido devido a alta toxicidade do sistema ZnPc-Lipossomo apresentada sobre as células bucais (inserto da Figura 26).

As ftalocianinas têm sido empregadas como compostos fotossensíveis na TFD visando a destruição de células cancerígenas, de bactérias e vírus (STERNBERG \& DOLPHIN, 1993). A principal característica fotofísica destes corantes consiste numa forte absorção na região do vermelho do espectro de UVvisível (banda Q) com uma sobreposição ("overlap") na região de máxima penetração de luz nos tecidos (JORI, 1996). Em contrapartida, para o emprego da 
TFD em S. mutans, a penetração em tecidos, baseado na chamada janela terapêutica não se faz necessária, visto que normalmente esta bactéria não é uma célula invasiva ou hospedeira de células humanas, mas sim de superfície.

De forma contrária, há uma considerável importância na permeação da luz pelo biofilme formado pela bactéria. Assim, fica evidente que a técnica descrita pode ser eficiente também contra bactérias tanto em meio planctônico quanto para em um biofilme.

O emprego de lipossomos na formulação de drogas para a TFD é baseada na observação de que a afinidade dos agentes fotossensíveis pelos tecidos neoplásicos aumenta conforme a hidrofobicidade destes agentes (RICHELLI et al., 1993). Apesar disso, no caso específico da TFD contra o S. mutans, é clara a dificuldade em se manter uma droga altamente insolúvel em meio aquoso (no caso o $\mathrm{ZnPc}$ ) na presença das bactérias, sendo necessário um carreador.

Mesmo assim, estudos que avaliem a afinidade descrita por Richelli e colaboradores (RICHELLI et al., 1993) devem ser realizados para a interação dos lipossomos com as bactérias tanto em meio líquido (planctônico) ou quando presentes na constituição de biofilmes.

\subsubsection{Avaliação da formação de biofilme após TFD}

A placa dental é o termo comumente empregado para o biofilme que é formado na superfície do dente e que consiste numa complexa comunidade microbiana presente na superfície dental. Além disso, a literatura já descreveu que são as substâncias orgânicas, provenientes da fermentação lática de alguns carboidratos, os responsáveis pela desmineralização da hidroxiapatida do dente (SOUKOS et al., 2000; PAULINO et al., 2005).

Assim, o estudo da TFD sobre a viabilidade de $S$. mutans em meio planctônico é somente um marco inicial dos estudos de TFD sobre este microrganismo, permitindo a padronização da técnica e um estudo inicial sobre os possíveis métodos de emprego da TFD contra o $S$. mutans.

Neste sentido, um estudo avaliando os efeitos da TFD em biofilme formado por S. mutans foi realizado e, diferentemente do que já foi mostrado pela literatura (ZANIN et al., 2005), este estudo emprega uma luz de baixo custo (foto- 


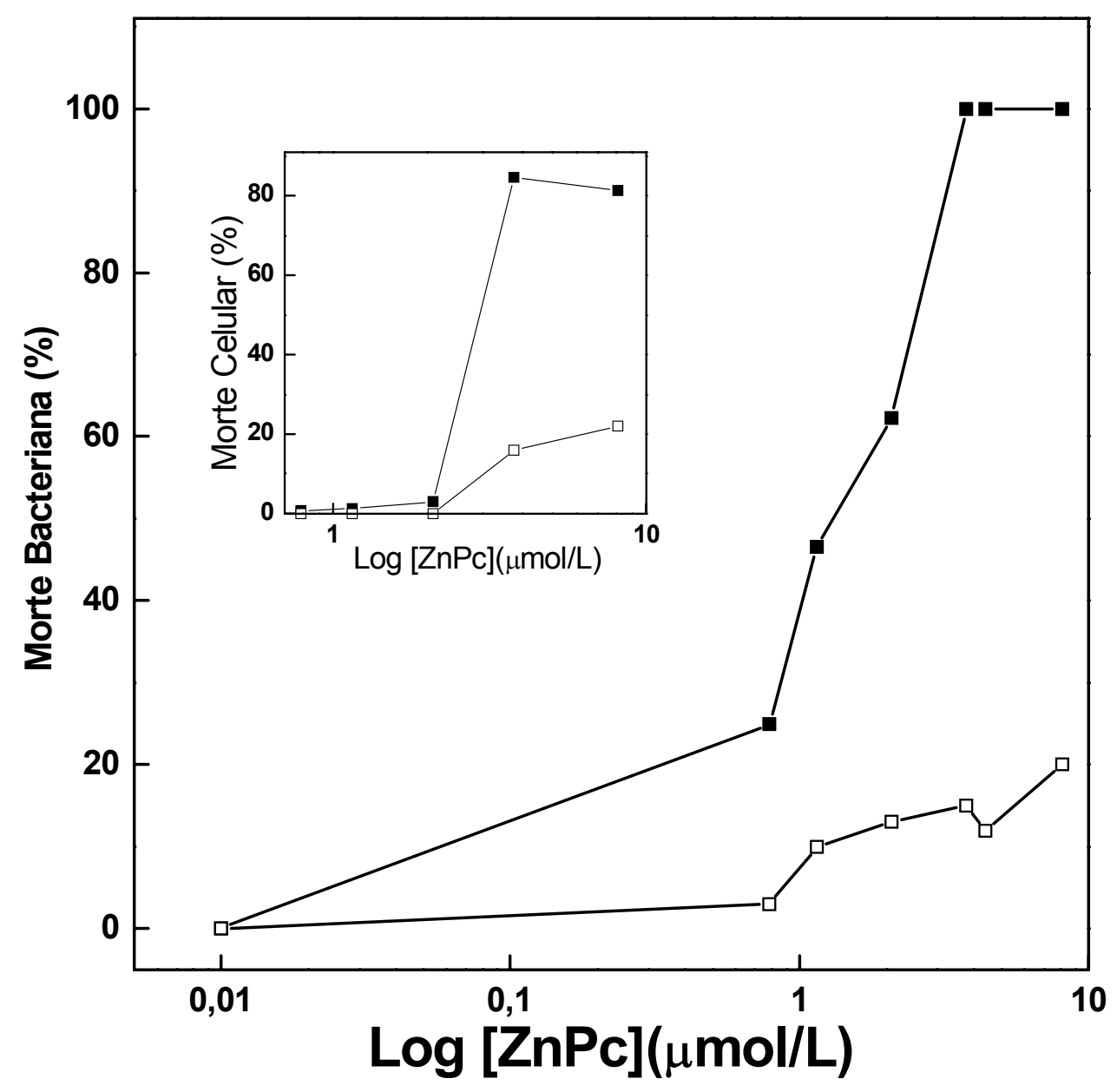

Figura 26. Viabilidade de $S$. mutans na presença de variáveis concentrações de ZnPcLipossomo. A bactéria ( $10^{3}$ UFC) foi incubada com ZnPc-Lipossomo durante 10 minutos e incubada em meio de cultivo TSA durante 36 horas a $37^{\circ} \mathrm{C}$ na ausência de luz com $(\bullet)$ ou sem (०) irradiação de luz pelo fotopolimerizador. Inserção: viabilidade dos fibroblastos na presença de variáveis concentrações de ZnPc-Lipossomo. As células $\left(10^{6}\right)$ foram incubadas com o corante durante 10 minutos e crescidas em DEMEN/F-12 por 24 horas no escuro com (घ) ou sem ( $\square$ ) irradiação com o fotopolimerizador. 
polimerizador de resina odontológica) ao invés de lasers.

Ao mesmo tempo, a proposta do trabalho está também focada no emprego futuro deste equipamento, no tratamento de algumas doenças que envolvem microrganismos presentes no trato bucal (PAULINO et al., 2004b)

A Figura 27 mostra as imagens do biofilme formado por S. mutans antes e após o emprego da TFD utilizando-se Rose bengal, Protoporfirina IX e a ZnPclipossomo, processadas conforme descrito em Material e Métodos (3.9.2).

A dose de luz e a concentração dos agentes fotossensíveis foram as mesmas empregadas nos experimentos de TFD em meio planctônico. Os resultados indicam que há uma diminuição do biofilme formado quando o mesmo é submetido à terapia.

$\mathrm{Na}$ verdade, as microscopias demonstram um significante decaimento da formação do biofilme que, apesar de não ter sido quantitativamente comparado ao grupo Controle, pode-se afirmar que os biofilmes submetidos a terapia fotodinâmica utilizando-se $325,1 \mathrm{~mJ} / \mathrm{cm}^{2}$ de densidade de energia, apresentam uma menor taxa de crescimento, quando comparado ao controle.

Este resultado também vem a reforçar a hipótese de que a diminuição da formação do biofilme, assim como a inativação celular observada nos experimentos anteriores, são fruto da formação de espécies reativas de oxigênio que, possivelmente tenham afetado a viabilidade bacteriana.

Na Figura 27 pode ser observado que há uma confluência bacteriana sobre o poço onde ocorre o crescimento bacteriano, diferentemente, nos poços onde foram realizados os experimentos com a TFD, uma menor confluência é observada, apresentando-se com uma intensidade intermediária ao grupo Controle e ao poço limpo.

Estes estudos iniciais com a TFD aplicada ao biofilme podem ser empregados no estudo do crescimento deste biofilme em outros materiais como suportes de hidroxiapatita, dentes ou ainda sobre materiais de restauração.

\subsubsection{Localização dos agentes fotossensíveis em S. mutans}

Estudos realizados por Merchat e colaboradores, demonstram que a localização celular de porfirinas meso-substituídas em bactérias Gram negativas é gradativamente menor de acordo com o número de lavagens em tampão salino aos quais as células são submetidas. Além disso, o tempo de incubação das células 


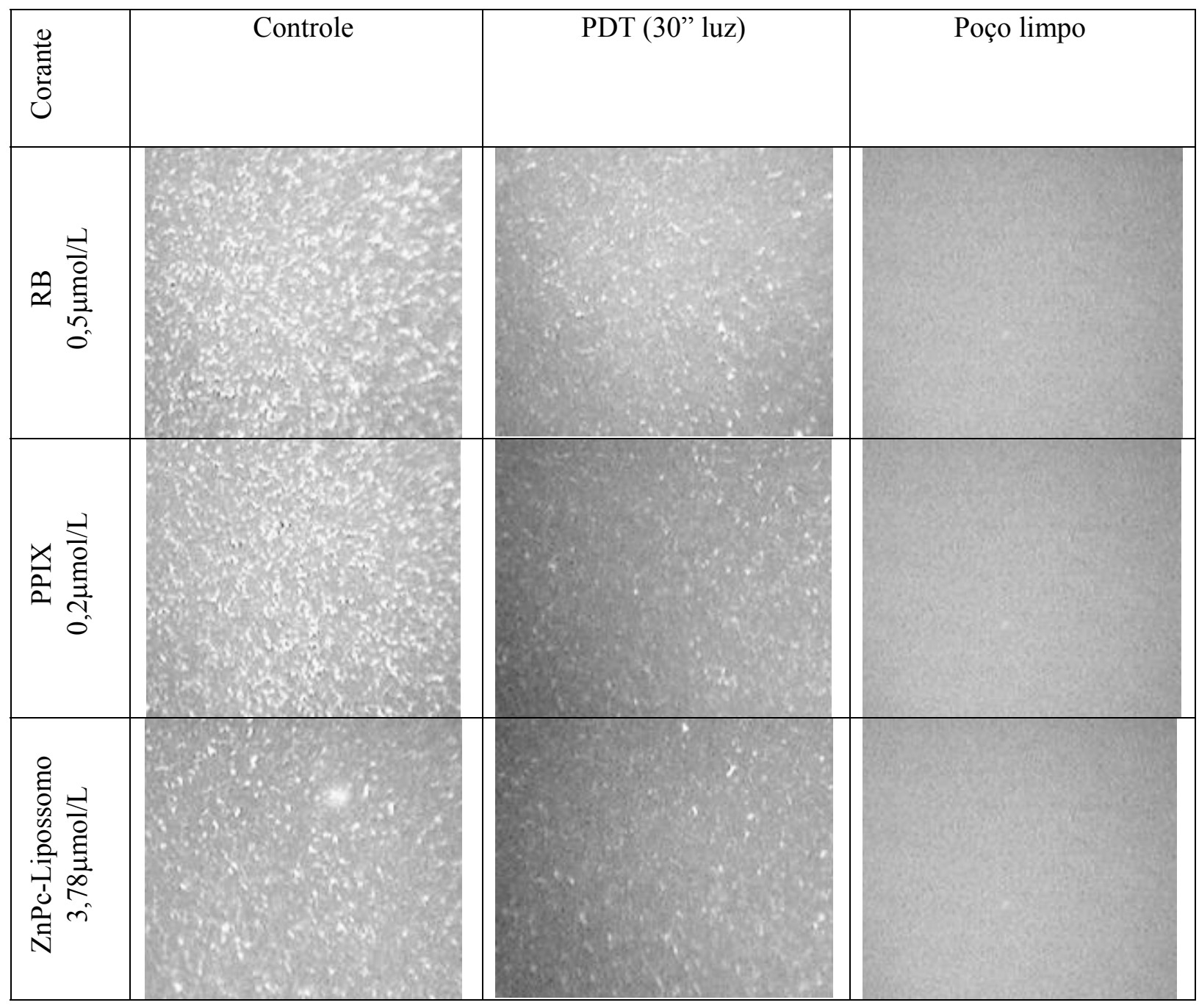

Figura 27: Fotomicrografia do biofilme formado por S. mutans após crescimento durante 2 horas em meio completo suplementado com $1 \%$ de sacarose $(\mathrm{p} / \mathrm{v})$ : RB, PPIX e ZnPc são respectivamente as células tratadas com os agentes fotossensíveis Rose bengal, Protoporfirina IX e ZnPc-lipossomo. O controle refere-se ao biofilme formado e não tratado com a TFD. O poço limpo refere-se à micrografia do poço sem nenhum biofilme crescido (aumento de $100 \mathrm{X}$ ). 
com o corante implica diretamente na concentração do mesmo em diferentes compartimentos celulares (MERCHAT et al., 1996).

Assim, possivelmente, uma maior concentração do corante dentro das células estará diretamente implicado com um maior tempo de incubação das mesmas com a maioria dos agentes fotossensíveis.

Além disso, sabe-se que as espécies reativas produzidas pelos agentes fotossensíveis são de vida curta e que não conseguem migrar pelos diferentes compartimentos celulares devido a sua alta reatividade.

Neste sentido, uma melhor compreensão do local (região celular) onde o agente fotossensível se localiza pode auxiliar numa melhor compreensão dos mecanismos de ação da TFD sobre a bactéria, ou seja, determinando-se a localização do corante, pode ser determinada uma possível ação do mesmo nas respectivas regiões celulares como citoplasma, membrana, parede, algumas organelas, etc.

Um experimento realizado neste sentido foi com irradiações feitas com o fotopolimerizador, realizadas imediatamente após a adição dos agentes fotossensíveis (Rose bengal, Protoporfirina e $\mathrm{ZnPc}$-lipossomo) às diferentes suspensões bacterianas. Assim, evitou-se uma possível entrada dos corantes nas células, possibilitando que assim, o corante ligado à parede celular ou à membrana fossem os responsáveis pela produção de ERO's que levassem à inativação bacteriana.

Desta forma, os resultados obtidos nestes experimentos foram respectivamente semelhantes aos apresentados anteriormente (para todos os agentes fotossensíveis pré-incubados por 10 minutos), sugerindo que o corante não precisa entrar na célula para causar sua inativação. Além disso, bactérias que não foram irradiadas não foram afetadas pelo corante mesmo com pré-incubação (toxicidade "per se").

Estes resultados somente sugerem a não entrada do corante na célula (citoplasma celular), apesar do que para sua confirmação é importante uma avaliação da presença dos agentes fotossensíveis no citoplasma bacteriano.

Possivelmente, os efeitos observados (inativação bacteriana) são provenientes de danos causado à(s) biomolécula(s) presentes nesta bactéria (proteína, lipídeo ou ácidos nucléicos), especificamente em sua parede ou membrana. 
Assim, devido à possibilidade das espécies reativas estarem promovendo danos à membrana bacteriana, estudos avaliando a peroxidação lipídica ou de alteração da atividade de enzimas presentes nesta membrana seriam importantes para esta compreensão.

\subsubsection{Avaliação da capacidade acidogenica de $S$. mutans após TFD com os diferentes agentes fotossensíveis}

Um experimento avaliando a variação do pH de uma suspensão celular em função do tempo é mostrado na Figura 28. Para isto, o Rose bengal, a PPIX e o ZnPc-lipossomo foram adicionados à suspensão bacteriana para uma posterior irradiação com o fotopolimerizador $\left(325,1 \mathrm{~mJ} / \mathrm{cm}^{2}\right)$. Após esta irradiação, as células em suspensão foram avaliadas durante 10 minutos quanto a sua capacidade de produção de ácidos (avaliação do metabolismo de glicose).

Os resultados obtidos mostram que para as células que não foram submetidas à terapia (células controle), um decaimento significativo do $\mathrm{pH}$ é observado ( $\Delta \mathrm{pH} \cong 0,55)$, o que revela um metabolismo rápido da glicose como fonte de carbono para a o processo fermentativo. Por outro lado, o emprego da TFD utilizando o Rose bengal $(0,5 \mu \mathrm{mol} / \mathrm{L})$ e a Protoporfirina IX $(0,2 \mu \mathrm{mol} / \mathrm{L})$ fez com que as bactérias diminuíssem significativamente sua capacidade acidogênica $(\Delta \mathrm{pH} \cong$ 0,01 e 0,05 respectivamente), sugerindo que houve uma redução do processo metabólico responsável pela produção ou extrusão destes ácidos para o meio extracelular. Esta diminuição da capacidade acidogênica pode ser reflexo de vários fatores, que afetam a atividade ATPase (H+ATPase, ou outras enzimas extrusoras de prótons), inbição de enzima(s) da via glicolítica, entre outros que porventura estejam direta ou indiretamente implicados no metabolismo dos carboidratos.

Já a TFD utilizando o ZnPc-Lipossomo não afetou significativamente a capacidade acidogênica da bactéria $(\Delta \mathrm{pH} \cong 0,4)$ pois, este valor não expressa uma significativa diminuição da capacidade acidogênica quando comparado ao controle $(\Delta \mathrm{pH} \cong 0,55)$. Assim, da mesma forma que os demais corantes, o ZnPc-lipossomo também foi capaz de inativar as bactérias em meio planctônico e, mas não foi capaz de promover uma diminuição da acidogenia da bactéria. Uma possível explicação para este fato é que o sistema lipossomal possa interferir na inativação bacteriana 
de forma diferente dos demais corantes.

Além disso, quando avaliado a toxicidade "per se" de todos os corantes ou somente da luz, resultados semelhantes aos encontrados quando aplicada a TFD em meio planctônico também foram encontrados, indicando que a diminuição da capacidade acidogênica de $S$. mutans é devido às espécies reativas de oxigênio formadas.

Um experimento específico, avaliando a atividade ATPase total de uma fração membrana de $S$. mutans foi de grande importância nesta etapa do trabalho, haja visto a possibilidade das espécies reativas formadas estarem alterando especificamente a atividade ATPase de algumas enzimas que realizam a extrusão de prótons.

\subsubsection{Avaliação da atividade ATPase total de fração de membrana de $S$. mutans após emprego da TFD}

Conforme descrito por Magalhães e colaboradores (MAGALHÃES et al., 2003), a capacidade extrusora de prótons está ligada à atividade de enzimas (ATPase do tipo P e F) presentes na membrana do S. mutans. Assim, os resultados dos experimentos empregados para na avaliação da capacidade acidogênica (item 4.2.6) sugerem a possibilidade de existir uma relação entre as espécies reativas de oxigênio com a diminuição desta capacidade.

Neste sentido uma fração de membrana de $S$. mutans obtida conforme descrito em Material e Métodos, foi submetida ao tratamento com os agentes fotossensíveis (Rose bengal, Protoporfirina e $\mathrm{ZnPc}$-lipossomo) para a avaliação da atividade ATPase total.

Para isto foram empregados 0,05; 0,02 e 0,37 $\mu \mathrm{mol} / \mathrm{L}$ de Rose bengal, PPIX e ZnPc-lipossomos respectivamente, para tratar as frações de membrana a serem submetidas a TFD. A luz empregada foi a mesma utilizada nos experimentos anteriores $\left(325,1 \mathrm{~mJ} / \mathrm{cm}^{2}\right)$. Surpreendentemente, nenhum corante empregado, após aplicação de luz, foi capaz de promover significativas alterações da atividade ATPase.

A literatura descreve a ação da TFD em sistemas enzimáticos, causando uma diminuição da atividade específica para algumas enzimas (PRINSZE et al., 1991). Estes resultados indicam que as espécies reativas de oxigênio formadas não 
foram suficientes ou não alcançaram os sítios ativos das ATPases de forma a modular suas atividades.

Neste sentido, mais estudos envolvendo uma variação tanto da concentração dos corantes empregados quanto a dose de luz utilizada serão necessários para uma maior avaliação da relação entre a TFD e a atividade ATPase total das frações de membrana.

\subsubsection{Avaliação do perfil eletroforético de proteínas do lisado bacteriano}

A seleção natural de organismos no meio onde vivem não se dá somente pelas suas características genotipicas. Uma nova modificação que permita a proliferação de um organismo ocorre através da expressão de uma resposta adaptativa à diversas condições de estresse fisiológico do ambiente. Assim, estudos de mudanças de temperatura de crescimento, levaram ao descobrimento de proteínas de choque térmico (HSP), ou também chamadas de proteínas de estresse (HRIMECH et al., 2000).

As proteínas de estresse são divididas em famílias e, as mais conhecidas são as HSP-60 (GroEL, aproximadamente de 60 KDa.) e HSP-70 (GroEL, aproximadamente de $70 \mathrm{KDa}$ ) (HRIMECH, et al., 2000), que podem ser analisadas após a indução do estresse (térmico, osmótico ou ácido) nas bactérias, seguido por uma análise eletroforética acompanhada ou não por uma análise de "blotting".

$\mathrm{Na}$ Figura 29, um gel de poliacrilamida (SDS-PAGE) foi empregado na separação eletroforética de um lisado celular obtido conforme descrito em Material e Métodos. Na linha PM estão dispostos os padrões de peso molecular (45 - 205 $\mathrm{KDa}$ ). As linhas 1 e 2 mostram respectivamente o perfil eletroforético de células submetidas ao controle osmótico (cloreto de sódio $0,5 \mathrm{~mol} / \mathrm{L}$ ) e as células não submetidas ao estresse (grupo controle). A marcação (retângulo) no gel refere-se a região onde podem ser encontradas as proteínas de choque térmico expressas (com peso molecular de $70 \mathrm{KDa}$ ).

Estas bandas protéicas, referentes às HSP, não foram observadas nestas condições, o que indica a necessidade de uma melhor padronização do cultivo e tratamento das células para a realização deste experimento.

Utilizando técnicas de proteômica, McNeill e Hamilton conseguiram evidenciar perfeitamente uma diferença na expressão das proteínas HSP-60 e HSP- 


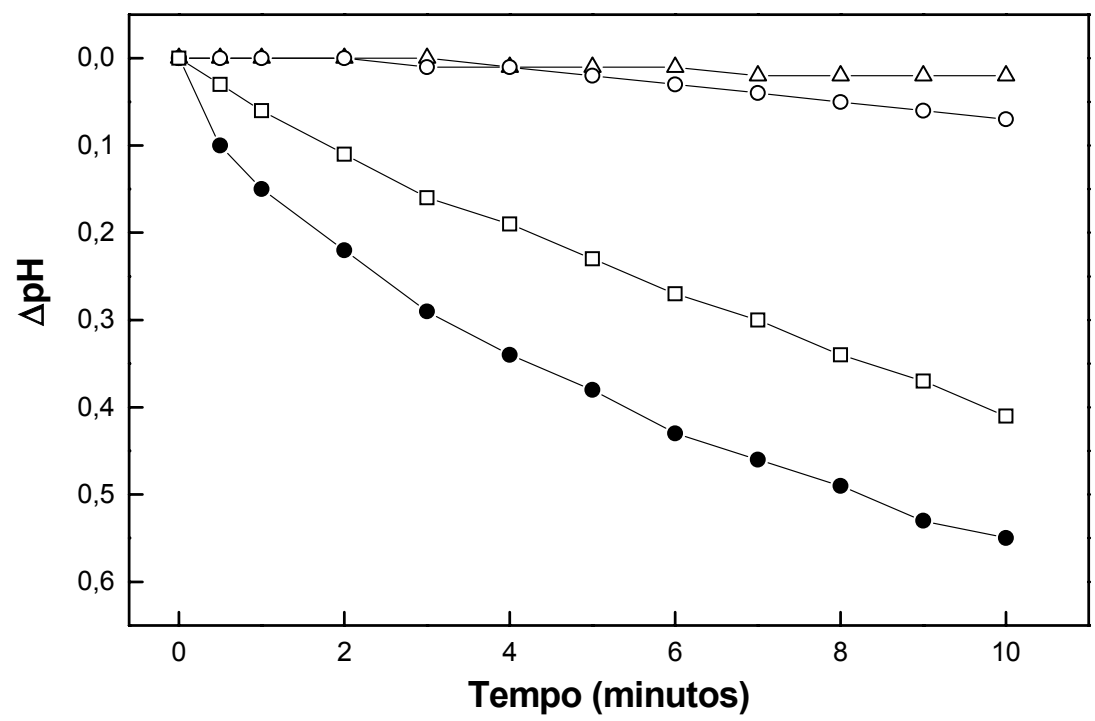

Figura 28: Variação do $\mathrm{pH}$ observado em suspensão de $S$. mutans na presença de glicose (50 mmol/L) após terapia fotodinâmica: (•) Grupo Controle, $(\Delta)$ Rose bengal, (०) Protoporfirina IX e ( $\square$ ) ZnPc-lipossomo. Durante 10 minutos foi avaliado o $\mathrm{pH}$ da suspensão. Valores expressos em $\Delta \mathrm{pH}$ conforme descrito em Materiais e Métodos. 
70 após uma indução de estresse ácido (McNEIL \& HAMILTON,2004), diferentemente, a sensibilidade da técnica empregada neste experimento não permitiu a visualização de bandas protéicas relacionadas às HSP.

\subsubsection{Avaliação da expressão de proteínas de choque térmico em $S$. mutans após TFD com Rose bengal}

Conforme descrito por Len e colaboradores, há uma maior expressão de proteínas de estresse após sua indução (estresse ácido) em Streptococcus mutans . Inclusive, uma recente análise proteômica reforça a idéia de que ocorrem também alterações nas vias metabólicas deste organismo quando este é exposto a condições estressantes (LEN et al., 2004).

Assim, proteínas de choque térmico podem indicar em microrganismos a existência de alguma condição estressante que possa comprometer a viabilidade celular. Neste sentido, um experimento para avaliar a expressão destas proteínas em S. mutans foi realizado.

A bactéria $S$. mutans foi submetida a diversas condições de estresse, posteriormente lisada. Este lisado celular foi submetido a uma eletroforese desnaturante (SDS-PAGE), e posteriormente transferido para uma membrana de nitrocelulose que foi tratada com anticorpos específicos para proteínas de estresse (HSP-70) conforme descrito em Material e Métodos.

Assim, nossos resultados indicam que $S$. mutans expressa esta classe de proteína em todas as situações de estresse induzidas (inclusive no grupo controle). A Figura 30 mostra um blotting das proteínas, em papel de nitrocelulose. Estas proteínas podem ser confirmadas nas 5 colunas da membrana com uma intensidades de cor que indicam semelhantes expressões protéicas para a HSP70. Neste sentido, as condições avaliadas não foram suficientes para induzir nenhuma diferença na expressão destas proteínas pela bactéria.

Diferentemente, Hrimech e colaboradores encontraram diferentes expressões destas proteínas após uso de xilitol ou empregando-se mutantes de $S$. mutans que não expressam estas proteínas (HRIMECH et al., 2000).

\subsubsection{Avaliação do perfil eletroforético de DNA de $S$. mutans após emprego de TFD na presença de diferentes agentes fotossensíveis}


Uma das conseqüências da acidificação intracelular é a perda de bases púricas e/ou pirimidicas do DNA. Assim, danos a esta molécula, não reparados, bloqueiam sua síntese ou replicação, podendo ser letal a célula (LEN et al., 2004).

Após TFD, a possível perda da atividade ATPase poderá induzir a uma diminuição do $\mathrm{pH}$ citoplasmático bacteriano, causando portanto, como já descrito anteriormente, danos ao DNA.

A Figura 31 mostra o efeito da fotosensibilização no DNA de $S$. mutans inativado pela TFD. Nas linhas 1, 2, 3 e 4 estão indicadas as amostras de DNA obtidas da extração após o emprego da terapia com Rose bengal, PPIX, ZnPclipossomo e também o Grupo Controle, respectivamente. O DNA analisado não apresentou danos, mostrando-se sem nenhuma fragmentação.

Por outro lado, Bhatti e colaboradores mostram uma degradação do DNA após o emprego da TFD na bactéria Porphyromonas gingivalis, sugerindo que a morte celular pode ser proveniente do dano ao material genético deste organismo (BHATTI et al., 1998).

O emprego da TFD sobre um microrganismo Gram positivo tem como conseqüência a inativação bacteriana, causando efeitos específicos sobre algumas organelas e estruturas celulares, conforme mostrado para S. mutans no presente trabalho. Entretanto, os efeitos causados pela TFD em microrganismos Gram negativos, como a $P$. gingivalis, mostraram-se diferentes, sugerindo que os efeitos deletérios sobre o $S$. mutans possam estar ocorrendo em microambientes diferentes ou provenientes de efeitos menos drásticos no próprio DNA, como a formação de adutos que impeçam uma possível síntese ou transcrição. 


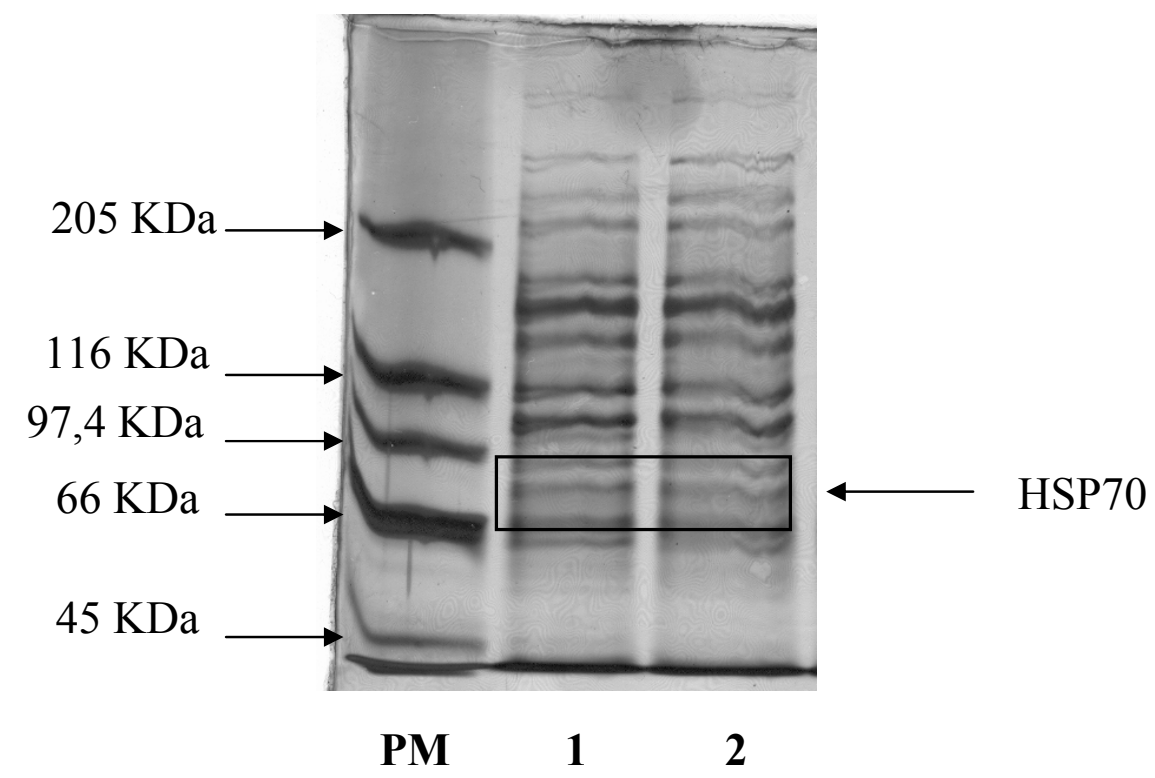

Figura 29. Eletroforese de gel de poliacrilamdia para o li8sado pretéico de S. mutans. A bactéria foi cultivada e posteriormente lisada com tampão de lise. As proteínas (50 $\mu \mathrm{g}$ por linha) separadas em SDS-PAGE 7,5\%, PM: peso molecular padrão; 1: S. mutans estressado com $\mathrm{NaCl}$; 2: $S$. mutans não estressado (controle negativo). Tratamentos conforme descrito em Material e Métodos. 


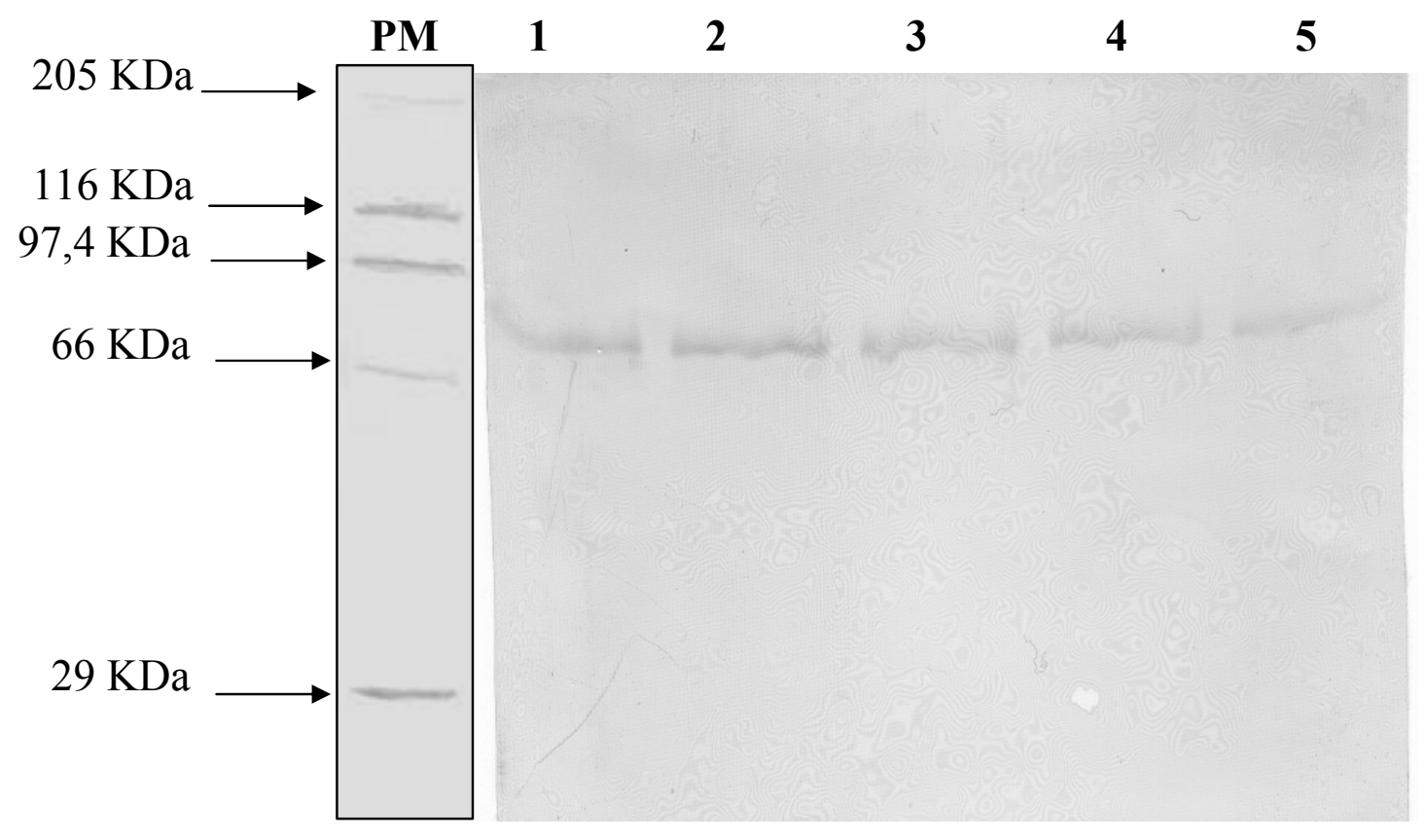

Figura 30. Imunoblot de proteínas (Heat Shock Protein 70). S. mutans foi cultivado e posteriormente lisados com tampão de lise. As proteínas $(50 \mu \mathrm{g}$ por linha) separadas em SDS-PAGE $10 \%$, foram transferidas para uma membrana de nitrocelulose, à qual foi incubada com anticorpo anti-GROEL (1:100) e anticorpo monovalente conjugado com peroxidase. 1: S. mutans submetido a TFD; 2: S. mutans irradiado com Luz proveniente do fotopolimerizador de resina odontológica; 3: S. mutans estressado com $\mathrm{NaCl}$ 4: $S$. mutans não estressado (controle negativo); 5: $S$. mutans tratado com Rose bengal. Tratamentos conforme descrito em Material e Métodos. 


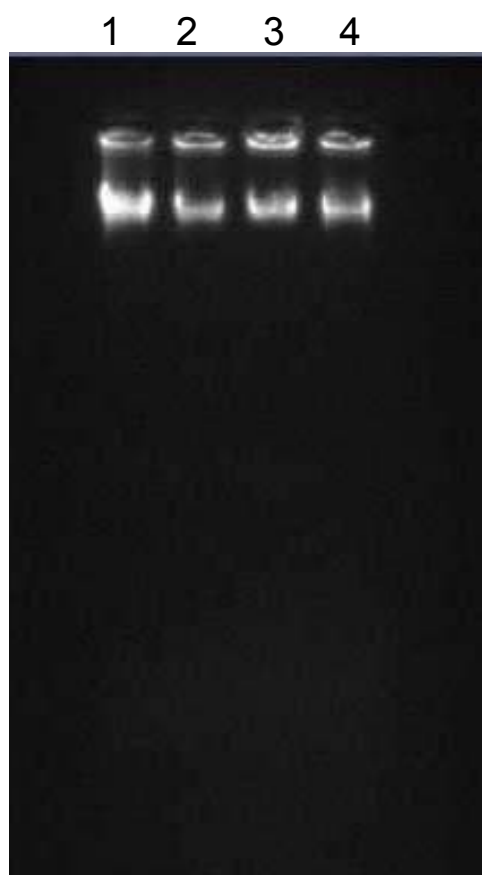

Figura 31: Gel de agarose das amostras de DNA obtidas de S. mutans. 1: S. mutans não submetido a TFD; 2: $S$. mutans submetido a TFD com Rose bengal; 3: $S$. mutans submetido a TFD com PPIX e 4: S. mutans submetido a TFD com ZnPc-lipossomos. 


\section{CONCLUSÃO}

Conforme o proposto, a metodologia padronizada em nosso trabalho possibilitou o cultivo de $S$. mutans em meio líquido (planctônico) ou na forma de biofilme, tornando-se possível assim a realização de testes com a aplicação da terapia fotodinâmica. As curvas de crescimento da bactéria na presença de diferentes fontes de carbono (xilose e/ou glicose) ou diferentes meios de cultivo (TSB ou meio completo) permitem avaliar as características de seu crescimento e consumo de glicose.

Em meio líquido, pode-se concluir que, entre a $5^{\mathrm{a}}$ e $10^{\mathrm{a}}$ hora após o inóculo (fase "Log"), há uma maior atividade metabólica da bactéria, reflexo de um aumento significativo da densidade óptica do meio de cultivo, com um respectivo aumento da taxa de crescimento bacteriano. Assim, as células obtidas para a realização deste trabalho foram crescidas até a fase "Log", garantindo-se um número maior de células metabolicamente ativas e viáveis para o experimento.

Uma análise das curvas de crescimento possibilitou avaliar o metabolismo anaeróbico de S. mutans que consome açúcares fermentáveis (glicose, frutose, sacarose e maltose), mostrando-se hábil na produção de ácidos.

De acordo com os objetivos do trabalho, uma fonte de luz já disponivel em consultórios odontológicos foi selecionada para o emprego na TFD. Desta maneira, o fotopolimerizador de resina odontológica foi o equipamento escolhido por apresentar baixo custo, fácil manuseio, além de não apresentar emissão de luz UVA ou UV-B que possa causar danos ao olho do operador e/ou do paciente no caso de uma aplicação clínica. Quando utilizado, o equipamento emite nas condições padronizadas, uma dose de luz de $325,1 \mathrm{~mJ} / \mathrm{cm}^{2}$ que corresponde a uma exposição à luz durante 30 segundos.

Os corantes selecionados para este trabalho foram o Rose bengal, a PPIX e a Zinco ftalocianina. O Rose bengal, um clássico agente fotossensível, possui significativo rendimento quântico na produção de oxigênio singlete $\left(\Phi_{\Delta}=0,90\right)$ e é empregado como uma droga modelo em muitos experimentos, apesar de não ser permitido o seu uso clínico na TFD. Quanto aos demais corantes empregados, estes foram caracterizados fotoquimicamente e os resultados permitiram concluir que há também uma produção de oxigênio singlete $\left(\Phi_{\Delta}\right)$ pela PPIX e ZnPclipossomo de 8,42 e 0,54, respectivamente. 
A diferença entre as concentrações de corante que causa a morte da bactéria na presença e na ausência de luz, indica que os compostos produzidos pela fotoativação são os responsáveis pela morte celular. Além disso, nas condições de terapia fotodinâmica estudadas, as concentrações de Rose bengal $(0,5 \mu \mathrm{mol} / \mathrm{L}) \mathrm{e}$ $\operatorname{PPIX}(0,2 \mu \mathrm{mol} / \mathrm{L})$ foram eficientes na inativação bacteriana ao passo que nestas mesmas condições, com os fibroblastos, não houve morte celular.

Diferentemente, para o ZnPc-lipossomo, a concentração encontrada de corante $(3,78 \mu \mathrm{mol} / \mathrm{L})$ necessária para fotoinativar a bactéria, resultou em uma toxicidade de aproximadamente $80 \%$ para os fibroblastos.

Além disso, células irradiadas imediatamente após a adição dos corantes foram semelhantemente inativadas após TFD, podendo ser desconsiderada uma incubação prévia com os agentes fotossensíveis e sugerindo uma possível ação das ERO's fora da bactéria.

Quanto à formação do biofilme, pode-se concluir que S. mutans foi capaz de formá-lo quando crescida na presença dos carboidratos analisados (glicose, frutose, sacarose, xilose ou maltose; $1 \% \mathrm{p} / \mathrm{v})$. Há uma maior formação deste biofilme quando as células foram crescidas na presença de sacarose. Além disso, o biofilme que foi submetido a um cultivo na presença de flúor, foi significativamente afetado pelo gradativo aumento deste haleto (1 a $5 \mathrm{mmol} / \mathrm{L}$ ). Esta diminuição na formação do biofilme pode ser justificada possivelmente pelo bloqueio da atividade glicolítica e/ou diminuição do substrato de adesão.

O biofilme de $S$. mutans também foi submetido a TFD com as doses de corantes empregadas e definidas em meio planctônico. Neste sentido, pode-se concluir que as concentrações dos corantes: Rose bengal (0,5 $\mu \mathrm{mol} / \mathrm{L})$, Protoporfirina IX (0,2 $\mu \mathrm{mol} / \mathrm{L})$ e ZnPc-lipossomo $(3,78 \mu \mathrm{mol} / \mathrm{L})$, foram também capazes de diminuir significativamente a intensidade do biofilme, observado após 4 horas de crescimento.

A TFD aparentemente não apresentou interferência na atividade ATPase total extraída da membrana da bactéria, com nenhum dos corantes estudados.

Em adição, os estudos para determinar a localização do corante na bactéria, da peroxidação lipídica, de análise do DNA, e de proteínas de estresse após TFD, não trouxeram nenhuma informação adicional conclusiva sobre o alvo específico das ERO's que causam a inativação bacteriana.

As técnicas descritas neste trabalho ainda não poderão ser utilizadas na 
clínica em substituição a técnicas existentes, mas, após maiores estudos, poderá ser empregada como uma modalidade complementar às quimioterapias antimicrobianas convencionais, por ser simples e de fácil emprego. O custo do fotopolimerizador também é um fator que deve ser ponderado pois na técnica proposta, é um equipamento barato e já disponível em consultório odontológico. Além disso, há a possibilidade de se utilizar diferentes corantes, sintéticos ou naturais, dada a capacidade de adaptação do equipamento a filtros de luz, tornando o processo ainda mais barato e simples de ser adequado às características do corante. 


\section{BIBLIOGRAFIA}

ACKROYD, R.; KELTY, C.; BROWN, N. and REED, M. The history of photodetection and photodynamic therapy. Photochem. Photobiol. 74(5): p.656-669, 2001.

ANWER, K., MEANEY, C., KAO, G., HUSSAIN, N., SHELVIN, R., EARLS, R.M., LEONARD, P., QUEZADA, A., ROLLAND, A.P. and SULLIVAN, S.M. Cationic lipidbased delivery system for systemic cancer gene therapy. Cancer Gene Ther. 7: p.1156-1164, 2000.

BENDER, G.R., SUTTON, S.V., MARQUIS, R.E. Acid tolerance, próton permeabilities, and membrane ATPases of oral streptococci. Infect. Immun. 53: p.331-338,1986.

BERKOWITZ, R.J., JORDAN, H.V., WHITE, G. The early establishment of Streptococcus mutans in the mouths of infants. Arch. Oral. Biol. 20: p.171-174,1975.

BERTOLONI, G.; SALVATO, B.; DALL'ACQUA, M.; VAZZOLER, M.; JORI, G. Hematoporphirin-sensitized photoinactivation of Streptococcus faecalis. J. Photochem. Photobiol. 39: 811-816,1984.

BHATTI, M.; MACROBERT, A.; MEGHJI, S.; HENDERSON W.M. A study of the uptake of toluidine blue $O$ by Porphyromonas gingivalis and the mechanism of lethal photosensitization. Photochem. Photobiol. 68(3): p.370-376,1998.

BOLIN, A.K.Children's dental health in Europe. An epidemiological investigation of 5and 12-year-old children from eight EU countries. Swedish Dent. J. Supplement 122, 1997.

BONNETT R, MCGARVEY, D.J., HARRIMAN A, LAND E.J, TRUSCOTT T.G, WINFIELD U.J. Photophysical properties of meso-tetraphenylporphyrin and some meso-tetra(hydroxyphenyl)porphyrins. Photochem. Photobiol. 48(3): p.271-6, Sep 1988.

BONNETT, R. Photosensitizers of porphirin and phtalocyanine series for photodynamic therapy. Chem. Soc. Rev. 19-33. 1988.

BOWYER, J.D.; HOLROYD, C.; CHANDNA, A. The use of the fluorescein disappearance test in the management of childhood epiphora. Orbit. 20(3): p.181187, 2001.

BOYAR, R.M.; THYLSTRUP, A.; HOLMEN, L.; BOWDEN, G.H.The microbiota associated with the development of initial enamel descalcification below orthodontic bands in vivo in children living in a fluoridated-water area. J. Dent. Res. 68: p. 17341738, 1989.

BRANCALEON, L; MAGENNIS, S.W.; SAMUEL, I.D.; NAMDAS, E.; LESAR, A.; MOSELEY, $\mathrm{H}$. Characterization of the photoproducts of protoporphyrin IX bound to human serum albumin and immunoglobulin G. Biophys. Chem. 109(3): p. 351-60, 2004.

BRANCALEON, L.; MOSELEY, H. Laser and non-laser light sources for 
photodynamic therapy. Lasers Med. Sci.. 17(3): p.173-186, 2002.

BRASSEUR, R.; DE LOOF, H.; RUYSSCHAERT. J.M.; ROSSENEU, M. Conformational analysis of lipid-associating proteins in a lipid environment. Biochim. Biophysic. Acta. 943(1): p. 95-102, 1988.

BRATTHAL, D. Demonstration of five serological groups of streptococcal strains resembling Streptococcus mutans. Odontol. Revy. 21: p. 143-152, 1997.

BURNS, T.; WILSON, M.; PEARSON, G.J. Efect of dentine and collagen on the lethal photosensitization of Streptococcus mutans. Caries Res.. 29: p. 192-197, 1995.

CAUGHMAN, G.B.; CAUGHMAN, W.F.; NAPIER, N.; SCHUSTER, G.S. Desinfection of visible-light-curing devices. Oper. Dent. 14(1): p.2-7,1989.

CHARLOTTE, E.R.; AKRAM, N.C.; HURRELL, F.; DRUCKER, D.B. Effects of nitrite and nitrate on the growth and acidogenicity of Streptococcus mutans. J. Dent.. 30: p.325-331, 2002.

CHARTTERJEE, S.; SRIVATAVA, T.S. Spectral investigation of the interactions of some porphirins with BSA. J. Porph. Phtal. 4: p. 147-157, 2000.

CHEN, P.S. Jr.; TORIBARA, T.Y.; WARNER, H. Micro-determination of phosphorus, Anal. Chem. 28: p.1756-1768,1956.

CIRINO, S.M.; SCANTLEBURY, S. Dental caries in developing countries. Preventive and restorative approaches to treatment. N. Y. State Dent. J. 64: 32-39, 1998.

CLARKE, JK. On the bacterial factor in the aetiology of dental caries. British J. Exp. Pathol; 5: p. 141-147,1924.

COHEN, L.B.; SALZBERG, B.M.; DAVILA, H.V.; ROSS, W.N.; LANDOWNE, D.; WAGGONER, A.S.; WANG, C.H. Changes in axon fluorescence during activity: molecular probes of membrane potential. J. Membr. Biol. 19(1): p. 1-36, 1974.

COOK, W.D. Curing efficiency and ocular hazards of dental photopolimerization sources. Biomaterials. 7(6): p. 449-454,1986.

COX, S.D.; LASSITER, M.O.; MILLER, B.S.; DOYLE, R.J. A new mechanism of action of fluoride on streptococci. Biochim. Biophysic. Acta. 1428: p. 415-423, 1999.

DAHL, T.A.; MIDDEN, W.R.; NECKERS, D.C. Comparison of photodynamic action by rose bengal in Gram-positive and Gram-negative bacteria. Photochem. Photobiol; 48: p. 607-612, 1988.

DEMAS, J.; CROSBY, G. Measurement of photoluminescence Quantum yields: A Review. J. Physical. Chem. 75: p.992-1024, 1971.

DASPHER, S.G.; REYNOLDS, E.C. pH regulation by Streptococcus mutans. J. Dent. Res. 71: p.1159-1165, 1991. 
DOUGHERTY, T.J.; GRINDEY, G.B.; FIEL, R.; WEISHAUPT, K.R.; BOYLE, D.G. Photoradiation therapy. II. Cure of animal tumors with hematoporphyrin and light.J. Natl. Cancer Inst. 55(1): p.115-21, Jul.1975.

DOUGHERTY, T.J.; GOMER, C.J.; HENDERSON, B.W.; JORI, G.; KESSEL, D. KORBELIK, M.; MOAN, J.; PENG, Q. Photodynamic therapy.. J. Natl. Cancer Inst. 90(12): p.889-905, 1998.

EICHWURZEL, I.; PEVZENER, H.; RODER, B. Photophysical studies of the pheophorbide a dimer. J. Photochem. Photobiol. 54: p.194-200, 2000.

ERICSON, M.B.; GRAPENGIESSER, S.; GUDMUNDSON, G. A spectroscopic study of the photobleaching of protoporphyrin IX in solution. Lasers Med. Sci. 18: p. 56-62, 2003.

FEJERSKOV, O.; EKSTRAND, J.; BURT, A. Fluoride in Dentistry, 2th edition, Munksgaard, Copenhagen, Denmark. p. 230-251,1996.

FEREZ, M.; HAFFAJEE, A.D.; GONCALVES C.; ALLARD, K.A.; SOM, S.; SMOTH, C.; GOODSON, J.M.; SOCRANSKY, S.S. Systemic doxycycline administration in the treatment of periodontal infections. J. Clin. Periodont. 26: p.784-792,1999.

FOOTE, C.S. Definition of type I and type II photosensitized oxidation. Photochem. Photobiol. 54(5): p. 659,1991.

GOMER, C.J.; RUCKER, N.; FERRARIO, A.; WONG, S. Properties and applications of photodynamic therapy. Rad. Res. 120(1): p.1-18, 1989.

HAMADA, S. Overview of the biology of Streptococcus mutans. In: Molecular microbiology and immunology of Streptococcus mutans. HAMADA, S.; MICHALEK, S.; KIYONO, H.; MENAKER, L.; MCGHEE, J. EDITORS. Elsevier Science Publishing Inc.p.7-20, New York 1986.

HAMILTON, I. R. Effect of changing environment on sugar transport and metabolism by oral bacteria. In: Sugar transport and metabolism by Gram positive bacteria, J. REIZER and A. PETERKOFSKY, EDS., CHICHESTER, England: Ellis Horwood, p. 94-133,1987.

HARTLLES, R.L.; McDONALD, N.D. The metabolism of the oral flora. The oxygen uptake and acid production by mixed human saliva in the presence and absence of glucose. Biochem. J. 47(1):p. 60-64,1950.

HARTREE,E.F. Determination of proteins: A modification of the Lowry method that gives a linear photometric response. Anal. Biochem. 48: p. 422-427,1972.

HEINONEN J.K.; LAHTI, R.J. A new and convenient colorimetric determination of inorganic orthophosphate and its application to the assay of inorganic pyrophosphatase. Anal. Biochem. 113(2): p.313-317,1981.

HENDERSON, B.W.; DOUGHERTY, T.J. How does photodynamic therapy work ? Photochem. Photobiol. 55(1): p.145-157,1992. 
HIRASAWA, M.; TAKADA, K. Susceptibility of Streptococcus mutans and Streptococcus sobrinus to cell wall inhibitors and development of a novel selective medium for S. sobrinus. Caries Res. 36(3): p.155-160,2002.

HOEBEKE, M. The importance of liposomes as models and tools in the understanding of photosensitization mechanisms. J. Photochem. Photobiol. 28: p.189-196,1995.

HOLT, J.G.; KRIEG, N.R.; SNEATH, P.H.A.; STALEY, J.T.; WILLIAMS, S.T. Eds. Bergey's manual of determinative bacteriology. $9^{\text {th }}$ ed. Williams \& Wilkins: Baltmore, Maryland; p.20 \& 527-558, 1994.

HRIMECH, M,; MAYRAND, D,; GRENIER, D.; TRAHAN, L. Xylitol disturbs protein synthesis oncluding the expression of HSP-70 and HSP-60, in Streptococcus mutans. Oral. Microbiol. Immunol. 15: p. 249-257.

JACQUES, S.L. Laser-tissue interactions: Photochemical, photothermal, and photomechanical. Surg. Clin. North. Am. 72(3): p. 531-58,1992.

JARRATT, M.; HUBLER, W.; PANEK W. Dye-Light Phototherapy of viral, bacterial, and fungal infections. In: The Science of Photomedicine. Regan J.D. and Parrish J.A. Plenum Press. p. 561 ,New York,1982.

JEFFERSON, K.K.; What drives bactéria to produce a biofilm? FEMS Microbiol. Lett.. 236(2): p.163-73, 2004.

JOHNSON, N.W. Introduction: the nature of the caries process and the need for markers of risk. In: Risk markers for oral diseases. Dental Caries. Markers of high an low risk groups and individuals. JOHNSON, N.W. Ed. Cambridge University Press: Cambridge. V.1, p. 1-12, 1991.

JORI, G. Tumour photosensitizers: approaches to enhance the selectivity and efficiency of photodynamic therapy. J. Photochem. Photobiol. 36: p.87-93,1996.

KATZ, S.; McDONALD, J. Jr.; STOOKEY, G. K. Preventive Dentistry in Action. DCP Publishing. $3^{\text {rd }}$. ed. p.340. New Jersey, 1979.

KAWADA, K.; YONEI, T.; UEOKA, H.; KIURA, K.; TABATA, M.; TAKIGAWA, N.; HARADA, M.; TANIMOTO, MComparison of chemosensitivity tests: Clonogenic Assay versus MTT Assay. Acta Med. Okayama. 56:(3) p.129-134,2002.

KESSEL, D.; LUO, Y. Photodynamic therapy: a mitochondrial incucer of apoptosis. Cell Death Differ. 6(1):p.28-35,1999.

KOCHEVAR, I.E.; LAMBERT, C.R.; LYNCH, M.C.; TEDESCO, A.C. Comparison of photosensitized plasma membrane damage caused by singlet oxygen and free radicals. Biochim. Biophysic. Acta. 1280(2): p.223-230,1996.

KOLENBRANDER, P.E. Oral microbial communities: biofilms, interactions, and gene systems. Annu. Rev. Microbiol.. 54: p.413-437,2000.

KÖNÖNEM, E.; ASIKAINEN, S.; SAARELA, M.; KARJELAINEN, J.; JOUSIMIES- 
SOMER, $H$. The oral Gram negative anaerobic microflora in young children: longitudinal changes from edentulous to dentate mouth. Oral Microbiol. Immunol. 9: p.136-141,1994.

KÖNÖNEM, E.; KANERVO, A.; TAKALA, A. ASIKAINEN, S.;JOUSIMIES-SOMER, H. Establishment of oral anaerobes during the first year of life. J. Dent. Res. 78: p.1634$1639,1999$.

KRASSE, B. Risco de cárie - Um guia prático para avaliação e controle. $2^{a}$ edição. Quintessence Editora. p.113,1998.

LAKOWICZ, J.R. Principles of fluorescence spectroscopy. New York: Plenum Press. 1984.

LAEMMLI, U.K. Cleavage of structural proteins during the assembly of the head of bacteriophage T4. Nature. 227: p. 680-685,1970.

LARKIN, J.M.; DONALDSON, W.R.; KNOX, R.S.; FOSTER, T.H. Reverser intersystem crossing in rose Bengal II. Fluence dependence of fluorescence following 532 nm laser excitation. Photochem. Photobiol. 75: p. 221-228, 2002.

LEKE, N.; GRENIER, D.; GOLDNER, M.; MAYRAND, D. Effects of hydrogen peroxide on growth and selected propreties of Porphyromonas gingivalis. FEMS. Microbiol. Lett., 174: p. 347-353, 1999

LEN, A.C.L., HARTY, W.S.; JACQUES, N.A. Stress-responsive proteins are upregulated in Streptococcuys mutans during acid tolerance. Microbiol., 150: p. 1339-1351, 2004.

MACDONALD, I.J.; DOUGHERTY, T.J. Basic Principles of Photodynamic Therapy. J. Porph. Phthal. 5: p.105-129, 2001.

MAGALHÃES, P.P.; PAULINO, T.P.; THEDEI, G. Jr.; CIANCAGLINI, P. A Kinetic characterization of the P-type membrane ATPase from Streptococcus mutans. Comp. Biochem. Physiol. 140:p. 589-597,2005.

MAGALHÃES, P.P.; PAULINO, T.P.; THEDEI G.Jr.; LARSON, R.E.; CIANCAGLINI, P. A $100 \mathrm{KDa}$ vanadate and lanzoprazole-sensitive ATPase from Streptococcus mutans membrane. Arch. Oral Biol. 48: p.815 - 824 ,2003.

MALIK, Z.; LADAN, H.; NITZAN, Y. Photodynamic inactivation of Gram-negative bacteria: problems and possible solutions. J. Photochem. Photobiol. 14(3): p.262$266,1992$.

MARQUIS, R.E. Applied and ecological aspects of oxidative-stress damage to bacterial spores an the oral microbes. Sci. Prog.. 87:p.153-177,2004.

MARSH, P.D. Are dental diseases examples of ecological catastrophes? Microbiology. 149: p. 279-294,2003.

MARSH, P.D. Antimicrobial strategies in the prevention of dental caries. Caries Res. 27(1): p. 72-76,1993. 
MARSH, P.D.; BRADHAW D.J. Microbial community aspects of dental plaque. In: Dental Plaque Revisited: oral biofilms in health and disease. Edited by H. Newman and M. Wilson, p. 237-253. Bioline, Cardiff, UK,1993.

MARSH, P.D.; FEATHERSTONE, A.; MCKEE, A.S.; HALLSWORTH, A.S.; ROBINSON, C.; WEATHERELL, J.A.; NEWMAN, H.N. and PITTER, A.F.V. A microbiological study of early caries of approximal surfaces in school children. J. Dent. Res.. 68: p.1151-1154,1989.

MATEVSKI, D.; WEERSINK, R.; TENENBAUM, H.C.; WILSON, B.; ELLEN, R.P.; LÉPINE, G. Lethal photosensitization of periodontal pathogens by a red-filtered Xenon lamp in vitro. J. Periodontal Res. 38: p.428-435, 2003.

MATTHEWS, T.D.; NEWMAN, J.T.; SANGANDARES-BERNAL, F.; JUDDY, M.M.; $\mathrm{CHANH}$, T.C Photodinamic therapy of viral contaminants with potential for blood banking applications. Transfusion. 28: p.81-83,1988.

McNEILL, K.; HAMILTON I. R. Acid tolerance response of biofilm cells of Streptococcus mutans. FEMS Microbiol. Rev. 221(1): p. 25-30,2003.

MENAKER, L. Chemical composition of teeth. In: The Biologic Basis of Dental Caries: An oral biology textbook. Editors: Harper and Row Publishers Inc. Maryland. p. 149-185,1980.

MERCHAT, M.; SPIKES, J.D.; BERTOLONI, G.; JORI, G. Studies on the mechanism of bacteria photosensitization by meso-substituted cationic porphyrins. J. Photochem. Photobiol. 35: p.149-157,1996.

MEULEN, F.W.; IBRAHIN, K.; STERENBORG, H.G.; ALPHEN, L.V.; MAIKOE, A.; DANKERT, J. Photodynamic destruction of Haemophilus parainfluenzae by endogenously produced porphyrins. J. Photochem. Photobiol. 40(3): p.204-208, 1996.

MEYER-BETZ, F. Beobachtrungen an wochenchhr eineem eigenartigen mit muskallahmungen verbunden fall von hamoglobinurie. Dtosch. Arch. Klin. Med. 101: p. 85,1912 .

MIKKELSEN, L.; JENSEN, S.B.; JAKOBSEN, J. Microbial studies on plaque from carious and caries-free proximal tooth surfaces in a population with high caries experience. Caries Res.. 15: p. 428-435,1981.

MINNOCK, A.; VERNON, D.I.; SCHOFIELD, J.; GRIFFITHS, J.; PARISH, J.H.; BROWN, S.B. Photoinactivation of bacteria. Use of a cationic water-soluble zinc phthalocyanine to photoinactivate both Gram-negative Gram-positive bacteria. J. of Photochem. and Photobiol. B. 32: p.159-164, 1996.

MORO, F. Jules Francois: a life for ophthalmology (1907-1984). Metab. Pediatr. Syst. Ophthalmol. 9(2-4): p. 40-41, 1986.

MOSMANN, T. Rapid colorimetric assay for cellular growth and survival: application to proliferation and cytotoxicity assays. J. Immunol. Methods. 65(1-2): p.55$63,1983$. 
MURANT, R.S.; GIBSON, S.L.; HILF, R. Photosensitizing effects of Photofrin II on the sete-selected mitochondrial enzymes adenilate kinase and monoamine oxidase. Cancer Res. 47(16): p.4323-4328,1987.

NELSON, D.L.; COX, M.M. Lehninger Principles of Biochemistry, $3^{\text {rd }}$ ed., Worth Publishers: New York,2000.

NUNES, S.M.T.; SGUILLA, F.S.; TEDESCO, A.C. Photophysical studies of zinc phthalocyanine and chloroaluminium phthalocyanine incorporated into liposomes in the presence of additives. Braz. J. Med. Biol. Res. 37: p. 273-284, 2004.

O'NEIL, J.; WILSON, M.; WAINWRIGHT, M. Comparative antiestreptococcal activity of photobactericidal agents. J. Chemoth. 15(4): p. 329-334, 2003.

OLIVEIRA, C.A.; MACHADO, A.E.; PESSINE, F.B. Preparation of $100 \mathrm{~nm}$ diameter unilamellar vesicles containing zinc phthalocyanine and cholesterol for use in photodynamic therapy. Chem. Phys. Lipids. 133(1): p.69-78, 2005.

OLSVIK, B.; TENOVER, F.C. Tetracycline resistance in periodontal pathogens. Clin. Infec. Diseases. 16: p.310-313,1993.

PACZKOWSKI, J.; LAMBERTS, J.J.; PACZKOWSKA, B.; NECKERS, D.C. Photophysical properties of rose bengal and its derivatives (XII). J. Free Rad. Biol. Med. 1(5-6): p. 341-351,1985.

PAULINO, T.P.; ANDRADE, R.O.; BRUSHI-THEDEI, G.; THEDEI, G.Jr.; CIANCAGLINI, P. The Effect of Carbon Source and Fluoride Concentrations in the Streptococcus mutans Biofilm Formation. Biochem. Mol. Biol. Educ. 32: p. 331335, 2004a.

PAULINO, T.P.; CARDOSO, M.Jr..; BRUSHI-THEDEI, G.; CIANCAGLINI, P.; THEDEI, G. Jr. Fermentable and non fermentable sugars: a simple experiment of anaerobic metabolism. Biochem. Mol. Biol. Educ. 31: p.180-184, 2003.

PAULINO, T.P.; RIBEIRO, K.F.; THEDEI, G.Jr.; TEDESCO, A.C.; CIANCAGLINI, P. Use of hand held photopolymerizer to photoinactivate Streptococcus mutans. Arch. Oral Biol. 50: p. 353-359, 2005.

PAULINO, T.P.; THEDEI-JR G.; TEDESCO, A.C.; CIANCAGLINI, P. Uso de agentes fotossensíveis no tratamento de microrganismos patogênicos ativados por luz visível oriunda de foto-polimerizadores ou sistemas led de irradiação luminosa. Instituto Nacional de Propriedade Industrial - INPI. Petição de Patente de Invenção $\mathrm{n}^{0}$ : 851899664/00 de 28 de janeiro de 2004, com PI n: 0404223-9. 2004b.

PENNING, L.C.; DUBBELMAN, T.M. Fundamentals of photodynamic therapy: cellular and biochemical aspects. Anticancer Drugs. 5(2): p. 139-146, 1994.

PEDERSEN, A.O.; SCHONHEYDEER, F.; BRODERSEN, R. Photooxidation of human serum albumim and its complex with bilirubin. Eur. J. Biochem. 72: p. 213221, 1977. 
PITCHER, D.G.; SAUNDERS, N.A.; OWEN, R.J. Rapid extraction of genomic DNA with guanidinium thiocyanate. Lett. Appl. Microbiol. 8: p.151-156, 1989.

PRINSZE, C.; TIJSSEN, K.; DUBBELMAN, T.M.; VAN STEVENINCK, J. Potentiation of hyperthermia-induced haemolysis of human erythrocytes by photodynamic treatment. Evidence for the involvement of the anion transporter in this synergistic interaction. Biochem. J.. 277: p.183-188,1991.

RADCLIFE, C.E.; AKRAM, N.C.; HURREL, F.; DRUCKER, B.D. Effects of nitrite and nitrate on the growth and acidogenicity of Streptococcus mutans. J. Dent. 30: p. 325331,2002 .

REDDI, E., ZHOW, C., BIOLO, R., MENEGALDO, E.; JORI, G. Lipossome or LDLadministered $\mathrm{Al}(\mathrm{III})$-phtalocyanine as a ohotodynamic agent for tumours. I. Pharmacokinetic proprieties and phototherapeutic efficiency. Br. J. Cancer. 61: p. 407-411,1990.

REGAN, J. D.; PARRISH, J. A. The science of Photomedicine. Plenum Press. New York and London, 1982.

RICHELLI, F.; GOBBO, S.; JORI, G.; MORENO, G.; VINZENS, F.; SALET, C. Photosensitization of mitochondria by liposome-bound porphirins. Photochem. Photobiol. 58: p. 53-62, 1993.

RODRIGUÉZ, H.B.; LAGORIO, M.G.; ROMÁN, E.S. Rose Bengal absorbed on microgranular cellulose: evidence on fluorescent dimmers. Photochem. Photobiol. 3: p. 674-680, 2004.

ROLLA, G. Why is sucrose so cariogenic? The role of glucosyltransferase and polysaccharides. Scand. J. Dent. Res. 97(2): p.115-119,1989.

ROSENTHAL, I. Phtalocyanines as photodynamic sensitizers. Photochem. Photobiol. 53: p. 859-870,1989.

ROSS, W.N.; SALZBERG, B.M.; COHEN, L.B.; GRINVALD, A.; DAVILLA, H.V. and WANG, C.H. A large change in dye absorption during the action potential. Biophys. J. 14: p. 983-986, 1977.

ROVALDI, C.R.; PIEVSKY, A.; SOLE, N.A.; FRIDEN, P.M.; ROTHSTEIN, D.M.; SPACCIAPOLI, P. Photoactive porphirin derivative with broad-spectrum activity against oral pathogens in vitro. Antimic. Ag. Chemoth. 44(12): p. 3364-3367, 2000.

RUCK, A., BECK, G., CACHOR, K., AKGUN, N., GSCHWIND, M.H., STAINER, R. Dynamic fluorescence changes during photodynamic therapy in vivo and in vitro of hydrophiky Al (II) phtalocyanine tetrasulphonated and lipophylic Zn (II) phthalocianine administred in lipossomes. J. Photochem. Photobiol. B: Biol. 36: p. 127-133, 1996.

SATROM, K.D.; MORRIS, M.A.; CRIGGER, L.P. Potential retinal hazards of visiblelight photopolymerization units. J. Dent. Res. 66(3): p. 731-736,1987.

SCOLARO, L.M.; CASTRICIANO, M.; ROMEO, A.; PATANĖ, S.; CEFALÌ, E.; ALLEGRINI, M. Aggregation behavior of protoporphyrin IX in aqueous solutions: 
clear evidence of vesicle formation. J. Phys. Chem. B. 106: p. 2453-2459, 2002.

SHARMAN, W.M.; ALLEN, C.M.; VAN LIER, J.E. Photodynamic therapeutics: basic principles and clinical applications. Drug Discov. Today 4(11): November,1999.

SHAWAR, R.; COOPER, B.H. Comparative kinetics of hematoporphirin derivative uptake and susceptibility of Bacillus subtilis and Streptococcus faecalis to photodynamic action. Photochem. Photobiol. 52(4): p. 825-830, 1990.

SIBATA, M.N.; TEDESCO, A.C.; MARCHETTI, J.M. Photophysicals and photochemicals studies of zinc(II) phthalocyanine in long time circulation micelles for photodynamic therapy use. Eur. J. Pharm. Sci. 23(2): p. 131-138, 2004.

SING, J.K.; DHAWAHIR, F.E.; HAMID, A.F.; CHELL, P.B. The use of dye in ophthalmology. J. Audiov. Media Med. 27: p.62-67.

SKILES, H.; JUDDY, M.M.; NEWMAN, T.J. Photodynamic inactivation of viruses with hematoporphyrin derivative. Ann. Meet. Am. Soc. Microbiol. p. 8,1985.

SMITH, D. Dental caries vaccines: prospects and concerns. Crit. Rev. Oral Biol. Med. 13(4): p.335-349, 2002.

SOCRANSKY, S.S.; MANGANIELLO, S.D. The oral microbiota of man from birth to senility. J. Periodontol.; 42: p. 485-496,1971.

SOUKOS, N.S.; WILSON, M.; BURNS, T.; SPEIGHT, P.M. Photodynamic effects of toluidine blue on human keratinocytes and fibroblastsand Streptococcus sanguis evaluated in vitro. Lasers Surg. Med. 18: p. 253-259, 1996.

SPATAFORA, G.; ROHRER, K.; BARNARD, D.; MICHALEK, S.. A Streptococcus mutans mutant that syntetizes elevated levels of intracellular polysaccharide is hipercariogenic in vivo. Infect. Immun. 63: 7; p. 2556-2563, 1995.

SPILLER, W. Singlete oxygen quantum yields of differnet photosensitizers in polar solvents and micellar solution. J. Porph. Phatal. 2: p. 145-148, 1998.

STIEL, H.; TEUCHNER, K.; PAUL, A.; LEUPOLD, D.; KOCHEVAR, I.E. Quantitative comparison of excited state properties and intensity-dependent photosensitization by rose bengal. J. Photochem. Photobiol. B. 33: p.245-254,1996.

SZOCS, K.; GABOR, F.; CSIK, G.; FIDY, J. ס-Aminolevulinic acid-induced porphyrin synthesis and photodynamic inactivations of Escherichia coli B. J. of Photochem. Photobiol. B. 50: p.8-17,1999.

STERNBERG, E.D.; DOLPHIN, D. Second generation photodynamic agents: a review. J. Clin. Laser. Med. Surg. 11: p. 233-241,1993.

THACH, A.B. Laser injuries of the eye. Int. Ophthalmol. Clin. 39:p13-27,1999.

TREMBLAY, J.F.; DUSSAULT, S.; VIAU, G.; GAD, F.; BOUSHIRA, M.; BISSONNETTE, R. Photodynamic therapy with toluidine blue in Jurkat cells: cytotoxicity, subcellular localization and apoptosis induction. Photochem. Photobiol. 
Sci. 1(11):p852-856,2002.

USACHEVA, M.N.; TEICHERT, M.C.; BIEL, M.A. Comparison of the methylene blue and toluidine blue photobactericidal efficacy against Gram-positive and Gramnegative microrganisms. Lasers Surg. Med. 29: p165-173,2001.

VAN DER MEI, H.C.; SOET, J.J.; GRAAFF, J.; ROUXHET, P.G.; BUSSCHER, H.J. Comparison of the physicochemical surface properties of Streptococcus rattus with those of other mutans streptococcal species. Caries Res. 25(6):p. 415- 23,1991.

VEMURI, S.; RHODES, C.T. Preparation and characterization of liposomes as therapeutic delivery systems: a review. Pharm. Acta Helv. 70: p.95-111,1995.

VENEZIO, F.R.; DI VENNENZO, C.; SEHRMAN, R.; REICHMAN, M.; ORIGITANO, T.; THOMPSON, K.; REICHMAN, O.H. Bactericidal effects of photoradiation therapy with hematoporphirin drivative. J. Infec. Dis. 151: p. 166-169,1985.

WALLMAN, C.; KRASSE, B.; BIRKHED, D.; DIACONO, S. The effect of monitored chlorhexidine gel treatment on mutans streptococci in margins of restorations. J. Dent. 26(1): p. 25-30, 1998.

WATCHTER, E.; DEES, C.; HARKINS, J.; SCOTT, T.; PETERSE, M.; RUSH, R.E.; CADA, A. Topical rose bengal: Pre-clinical evaluation of pharmacokinetics and safety. Lasers Surg. Med. 32(2): p.101-110,2003.

WATT, R.; SHEIHAM, A Inequalities in oral health: a review of the evidence and recommendations for action. Br. Dent. J. 187:p. 6-12,1999.

WEGMAN,M. R.; EISENBERG, A.D.; CURZON, M.E.; HANDELMAN, S.L. Effects of fluoride, lithium and strontium on intracellular polysaccharide accumulation in $S$. mutans and A. viscosus. J. Dent. Res. 63(9): p.1126-1129,1984.

WHILEY, R.A.; BEIGHTON, D. Current classification of the oral streptococci. Oral Microbiol. Immunol. 13: p. 195-216,1998.

WILSON, M.; DOBSON, J.; SARKAR, S. Sensitization of periodontophatogenic bacteria to killing by light from a low power laser. Oral Microbiol. Immunol. 8: p.182187, 1993.

WISE, R.; The development of new antimicrobial agents. Br. Med. J. 317: p. 643644, 1998.

WOOD, S.; NATTRESS, B.; KIRKHAM, J.; SHORE, R.; BROOKES, S.; GRIFFITHS, J.; ROBINSON, C. An in vitro study of the use photodynamic therapy for the treatment of natural oral plaque biofilms formed in vivo. J. Photochem. Photobiol. 50: p. 1-7, 1999.

ZOEPF, T.; JACKOBS, R.; ARNOLD, J.C.; APEL, D.; ROSENBAUM, A.; RIEMANN, J.F. Photodynamic therapy for palliation of nonresectable bile duct cancer-preliminary results with a new diode laser system. Am. J. Gastroenterol. 96(7): p. 2093-2097, 2001 
7. ANEXOS 


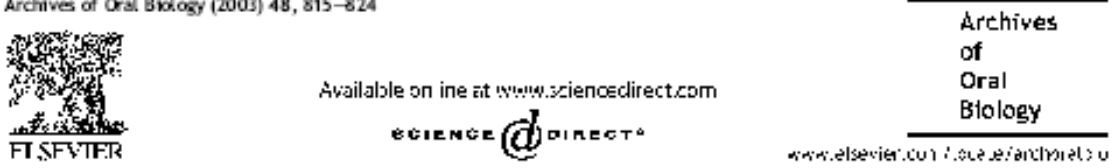

\title{
A $100 \mathrm{kDa}$ vanadate and lanzoprazole-sensitive ATPase from Streptococcus mutans membrane
}

\author{
Prislaine P. Magalhães ${ }^{a}$, Tony P. Paulino ${ }^{a}$, Geraldo Thedei Jr. ${ }^{b}$,
} Roy E. Larsonc, Pietro Ciancaglini $i^{\mathrm{a}, *}$

\begin{abstract}
"Departamento de Quimica, Facuidade de Filasofia Ciências e Letras de Ribeirāo Preto (FFCLRP), Universidade de Sōo Paulo (USP), 14040-901 Ribeirāo Preto, SP, Brazil

Instituto de Ciências Biológicas e da Saúde, Universidade de Úberaba, Uberaba, MG, Brazil 'Departamento de Biologia Celuiar e Molecular e Bioagentes Patogênicos, Faculdade de Medicina de Ribeirão Preto (FMRP), Universidade de São Paulo (USP), Ribeirão Preto, SP, Brazil

Accepted 16 June 2003

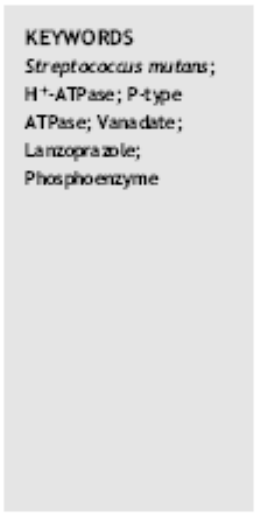

Introduction

It is known that Streptococous mutans comprises a substantial part of the cell count in dental plaques subject to caries development, and its importance in dental caries aetiology is unquestionable. ${ }^{1}$ The cariogenic potential of these bacteria is due to the production of organic acids derived from the metabolism of sucrose, fructose and glucose, among

"Corresponding suthor. Tel.: +55-16-602-3753; fax: +55-16-633-8151.

E.mail address: pietr osffelrp.upp.br (P. Ciencaglini). other sugars. Amongst the acids formed, lactic and acetic acid account for more than $95 \%$ of the total anions produced by S. mutans and Streptococcus sobrinus. ${ }^{2}$

The acid generation capacity (acidogeny) implies the necessity of mechanisms for these organisms to tolerate an acidic environment (acidurance). It is known that this behaviour depends, at least in part, on the ATPases bcated in the plasma membrane. These enzymes are responsible for cytoplasmic proton extrusion. ${ }^{3-8}$ The $\mathrm{F}_{1} \mathrm{~F}_{\mathrm{o}}$-ATPase of Streptococcus faecalis, described as the ma in enzyme responsible for this translocation activity, was purified. ${ }^{9}$ In 
addition, the operon that encodes of S. mutans $\mathrm{F}_{1} \mathrm{~F}_{\mathrm{o}}$-ATPase subunits was cloned and sequenced. ${ }^{10}$ Previous studies showed that the ATPase activity present at $S$. mutans plasma membrane increases when this organism grows in an acidic environment, probably in an attempt to remove the cytoplasmic protons and to protect the $\mathrm{pH}$ sensitive enzymes, mainly those of the glycolytic pathway. ${ }^{4,5}$

The subunit $F_{1}$ of $F_{1} F_{0}$-ATPase has a molecular weight of about $385 \mathrm{kDa}$ and comprises five different subunits, $\alpha, \beta, \gamma, \delta$, and $\epsilon$ with correspondent molecular weights of $60,55,37,20$ and $12 \mathrm{kDa}$, keeping the relation of $3: 3: 1: 1: 1$, respectively. ${ }^{3}$ This protomer can hydrolyze ATP, GTP and ITP. The $F_{o}$ subunit of this ATPase includes a very hydrophobic domain, located in the plasma membrane, consisting of three different proteins called M27, M15 and M6, with molecular weights of 27,15 and $6 \mathrm{kDa}$, respectively. ${ }^{3}$ This domain is responsible for the formation of the proton translocation channel in the bacterial plasma membrane and is the target of oligomycin and $\mathrm{N}, \mathrm{N}$-dicyclohexyl carbodiimide (DCCD), strong inhibitors of proton translocation ATPase activity. ${ }^{3}$ It is important to mention that the inhibition of ATPase activity by oligomycinoccurs only when the subunits $F_{o}$ and $F_{1}$ are connected. ${ }^{11}$

Although an engineered mutant strain producing $50 \%$ of normal $\mathrm{F}_{1} \mathrm{~F}_{\mathrm{o}}$-ATPase activity showed prolonged lag phase of growth, it is capable of grow and extrusion of protons, keeping the intracellular $\mathrm{pH}$ in one $\mathrm{pH}$ unit of extracellular ambient and lowering the culture $\mathrm{pH}$ from 7 to 4 . This suggests the existence of other proton-translocating ATPases or another cellular mechanism that keeps the cytosolic $\mathrm{pH}$ neutral during the micro-organism growth. ${ }^{12}$

Thus, other ATPases besides the $F_{1} F_{0}$-ATPase may contribute to intracellular $\mathrm{pH}$ regulation in S. mutans. For instance, these ATPase could be a $\mathrm{H}^{+}, \mathrm{K}^{+}$-ATPase and $\mathrm{H}^{+}$-ATPase (both P-type ATPases) widely described in yeast and plant plasma membrane. ${ }^{13-16}$

The $\mathrm{H}^{+}$-ATPase of the yeast plasma membrane is structurally and functionally a P-type, like $\mathrm{Na}^{+}, \mathrm{K}^{+}$. ATPase, $\mathrm{H}^{+}, \mathrm{K}^{+}$-ATP ase and $\mathrm{Ca}^{2+}$-ATPase of animals cells and $\mathrm{H}^{+}$-ATPases of plant cells. In their reaction mechanism, ATP is hydrolyzed to ADP and inorganic phosphate ( $\mathrm{Pi})$, via a covalent intermediate $\beta$-aspartil phosphate. ${ }^{17,18}$ These ATPases can have multiple subunits like the $\mathrm{Na}^{+}, \mathrm{K}^{+}$-ATPase, which is comprises by three subunits $\alpha, \beta$, and $\gamma^{19-23}$ or just one subunit, like the $\mathrm{Ca}^{2+}$-ATPases and the $\mathrm{H}^{+}$. ATPases. These enzymes, found in Schizosaccharomyces pombe, Saccharomyces cerevisiae, and Neurospora crassa, are composed of one $100 \mathrm{kDa}$ polypeptide chain (similar to subunit $\alpha$ of $\mathrm{Na}^{+}, \mathrm{K}^{+}$. ATPase), with 10 transmembrane domains. ${ }^{17,24,25}$
Recently, the complete sequence of the Streptococcus pneumoniae genome showed the presence of P-type ATPases, whose functions are the transport of calcium, copper and metal/cation. ${ }^{26}$ One vanadatesensitive $\mathrm{K}^{+}$-ATPase was described for $\mathrm{S}$. faecal is, with molecular weight of $78 \mathrm{kDa},{ }^{27}$ but no evidence of a P-type $\mathrm{H}^{+}$-ATPase was found in the bacterium.

The main objective of this paper is to demonstrate the existence of a P-type ATPase with a possible $\mathrm{H}^{+}$transport or $\mathrm{H}^{+}$, ion antiport activity in the membrane of S. mutans which may work in conjunction with the $\mathrm{F}_{1} \mathrm{~F}_{\mathrm{o}}$-ATPase, on the regulation of cytoplasmic $\mathrm{pH}$ in this micro-organism.

\section{Materials and methods}

All solutions were prepared by using Millipore Milli- $Q$ ultrapure apyrogenic water. Sodium dodecyl sulfate (SDS), 3-[(3-cholamidopropyl)dimethylamino]1-propane sulfonate (CHAPS), 3-[(3-cholamidopropyl)dimethylamino]-2-hydroxy-1-propane sulfonate (CHAPSO), $t$-octylphenoxypolyethoxyethanol (Triton X-100), octylphenoxypolyethoxyethanol (Triton X114), polyoxyethylene-sorbitan monolaurate (Tween 20), sodium deoxicholate, sodium cholate, polyoxyethylene-9-lauryl ether $\left(\mathrm{C}_{12} \mathrm{E}_{9}\right)$, tris [hydroxymethyl] aminomethane (Tris), bis[2-hydroxyethyl] iminotris[hydroxymethyl]methane (Bis-Tris), imidazol, trichloro acetic acid (TCA), lysozyme, 2- $\mathrm{N}$-morpholine ethanesulfonic acid (MES), 2-amino-2-methylpropan-1-ol (AMPOL), $\alpha$-naphthyl phosphate, Fast Blue RR, oligomycin, ouabain, sodium azide, ethacrynic acid, furosemide, bafilomycin, thapsigargin, lansoprazole, $\mathrm{N}, \mathrm{N}$-diciclohexil carbodiimide, adenosine $5^{\prime}$-triphosphate disodium salt (ATP), sodium orthovanadate, $p$-nitrophenylphosphate disodium salt (PNPP), deoxyribonuclease I, protease inhibitor cocktail and bovine serum albumin (BSA) were purchased from Sigma. Dodecyloctaethyleneglycol $\left(C_{12} E_{8}\right)$ was purchased from Calbiochem. 1-o-nOctyl- $\beta$-D-glucopyranoside (glucopyranoside) and $\mathrm{N}$-ethylmaleimide (NEM) were purchased from ACROS Organics. Tryptic soy agar (TSA) was from DIFCO. [ $\gamma-{ }^{32}$ P]ATP $(5000 \mathrm{Ci} / \mathrm{mmol})$ was purchased from Amersham Biosciences. Analytical grade reagents were used without further purification.

\section{Strain}

S. mutans ATCC 25175 was purchased from the Fundação André Tosello, Campinas, SP, Brazil.

\section{Growth conditions}

S. mutans were kept stocks at $-20{ }^{\circ} \mathrm{C}$ in $40 \%(\mathrm{v} / \mathrm{v})$ glycerol or in a candle jar for frequent utilization 
upon weekly subculturing on TSA. Large amounts of cells were obtained from $1 \mathrm{I}$ cultures of complete medium described by Harper and Loesche ${ }^{28}$, grown in a candle jar with magnetic stirring until the $\mathrm{pH}$ reached 4.0. Growth curves were constructed inoculating $1 \mathrm{ml}$ of $\sim 10^{9}$ cells $/ \mathrm{ml}$ in $1 \mathrm{l}$ of complete medium. For each point of the curve ( $2 \mathrm{~h}$ interval), samples were collected for $\mathrm{pH}$ and turbidity monitoring and membrane ATPase activity determination.

\section{Extraction of ATPase membrane fraction}

The $\mathrm{H}^{+}$-ATPase rich membrane fractions were obtained as described by Bender et al. ${ }^{29}$ with the modifications described further.

Approximately $1.0 \mathrm{~g}$ (wet weight) of cells was washed twice with $15 \mathrm{ml}$ of water and centrifuged at $9000 \times g$ for $10 \mathrm{~min}$ at $20^{\circ} \mathrm{C}$. The pellet was weighed, resuspended and homogenized in $25 \mathrm{mM}$ MES, pH 6.2, buffer containing $97 \mathrm{mM} \mathrm{NaSCN}$. The absorbance (at $700 \mathrm{~nm}$ ) of the solution was monitored until attaining a value of about 0.4 and homogenized. Lysozyme $(0.4 \mathrm{mg} / \mathrm{ml})$ was then added. The mixture was incubated for $3 \mathrm{~h}$ at $37^{\circ} \mathrm{C}$ with gentle agitation and centrifuged at $9000 \times g$ for $20 \mathrm{~min}$ at $4^{\circ} \mathrm{C}$. The pellet obtained was resuspended and homogenized in $50 \mathrm{mM} \mathrm{MES}$, $\mathrm{pH}$ 6.2, buffer containing $10 \mathrm{mM} \mathrm{MgSO}_{4}$ and $0.8 \mathrm{M}$ $\mathrm{NaCl}$ (osmotic buffer) and sonicated (tip sonicator, Vibracell $600 \mathrm{~V}, 50 \%$ amplitude) for $20 \mathrm{~min}$ at $4{ }^{\circ} \mathrm{C}$ (50 ml buffer/g cell). The cell lysis was monitored by light microscopy. The homogenate was incubated with gentle agitation for $45 \mathrm{~min}$ at room temperature with $25 \mathrm{U} \mathrm{DNase} / \mathrm{ml}$ homogenate and $0.25 \mathrm{ml}$ protease inhibitor cocktail/g cell.

The mixture was ultracentrifuged at $100,000 \times g$ for $1 \mathrm{~h}$ at $4{ }^{\circ} \mathrm{C}$. The pellet containing the membrane fraction was resuspended in $25 \mathrm{mM}$ MES buffer, $\mathrm{pH}$ 6.2 , containing $97 \mathrm{mM} \mathrm{NaSCN}$ and again incubated with lysozyme $1: 1$ ( $\mathrm{mg}$ protein $/ \mathrm{mg}$ lysozyme) for $2 \mathrm{~h}$ at room temperature with gentle agitation. The membrane homogenate was ultracentrifuged under the same conditions and the pellet was resuspended in $40 \mathrm{ml} 50 \mathrm{mM}$ Tris $-\mathrm{HCl}, \mathrm{pH} \mathrm{7.5}$, buffer containing $10 \mathrm{mM} \mathrm{MgSO}_{4}$ (stock buffer) and stored at $-20^{\circ} \mathrm{C}$.

\section{Protein analysis}

Protein concentrations were estimated according to the Hartree method ${ }^{30}$ in the presence of $2 \%(\mathrm{w} / \mathrm{w})$ SDS using BSA standard.

\section{Enzyme assays}

ATPase activity was assayed discontinuously at $37^{\circ} \mathrm{C}$ by quantification of phosphate release as described by Heinonen and Lahti ${ }^{31}$, adjusting the assay medium to a final volume of $1.0 \mathrm{ml}$. The reaction was initiated by the addition of the enzyme, stopped with $0.5 \mathrm{ml}$ of cold $30 \%$ TCA at appropriate time intervals and centrifuged at $4000 \times g$ immediately prior to phosphate determination. Standard conditions were $50 \mathrm{mM}$ Bis-Tris buffer, $\mathrm{pH}$ 6.5, containing $5 \mathrm{mM}$ ATP and $5 \mathrm{mM}$ $\mathrm{MgCl}_{2}$, p-nitrophenylphosphatase (PNPPase).

Activity was assayed discontinuously at $37^{\circ} \mathrm{C}$ in a Genesys 2 spectrophotometer by monitoring the liberation of $p$-nitrophenolate ion $\left(\varepsilon_{1 \mathrm{M}, \mathrm{pH} 13}=\right.$ $17,600 \mathrm{M}^{-1} \mathrm{~cm}^{-1}$ ) at $410 \mathrm{~nm}$, in $50 \mathrm{mM}$ Bis-Tris buffer, $\mathrm{pH} 6.5$, containing $10 \mathrm{mM}$ PNPP and $10 \mathrm{mM} \mathrm{MgCl} 2$ in a final volume of $1.0 \mathrm{ml}$. The reaction was initiated by the addition of the enzyme and stopped with $1.0 \mathrm{ml}$ of $1 \mathrm{M} \mathrm{NaOH}$. For both activities the determination was carried out in triplicate and the initial velocities were constant for at least $30 \mathrm{~min}$, provided that less than $5 \%$ of substrate was hydrolyzed. Controls without added enzyme were included in each experiment to quantify the non-enzymatic hydrolysis of the substrate. One enzyme unit (1 $\mathrm{U})$ is defined as the amount of enzyme hydrolyzing $1.0 \mathrm{nmol}$ of substrate per minute at $37^{\circ} \mathrm{C}$.

\section{Solubilization study of ATPase rich membrane fraction}

Samples of bacterial membrane were mixed with appropriate concentrations of detergent and at predetermined intervals, $0.5 \mathrm{ml}$ aliquots were removed and centrifuged at $100,000 \times g$ for $1 \mathrm{~h}$. The activity before centrifugation and the amount of protein and activity in the supernatant and resuspended pellet were assayed and these numbers were used to calculate the percent solubilization (the data obtained shows an average of triplicate determinations in which $P<0.05$ was considered to be statistically significant). This protocol was utilized with different detergents, used above its critical micellar concentration (CMC), using $1.0 \mathrm{mg} / \mathrm{ml}$ of membrane protein at $25^{\circ} \mathrm{C}$ for $30 \mathrm{~min}$ of incubation.

After solubulization, aliquots of all solubilized extracts were stored in an ice bath or frozen and from time to time (at 1 week) ATPase activity was monitored and the stability of solubilized enzyme was estimated.

\section{SDS-PAGE}

The molecular mass of proteins was estimated by SDS-PAGE (10 or $7 \%$ ) with $5 \%$ stacking gel, according to Laemmli ${ }^{32}$, using silver nitrate for protein staining. ${ }^{33}$ Myosin (205 kDa), $\beta$-galactosidase (116 kDa), phosphorylase B $(97.4 \mathrm{kDa})$, bovine serum albumin 
(66 kDa), egg albumin ( $45 \mathrm{kDa})$ and carbonic anydrase $(29 \mathrm{kDa})$ were used as molecular markers. Protein samples were concentrated using Microcon 30 (Amicon).

For enzyme activity staining, the gel was incubated in $50 \mathrm{mMTris}-\mathrm{HCl}$ buffer, $\mathrm{pH} 7.5$ during $90 \mathrm{~min}$ (three changes), at $25^{\circ} \mathrm{C}$, with gentle agitation, for protein renaturation. Phosphohydrolytic activity on the gel was detected in $50 \mathrm{mMBis}$-Tris buffer, $\mathrm{pH} 6.5$, containing $5 \mathrm{mM} \mathrm{MgCl}_{2}, 0.12 \%$ (w/v) 1-naphthylphosphate and $0.12 \%(\mathrm{w} / \mathrm{v})$ Fast Blue RR, at $37^{\circ} \mathrm{C}$.

\section{Phosphoenzyme detection}

The reaction mixture containing $50 \mu \mathrm{g}$ total protein in $50 \mathrm{mM}$ Bis-Tris, $\mathrm{pH} 6.5$, containing $5 \mathrm{mM} \mathrm{MgCl} 2$, $2 \mu \mathrm{Ci}$ of $\left[\gamma^{32} \mathrm{P}\right] \mathrm{ATP}, 5 \mathrm{mM}$ of cold ATP with or without $3 \mu \mathrm{M}$ of orthovanadate was incubated for $5 \mathrm{~min}$, at $37^{\circ} \mathrm{C}$. The reaction was started with addition of the enzyme in the reaction medium and stopped by the addition of ice-cold 50\% (w/v) TCA. The precipitate was collected by centrifugation at $20,000 \times g$ for $10 \mathrm{~min}$ at $4^{\circ} \mathrm{C}$, dissolved in SDS-PAGE buffer $\mathrm{r}^{32}$ and neutralized by ammonium vapour and the electrophoresis was performed as described earlier.

Incorporation of $\left[\gamma^{-{ }^{32}} \mathrm{P}\right]$ into protein was visualized by autoradiography of the dried gel by exposure on a storage phosphor screen for 5 days that was subsequently scanned using the STORM 840 Phospholmager (Molecular Dynamics).

\section{$\mathrm{pH}$ sensitivity of catalysis}

The effect of pH on ATPase activity was measured in a $50 \mathrm{mM}$ buffer over a $\mathrm{pH}$ range between 5.0 and 9.5. MES buffer was used in a range of $5.0-6.0$, BisTris from 6.0 to 6.5; Imidazol from 6.5 to 7.5 ; Tris from 7.0 to 9.0 and AMPOL from 8.5 to 9.5 . The $\mathrm{pH}$ of the reaction mixture was measured both before and after the assay and did not vary by more than 0.05 units. ATPase activity was assayed as described earlier.

\section{Effect of inhibitors on ATPase activity}

ATPase activity was determined in the presence of different inhibitors as described earlier. Inhibitors used were: lanzoprazole, orthovanadate, ouabain, sodium azide, ethacrynic acid, furosemide, bafilomycin, tapsigargin, DCCD and oligomycin. The inhibitors solutions were prepared previously in reaction medium buffer and the ATPase activity was assayed as described earlier.

\section{Results}

Fig. 1 shows the growth of $S$. mutans as a function of culture time. In this figure, we observe a lag phase of $4 \mathrm{~h}$, followed by a log phase of $4 \mathrm{~h}$ and then, the stationary phase. The ATPase activity present in

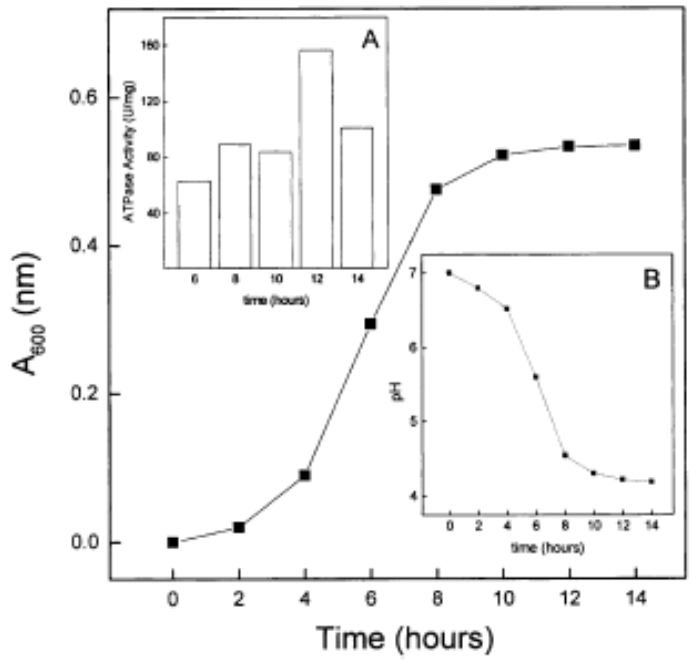

Figure 1 Growth curve of S. mutans. Cells of ATCC 25175 strain were cultured in complete medium and, at different time intervals, the absorbance of a sample was measured at $600 \mathrm{~nm}$. Inset A: ATPase activity of $S$. mutans membranes. Membrane fractions were isolated at different time intervals, and ATPase activity was measured. Inset $\mathrm{B}$ : $\mathrm{pH}$ variation in culture medium of S. mutans (for detail see "Materials and methods" section). Data are reported as the mean of triplicate experiments in which $P<0.05$. 
the membrane fraction was determined in bacterial samples collected during the log and the stationary phases of growth. The enzymatic activity slightly increased during the log phase, stabilized in the beginning of the stationary phase and increased significantly after $12 \mathrm{~h}$ of culture (Fig. 1, inset A). When the culture was done in the buffered medium ( $50 \mathrm{mM}$ MOPS, $\mathrm{pH} 7.0$ ), the ATPase activity did not show this increase, although the growth curve was similar (results not shown).

The increase in ATPase activity in the stationary phase is associated with the acidification of the culture medium, observed in inset B of Fig. 1. According to this figure, there is an expressive decrease in the culture $\mathrm{pH}$ during the log phase, reaching values of 4.2 after $10 \mathrm{~h}$ of culture. Consequently, the culture time to obtain membrane fractions rich in ATPase activity was estimated as $12 \mathrm{~h}$.

The procedure used to obtain $S$. mutans membrane fraction resulted in a preparation with specific activity of ATP hydrolysis (120 U/mg) and PNPP (1 U/mg). The optimum pH for ATP hydrolysis for the membrane fraction was around 6.5 , as shown in Fig. 2.

The most efficient detergent used for the solubilization of membrane fraction (Table 1) was SDS, followed by Triton X-114 and sodium cholate (56.0, 34.2 and $32.4 \%$ recovery of the enzyme activity, respectively). As the enzyme was most stable at $4{ }^{\circ} \mathrm{C}$ over 3 days after the solubilization with sodium cholate (data not shown), this detergent was chosen to obtain the solubilized extract.

The optimum pH for ATPase activity obtained for the solubilized extract with sodium cholate, did not show significant variation in relation to that obtained for the membrane fraction (Fig. 2).

The electrophoresis in Fig. 3 shows that sodium cholate solubilized most proteins present in the membrane, since the membrane fraction and solubilized extract profiles are very similar. In this figure (lane 3), we also observed that the $100 \mathrm{kDa}$ band in the sodium cholate solubilized extract is more intense than in the membrane fraction.

The ATPase activity, present in both membrane and solubilized extract, was studied with several inhibitors and the results are shown in Table 2. Orthovanadate, a P-type ATPase inhibitor, was 59 and $82 \%$ efficient for membrane fraction and solubilized extract, respectively. Best inhibition was obtained with lanzoprazole, an $\mathrm{H}^{+}, \mathrm{K}^{+}$-ATPase inhibitor, where $44 \%$ of membrane-bound activity and almost all the activity present in the solubilized extract were inhibited. Oligomycin, an inhibitor of membrane-bound $\mathrm{F}_{1} \mathrm{~F}_{\mathrm{o}}$-ATPase, reduced by 40 and $70 \%$ the ATPase activity present in the membrane fraction and solubilized extract, respectively. DCCD (also an inhibitor of $F_{0}$ subunit of $\mathrm{F}_{1} \mathrm{~F}_{\mathrm{o}}$-ATPase) inhibits about 33 and $7 \%$ the ATPase

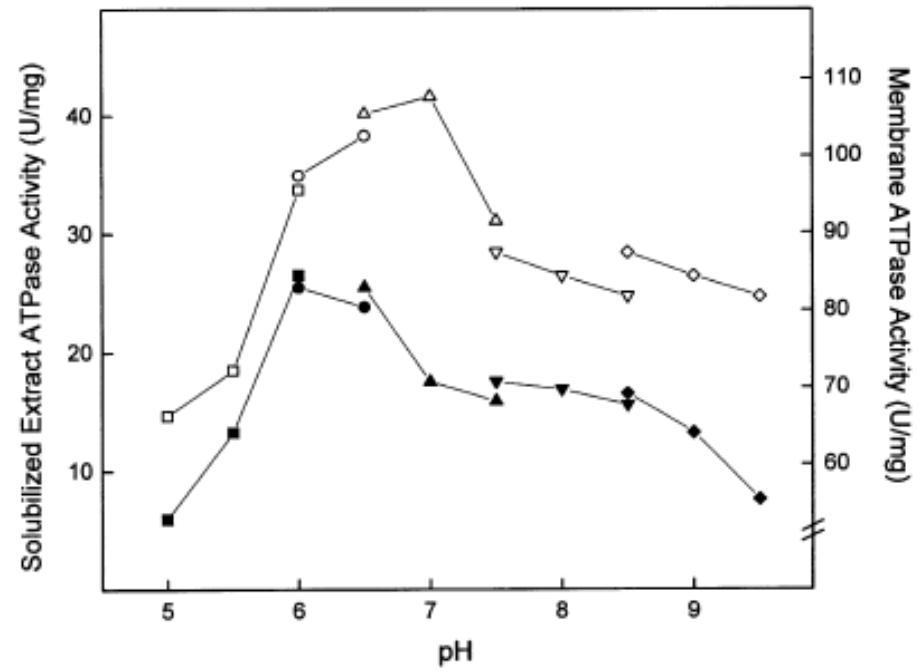

Figure 2 Determination of optimum pH. ATP hydrolysis of S. mutans membrane fraction (open symbols) and solubilized membrane fraction (closed symbols) were assayed in reactional medium containing $5 \mathrm{mM}$ ATP and $5 \mathrm{mM}$ $\mathrm{MgCl}_{2}$, buffered with $50 \mathrm{mM}$ of: $(\boldsymbol{\square}, \square)$ MES (pH 5.0-6.0); $(\bullet, 0)$ Bis-Tris (pH 6.0-6.5); $(\boldsymbol{\Delta}, \triangle)$ imidazol $(\mathrm{pH} 6.5-$ $7.5) ;(\boldsymbol{\nabla}, \nabla)$ Tris $(\mathrm{pH} 7.0-9.0)$; or $(\bullet, \diamond)$ AMPOL $(\mathrm{pH} 8.5-9.5)$. The ATPase activity of $0.1 \mathrm{mg}$ protein was assayed discontinuously at $37^{\circ} \mathrm{C}$ by quantification of phosphate release. Data are reported as the mean of triplicate experiments in which $P<0.05$. 
Table 1 Effect of different detergents on the solubilization of S. mutans membrane fractions.

\begin{tabular}{llll}
\hline Detergent & Concentration $(\mathrm{mg} / \mathrm{ml})$ & Solubilized protein $(\%)$ & ATPase activity $(\%)$ \\
\hline SDS & 10.0 & 24.6 & 56.0 \\
Triton X-114 & 10.0 & 11.0 & 34.2 \\
Sodium cholate & 21.5 & 13.0 & 32.4 \\
Triton X-100 & 10.0 & 13.7 & 24.2 \\
Glucopyranoside & 17.5 & 9.1 & 8.3 \\
CHAPS & 5.0 & 7.9 & 22.4 \\
CHAPSO & 5.0 & 7.7 & 9.1 \\
C $_{12} \mathrm{E}_{8}$ & 1.0 & 7.4 & 13.8 \\
Sodium deoxicholate & 4.0 & 7.2 & 22.4 \\
Tween 20 & 10.0 & 6.4 & 17.4 \\
$\mathrm{C}_{12} \mathrm{E}_{9}$ & 10.0 & 6.3 & 29.3 \\
\hline
\end{tabular}

Membranes $(1.0 \mathrm{mg} / \mathrm{ml})$ were incubated with each detergent for $30 \mathrm{~min}$ at $25^{\circ} \mathrm{C}$, and processed as described in "Materials and methods" section. The ATPase activity was assayed in $50 \mathrm{mM}$ Bis-Tris buffer, pH 6.5, containing $5 \mathrm{mM} \mathrm{MgCl}$ and $5 \mathrm{mM} \mathrm{ATP}$, using $0.1 \mathrm{mg}$ of solubilized protein discontinuously at $37^{\circ} \mathrm{C}$, followed by the quantification of the phosphate released. The specific ATPase activity of $100 \%$ corresponds to $120.0 \mathrm{U} / \mathrm{mg}$. Data are reported as the mean of triplicate experiments in which $P<0.05$.

activity of membrane fraction and solubilized extract, respectively. Sodium azide, another $F_{1} F_{0}$ inhibitor, showed less effectiveness. NEM (protonchannel blocker, and also used as irreversible inhibitor) inhibited around $50 \%$ of the solubilized extract ATPase activity, whereas bafilomycin (V-type ATPase inhibitor) inhibited around $70 \%$ of the activity of both the membrane and solubilized

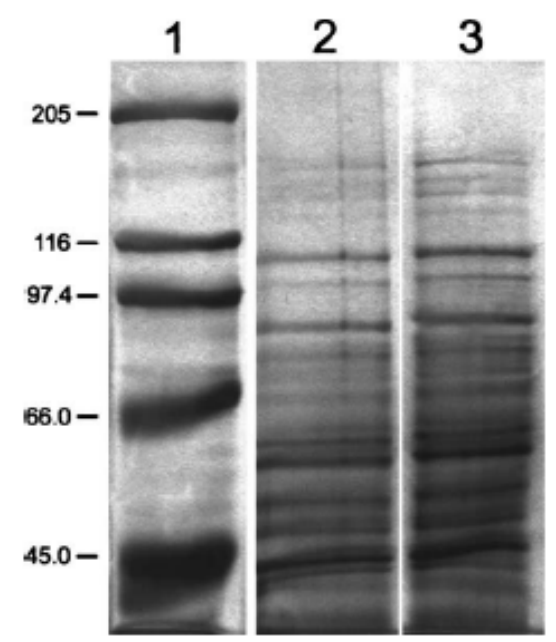

Figure 3 SDS-PAGE: electrophoresis was carried out in $7 \%$ gels according to Laemmli ${ }^{32}$, using silver nitrate for protein staining. (Lane 1) Molecular mass standards; (lane 2) S. mutans membrane fractions; (lane 3) extract solubilized with sodium cholate $50 \mathrm{mM}$ (for details see "Materials and methods"' section).

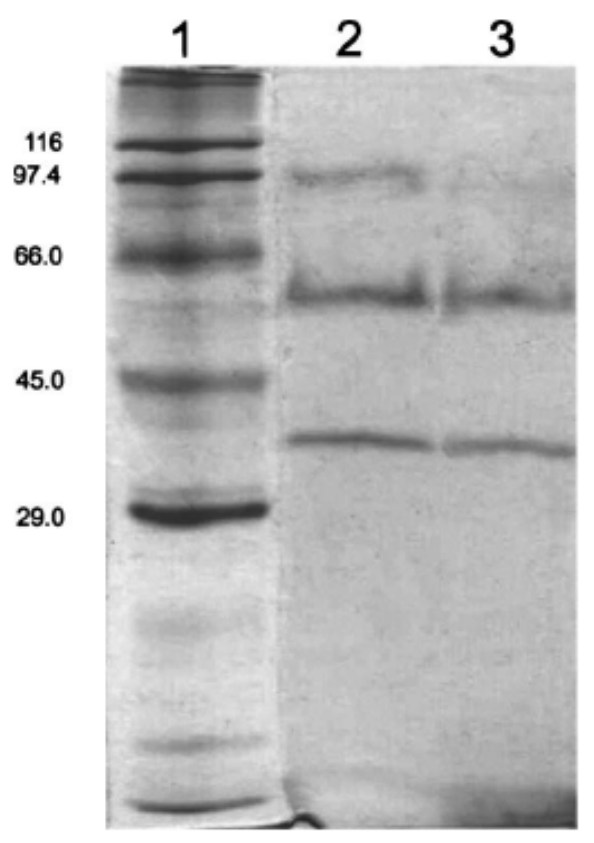

Figure 4 SDS-PAGE: electrophoresis was carried out in $10 \%$ gel according to Laemmli ${ }^{32}$ and renaturated with $50 \mathrm{mM}$ Tris- $\mathrm{HCl}$ buffer, $\mathrm{pH}$ 7.5. The gel was incubated in reaction mixtures of $50 \mathrm{~mm}$ Bis-Tris, $\mathrm{pH} \mathrm{6.5}$, containing $5 \mathrm{mM} \mathrm{MgCl} 2,0.12 \%(\mathrm{w} / \mathrm{v}) \alpha$-naphthyl phosphate, $0.12 \%$ Fast Blue for $24 \mathrm{~h}$, at $25^{\circ} \mathrm{C}$. (Lane 1) Molecular mass standards ( $\mathrm{kDa}$ ) stained with silver nitrate; (lane 2) phosphohydrolytic activity of solubilized extract; (lane 3) phosphohydrolytic activity of solubilized extract in the presence of orthovanadate $3.0 \mu \mathrm{M}$ (for details see "Materials and methods" section). 
Table 2 Effect of different inhibitors over the ATPase activity of S. mutans membrane fraction and solubilized extract.

\begin{tabular}{lccc}
\hline Inhibitor & Concentration & \multicolumn{2}{l}{ Inhibition of ATPase activity (\%) } \\
\cline { 3 - 4 } & & 58.9 & Solubilized extract \\
\hline Orthovanadate & $3.0 \mu \mathrm{M}$ & 44.1 & 82.4 \\
Lanzoprazole & $50 \mu \mathrm{M}$ & 40.4 & 91.2 \\
Oligomycin & $4.0 \mu \mathrm{g} / \mathrm{ml}$ & 32.9 & 70.1 \\
DCCD & $150 \mu \mathrm{M}$ & 13.8 & 7.0 \\
Sodium azide & $0.1 \mathrm{mM}$ & 8.2 & 21.1 \\
NEM & $5.0 \mathrm{mM}$ & 66.9 & 45.0 \\
Bafilomycin & $2.0 \mu \mathrm{M}$ & 10.2 & 78.9 \\
Ouabain & $2.0 \mathrm{mM}$ & 5.6 & 4.4 \\
Thapsigargin & $0.1 \mu \mathrm{M}$ & 39.2 & 28.2 \\
Furosemide & $2.0 \mathrm{mM}$ & 36.7 & 9.7 \\
Ethacrynic acid & $2.0 \mathrm{mM}$ & 28.9 \\
\hline
\end{tabular}

The reactional medium was $50 \mathrm{mM}$ Bis-Tris buffer, $\mathrm{pH} 6.5$, containing $5 \mathrm{mMM} \mathrm{MgCl}$ and $5 \mathrm{mM}$ ATP. The ATPase activity of $0.1 \mathrm{mg}$ protein was assayed discontinuously at $37^{\circ} \mathrm{C}$ by quantification of the phosphate released. The specific ATPase activity of $100 \%$ corresponds to 120.0 and $43.9 \mathrm{U} / \mathrm{mg}$ for $\mathrm{S}$. mutans membrane fraction and solubilized extract, respectively. Data are reported as the mean of triplicate experiments in which $P<0.05$.

${ }^{a}$ Preincubation of inhibitor and enzyme for $1 \mathrm{~h}$, at $4{ }^{\circ} \mathrm{C}$, before kinetic assay.

extract. Finally, ouabain $\left(\mathrm{Na}^{+}, \mathrm{K}^{+}\right.$-ATPase inhibitor), tapsigargin $\left(\mathrm{Ca}^{2+}\right.$-ATPase inhibitor), furosemide, and ethacrynic acid $\left(\mathrm{Na}^{+}\right.$-ATPase or $\mathrm{K}^{+}$ATPase inhibitors) showed little or moderate effect on the membrane-bound or the solubilized extract activities.

ATPase activity present in the membrane fraction was visualized in gels stained for phosphomonohydrolase activity. In this case, three bands of activity were found at 100,55 and $35 \mathrm{kDa}$ (Fig. 4, lane 2). It was observed that only the $100 \mathrm{kDa}$ activity band does not appear in the presence of orthovanadate (Fig. 4, lane 3 ). Similar results were observed in the presence of lanzoprazole (results not shown). SDS-PAGE of the enzyme previously incubated with radioactive [ $\gamma-{ }^{32}$ P]ATP, followed by gel auto radiography, showed only one radioactive band, with molecular weight of around $200 \mathrm{kDa}$ (Fig. 5, lane 1), which was not detected when the assay was made in the presence of orthovanadate (Fig. 5, lane 2).

\section{Discussion}

Suzuki et al. ${ }^{12}$ showed that a mutant strain of $S$. mutans with only $50 \%$ of the total $F_{1} F_{0}$-ATPase activity is able to grow and extrude protons, although with a delay in growth when compared to the wild strain, suggesting the existence of an alternative mechanism for the elimination of intracellular $\mathrm{H}^{+}$produced by the anaerobic metabolism of this organism.
Searching for this alternative $\mathrm{H}^{+}$extrusion pump, we introduced modifications in the procedure described by Bender et al. ${ }^{29}$ which allowed for the isolation of a membrane fraction rich in ATPase activity starting from a lower bacterial mass and with less steps, in which the presence of other ATPases, different from $F_{1} F_{0}$, is supported by inhibitor and kinetic studies.

The Inhibition assay shown in Table 2 confirms that the membrane fraction contains both P-type and F-type ATPase in the proportion of 60 and $40 \%$, respectively. P-type ATPase was inhibited in this proportion ( $60 \%$ of total ATPase activity) by orthovanadate and F-type ATPase was inhibited in complementary proportion by oligomycin and DCCD. ${ }^{34,35}$

The inhibition of membrane fraction by bafilomycin may be related to an unspecific interaction with a putative $\mathrm{H}^{+}$-ATPase, as described for plasma membrane, lysosomal and phagosomal $\mathrm{H}^{+}$-ATPase. ${ }^{36}$

In the solubilized extract, it is difficult to make all comparisons performed for the enzyme present in the membrane, due mainly to non-specific inhibition of the different compounds. However, our present data suggests the presence of about $90 \%$ P-type ATPase in the solubilized extract, suggested by orthovanadate and lanzoprazole effects (see Table 2).

The solubilized extract was inhibited by oligomycin, which supports our contention of the existence of other $\mathrm{H}^{+}$-ATPase in the membrane, since this inhibitor should not affect the solubilized $\mathrm{F}_{1} \mathrm{~F}_{\mathrm{o}^{-}}$ ATPase activity. ${ }^{11}$ This result suggests that the 


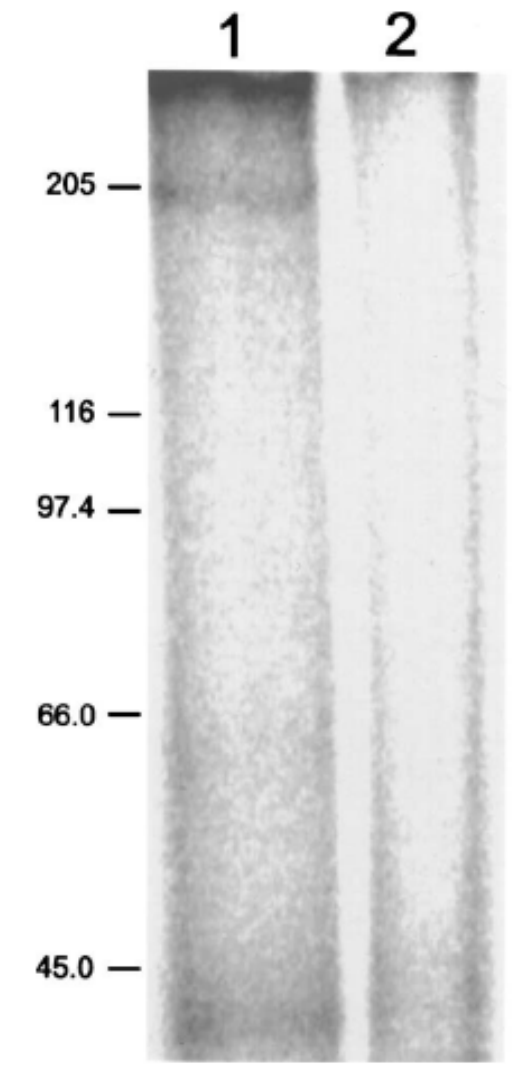

Figure 5 SDS-PAGE: electrophoresis was carried out in $7 \%$ gel according to Laemmli ${ }^{32}$. (Lane 1) Autoradiography of phosphorylated intermediary of ATPase obtained as described in "Materials and methods" section. The phosphorylated image was obtained by autoradiography of dried gels, which was exposed on a storage phosphor screen for 5 days, and subsequently scanned using the STORM 840 Phospholmager (Molecular Dynamics); (lane 2) Autoradiography of phosphorylated ATPase obtained in the presence of $3.0 \mu \mathrm{M}$ orthovanadate in reaction medium (for details see "Materials and methods" section).

putative $\mathrm{H}^{+}$-ATPase described here is a single polypeptide that probably contains a catalytic domain and a transmembrane proton-extrusion channel domain, with one oligomycin-binding site, which is only detected in the solubilized enzyme. The same unspecific effect of bafilomycin ${ }^{36}$ is detected in the solubilized extract.

Indeed, SDS-PAGE of the membrane fraction and cholate solubilized fraction showed one polypeptide of around $100 \mathrm{kDa}$, whose catalytic activity was not seen in the presence of orthovanadate ( $\mathrm{P}$-type ATPase inhibitor) or lanzoprazole $\left(\mathrm{H}^{+}, \mathrm{K}^{+}\right.$-ATPase inhibitor), and can be correlated to a putative $\mathrm{P}$. type $\mathrm{H}^{+}$-ATPase, similar to those described in other organisms like yeast, $N$. crassa and plants. ${ }^{17,18,37}$

We can rule out the possibility of coincidence with the $\mathrm{K}^{+}$-ATPase described by Furst and Solioz ${ }^{27}$ because of the great difference in molecular mass, in spite of vanadate sensibility common to both enzymes. The 55 and $35 \mathrm{kDa}$ bands with catalytic activity (Fig. 4, lane 2), may represent another phos phomonohydrolase present in the plasma membrane, since the catalytic activity of the isolated $55 \mathrm{kDa} \beta$ subunit of $\mathrm{F}_{1} \mathrm{~F}_{\mathrm{o}}$-ATPase is very small, or does not exist. ${ }^{38,39}$

Radioactive markers are tools widely used for study of P-type ATPases, since all enzymes of this class form a $\beta$-aspartil phosphate phosphorylated intermediate in their catalytic cycle. ${ }^{17,18,40}$ In fact, one band for the phosphoenzyme has been detected, which disappears when the assay is done in the presence of orthovanadate or lanzoprazole (Fig. 5), supporting the existence of a P-type ATPase. ${ }^{17,18}$ The molecular weight corresponding to the phosphoenzyme was two-fold (around $200 \mathrm{kDa}$ ) in comparison with the band that was detected for phosphomonohydrolase activity, suggesting a possible strong aggregation or dimerization in the phosphoenzyme state. Also, the $\mathrm{Ca}^{2+}$. ATPase family present a common capacity to form strongly bound dimers, tetramers and even hexamers, depending upon the conditions of the moiety. It is, therefore, not surprising to find a mass for the phosphoenzyme that corresponds to the dimeric form. Besides, glycosylated proteins and/or those with highly hydrophobic domains have a high tendency to aggregate, even in the presence of SDS. ${ }^{41-43}$

This aggregation behaviour has been recently described for plant $\mathrm{H}^{+}$-ATPase and $N$. crassa $\mathrm{H}^{+}$. ATPase, resulting in a phosphorylated band at $230 \mathrm{kDa}$, also suggesting the dimerization of this enzyme. ${ }^{17}$

Finally, the values found for optimum $\mathrm{pH}$ for the membrane fraction and solubilized extract ATPase activity were around 6.5. Values of optimum pH around 6 were found for $N$. crassa and S. cerevisae plasma membrane P-type $\mathrm{H}^{+}$-ATPase, ${ }^{4,45}$ and bacterial $F_{1} F_{0}$-ATPase. ${ }^{29}$

Possibly, putative $\mathrm{H}^{+}$-ATPase or $\mathrm{H}^{+}$, ion-antiport ATPase activity described here was detected due to the modifications introduced in the procedure described by Bender et al. ${ }^{29} \mathrm{Also}$, this act ivity seems to be subject to induction, since a large increase in activity is detected after lowering the $\mathrm{pH}$ culture medium to about 4.0 (Fig. 1, inset A). This confirms that $S$. mutans can adapt to an acid environment by an increase in ATPase activity levels, which remove protons from the cytoplasm and also protect relatively acid-sensitive glycolytic enzymes. ${ }^{4,5}$ 
Moreover, exploring the recently published genome sequence of S. mutans UA159, ${ }^{46}$ we have identified a putative P-type ATPase (24379191 putative calcium transport P-type ATPase) which shows high homology to $\mathrm{H}^{+}$-ATPase of $N$. crassa (Blast results: score $=222$ bits (566) Expect 3e-56). This possibility provides more convincing evidence that the proposed $\mathrm{H}^{+}$-ATPase or $\mathrm{H}^{+}$,ion-antiport ATPase could exist working in association with $F_{1} F_{0}$-ATPase, extruding $\mathrm{H}^{+}$during the growth of these bacteria. In addition to that, it should be stressed that there is a calcium-ATPase involved in the exchange of one $\mathrm{H}^{+}$per $\mathrm{Ca}^{2+}$ similar to $\mathrm{Na}, \mathrm{K}$ or $\mathrm{H}, \mathrm{K}$-ATPase. ${ }^{47}$

In S. faecalis, a $\mathrm{H}^{+}, \mathrm{Ca}^{2+}$-ATPase was described but denoted as ATP-linked calcium transport. ${ }^{48}$ This protein was studied only in membrane vesicles prepared from $S$. faecalis membrane fractions and kinetic characterization was not done.

The data presented here describe a protein with molecular weight of $100 \mathrm{kDa}$, which presents ATPase activity inhibited by classic inhibitors of P-type and $\mathrm{H}^{+}, \mathrm{K}^{+}$-ATPases, has optimum $\mathrm{pH}$ comparable to other $\mathrm{H}^{+}$-ATPases and undergoes phosphorylation during the catalytic reaction, like the $\mathrm{H}^{+}$-ATPases described in yeast and plant plasma membrane. ${ }^{17,18,37}$

Together, these results strongly suggest that the enzyme enriched by the present methodology is a Ptype $\mathrm{H}^{+}$-ATPase or $\mathrm{H}^{+}$, ion-antiport ATPase that can act in association with $\mathrm{F}_{1} \mathrm{~F}_{\mathrm{o}}$-ATPase during growth of S. mutans in low $\mathrm{pH}$ environments.

\section{Acknowledgements}

We thank Priscila Cerviglieri for revision of the manuscript. We also thank FAPESP and CNPq for the continuous support given to our laboratories. PPM and TPP are the recipient of a Ph.D. fellowship from CAPES.

\section{References}

1. Mikkelsen L, Jensen SB, Jakobsen J. Microbial studies on plaque from carious and caries-free proximal tooth surfaces in a population with high caries experience. Caries Res 1981;15:428-35.

2. Chestnutt IG, Macfartane TW, Stephen KW. An in vitro investigation of the cariogenic potential of oral streptococci. Arch Oral Biol 1994; 7:589-93.

3. Heefner DL. Transport of $\mathrm{H}^{+}, \mathrm{K}^{+}, \mathrm{Na}^{+}$and $\mathrm{Ca}^{2+}$ in Streptococcus. Mol Cell Eiochem 1982;44:81-106.

4. Belli WA, Marquis RE. Adaptation of Streptococaus mutans and Enterococcus hirae to acid stress in continuous culture. Appl Environ Microbiol 1991;57:1134-8.

5. Hamilton IR, Buckley ND. Adaptation by Streptococcus mutans to acid tolerance. Oral Microbiol immunol 1991; 6:65-7.
6. Köhler B, Birkhead D, Olssom S. Acid production by human strains of Streptococous mutans and Streptococas sobrinus. Caries Res 1995;29:402-6.

7. Takahashi $N$, Horiuchi $M$, Yamada T. Effects of acidification on growth and glycolysis of Streptococous sanguis and Streptococcus mutans. Oral Microbiol immunol 1997;12: 72-6.

8. Quivey Jr RG, Kuhnert WL, Hahn K. Adaptation of oral streptococci to low pH. Adv Mikrob Physiol 2000;42:239-74.

9. Schnebli HP, Abrams A. Membrane adenos ine triphosphatase from Streptococcus foecalis: preparation and homogeneity. $J$ Biol Chem 1970;245:1115-21.

10. Smith AJ, Quivey RG, Faustoferri RC. Cloning and nucleotide sequence analysis of the Streptococcus mutans membranebound, proton-translocating ATPase operon. Gene 1996;183: 87-96.

11. Curti C, Uyemura SA. A simple student project to isolate subcellular fractions and analyse membrane-bound and Triton X-100 solubilized enzyme activity. Biochem Educ 1989:17:213-4.

12. Suzuki T, Tagami J, Hanada N. Role of $\mathrm{F}_{1} \mathrm{~F}_{0}-A$ TPase in the growth of Streptococcus mutans GS5. J Appl Microbiol 2000; 88:555-62.

13. Andersen JP, Vilsen B. Primary ion pumps. Curr Opin Cell Biol 1990;2:722-30.

14. Carafoli $\mathrm{E}$. Calcium pump of the plasma membrane. Physiol Rev 1991;71:129-53.

15. Inesi G, Kirtley MR. Structural features of cation transport ATPases. J Bioeners Biomembr 1992;24:321-44.

16. Vigneron L, Scarborough GA, Ruysschaert JM, Goormaghtigh E. Reconstitution of the Neurospora crassa plasma membrane $\mathrm{H}^{+}$-adenosine triphosphatase. Eiochim Biaphys Acta $1995 ; 1236: 95-104$.

17. Morsomme $P$, Boutry $M$. The plant plasma membrane $\mathrm{H}^{+}$. ATPase: structure, function and regulation. Biochim Biophys Acta 2000;1465:1-6.

18. Ambesi A, Miranda $M$, Petrov $\mathrm{VV}$, Slayman $\mathrm{CW}$. Biogenesis and function of the yeast plasma-membrane $\mathrm{H}^{+}$-ATPase. $J$ Exp Biol 2000;203:155-60.

19. Skou JC, Esmann M. The $\left(\mathrm{Na}^{+}, \mathrm{K}^{+}\right)$-ATPase. I Bioenerg Eiomembr 1992;24:249-61.

20. Pressley TA. Structure and function of the Na,K pump: ten years of molecular biology. Miner Electrolyte Metab 1996;22: 264-71.

21. Lingrel JB, Arguello JM, VanHuysse J, Kuntzweiler TA. Cation and cardiac glycosid binding sites of the $\mathrm{Na}, \mathrm{K}$ ATPase. Ann N Y Acad Sci USA 1997;834:194-206.

22. Lingrel JB, Croyle LM, Woo AL, Arguello JM. Ligand binding sites of Na,K-ATPase. Acta Physiol Scand 1998;163:69-77.

23. Jorgensen PL, Nielsen JM, Rasmussen JH, Pedersen PA. Structure-function relationships of E1-E2 transitions and cation binding in Na,K-pump protein. Biochim Biophys Acta 1998:1365:65-70.

24. Wach A, Schlesser A, Goffeau A. An alignment of 17 deduced protein sequences from plant, fungi, and ciliate $\mathrm{H}^{+}$-ATPase genes. $J$ Bicenerg Biomembr 1992;24:309-17.

25. Moller JV, Juul B, le Maire M. Structural organization, ion transport, and transduction of P-type ATPases. Biochim Biophys Acta 1996;1286:1-51.

26. Hoskins J, Alborn WE, Arnold J. Genome of the bacterium Streptococcus pneumoniae strain R6. J Bacteriol 2001;183: 5709-17.

27. Furst $P$, Solioz M. The vanadate-sensitive ATPase of Streptococcus foecalis pumps potassium in a reconstituted system. $J$ Biol Chem 1986;261:4302-8.

28. Harper DS, Loesche WS. Growth and acid tolerance of human dental plaque bacteria. Arch Oral Biol 1984;10:843-8. 
29. Bender GR, Sutton SWW, Marquis RE. Acid tolerance, proton permeabilities, and membrane ATPases of oral streptococ. ci. infect immun 1986;53:331-8.

30. Hartree EF. Determination of proteins: a modification of the Lowry method that gives a linear photometric response. Anal Biochem 1972;48:422-7.

31. Heinonen SK, Lathi RJ. A new and convenient colorimetric detemination of inorganic orthophosphate and its application to the assay of inorganic pyrophosphatase. Anal Eiochem 1981;113:313-7.

32. Laemmli UK. Cleavage of structural proteins during the assembly of the head bacteriophage T4. Nature 1970;227: 680-5.

33. Blum H, Beir $\mathrm{H}$, Gross HJ. Improved silver stainung of plant proteins, RNA and DNA in polyacrilamide gels. Electrophares is 1987;8:93-9.

34. Fedosova NU, Cornelius F, Klodos I. E2P phosphoforms of Na, K-ATPase. I. Comparison of phosphointermediates formed from ATP and $\mathrm{Pi}$ by their reactivity toward hydroxylamine and vanadate. Biochemistry 1998;37: $13634-42$.

35. Barradel LB, Fauds D, Mctavish D. Lanzoprazole. A review of its pharmacodynamic and pharmacokinetic proprieties and its therapeutic efficacy in acid-related disorders. Drugs 1992; 44:225-50.

36. Tapper $H$, Sundler R. Bafilomycin $A_{1}$ inhibits tysosomal, phagosomal, and plasma membrane $\mathrm{H}^{+}$-ATPase and induces lysosomal enzyme secretion in macrophages. J Cell Physiol 1995; 163:137-44.

37. Scarborough GA. The plasma membrane proton-translocating ATPase. Cell Mol Life Sci 2000;57:871-83.

38. Weber J, Sênior AE. Catalytic mechanism of $F_{1}-A T P a s e$. Biochim Biophys Acta 1997;1319:19-58.
39. Gromet-Elhanan Z. Identification of subunits required for the catalytic activity of the $\mathrm{F}_{1}$-ATPase. J Bioenerg Biomembr 1992;24:447-52.

40. Smith HE, Hammes GG. Studies of the phosphoenzyme intermediate of the yeast plasma membrane protontranslocating ATPase. J Biol Chem 1988;263:13774-8.

41. Sagné C, Isambert MF, Henry JP, Gasnier B. SDS-resistant aggregation of membrane proteins: application to the purification of the vesicular monoamine tranansporter. Biochem J 1996;316:825-31.

42. Chadwick CC, Goormaghtigh E, Scarborough GA. A hexameric form of the Neurospara crassa plasma membrane $\mathrm{H}^{+}$. ATPase. Arch Biochem Biophys 1987;252:348-56.

43. Goormaghtigh E, Chadwick C, Scarborough GA. Monomers of the Neurospora plasma membrane $\mathrm{H}^{+}$-ATPase catalyze efficient proton translocation. I Biol Chem 1986;261: 7466-71.

44. Brooker RJ, Slayman CW. Inhibition of the plasma mem brane $\left[\mathrm{H}^{+}\right]$-ATPase of Neurospara crassa by $\mathrm{N}$-ethylmalei mide. J Biol Chem 1982;257:12051-5.

45. Bowmam BJ, Bowman EJ. $\mathrm{H}^{+}$-ATPases from mitochondria, plasma membranes, and vacuoles of fungal cells. $J$ Membr Chem 1986;94:83-97.

46. Ajdic D, McShan WM, McLaughlin RE, Savic G, Chang J, Carson MB, et al. Genome sequence of Streptococcus mutans UA159, a cariogenic dental pathogen. Proc Natl Acad Sci USA 2002;99:14434-9.

47. MacLennan DH, Rice WJ, Green NM. The mechanism of $\mathrm{Ca}^{2+}$ transport by sarco(endo)plasmic reticulum $\mathrm{Ca}^{2+}$-ATPases. $J$ Biol Chem 1997;272:28815-8.

48. Kobayashi $\mathrm{H}$, Van Brant J, Harold FM. ATP-linked calcium transport in cells membrane vesicles of Streptococous foecalis. J Biol Chem 1978;253:2085-92. 


\title{
Laboratory Exercises
}

\section{Fermentable and Non-fermentable Sugars}

\author{
A SIMPLE EXPERIMENT OF ANAEROBIC METABOLISM*
}

Received for publication, October 11, 2002, and in revised form, December 23, 2002

\begin{abstract}
Tony P. Paulinoł§, Mauro Cardoso, Jr.ף, Giuliana C. M. Bruschi-Thedeiף, Pietro Ciancaglinił, and Geraldo Thedei, Jr. T\|

From the $\ddagger$ Departamento de Quimica, Faculdade de Filosofia, Ciencias e Letras de Ribeirăo Preto, Universidade de Săo Paulo, 14040-901 Ribeiráo Preto, SP, Brazil and the Ilinstituto de Ciências Biológicas e da Saúde, Universidade de Uberaba, 38055-500 Uberaba, MG, Brazil
\end{abstract}

\begin{abstract}
The main objective of this class experiment is to show the time-dependent consumption of a fermentable sugar (glucose) in the presence and absence of a non-fermentable sugar (xylose) by bacteria in anaerobic conditions. The observation of the $\mathrm{pH}$ decrease due to acid production and the turbidity increase as a result of cell multiplication, both in function of time, enables an interesting discussion regarding the metabolic pathways and the products of anaerobic fermentation of carbohydrates. Also the time-dependent disappearance of glucose due to its metabolic consumption is compared with the non-disappearance of xylose and permits a discussion of the function of glycolysis and pentose phosphate pathways as metabolic routes.
\end{abstract}

Keywords: Streptococcus mutans, glucose, xylose, metabolism, thin layer chromatography.

The diverse fuels available in nature are metabolized by different organisms in different ways. For instance, glucose may be utilized aerobically, in which case this carbohydrate is transformed in $\mathrm{CO}_{2}$ and water giving a high energetic yield. Alternatively in anaerobic use the oxidation is incomplete, and the energetic yield is considerably lower. In the case of anaerobic use, by-products are released, and many of these by-products are of great commercial importance, such as ethanol (present in fuel and alcoholic beverages) and lactic/acetic acid (for industrial and domestic use) among others.

Class experiments for an introductory biochemistry course, which aims to demonstrate the metabolic diversity present in different organisms, require both the choice of an adequate biological model and the knowledge of its advantageous features and limitations. The bacteria Streptococcus mutans is present in the oral cavity and is one of the main organisms responsible for causing cavities. $S$. mutans is fast growing in a low cost and easy prepared culture medium, has a metabolic versatility reflected by the utilization of different carbon sources, and finally is readily studied biochemically [1]. S. mutans is an aerotolerant bacterium that does not have a respiratory chain and produces ATP by anaerobic glycolysis. In contrast to the aerobic organisms, the $F_{0} F_{1}$-ATPase in $S$. mutans is a

- This work was supported by the Universidade de Uberaba Fundaçao de Amparo à Pesquisa do Estado de São Paulo, and Conselho Nacional de Pesquisas (Brazil).

§ Recipient of a Ph.D. fellowship from the Comissao de Aperfeiçoamento de Pessoal de Nival Superior.

|| To whom correspondence should be addressed. E-mail: geraldo.thedei@uniube.br. proton-extruding enzyme and not an ATP synthesizer by $\mathrm{H}^{+}$influx $[2,3]$.

The main objective of this experiment is to discuss the anaerobic utilization of glucose by S. mutans in a medium either supplemented exclusively with this sugar or mixed with a non-fermentable carbohydrate as well as the consequential acid production under these cultivation conditions.

BACKGROUND THEORY AND PRE-LABORATORY PREPARATION

D-Glucose is the major fuel of most organisms and occupies a central position in metabolism. Moreover it is also a remarkably versatile precursor capable of supplying a wide array of metabolic intermediates for biosynthetic reactions. A bacterium such as Escherichia coli can use glucose to obtain the carbon skeletons for every amino acid, nucleotide, co-enzyme, fatty acid, or other metabolic intermediate needed for growth. In a general way, glucose has three major fates.

1. It may be stored (as a polysaccharides or as sucrose),

2. oxidized to a three-carbon compound (pyruvate) via glycolysis, or

3. oxidized to pentoses via the pentose phosphate (phosphogluconate) pathway.

In glycolysis, a molecule of glucose is degraded in a series of enzyme-catalyzed reactions to yield two molecules of the three-carbon compound pyruvate. During the sequential reactions of glycolysis in the presence of oxygen, some of the free energy released from glucose is converted to ATP and NADH. For an integrated vision of 
aerobic glucose metabolism and of mitochondrial ATP formation, see Hanson [4] or Nicholson [5], respectively.

In anaerobic fermentation, glucose or other organic nutrients are degraded to obtain energy, which is conserved as ATP and occurs without the net production of NADH. Because living organisms first arose in an atmosphere without oxygen, anaerobic breakdown of glucose is probably the most ancient biological mechanism for obtaining energy from organic fuel molecules. In the course of evolution, the chemistry of this reaction sequence has been completely maintained, and both the amino acid sequence and three-dimensional structures of the glycolytic enzymes of vertebrates are closely similar. Glycolysis differs among species only in the details of its regulation and the subsequent metabolic fate of the pyruvate formed. Depending on the organism, lactate or ethanol can be formed anaerobically [6].

Other pathways, like the pentose phophate pathway (PPP), ${ }^{1}$ are also involved in the carbohydrate utilization. The PPP has two phases, called oxidative and non-oxidative, involved in supplying ribose for nucleic acid synthesis and in reducing potential (NADPH) for biosynthetic reactions, respectively. For more details, it is recommended that the student reads biochemistry textbooks $[3,6]$.

The simple experiment proposed here permits the discussion of essential aspects of anaerobic glucose metabolism and microbial growth. To profit from this practice, the students should know the basics of these topics.

\section{GENERAL NOTES}

In this class experiment, we describe a methodology adapted to the use of $S$. mutans, which can be acquired commercially. There is the possibility of isolating a lineage of $S$. mutans by inoculating a saliva sample in the selective culture medium MSBS (Mitis Salivarius Bacitracin Sucrose) [7]. Alternatively other acid-forming microorganisms could be used as well as other variations in the culture medium with the substitution of glucose by other sugars such as maltose or sucrose. Agents that inhibit specific enzymes of the glycolytic way, such as fluoride, can be added to the medium (5 $\mu \mathrm{m}$ final concentration), allowing the visualization of a delay and compromising the S. mutans growth.

Generally this class experiment uses some hazardous reagents such as sulfuric acid, methanol, and pyridine. These reagents should be manipulated with gloves and care in a fume cupboard. Their disposal should be made in accordance with local safety instructions.

\section{EXPERIMENTAL PROCEDURES}

Strain - The ATCC 25175 strain of S. mutans is available from the André Tosello Foundation, Campinas-SP (Brazil) (www.bdt.fat.org.br/). The lineage is stored at $-20^{\circ} \mathrm{C}$ in $40 \%$ (v/v) glycerol.

Liquid Medium-The liquid medium used to cultivate the S. mutans strains was tryptic soy broth (TSB), prepared according to the manufacturer's instructions, which results in $13 \mathrm{~mm}$ dextrose, $17 \mathrm{~g} /$ liter pancreatic digest of casein, $3 \mathrm{~g} /$ iter papain digest of soybean meal, $5 \mathrm{~g} / \mathrm{liter} \mathrm{NaCl}, 2.5 \mathrm{~g} /$ liter $\mathrm{K}_{2} \mathrm{HPO}_{4}$. The medium $(4 \mathrm{ml})$ was distributed in $15-\mathrm{ml}$ Falcon tubes, which were auto-

${ }^{1}$ The abbreviations used are: PPP, pentose phophate pathway; TSB, tryptic soy broth; TLC, thin layer chromatography. claved at $121^{\circ} \mathrm{C}$ for $15 \mathrm{~min}$. For the growth test in the presence of xylose as the only carbon source and for the tests without carbon source, the complete medium described by Dhasper and Reynolds [8] was used.

Anaerobic Growth Conditions-All the cultivations were done in a candle jar in an anaerobic atmosphere obtained after lighting a candle inside the jar to consume part of the oxygen. A preinoculate was prepared by inoculating $50 \mu \mathrm{l}$ of the $S$. mutans stock in $4 \mathrm{ml}$ of TSB medium at $37^{\circ} \mathrm{C}$ for $24 \mathrm{~h}$. The stock was submitted to three successive transferences in TSB medium (12-h incubation) to reestablish their normal metabolism; this will be called the pre-inoculate. For growth assays, the initial turbidity of the pre-inoculate was adjusted to $A_{\text {ooo mm }}=0.5$, corresponding to $\sim 10^{\ominus}$ cells $/ \mathrm{ml}$ (for details see Ref. 9 ). Tubes containing $4 \mathrm{ml}$ of previously autoclaved TSB medium were inoculated with $15 \mu \mathrm{l}$ of this cell suspension. Cultures were grown in a microbiological oven and incubated in microaerobiosis (as cited above) at $37^{\circ} \mathrm{C}$. For each point of the curve (2-h intervals), two tubes were collected to measure the $\mathrm{pH}$ and turbidity of the culture medium. After this, the media were centrifuged at $3,000 \times g$ for 10 min to obtain a medium free of cells, which was used in glucose dosage tests and sugar quantitative analysis by silica plate chromatography (thin layer chromatography (TLC)).

In another growth assay, $26 \mu$ l of xylose $(2 \mathrm{M})$ was added to each tube containing culture medium (TSB or complete medium) to obtain a final concentration of $13 \mathrm{~mm}$. This assay was submitted to the same conditions and tests as described above.

Xylose Solution-The stock xylose solution, used to complement the TSB culture medium or the complete medium, was prepared at a final concentration of $2 \mathrm{M}$ and autoclaved at $121^{\circ} \mathrm{C}$ for $15 \mathrm{~min}$.

TLC-The silica plate for TLC (Sigma, $20 \times 20 \mathrm{~cm}$ ) was activated at $100^{\circ} \mathrm{C}$ for $2 \mathrm{~h}$ before use. $0.5 \mathrm{ml}$ of $30 \%$ (w/v) trichloroacetic acid was added to aliquots $(1 \mathrm{ml})$ of the growing medium free of cells, and after mixing with a Vortex for 1 min the aliquots were kept ovemight at $4^{\circ} \mathrm{C}$. Samples were centrifuged at $3,000 \times$ $g$ for $15 \mathrm{~min}$, and $50 \mu \mathrm{l}$ of the supernatant was vacuum-concentrated (10-fold) and applied to the TLC plate. As standards, $3 \mu$ l of glucose, xylose $(50 \mathrm{mg} / \mathrm{ml})$, or a mixture of these sugar solutions (25 mg/ml of each) were applied. The mobile phase was composed of $n$-butyl alcohol:pyridine:water:methanol in a 7:3:1:0.45 proportion (by volume). After chromatography, the plate was dried at room temperature in the fume cupboard and then sprayed with a solution containing $0.2 \%(\mathrm{w} / \mathrm{v})$ orcinol in sulfuric $\mathrm{acid} / \mathrm{methanol}(\mathrm{v} / \mathrm{v})$ and revealed in a oven at $150^{\circ} \mathrm{C}$ for $5-10 \mathrm{~min}$. For details about the TLC method, see Ref. 10.

Glucose Assays-For the glucose dosage, a commercially available kit was used (Glucox 500 , Doles Reagentes) that uses the enzymes glucose oxidase and peroxidase in the presence of 4 -aminoantipyrine and $p$-hydroxybenzoate. This reaction is based on the oxidation of the glucose molecule with the consequent production of a compound (quinoneimine) that is then spectrophotometrically quantified using Lambert-Beer's law [11] Alternatively other glucose dosage kits (e.g. Sigma) can be used since they use the same dosage principle. A standard curve was built with increasing quantities of glucose $(0.05-0.5 \mathrm{mg} / \mathrm{ml})$ and used to determine a conversion factor (absorbance at $510 \mathrm{~nm} / \mu \mathrm{g}$ of glucose). The presence of xylose does not affect the glucose determination by this method.

Cell Disposa/-The cells that were not used or remained from the experiment were autoclaved at $121^{\circ} \mathrm{C}$ for $20 \mathrm{~min}$ and then discarded.

\section{STUDENT PITFALLS}

This is a very easy class experiment, but some problems such as culture contamination may occur as a result of bad manipulation. Some doubts can arise in calculating the conversion factor. The conversion factor is calculated by linear regression of the standard curve and corresponds to 
182

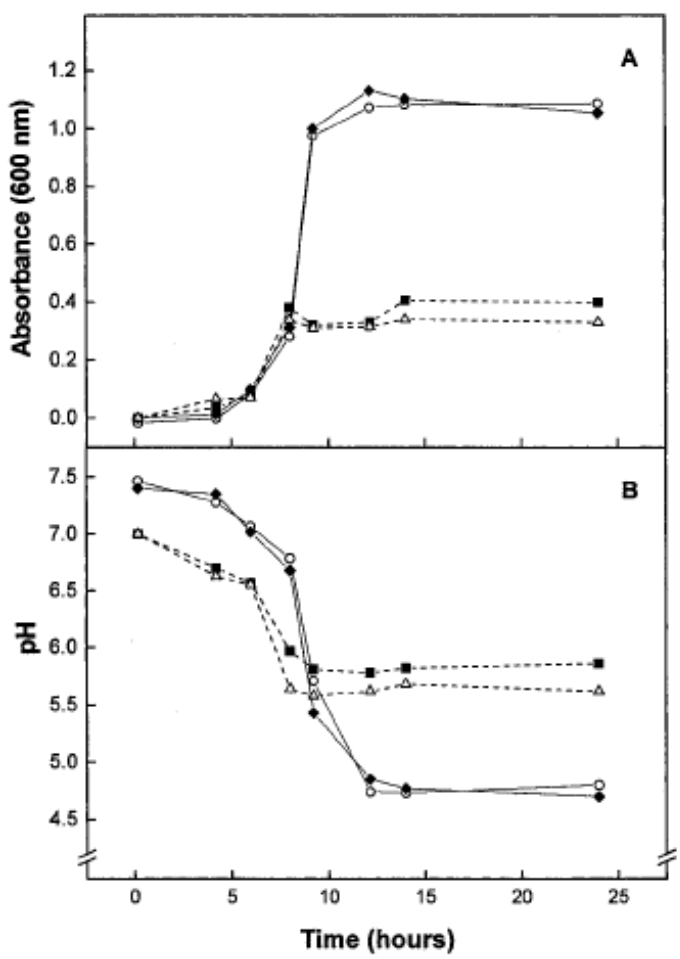

FIG. 1. Growth curves of $S$. mutans showing the absorbance at $600 \mathrm{~nm}(A)$ and $\mathrm{pH}(\mathrm{B})$ variation as a function of cultivation time in TSB medium (-) or complete medium (- .- -) without carbon source $(\Delta)$, with $13 \mathrm{~mm}$ glucose $(O)$, with $13 \mathrm{~mm}$ xylose (E), or with $13 \mathrm{~mm}$ glucose plus $13 \mathrm{~mm}$ xylose $(\Delta)$. Each point is the mean of three experiments. For details of the assay, see "Experimental Procedures.

its angular coefficient. An absorbance value multiplied by this factor gives the glucose concentration present in the tube, which should be used to calculate the amount of glucose present in the growth medium.

\section{RESULTS AND DISCUSSION}

S. mutans is a bacterium normally present in the buccal microbiota, and its relation to the appearance of caries is evident. This relation is due to its high growth capacity and production of organic acids such as lactic, propionic, and acetic [1]

Fig. $1 A$ shows a growing curve of $S$. mutans in media without carbon source and with glucose-, xylose-, and glucose plus xylose-supplemented media in anaerobic conditions. In the first 5 growing $\mathrm{h}$ (lag phase), the cellular multiplication, as measured by $A_{600 \mathrm{~nm}}$, is very low. In this phase, the cells adapt to the culture medium (with respect to the possible nutrients present) and prepare an enzymatic apparatus for the next step of the culture growth. In media supplemented with glucose or with a mixture of glucose plus xylose, the microorganism reproduces itself in exponential scale over the following $7 \mathrm{~h}$, and the turbid-
BAMBED, Vol. 31, No. 3, pp. 180-184, 2003

ity of the medium increases in a logarithmic form (log phase). Finally, after $12 \mathrm{~h}$ of cultivation, a phase with no substantial growth will start (stationary phase) due to nutrient depletion and/or to the accumulation of toxic metabolites, which may be the final products of the anaerobic cellular metabolism, such as organic acids. The addition of xylose to the culture medium containing glucose did not affect the growth kinetics as shown in Fig. $1 A$.

In media in which the only carbon source is xylose, a small increase in turbidity $2 \mathrm{~h}$ after the lag phase is observed that soon stabilizes and leads to a stationary phase (Fig. $1 A$ ). This suggests that $S$. mutans does not metabolize xylose because a similar growth curve is obtained when the cultivation is done in a medium with no carbon source. The limited growth in these two conditions shows that the microorganism has intracellular energy reserves, possibly in the form of polysaccharides, as previously described [12]. These reserves would be enough to start growth, but they would soon be depleted.

In Fig. $1 B$ it may be observed that the most significant $\mathrm{pH}$ decrease of the culture media occurs during the log phase of the culture media supplemented with glucose or with the mixture of glucose and xylose. Nevertheless, in the media without a carbon source or supplemented only with xylose, the decrease is less significant. In all cases, the $\mathrm{pH}$ decrease is mainly due to lactic acid production as a result of the anaerobic metabolism of the glucose by S. mutans [9]. As in media without the addition of carbohydrate or supplemented only with xylose the fermentable quantity of sugar is small (restricted to the intracellular reserves), and the acidification is significantly smaller. Acid production in vivo by bacteria adhering to the dental surface induces the demineralization of the tooth enamel and consequently the appearance of cavities $[13,14]$.

The amount of glucose present in the culture media was monitored during the growth period, and in Fig. 2 it is observed that during the time between the log phase (5-12 h) there is a sharp decrease in the amount of this sugar, which reaches minimum values at the beginning of the stationary phase $(12 \mathrm{~h})$ and is one of the factors that contributes to ending growth in this phase. The high consumption of glucose during the log phase clearly demonstrates the active metabolism of the bacterium, which is directed toward cellular activity maintenance such as active transport and cellular multiplication (Fig. $1 A$ ) and which also explains the high production of acid (Fig. 1B) during this phase. These observations are confirmed by TLC analysis of the culture media after different growth times (Fig. 3 ). The glucose is gradually consumed and disappears at the end of the log phase (lanes 1-4), while the xylose is detected during the whole period studied (lanes 5-8). Note that the mixture of glucose and xylose affects the migration of both carbohydrates (lanes 9-11). Thus, the progressive attenuation of spots 5-8 reflects the consumption of glucose, whereas the levels of xylose remain constant.

The lack of xylose consumption is interesting because this pentose could in principle be used through the PPP, whose major function is the production of reducing potential (NADPH) and the interconversion of sugars with carbon numbers between 3 and 7 [6]. However, S. mutans does not have the oxidative enzymes of the PPP and apparently 


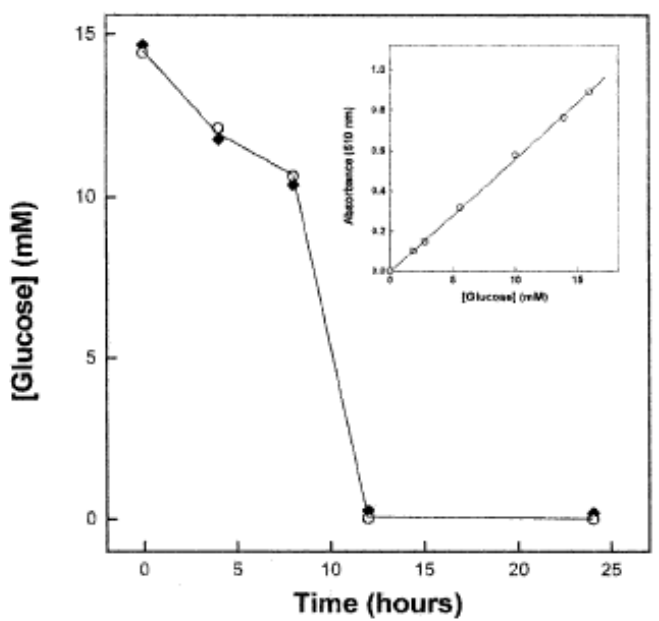

FiG. 2. Glucose concentration as a function of $S$. mutans growth time in TSB medium supplemented $(\boldsymbol{\Lambda})$ or not $(\mathrm{O})$ with $13 \mathrm{~mm}$ xylose. Inset, standard calibration curve using the glucose assay kit. Each point is the mean of three experiments. For details of the assay, see "Experimental Procedures."

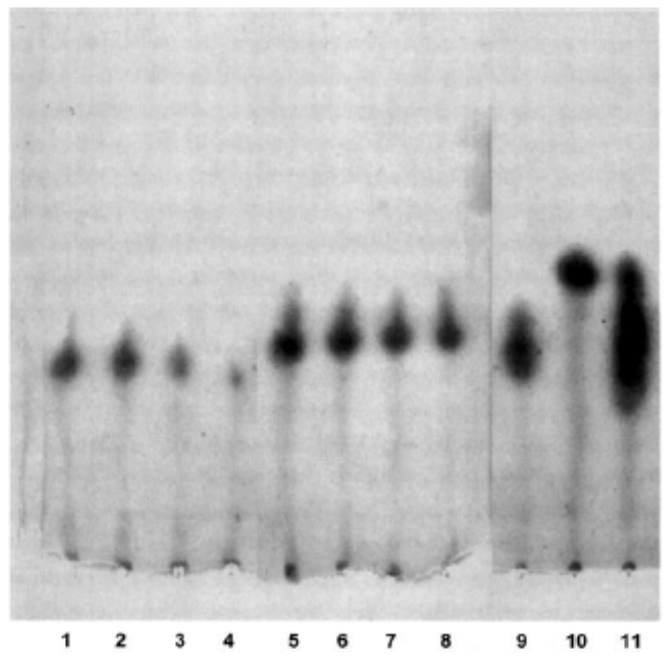

FIG. 3. TLC of reference carbohydrate and culture medium of S. mutans after growth in medium supplemented with $13 \mathrm{~mm}$ glucose (lanes 1-4) for $4,8,12$, and $24 \mathrm{~h}$, respectively, or with 13 mм glucose plus $13 \mathrm{~mm}$ xylose (lanes $5-8$ ) for $4,8,12$, and $24 \mathrm{~h}$, respectively. Lanes 9,10 , and 11 contain glucose, xylose, and glucose plus xylose mixture standards, respectively. For details, see "Experimental Procedures."

uses ribose to supply carbon atoms for amino acid biosynthesis [15]. The lack of significant growth in the presence of xylose (Fig. 1) suggests that $S$. mutans is unable to transport this sugar inside the cell and/or convert this sugar in some PPP intermediate.

In conclusion, this class experiment shows that the anaerobic metabolism of $S$. mutans consumes fermentable sugars (glucose), resulting in acid production, and that the use of a given sugar in the environment depends on the enzyme and transport apparatus that the organism possesses.

\section{LABORATORY TIME}

Our 2-year experience with different student classes shows that two periods of $8 \mathrm{~h}$ separated by an overnight interval are adequate to carry out the experiment as described. An assistant can prepare and autoclave the culture medium and inoculate $12 \mathrm{~h}$ in advance, leaving the students the inoculate of shorter times.

In addition to the study of glucose, the use of other sugars by bacteria can be subjected to the same analysis. Using other sugars does not increase the laboratory time. Another possibility is the addition of agents that affect the cellular metabolism such as antibiotics or fluoride in the culture medium. Fluoride will inhibit the glycolytic pathway, causing an increase of the lag phase of growth from 5 to $\sim 12 \mathrm{~h}$. This effect is due at least in part to enolase inhibition $[16,17]$.

\section{STUDY QUESTIONS}

1. What is the metabolic status of the cells in the lag, log, and stationary phases in the bacterial growth?

2. How is glucose transformed into lactic acid by lactic fermentation? How is the carbohydrate transported to the cell interior?

3. Locate in the pentose phosphate pathway the reactions involved in the reduction potential production and the reactions related to the sugar interconversion with three to seven carbons.

4. Which factors can stop the fermentation of a sugar by a given organism?

5. What is the reason for sugar separation through the TLC plate?

6. What is the role of fluoride in retarding the glucose metabolism?

Acknowledgments - We thank Professor Richard J. Ward and Priscila Cerviglieri for revision of the manuscript.

\section{REFERENCES}

[1] K. W. Stephen, I. G. Chestnutt, T. W. MacFarlane (1994) An in vitro investigation of the cariogenic potential of oral Streptococci, Arch investigation of the can
Oral. Biol. 7, 589-593.

[2] B. Alberts, D. Bray, J. M. Lewis, M. Raff, K. Roberts, J. D. Watson (1994) Molecular Biology of the Cell, 4th ed., Garland Publishing Inc., New York, pp. 79e-793.

[3] J. D. Rawn (1989) Biochemistry, Neil Patterson Publishers, Burlington, NC, pp. $379-406$.

[4] R. W. Hanson (2002) Metabolic minimaps of glycolysis and gluconeogenesis and their regulation, designed by Donald E. Nicholson, Biochem. Mol. Biol. Educ. 30, 3-5.

[5] D. Nicholson (200e) Mitochondrial ATP formation, Biochem. Mol. Biol. Eoduc. 30, 221-223.

[6] D. L. Nelson, M. M. Cox (2000) Lehninger Principles of Biochemistry, 3rd ed., Worth Publishers, New York, pp. 542-683.

[7] J. Van Houte, G. G. Olga, H. V. Jordan (1973) A selective medium for Streotococcus mutans, Arch. Oral Biol. 18, 1357-1364.

[8] S. G. Dashper, E. C. Reynolds (1990) Characterization of transmembrane movement of glucose and glucose analogs in Streptococcus mutans Ingbritt, J. Bacteriol. 172, 556-563.

[9] D. S. Harper, W. S. Loesche (1984) Growth and acid tolerance of human dental plaque bacteria, Arch. Oral. Biol. 10, 843-848.

[10] M. F. Chaplin, J. F. Kennedy, Eds. (1987) Carbohydrate Analysis, a Practical Approach, IRL Press, Oxford, pp. 1-13.

[11] D. C. Harris (1997) Qualitative Chemical Analysis, 5th ed., Freeman, Nesw York.

[12] R. B. Bridges (1977) Ribose biosynthesis in Streptococcus mutans, Arch. Oral Biol. 22, 139-145.

[13] M. R. Wegman, A. D. Eisenberg, M. E. Curzon, S. L. Handelman (1984) Effects of fluoride, lithium, and strontium on intracellular 
184

polysaccharide accumulation in S. mutans and $A$. viscosus, J. Dent. [14] S. W. Leung, C. F. Schachtele (1975) Effect of sugar analogues on growth, sugar utilization, and acid production by Streptococcus $m u-$ [15] G. Rolla (1989) Why is sucrose so cariogenic? The role of glucosyl-
BAMBED, Vol. 31, No. 3, pp. 180-184, 2003

transferase and polysaccharides, Scand. J. Dent. Res. 97, 115-119. 6] R. J. Doyle, S. D. M. Cox, M. O. Lassiter, B. S. Miller (1909) A new mechanism of action of fluoride on streptococci, Biochim. Biophys. Acta 1428, 415-423.

[17] G. N. Jenkins (1999) Review of fluoride research since 1959, Arch. Oral. Biol. 44, 985-992. 


\section{Laboratory Exercises}

\section{The Effect of Carbon Source and Fluoride Concentrations in the Streptococcus mutans Biofilm Formation*}

Received for publication, March 5, 2004, and in revised form, June 3, 2004

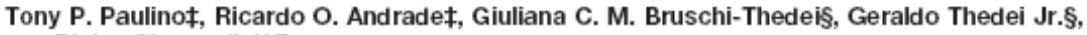
and Pietro Ciancaglinił

From the †Departamento de Química, Faculdade de Filosofia, Ciências e Letras de Ribeiráo Preto, FFCLRP-USP, 14040-901 Ribeirăo Preto, SP, Brazil; §Universidade de Uberaba,

38055-500 Uberaba, MG, Brazil

The main objective of this class experiment is to show the influence of carbon source and of different fluoride concentrations on the biofilm formation by the bacterium Streptococcus mutans. The observation of different biofilm morphology as a function of carbon source and fluoride concentration allows an interesting discussion regarding the metabolic pathways that lead to cavity development, about the role of fluoride on this disease prevention, and also on the importance of biofilm formation to the cariogenic potential of this bacterium, one of the main responsible for this multifatorial disease appearance. On addition to that, the low execution cost and the simple technical apparatus makes this experiment easy to perform.

Keywords: Streptococcus mutans, carbon source, fluoride, biofilm.

Dental cavity is among the most significant human chronic contagious diseases [1] and it is responsible for the irreversible destruction of the mineralized structures of teeth, reaching considerable proportions of dental vitality and of dental element fixation in the maxillo-mandibular complex [2].

Many authors recognized and described the carious process as dependent on the interrelation of four main groups of factors: a MICROBIOTA, formed by a variety of microorganisms, whose metabolic activity produce and liberate acidic compounds that demineralize teeth; a DIET, which should supply oxidizable nutrients by the microbiota component organisms; a HOST that will make microbiota fixation possible, and, finally, these factors should be present (or stay) for a certain TIME, in order for the cariogenic process to occur. It should be noted that for the initiation of this process, all factors should happen simultaneously [3].

Streptococcus mutans is a substantial part of the mouth cell microbiota, which are organized on the surface of the oral cavity of the host (also denominated dental plaque or biofilm). In conditions of excessive proliferation of this biofilm, it contributes with teeth demineralization, leading to cavity development. These bacteria use the carbohy-

- This work was made possible by the continous support of FAPESP, CNPq, CAPES, and Universidade de Uberaba given to our laboratories. T. P. P. is the recipient of a Ph.D. fellowship from CAPES.

If To whom correspondence should be addressed: Departamento de Química, Faculdade de Filosofia, Ciências e Letras de Ribeiräo Preto, FFCLRP-USP, 14040-901 Ribeirảo Preto, SP, Brazil. E-mail: pietro@ffclrp.usp.br.

This paper is available on line at http://www.bambed.org drates present in the diet as an energy source, in an anaerobic process (mainly lactic fermentation) resulting in the production of organic acids [4]. These acids lower the $\mathrm{pH}$ to around 5.0 on the tooth surface [2], inducing its demineralization and causing the disease. The $\mathrm{H}^{+}$extrusion by the bacteria is mainly done by the $\mathrm{F}_{0} \mathrm{~F}_{1}$-ATPase (F-type ATPase) and $\mathrm{H}^{+}$-ATPase (P-type ATPase) as recently described [5]. In contrast to the aerobic organisms, the $\mathrm{F}_{0} \mathrm{~F}_{1}$ - ATPase in $\mathrm{S}$. mutans is a proton-extruding enzyme and not an ATP synthesizer by $\mathrm{H}^{+}$influx $[2,4]$.

Due to the cavity multifactor feature, its control is not limited to a single type of action. A diet that is low in simple sugars, an appropriate hygiene, and treatment with fluoride (whose action involves dental mineralization and microbiota control) can contribute to a significant reduction of this disease. The main objective of this experiment is to discuss the formation of a biofilm composed of $S$. mutans as a function of the carbon source present in the culture medium and the effects of different fluoride concentrations on this structure formation.

BACKGROUND THEORY AND PRE-LABORATORY PREPARATION

The bacterium S. mutans is present in the oral cavity and is one of the main cavity-forming organisms. S. mutans is fast growing in a low cost and easily prepared culture medium, has a metabolic versatility reflected by the utilization of different carbon sources, and is extensively studied [1]. S. mutans is an aero-tolerant bacterium, which does not have a respiratory chain and produces ATP by anaerobic glycolysis $[2,4]$.

It is well characterized that adhesion of $S$. mutans to the dental surface, forming the dental plaque, is dependant on 
the production of high molecular weight D-glucose polymers called glucans (or dextran) from sucrose by enzymes called glucansucrases (EC 2.4.5.1). These extracellular enzymes are produced mainly by soil bacterium Leuconostoc mesenteroides, by lactic bacteria Lactococci and Streptococcus species from the oral flora (commonly termed glucosyltransferases). Glucansucrases produced by $S$. mutans and S. sobrinus play a key role in the cariogenesis process, because the glucan produced enhances the attachment and colonization of cariogenic bacteria [6]. These enzymes catalyze the transfer of glucosyl residues coming from sucrose cleavage. The dextran synthesis reaction occurs by successive transfer of glucosyl units to the polymer. Because sucrose is the main substrate for the glucosyl transferase enzyme, the high cariogenic potential of this sugar is thereby explained [7]. Strains of S. mutans deficient on this enzyme do not form biofilm and, consequently, are less cariogenic. Also, glucansucrases can transfer glucosyl units onto water molecules and simply hydrolyze sucrose, allowing its utilization as a carbon source for the energetic requirements of the bacterium [6].

Fluoride use as a caries reduction agent is well known, and the available clinical evidence supports the use of up to $2 \%(\mathrm{w} / \mathrm{v})$ of fluoride, equivalent to $\sim 0.5 \mathrm{M}$ (www. ada.org/public/topics/fluoride/facts/safety.asp). Among the action mechanisms proposed by the caries reduction, fluoride's ability to promote remineralization of acid-demineralized teeth, the inhibition of the glycolytic enzyme enolase, and cellular aggregation mediated by glucanbinding proteins $[8,9]$ can be mentioned. The inhibition of enolases not only induces a stop of glycolysis, but also reduces glucose uptake, because one of the systems for absorption of this sugar in streptococci involves the phosphoenolpyruvic acid (PEP, a product of enolase over the phosphoglyceric acid), thus depriving the cell of glucose and, consequently, of energy. The combination of these effects may be related to the reported beneficial effects of fluoride on oral health [8].

The simple experiment proposed here permits the discussion of essential aspects of sugar metabolism and biofilm formation. To profit from this practice, the students should know the basics of these topics.

\section{GENERAL NOTES}

In this class experiment, we describe a methodology adapted to the use of $S$. mutans, which can be acquired commercially. There is a possibility of isolating a lineage of S. mutans, inoculating a saliva sample in a selective culture medium mitis salivarius bacitracin sucrose (MSBS) [10].

Strain-The ATCC 25175 strain of S. mutans is available from the André Tosello Foundation (Campinas-SP, Brazil; www.bdt.fat.org.br). The lineage is stored in $-20^{\circ} \mathrm{C}$ in $40 \%$ (v/v) glycerol.

Liquid Medium-The complete medium described by Dhasper and Reynolds [11] was used. This medium was composed by $10 \mathrm{~g} /$ /iter triptone, $5 \mathrm{~g} /$ liter yeast extract, 60 $\mu \mathrm{M} \mathrm{MgSO}_{4}, 1.3 \mu \mathrm{M} \mathrm{FeSO}_{4}, 1.5 \mu \mathrm{M} \mathrm{MnCl}_{2}, 0.2 \mathrm{~mm} \mathrm{KH}_{2} \mathrm{PO}_{4}$, $0.3 \mathrm{mM} \mathrm{K}_{2} \mathrm{HPO}_{4}, 0.7 \mathrm{~mm} \mathrm{KCl}$, and autoclaved at $121^{\circ} \mathrm{C}$ during $15 \mathrm{~min}$.

Sugars Solutions-Each stock sugar solution (glucose, xylose, sucrose, fructose) used to complement the complete culture medium was prepared at a final concentration of $2 \mathrm{M}$ and autoclaved at $121^{\circ} \mathrm{C}$ for $15 \mathrm{~min}$. Maltose stock solution was $1 \mathrm{~m}$, autoclaved under the same condition.

Growth Conditions-All cultivations were done in a candle jar, at $37^{\circ} \mathrm{C}$ for $24 \mathrm{~h}$, in a micro-aerophilic atmosphere obtained after lighting a candle inside the jar to consume part of the oxygen.

Preinoculate-Stock strain was submitted to three successive transferences ( $12 \mathrm{~h}$ incubation) in tryptic soy broth medium in order to reestablish their normal metabolism. The turbidity of the preinoculate was adjusted to $\mathrm{A}_{600 \mathrm{~nm}}=$ 0.5 , corresponding to $\sim 10^{9}$ cells $/ \mathrm{ml}$ (for details see Ref. 12).

Biofilm Formation-The liquid medium was supplemented with the carbon source as indicated $(1 \% \mathrm{w} / \mathrm{v}$, final concentration) and distributed into 24-wells cell culture cluster (Corning Costar 3524, flat bottom; Coming, NY) (1 $\mathrm{m} / \mathrm{well})$. Each well was inoculated with $15 \mu \mathrm{l}$ of the preinoculate and incubated for $12 \mathrm{~h}$ as described in growth conditions. After this period, the medium was removed and the wells were washed with phosphate-buffered saline $\left(0.13 \mathrm{M} \mathrm{NaCl}, 2.7 \mathrm{~mm} \mathrm{KCl}, 8.1 \mathrm{~mm} \mathrm{Na} \mathrm{HPO}_{4}, 1.47 \mathrm{~mm}\right.$ $\mathrm{KH}_{2} \mathrm{PO}_{4}$ ), $\mathrm{pH} 7.4$, dried at room temperature and photographed with a stereomicroscope (Leica model MZ FLIII; Deerfield, IL).

Cell Disposal-The cells that were not used or remained from the experiment were autoclaved at $121^{\circ} \mathrm{C}$ for $20 \mathrm{~min}$ and then discarded.

\section{STUDENT PITFALLS}

This is a very easy class experiment, but some problems such as culture contamination may occur as a result of bad manipulation.

\section{RESULTS AND DISCUSSION}

S. mutans is a bacterium normally present in the bucal microbiota, and its relation to the appearance of caries is evident. This relation is due to its high growth capacity and production of organic acids, such as lactic, propionic, and acetic [1].

Fig. 1 shows a picture without enlargement of the 24well cell culture 7 cluster, after $12 \mathrm{~h}$ growth. The biofilm can be visualized by the opaque appearance of the bottom of the well. Its intensity varies as a function of the carbon source and fluoride concentration. In fact, in column 5 (sucrose growth) a more intense biofilm is observed, also in the presence of $5 \mathrm{~mm}$ of fluoride (column 5 , lane D), whereas in column 3 (glucose growth) a less intense biofilm is formed. Also, this biofilm is progressively reduced with the increase of fluoride concentration (column 3 , lanes $B-D)$. The same observation is made for growth in the presence of maltose (column 1) and fructose (column 4). When xylose or no carbon source is added to the growth medium, no biofilm is observed through the naked eye (or without the use of a stereomicroscope), as shown in column 2 and 6 , respectively.

Fig. 2 shows the morphology of the biofilm formed by S. mutans after 12-h growth in the tested conditions. Using glucose, fructose, or maltose as a carbon source, the formation of a homogeneous layer is observed, which 


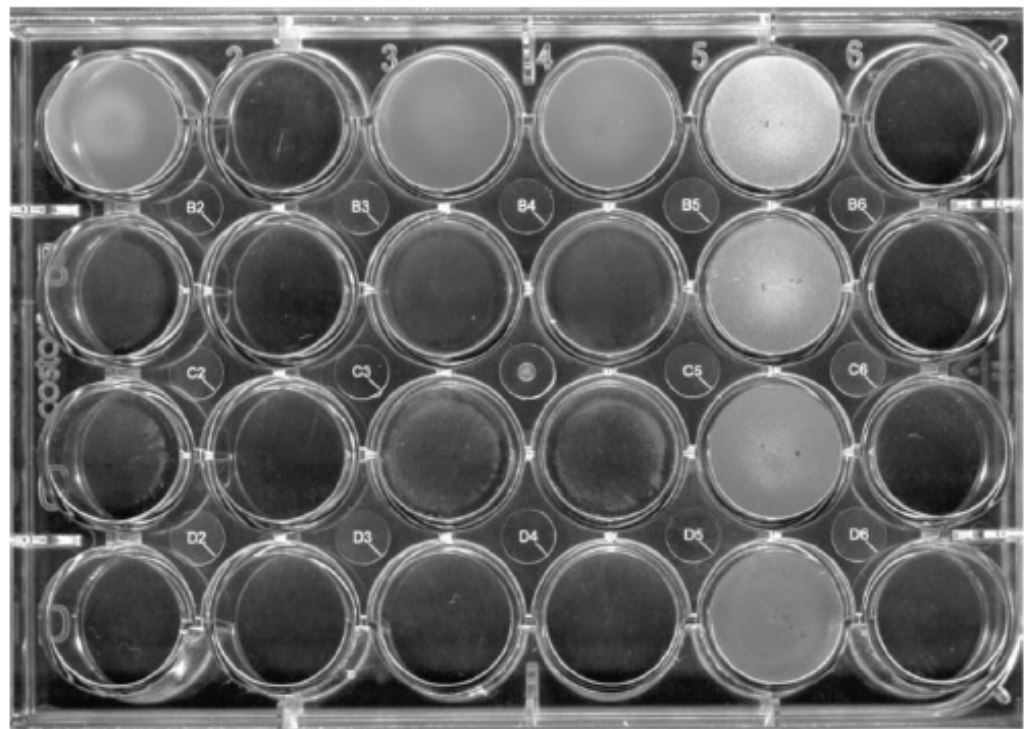

Fig. 1. View of a 24-wells cell culture cluster after $12 \mathrm{~h}$ of $S$. mutans growth in anaerobiose in complete medium supplemented with $1 \%(\mathrm{w} / \mathrm{v})$ of the carbohydrate. Column 1 , maltose; 2 , xylose; 3, glucose; 4, fructose; 5 , sucrose; 6, control (without carbon source). Lane $A$, without fluoride; $B, C$, and $D$, with 1,3 , and 5 mmolliter of NaF, respectively.

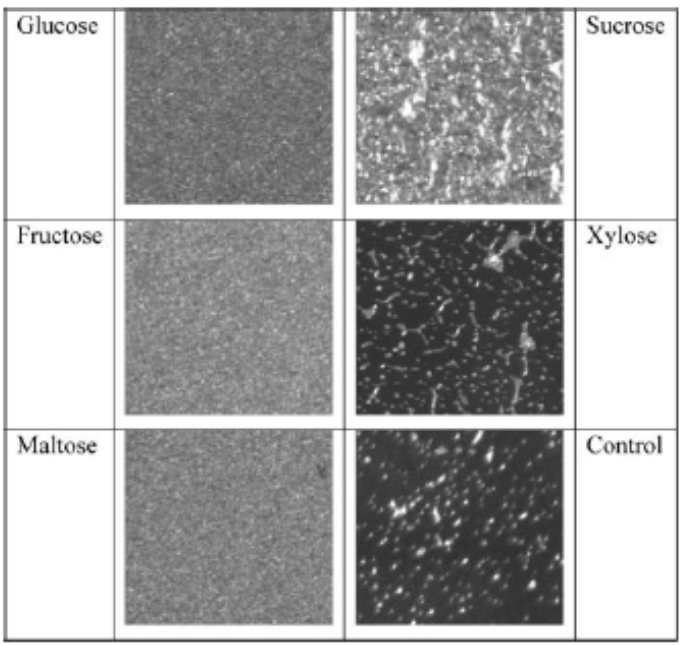

FIG. 2. Micrography of the biofilm formed by S. mutans after growth during $12 \mathrm{~h}$ in anaerobiose in complete medium supplemented with $1 \%(w / v)$ of the carbohydrate, as indicated. The control is a biofilm formed in complete media not supplemented with carbohydrate $(100 \times)$.

totally occupies the bottom of the well. When using sucrose, the total occupation of the bottom of the well will occur, but the surface appearance of the biofilm formed is irregular. This fact is due, at least in part, to the production of extracellular polyssacharides when the sucrose is the carbon source. These sugars affect the cell morphology, as described by Moro et al. [13]. Xylose has not promoted the homogeneous occupation of the well, a result that is very similar to the one found when the growth is done without the addition of a carbon source. This reinforces the suggestion of Paulino et al. [12], wherein media without the addition of carbohydrate or supplemented only with xylose the growth is insignificant, as well as the acidification of the culture media, possibly due to the small quantity of fermentable sugar, restricted to the intracellular reserves, possibly in the form of polysaccharides, as already described [14]. These reserves would be enough to start the growth, but they would soon be depleted.

The addition of increasing fluoride concentrations to the media supplemented with glucose, fructose, and maltose produced a very similar effect, with the gradual reduction of the well's bottom coverage, opening small areas without cell attachment ( $1 \mathrm{~mm} \mathrm{NaF}$ ), more extensive areas without cell attachment ( $3 \mathrm{~mm} \mathrm{NaF}$ ), reaching isolated colonies (5 $\mathrm{mm} \mathrm{NaF)}$ as shown in Fig. 3. The effect of fluoride on biofilm formation in the presence of sucrose was less intense, because in that with $5 \mathrm{~mm}$ of $\mathrm{NaF}$, the well's bottom coverage was still very significant, and isolated colonies were not observed as in other sugars. Apparently, the microorganism becomes less sensitive to fluoride when the growth is done in the presence of sucrose as a carbon source. Alternatively, but not exclusively, the fluoride can be decreasing the bonding ability to the substrate (and, with this, the ability to form the biofilm) with more efficiency in media supplemented with carbohydrates different from sucrose. When xylose is the carbon source, the growth reduction was also observed, although less significant, because the growth observed in the absence of fluoride was less intense, as previously described [12]. The same result was observed when no source of carbon was 
Fig. 3. Micrography of the biofilm formed by $S$. mutans after growth during $12 \mathrm{~h}$ in anaerobiose in complete medium supplemented with $1 \%(w / v)$ of the carbohydrate in the presence of increasing concentrations of $\mathrm{NaF}$, as indicated $(100 \times)$.

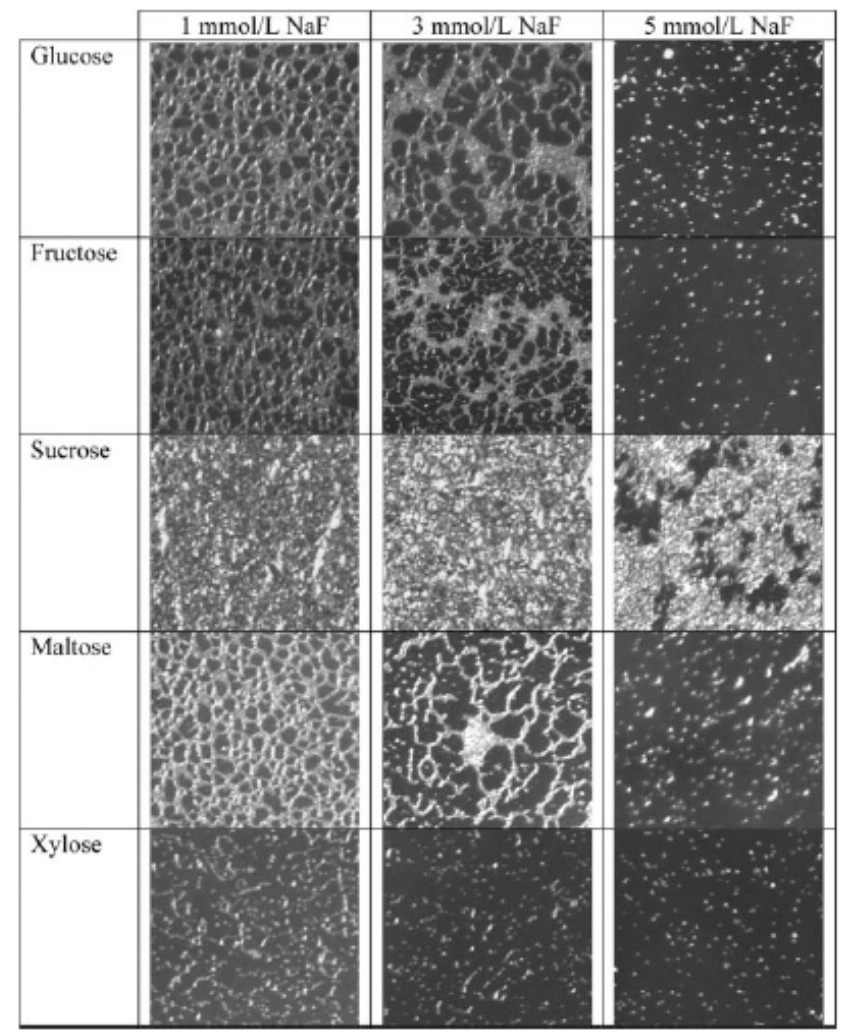

added to the media (data not shown), favoring the conclusion that even the intracellular sources' metabolism are harmed by fluoride, possibly by blocking the enolase enzyme, resulting in the stop of glycolytic pathway and energy (ATP) production, as described by Cox et al. [8].

Studies reveal that cells of $S$. mutans metabolizing glucose at $\mathrm{pH} 5.5$ will require 10 - to 12 -fold less fluoride to complete inhibition than cells incubated at $\mathrm{pH}$ 7.0. Thus, in the presence of fluoride, this oral bacteria will be progressively more inhibited by fluoride as the $\mathrm{pH}$ declines as a consequence of metabolism, which can be interpreted as a "self-regulating process" [15].

In conclusion, this class experiment shows that S. mutans forms a biofilm independent of the carbon source used, as long as this source is metabolized by the organism. The formation of this biofilm is significantly affected by increasing concentrations of fluoride, possibly by the blockage of the glycolytic activity and/or decrease of the substrate adhesion.

\section{LABORATORY TIME}

Our 1-year experience with different student classes shows that two periods of $4 \mathrm{~h}$ separated by an overnight interval are adequate to carry out the experiment as described. An assistant can prepare and autoclave the culture medium and prepare the preinoculate in advance, leaving the students the inoculate of well cell culture cluster and observation of the results.

\section{STUDY QUESTIONS}

1. Why does enolase inhibition decrease bacterial growth?

2. How is glucose transformed into lactic acid by lactic fermentation?

3. How is the glucose transported to the cell interior?

4. Why don't bacteria without glucansucrase form biofilm?

5. Why does the biofilm formation favor dental cavity development?

6. Describe the possible effects of fluoride on dental cavity control.

7. Why is sucrose more cariogenic than glucose or maltose?

Acknowledgments - We thank Priscila Cerviglieri for revision of the manuscript.

\section{REFERENCES}

[1] K. W. Stephen, I. G. Chestnutt, T. W. MacFarlane (1994) An in vitro investigation of the cariogenic potential of oral Streptococci, Arch. investigation of the cario
Oral Biol. 7, 589-593.

[2] J. D. Rawn (1989) Biochemistry, pp. 379-406, Neil Patterson Publishers, Burlington, VT.

[3] K. Simon, J. L. Mc Donald, G. K. Stookey (1979) Preventive Dentistry in Action, pp. 140-145, D. C. P. Publishing, Upper Montclair, NJ.

[4] B. Alberts, D. Bray, J. M. Lewis, M. Raff, K. Roberts, J. D. Watson (1994) Molecular Biology of the Celi, 4th Ed., pp. 792-793, Garland Publishing Inc., New York, NY.

[5] P. P. Magalhaes, T. P. Paulino, G. Thedei, Jr., R. E. Larson, P. Ciancaglini (2003) A $100 \mathrm{kDa}$ vanadate and lanzoprazole-sensitive 
815-824.

[6] V. Monchois, R. Willemot, P. Monsan (1999) Glucansucrases: Mechanism of action and structure-function relationships, FEMS Microbio. Rev. 23, 131-151.

[7] G. Rolla (1969) Why is sucrose so cariogenic? The role of glucosyltransferase and polysaccharides, Scand. J. Dent. Res. 97, 115-11. [8] S. D. Cox, M. O. Lassiter, B. S. Miller, R. J. Doyle. (1999) A new mechanism of action of fluoride on streptococci, Biochim. Biophys. Acta 1428, 415-423.

[9] S. Luengpailin, J. A. Banas and R. J. Doyle (2000) Modulation of glucan binding protein activity in streptococci by fluoride. Biochim. Biophys. Acte, 1474, 346-352.

[10] J. Van Houte, G. G. Olga, H. V. Jordan (1973) A selective medium for Streptococous mutans, Archs. Oral Biol. 18, 1357-1364.

[11] S. G. Dashper, E. C. Reynolds (1990) Characterization of transmem- brane movement of glucose and glucose analogs in Streptococcus mutans ingbritt, J. Bacteriol. 172, 556-563.

[12] T. P. Paulino, M. Cardoso Jr., G. C. M. Bruschi-Thedei, P. Ciancaglini (2003) Fermentable and non-fermentable sugars. A simple experiment of anaerobic metabolism, Biochem. Mol. Biol. Educ. 31, $180-184$

[13] I. Moro, Y. Toda, T. Koga, S. Hamada (1986) Morphological aspects of Streptococcus mutans, in Molecular Microbiology and immunology of Streptoccus mutans (S. Hamada et al., eds.) pp. 81-90, Elsevier Science Publishers B. V., Oxford, United Kingdom.

[14] R. B. Bridges (1977) Ribose biosyntesis in Streptocoocus mutans, Arch. Oral Biol. 22, 139-145.

[15] O. Fejerskov, J. Ekstrand, B. A. Burt (1996) Fluoride in Dentistry, 2nd Ed., pp. 230-251, Munksgaard, Copenhagen, Denmark. 


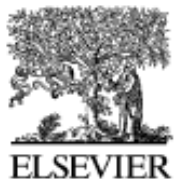

\author{
(5) \\ Available online at www.sciencedirect.com \\ science doinect
}

Archives

of

Oral

ELSEVIER

Biology

\title{
Use of hand held photopolymerizer to photoinactivate Streptococcus mutans
}

\author{
Tony P. Paulino ${ }^{a}$, Karina F. Ribeiro ${ }^{a}$, Geraldo Thedei Jr. ${ }^{b}$, \\ Antônio C. Tedesco ${ }^{a}$, Pietro Ciancaglini, * \\ ${ }^{a}$ Departamento de Química, Faculdade de Filosofia, Ciências e Letras de Ribeirão Preto, \\ FFCLRP-USP, 14040-901 Ribeirão Preto, SP, Brazil \\ 'Universidade de Uberaba, 38.055-500 Uberaba, MG, Brazil
}

Accepted 17 September 2004

\section{KEYWORDS \\ Hand held \\ photopolymerizer; \\ Streptococcus mutans; \\ Fibroblasts; \\ Photodynamic therapy; \\ Rose Bengal}

www.intl.elsevierheal th.com/journals/arob

\begin{abstract}
Summary
Objectives: The main focus of this research was to investigate the photodynamic therapy (PDT), in vitro, acting on Streptococcus mutans and fibroblasts. A hand held photopolymerizer (HHP) and a classical photosensitizer (Rose Bengal) were used to induce photodynamic response.

Methods: S. mutans and fibroblast were treated with different concentrations of Rose Bengal $(0-50 \mu \mathrm{M})$ irradiated with light $(400-500 \mathrm{~nm})$ for different time periods (0$40 \mathrm{~s})$ and then cell viability was evaluated.

Results: It was observed that the light (per se) is not toxic and in the dark Rose Bengal is toxic to the cells tested only at concentrations above $2.5 \mu \mathrm{M}$. Under light exposure concentrations of Rose Bengal above $0.5 \mu \mathrm{M}$ all S. mutans were killed with no cytotoxic effects to fibroblasts.

Conclusions: For the purpose of this work, the photoactivation of Rose Bengal, using the HHP, inactivated the bacteria without affecting the fibroblast viability.

(c) 2004 Elsevier Ltd. All rights reserved.
\end{abstract}

\section{Introduction}

Dental caries is among the most significant human chronicle contagious diseases, which affects primarily underdeveloped countries and low income populations and/or immune compromised patients. ${ }^{1-3}$

The existence of the disease is due to several interacting factors which results in the irreversible

\footnotetext{
* Corresponding author. Tel.: +55 16602 3753;

fax: +55 166338151 .

E-mail address: pietro@ffclrp.usp.br (P. Ciancaglini).
}

destruction of the mineralized structures of teeth, reaching compromising proportions of dental vitality and of dental element fixation in the maxillomandibular complex. ${ }^{4}$

The Gram positive bacteria Streptococcus sobrinus and Streptococcus mutans are a substantial part of the dental plaque microbiota and its importance in the dental caries etiology is unquestionable. ${ }^{5}$

Bacterial strains use the carbohydrates present in the diet as an energy source, in an anaerobic process (mainly lactic fermentation) resulting in the produc-

0003-9969/\$ - see front matter 2004 Elsevier Ltd. All rights reserved. doi: $10.1016 /$ j.archoralbio. 2004.09 .002 
tion of organic acids. These acids lower the $\mathrm{pH}$ to around 4.5 on the tooth surface, ${ }^{6}$ inducing its demineralization.

A number of works have been developed to control bacterial proliferation in the mouth environments including: (i) vaccine production; ${ }^{2}$ (ii) fluoride therapy ${ }^{7}$ and (iii) antibiotic therapy. ${ }^{8}$

Wallman et al. ${ }^{9}$ comments on the difficulty in obtaining a long and significant decrease in the $S$. mutans resident cells after treatment with chlorhexidine. Therefore, it is recommended to combine a reduction in the sucrose level (from dietary habits) in patients associated with the conventional antimicrobial treatment. Such findings reinforces the theory that several different forms of resistance to the conventional antimicrobial treatment are arising. ${ }^{9}$

The increasing resistance of bacteria like S. sobrinus and S. mutans makes the development of alternative antimicrobial techniques an important research focus. ${ }^{10}$

In the search for new strategies against microorganisms, studies using photodynamic therapy (PDT) have been routinely used in bacteria, ${ }^{11}$ yeast ${ }^{12}$ and virus, ${ }^{13}$ including HIV $^{14}$ inactivation.

PDT is a therapy modality which employs the combination of visible light, a drug (called photosensitizer or dye) and molecular oxygen usually present in the tissue. This photosensitive agent can be a molecule normally present in cells and tissues, but in the specific case of PDT it administration is generally the first step in the treatment process. In the second step, the targeted tissue is exposed to visible light at a specific wavelength (specific for each dye), which is absorbed by the photosensitive agent. The dye or light alone isnot cytotoxic, at least not in the phototherapeutical active drug doses. Nevertheless, the combination of the two agents in the presence of oxygen leads to the production of different reactive oxygen species (ROS) such as singlet oxygen$-{ }^{1} \mathrm{O}_{2}$, among others ${ }^{15,16}$ which will lead to a sequence of biological events resulting in the apoptosis of the cells ${ }^{17,18}$ or death of the microorganisms. ${ }^{19}$

Among the various photosensitive agent used in PDT are the merocyanine derivatives, phtalocyanines, hematoporphyrin and xanthenes dyes. ${ }^{16}$

Specific studies, using laser light irradiation, indicate that certain oral bacteria including $S$. mutans and S. sobrinus, can be efficiently inactivated after PDT with dyes as toluidine blue and methylene blue ${ }^{20-22}$ or even with more complex molecules as dissulphonated phtalocyanin aluminum. ${ }^{23}$ Wood et al. ${ }^{24}$ have evaluated an in vitro study to test the PDT using a removable system implant attached to the teeth of volunteers that allows establishing a biofilm. After selected time periods, the biofouled implant was removed and PDT treated with phtalocyanines derivatives. The results shown by these authors include the occurrence of damage in bacterial membranes and cytoplasmatic vacuolation, indicating that PDT affected the bacterial structure.

The use of dye derivated from porphyrins has been proven to be efficient in controlling Gram positive microorganisms. ${ }^{19,25,26}$ These studies results are encouraging and indicate a new possibility for bacterial control.

In PDT studies, Rose Bengal (a xanthene derivate) has been used as a model compound with excellent photophysical properties, ${ }^{27}$ whereas not indicated for clinical use. This dye has an absorption in the region of $500 \mathrm{~nm}$ and a good quantum yield of singlet oxygen production. ${ }^{28}$ In recent studies, Wachter et al. ${ }^{29}$ have shown that PDT with Rose Bengal, at light intensities bellow $100 \mathrm{~J} / \mathrm{cm}^{2}$, have exhibited no significant acute cutaneous toxicity in normal skin, allowing it to be used for PDT treatment of skin disorders.

Dahl et al. ${ }^{30}$ reported a comparison of photodynamic action (PDT) by Rose Bengal in Gram positive (S. salivarius, S. faecalis, S. aureus and Bacillus subtilis) and Gram negative bacteria (Salmonella typhimurium). In these studies, $5 \mu \mathrm{M}$ of Rose Bengal was used (pre incubated in the dark for 30-180 min.) and PDT was induced using a tungsten lamp. In these conditions, a Gram positive species were inactivated about 200 times more quickly ( $99 \%$ inactivation) than a Gram negative species.

Although most PDT applications are associated with a laser light, non-laser light sources have also been used. ${ }^{31}$ Studies developed in the last decade clearly indicate that the use of the visible-light isolated from a hand held photopolymerizer unit (non-laser light source) does not induce any thermal or photochemical damage to the retina. ${ }^{32}$ There is also the complete absence of visual damage to the patient or to the technician due to UV-A or UV-B irradiation presented in lower doses in the light spectrum. In addition to that, the cost of use of HHP is lower than of laser light. ${ }^{33}$

In the present study, we evaluated the PDT effect on S. mutans and fibroblasts, previously treated with different photosensitive concentrations of Rose Bengal, using the hand held photopolimerizer (HHP) as a light source. The results showed the complete bacterial inactivation without affecting the fibroblasts viability or any other side effect. 


\section{Material and methods}

\section{Hand-held photopolymerizer}

The hand held photopolymerizer or dental photopolymerizer (HHP) was purchased from Dabi Atlante SA (Ribeirão Preto-SP, Brasil) and was used as the light source in all experiments. The HHP has the following characteristics: $350-500 \mathrm{~mJ} / \mathrm{cm}^{2}$ of light emitted at a wavelength range of $400-500 \mathrm{~nm}$.

\section{Preparation of stock solution}

Rose Bengal (Sigma-St. Louis, MO, USA) was used as a stock solution, in PBS (phosphate saline buffer; $\mathrm{NaCl}$ $0.13 \mathrm{M}, \mathrm{KCl} 2.7 \mathrm{mM}, \mathrm{Na}_{2} \mathrm{HPO}_{4} 8.1 \mathrm{mM}$ and $\mathrm{KH}_{2} \mathrm{PO}_{4}$ $1.47 \mathrm{mM}$, final $\mathrm{pH} 7.4$ ) at a concentration of $2 \mathrm{mM}$. This solution was filter sterilized $(0.22 \mu \mathrm{m})$ and stored at $-20^{\circ} \mathrm{C}$.

\section{S. mutans growth conditions}

The ATCC 25175 strain of S. mutans is available from the André Tosello Foundation, Campinas-SP (Brazil). The lineage is stored in $-20^{\circ} \mathrm{C}$ in $40 \%(\mathrm{v} / \mathrm{v})$ glycerol (Sigma, St. Louis, MO, USA) medium and checked for purity before being grown in broth. The liquid media used to cultivate and check the cells viability was a triptic soy broth (TSB-soybean-case in digest medium) or tryptic soy agar (TSA-soybean-casein digest agar) from Difco, Sparks, MD, USA, prepared, according to the manufacturer's instructions and autoclaved at $121^{\circ} \mathrm{C}$ during $15 \mathrm{~min}$ prior to use. All the cultivations were done in a candle jar, in a micro-aerophilic atmosphere, obtained after lighting a candle inside the jar to consume part of the oxygen. For microbial assays, the initial turbidity of the bacteria culture was adjusted to $A_{600 \mathrm{~nm}}=0.5$ ( $\sim 10^{9}$ cells $/ \mathrm{ml}$ ) using a spectrophotometer (Milton Roy, Spectronic, Genesys 2). Then, $15 \mu$ l of the stock was inoculated in "falcon tubes" (15 ml)containing $4 \mathrm{ml}$ of previously autoclaved TSB medium. The initial number of colony forming units per milliliter (CFU/ $\mathrm{ml}$ ) was estimated by measuring the suspension turbidity with a spectrophotometer and verified by using CFU $/ \mathrm{ml}$ counts on TSA after anaerobic growth at $37{ }^{\circ} \mathrm{C}$ for $36 \mathrm{~h} .{ }^{34}$

Cytotoxic effects of phototherapy in S. mutans in the presence and absence of light

Before the incubation with different concentrations of Rose Bengal, the cells $\left(A_{600 \mathrm{~nm}}=0.5\right)$ were serially diluted in PBS to obtain a $10^{3} \mathrm{CFU} / \mathrm{ml}$ and distributed $(1 \mathrm{ml})$ in assay tubes $(125 \mathrm{~mm} \times 15 \mathrm{~mm})$. One set of tubes was submitted to a control cell experi- ment to evaluate the dye toxicity per se in the dark and the light toxicity per se without any dye. The other set was submitted to a cell killing experiment with variable concentrations of Rose Bengal (ranging from 0 to $50 \mu \mathrm{M}$ ) under light exposure.

Light exposure was performed using HHP tip at $11 \mathrm{~cm}$ distance from the cell suspension after gentle stirring of assay tube for $10 \mathrm{~min}$. This was carried out for two different reasons. The first was to evaluate the light toxicity per se, in which the cell suspension $(1 \mathrm{ml})$ without incubation with the dye was exposed to $433.2 \mathrm{~mJ} / \mathrm{cm}^{2}$ (equivalent to $40 \mathrm{~s}$ pulse of light). Secondly, to promote the cell inactivation, in which the dye treated cells (concentration range from 0 to $50 \mu \mathrm{M}$ ) were submitted to different times of light exposure $(0-40 \mathrm{~s})$ under a stable irradiation power.

The dye toxicity per se (in the dark) was performed in the same way, only without the light exposure.

Cells were grown by dropping and spreading $50 \mu \mathrm{l}$ of cell suspension directly onto TSA, and incubating it (protected from light) in a candle jar for $36 \mathrm{~h}$ at $37^{\circ} \mathrm{C}$. After this time, the CFU/ml was calculated.

\section{Fibroblasts growth conditions}

The fibroblasts strains were obtained from ATCC (CCL-110) as a stock cell line and kept frozen in liquid nitrogen with fetal bovine serum (FBS) and DMSO $(9: 1(\mathrm{v} / \mathrm{v}))$. After the defrosting process, the fibroblasts were grown in a 24 well cell culture cluster with a Dulbecco's modified eagle/medium $\mathrm{F}-12$ nutrient medium (DMEM/F12) from GIBCO Invitrogen Corp., prepared according to the manufacturer's instructions, filtered through a $0.22 \mu \mathrm{m}$ membrane. The final medium was enriched with $10 \%$ FBS, penicillin $100 \mathrm{U} / \mathrm{ml}$, streptomycin $100 \mu \mathrm{g} / \mathrm{ml}$ and anphotericin $0.25 \mu \mathrm{g} / \mathrm{ml}$.

Medium was changed twice a week, and fibroblasts were transferred when they reached a confluent population of cells with approximate $1 \times 10^{6}$ cells $/ \mathrm{ml}$. This amount of cells was isolated by centrifugation and washed twice with a Hank's balanced salt solution (HBSS, from GIBCO Invitrogen corp. Grand Island, NY, USA). The initial cell concentration used in all experiments was setup to $0.7 \times 10^{6} \mathrm{cell} / \mathrm{ml}$ in HBSS.

Cytotoxic effects of phototherapy in fibroblasts in the presence and absence of light

One milliliter of the cell suspension $\left(0.7 \times 10^{6}\right.$ cells $)$ was distributed in assay tubes $(125 \mathrm{~mm} \times 15 \mathrm{~mm})$ to evaluate the light toxicity at variable intensities of 
light with or without dye, as previously described for S. mutans.

After the experiments, the cells were isolated by centrifugation, washed twice with HBSS and put in DMEM/F-12 growth medium. Afterwards, the culture was incubated for $24 \mathrm{~h}$ at $37^{\circ} \mathrm{C}$ in a $\mathrm{CO}_{2}$ incubator. The cells viability was calculated using a Neubauer's chamber based on the Trypan Blue exclusion test. ${ }^{35}$

\section{Statistical analysis}

Data are reported as the mean of triplicate measurement of three different preparations which was considered to be statistically significant at $P \leq 0.05$.

\section{Results}

Fig. 1 shows the characteristic absorption spectra for a $4.0 \mu \mathrm{M}$ Rose Bengal PBS solution. It is worth emphasizing that this xanthene derivate presents an absorption band in the range of 450-600 nm, which is coincident with the emission spectra of conven tional HHP (400-500 nm), suggesting that it can be used to photoactivate the dye. The Rose Bengal absorption spectra, obtained in the presence of

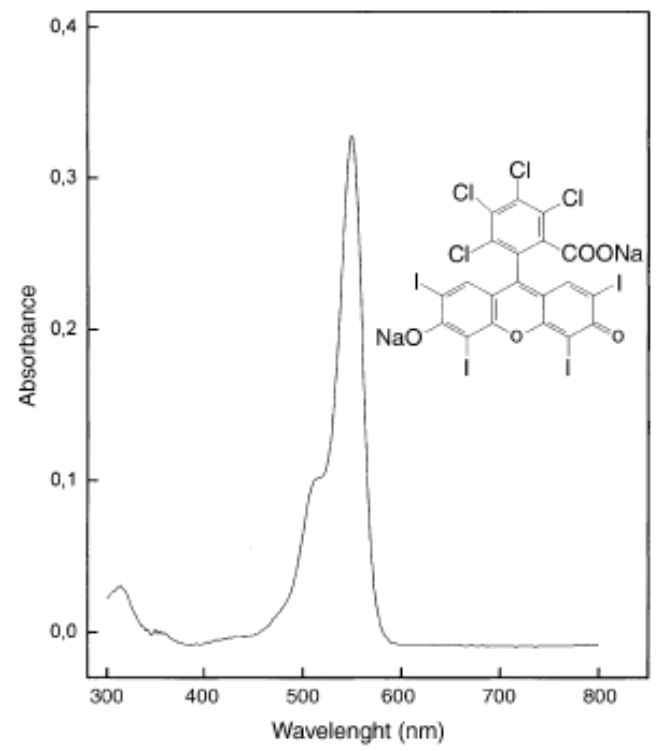

Figure 1 Absorption spectra of $4.0 \mu \mathrm{M}$ Rose Bengal in phosphate buffer saline pH 7.4 (PBS) in the presence or absence of cells (fibroblasts or S. mutans), using as reference the cuvette with a cell (or bacterial) suspension. Inset: Rose Bengal structure.
$10^{3} \mathrm{CFU} / \mathrm{ml}$ of S. mutans or $10^{6}$ fibroblasts, do not show any alteration (data not shown).

In the dark toxicity assays, it was demonstrated that, in concentrations bellow $5 \mu \mathrm{M}$, Rose Bengal does not show toxicity to S. mutans (Fig. 2) as well as to fibroblasts (insert Fig. 2). In concentrations above this value, an exponential increase of toxicity occurs for both types of cells.

Fig. 2 also shows that death induced by Rose Bengal treatment, followed by visible light irradiation $\left(325.1 \mathrm{~mJ} / \mathrm{cm}^{2}\right.$, which corresponds to a $30 \mathrm{~s}$ pulse of the HHP), is dose dependent for both $S$. mutans and fibroblasts.

At $0.5 \mu \mathrm{M}$ (which corresponds to $0.5 \mu \mathrm{g} / \mathrm{ml}$ ) Rose Bengal, $100 \%$ of cell death for S. mutans (Fig. 2) was observed, while for fibroblasts this concentration did not affect cell viability (insert Fig. 2), under the same assay conditions. It was also observed that without Rose Bengal, light intensities up to $433.2 \mathrm{~mJ} / \mathrm{cm}^{2}$ did not affect the viability of any type of cells.

To determine the effectiveness of PDT, we have evaluated the effect of the light dose over the mortality of $\mathrm{S}$. mutans and fibroblasts previously incubated with $0.5 \mu \mathrm{M}$ of Rose Bengal for $10 \mathrm{~min}$. Dose dependant cell mortality from 54.5 to $216.6 \mathrm{~mJ} / \mathrm{cm}^{2}$ for S. mutans was clearly observed (Fig. 3). Doses over $216.6 \mathrm{~mJ} / \mathrm{cm}^{2}$ (this value corresponding to a pulse of $20 \mathrm{~s}$ of the HHP) and up to $433.2 \mathrm{~mJ} / \mathrm{cm}^{2}$ caused $100 \%$ cell death of $S$. mutans.

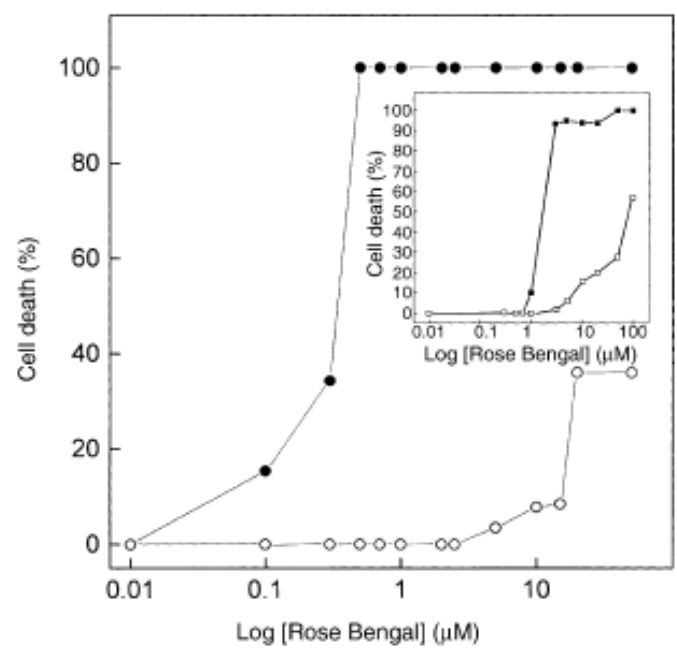

Figure 2 S. mutans viability in the presence of variable concentrations of Rose Bengal in the dark with $(\bullet)$ or without $(O)$ light irradiation $\left(325.1 \mathrm{~mJ} / \mathrm{cm}^{2}\right)$ using a HHP. Inset: fibroblast viability in the presence of variable concentrations of Rose Bengal in the dark with ( $\mathbf{\square})$ or without (口) light irradiation $\left(325.1 \mathrm{~mJ} / \mathrm{cm}^{2}\right)$ using a HHP. 


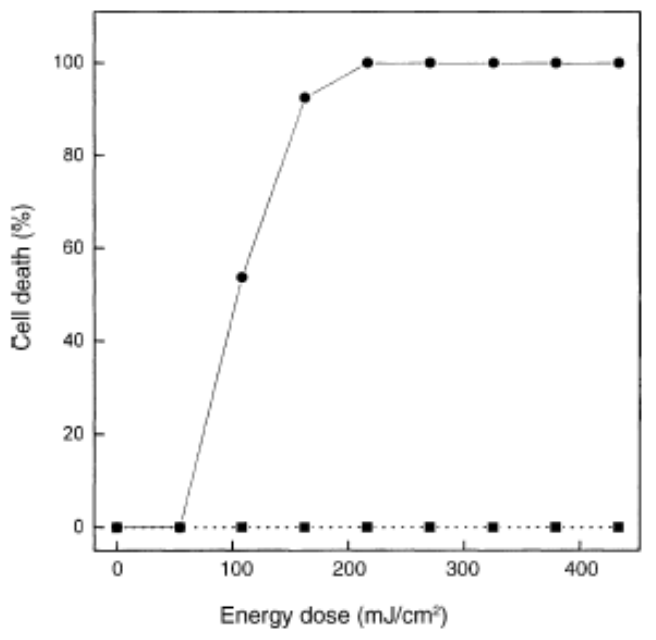

Figure 3 S. mutans and fibroblasts viability using different energy doses. $10^{3} \mathrm{CFU}$ of bacteria (-) or $10^{6}$ fibroblasts ( $\mathbf{\square})$ were incubated with different energy doses using a HHP and grown in TSA medium (S. mutans) or DMEN/F12 (fibroblast) for $36 \mathrm{~h}$ as described in 'Material and methods'.

Under these experimental conditions, no effect over fibroblasts viability was observed (Fig. 3).

\section{Discussion}

The use of PDT as a technique to inactivate microorganisms has a considerable medical and technological impact, in addition to being a complementary and alternative method compared to the classical antibiotic therapy for bacterial disease control. ${ }^{36}$ The expansion of the PDT application field has been emerging in response to the development of new drugs with low toxicity and high efficiency generating ROS to specific cellular target. ${ }^{30,31,36}$

Specifically for the mouth microbiota, Soukos et al. ${ }^{21}$ have shown that toluidine blue is cytotoxic to $S$. sobrinus in concentrations of $2.51 \mathrm{~g} / \mathrm{ml}$ after helium-neon laser energy dose $\left(547 \mathrm{~mJ} / \mathrm{cm}^{2}\right)$, while similar treatments did not affect the oral keratinocytes viability.

Although these experiments have shown to be efficient, they were done using lasers that are costly and may cause an eye damage risk to the patient as well as to the technician. ${ }^{37,38}$

The technique described in this article uses a light source of low cost and without UV-A or UV-B radiation, associated to a photosenstive dye (Rose Bengal) which shows a strong absorbance in the green region with a maximum of around $500 \mathrm{~nm}$ and a wide spectra (Fig. 1). Since it was observed that the dye has not altered it's absorbancy spectra in the presence of the cells ( $S$. mutans or fibroblasts), we might suggest that it's molecular structure was not altered and there is no agregation process which could reduce its efficiency in the ROS liberation after irradiation with the HHP.

The results obtained (Fig. 2) indicated that for both cells studied, the dye shows toxicity in the dark per se only in high concentrations (above $5.0 \mu \mathrm{M}$ ), which is normally found in exogenous photosensitive drugs. ${ }^{39}$ Studies performed by Chan and Lai, ${ }^{40}$ have demonstrated toxicity in the dark for the $S$. sanguis with $2 \times 10^{-4} \mathrm{M}$ of methylene blue while this same parameter for Rose Bengal over S. mutans was approximately 100 times higher. Nonetheless, doses of this order are not necessary for the experiments in the presence of light where lower doses take to bacterial cell death.

The difference between the dye concentrations which causes S. mutans death in the presence $(0.1 \mu \mathrm{M})$ and absence of light $(2 \mu \mathrm{M})$ clearly indicates that the compounds produced by the photoactivation of Rose Bengal are responsible for cellular death. Besides, under the established irradiation conditions, bacteria were 10 times more sensible to PDT than the fibroblasts which supposedly can be a reflex of the protection and repair systems in the eukaryotes like the superoxide dismutases enzymes present in the cytoplasm and mitochondria as well as some catalases. In addition to that, the presence of some metal-substituted poliene as beta-carotene and lycopene, besides vitamin E and $C,{ }^{41,42}$ many times absent in prokaryotes would work as anti free radical agents in the eukaryotes, providing a higher protection against reactive species generated by PDT.

Death of S. mutans induced after PDT was obtained also without previous incubation with the dye, demonstrating that the toxicity to these cells is probably due to reactive species produced in the extracellular media and not exclusively by the ones generated in the intracellular media (data not shown).

It is possible that Rose Bengal does not enter the bacterial cells as easily as human cells due to the presence of a cell wall and extracellular structures such as the capsule and slime layers. Besides that, the diffusion distance of reactive species yield is significantly small when compared to the cell size. This way, just as discussed by Zeina et al., ${ }^{43}$ the singlet oxygen formed in this system will not get primarily intracellular macromolecules such as DNA due to its low diffusion rate $(\leq 0.075 \mu \mathrm{m})$.

Due to the proximity of the bacteria present on the plaque and the cells present in the periodontal 
region, even with the possibility of isolating the area to be treated with PDT, the light dose is important, as well as the dye concentration, in order to inactivate only the bacteria. The results shown in Fig. 3 clearly demonstrate the photoinduced destruction of $\mathrm{S}$. mutans at the conditions used (above $216.6 \mathrm{~mJ} / \mathrm{cm}^{2}$ ), without cellular death of the fibroblasts.

Our methodology uses a visible light source (nonlaser), emitting approximately $300 \mathrm{~mJ} / \mathrm{cm}^{2}$ in the presence of $0.5 \mu \mathrm{g} / \mathrm{ml}$ of Rose Bengal to obtain a significant bacterial death. Comparatively, experiments done with PDT using laser light have demonstrated and efficient bactericide activity against $S$. sanguis using $2.5 \mu \mathrm{g} / \mathrm{ml}$ of Toluidine Blue with $500 \mathrm{~mJ} / \mathrm{cm}^{2} 21$ and $100 \mu \mathrm{g} / \mathrm{ml}$ of methylene blue with $900 \mathrm{~mJ} / \mathrm{cm}^{2}{ }^{40}$ Similar results were obtained also for Enterococcus seriolicida using $10 \mu \mathrm{g} / \mathrm{ml}$ of zinc phthalocyanine with $21.2 \mathrm{~J} / \mathrm{cm}^{2}$. ${ }^{44}$ These data shows that the system here proposed is efficient in generating ROS for killing S. mutans with low dye concentrations and similar light dose with non laser source. Others dyes, with different proprieties like absorption spectra, singlet quantum yield and solubility need be studied in PDT applications.

Therefore, in conformity with the purpose of this work, it is possible to have an efficient bactericide effect, especially if we consider the possibility of light filters change, and broadening the applicability of therapy (variation the spectra emission) to a wide variety of photosensitive dyes, producing a combination of broad-spectrum activity against dental pathogens and little or no act ivity against mammalian cells.

In conclusion, this paper reports the first use of HHP associated with PDT to inactivate S. mutans, a Gram positive bacteria. Our results show that this microorganism can be inactivated using $0.5 \mu \mathrm{M}$ of Rose Bengal, a xanthene dye, without damage to the fibroblasts in the same experimental conditions.

It is not suggested here that PDT will replace systemic antimicrobial chemotherapy, but improvements may be obtained using the photodynamic approach in clinical treatment, in addition to reduced side effects to the patient. However, more extensive experiments using Rose Bengal (also in gel suspensions) and others sensitizers given the toxicity of Rose Bengal, should be conducted both in vitro and in animal studies to develop a photochemotherapeutic system that would be suitable for clinical evaluation of its effectiveness.

\section{Acknowledgements}

We thank Priscila Cerviglieri for revision of the text manuscript. We also thank FAPESP and CNPq for the continuous support given to our laboratories. TPP is the recipient of a Ph.D. fellowship from CAPES. KFR is the recipient of an undergraduate fellowship from CNPq.

\section{References}

1. Krasse B. Caries risk: a pratical guide for a assessment and control. Chicago: Quintessence Publishing; 1985 p. 113.

2. Smith DJ. Dental caries vaccines: prospects and concerns. Crit Rev Oral Bid M 2002;13:335-49.

3. Marsh PD. Are dental diseases examples of ecological cata strophes? Microbiology 2003;149:279-94.

4. Radcliffe CE, Akram NC, Hurrel F, Drucker DB. Effects of nitrite and nitrate on the growth and acidogenicity of Streptococcus mutans. J Dent 2002;30:325-31.

5. Mikkelsen L, Jersen SB, Jakobsen J. Microbialstudieson plaque from carious and caries-free proximal tooth surfaces in a population withhigh caries experience. CariesRes 1981;15:428-35.

6. Chestnutt IG, MacFarlane TW, Aitchison TC, Stephen KW. Evaluation of the in vitro cariogenic potential of Streptococ. cus mutans strains isolated from 12-year old children with differing caries experience. Caries Res 1995;29:455-60.

7. Cox SD, Lassiter MO, Miller BS, Doyle RJ. A new mechanism of action of fluoride on streptococci. Blochem Biophys Acta $1999 ; 1428: 415-23$.

8. Hirasawa M, Takada K. Susceptibility of Streptococcus mutans and Streptococous sobrinus to cell wall inhibitors and development of a novel selective medium for $S$. sobrinus. Caries Res 2002;36:155-60.

9. Wallman C, Krasse B, Birkehed D, Diacono S. The effect of monitored chlorhexidine gel treatment on mutans strepto. cocci in margins of restorations. $J$ Dent 1998;26:25-30.

10. Malik Z, Ladan $\mathrm{H}$, Nitzan Y. Photodynamic inactivation of Gram-negative bacteria: problems and possible solutions. $J$ Photochem Photobiol B 1992;14:262-6.

11. Venezio FR, Di Vennerzo $C$, Sehrman $R$, Reichman $M$, Origitano T, Thompson K, et al. Bactericidal effects of photora diation therapy with hematoporphirin drivative. $J$ infect Dis 1985; 151:166-9.

12. Bertoloni $G$, Rossi $F$, Valduga $G$, Jori $G$, Ali $H$, van Lier JE. Photosensitizing activity of water- and lipid-soluble phtalocyanines on prokaryotic and eukaryotic microbial cells. Microblos 1992;71:33-46.

13. Smetana Z, Ben-Hur E, Mendetson E, Salsberg S, Wagner $P$, Malik $Z$. Herpes simplex virus proteins are damaged following photodynamic inactivation with phthalocyanines. $J$ Photochem Photobiol B 1998;44:77-83.

14. Matthews TD, Newman JT, Sangandares-Bernal F, Juddy MM, Chanh TC. Photodinamic ther apy of viral contaminants with potential for blood banking applications. Transfusion $1998 ; 28: 81-3$.

15. Bellnier B, Ho K, Pandey RK, Missert J, Dougherty TJ. Distribuition and elucidation of the tumor-localizing component of hematoporphyrin derivative in mice. Photochem Photobiol 1989;50:221-8.

16. Sharman WM, Allen CM, van Lier JE. Photodynamic therapeutics: basic principles and clinical applications. Drug dis. cov Today 1999;4:507-17.

17. Gomer CJ, Rucker N, Ferrario A, Wong S. Properties and applications of photodynamic therapy. Radiat Res 1989;120: $1-18$.

18. Henderson BW, Dougherty TJ. How does photodynamic therapy work? Photochem Photobiol 1992;55:145-57. 
19. Shawar R, Cooper BH. Comparative kinetics of hematoporphirin derivative uptake and susceptibility of Bacillus subtil is and Streptococcus faecalis to photodynamic action. Photochem Photobiol 1990;52:825-30.

20. Wilson M, Dobson J, Sarkar S. Sensitization of periodontophatogenic bacteria to killing by light from a low power lase. Oral Microbiol immun 1993;8:182-7.

21. Soukos NS, Wilson M, Burns T, Speight PM. Photodynamic effects of toluidine blue on human keratinocytes and fibroblasts and Streptococcus sanguis evaluated in vitro. Lasers Surg Med 1996;18:253-9.

22. Usacheva MN, Teichert MC, Biel MA. Comparison of the methylene blue and toluidine blue photobactericidal efficacy against Gram-positive and Gram-negative microrganisms. Lasers Surg Med 2001;29:165-73.

23. Burns T, Wilson M, Pearson GJ. Effect of dentine and collagen on the lethal photosensitization of Streptococcus mutans. Caries Res 1995;29:192-7.

24. Wood S, Nattress B, Kirkham J, Shore R, Brookes S, Griffiths J, et al. An in vitro study of the use photodynamic therapy for the treatment of natural oral plaque biofilms formed in vivo. $J$ Photochem Photobiol B 1999;50:1-7.

25. Rovaldi CR, Pievsky A, Sole NA, Friden PM, Rothstein DM, Spacciapoli P. Photoactive porphirin derivative with broad. spectrum activity against oral pathogens in vitro. Antimicrob Agents Ch 2000;44:3364-7.

26. Merchat $M$, Bertolini $G$, Giacomini P, Villanueva $A$, Jori $G$. Meso-substituted cationic porphyrins as efficient photosensitizers of Gram-positive and Gram-negative bacteria. $J$ Photochem Photobiol B 1996;32:153-7.

27. Stied H, Teuchner K, Paul A, Leupold D, Kochevar IE. Quantitative comparison of excited state propriet ies and intensity. dependent photosersitization by rose bengal. $J$ Photochem Photobiol B 1996;33:245-54.

28. Paczkowski J, Lamberts JJ, Paczkowska B, Neckers DC. Photophysical properties of rose bengal and its derivatives (XII). J Free Radic Blol Med 1985;1:341-51.

29. Wachter E, Dess C, Harkins J, Scott T, Peter sen M, Rush RE, et at. Pre-clinical evaluation of pharmacokinetics and safety. Lasers Surg Med 2003;32:101-10.

30. Dahl TA, Midden WR, Neckers DC. Comparison of photody. namic action by Rose Bengal in Gram-positive and Gramnegative bacteria. Photochem Photobid 1988;48:607-12.
31. Brancaleon L, Moseley H. Laser and non-laser light sources for photodynamic therapy. Lasers Med Sci 2002;17:173-86.

32. Satrom KD, Morris MA, Crigger LP. Potential retinal hazards of visible-light photopolymerization units. $J$ Dent Res $1987 ; 66: 731-6$.

33. Cook WD. Curing efficiency and ocular hazards of dental photopolymerization sources. Biomaterials 1986;7:449-54.

34. Paulino TP, Cardoso Jr M, Bruschi-Thedei GCM, Ciancaglini $P$, Thedei Jr G. Fermentable and non-fermentable sugars: a simple experiment of anaerobic metabolism. Biochem Mol Biol Educ 2003;31:180-4.

35. Kopac I, Batista U, CvetkoE, Marinon L. Viability of fibroblasts in cell culture after treatment with different chemical retraction agents. J Oral Rehabil 2002;29:98-104.

36. Wainwright $M$. Photodynamic antimicrobial chemotherapy (PACT). J Antimicrob Ch 1998;42:13-28.

37. Thach $\mathrm{AB}$. Laser injuries of the eye. int Ophthalmol Clin 1999;39:13-27.

38. Zoepf T, Jakobs R, Arnold JC, Apel D, Rosenbaun A, Riemann JF. Photodynamic therapy for palliation of nonresectable bile duct cancer-preliminary results with a new diode laser system. Am J Gastroenterol 2001;96:2093-7.

39. Tremblay JF, Dussalult S, Viau G, Gad F, Boushira M, Bissonn. ette R. Photodynamic therapy with toluidine blue in Jurkat cells: citotoxicity, subcellular localization and apoptosis induction. Photochem Photobid Sci 2002;1:852-6.

40. Chan T, Lai CH. Bactericidal effects of different laser wavelengths on periodontopathic germs in photodynamic therapy. Lasers Med Sci 2003;18:51-5.

41. Slupphaug G, Kavli B, Krokan HE. The interacting pathways for prevention and repair of oxidative DNA damage. Mutat Res 2003;531:231-51.

42. Mortensen A, Skibsted LH, Truscott TG. The interaction of dietary carotenoids with radical species. Arch Blochem Biophy 2001;385:13-9.

43. Zeina B, Greenma J, Corry D, Purcell WM. Antimicrobial photodynamic therapy: assessment of genotoxic effects on keratinocytes in vitro. Br J Dermatol 2003;148:229-32.

44. Minnock A, Vernon DI, Schofield J, Griffiths J, Zarish JH, Brown SB. Photoinactivation of bacteria. Use of a cationic water-soluble zinc phthalocyanine to photoinactivate both Gram-negative Gram-positive bacteria. J Photochem Photo. biol B 1996;32:159-64. 


\title{
Kinetic characterization of P-type membrane ATPase from Streptococcus mutans
}

\author{
Prislaine P. Magalhães ${ }^{\mathrm{a}}$, Tony P. Paulino ${ }^{\mathrm{a}}$, Geraldo Thedei Jr. ${ }^{\mathrm{b}}$, Pietro Ciancaglini, ${ }^{\mathrm{a}, *}$ \\ ${ }^{2}$ Faculdade de Flasofia Ciéncias e Letras de Ribeirão Preto-FFCLRP-USP, An Bandeirantes 3900, Departamento de Química, \\ 14040-901 Ribeirão Preto, SP, Brazil \\ Universidade de Uheraha, MG, Brazil
}

Received 12 May 2004; received in revised form 3 December 2004; accepted 10 December 2004

\section{Abstract}

The proton translocating membrane ATPase of oral streptococci has been implicated in cytoplasmatic pH regulation, acidurance and cariogenicity. Studies have confirmed that Streptococcus mutans is the most frequently detected species in dental caries. A P-type ATPase that can act together with $\mathrm{F}_{1} \mathrm{~F}_{\mathrm{o}}$-ATPase in $S$. mutans membrane has been recently described. The main objective of this work is to characterize the kinetic of ATP hydrolysis of this P-type ATPase. The optimum pH for ATP hydrolysis is around 6.0. The dependence of P-type ATPase activity on ATP concentration reveals high $\left(K_{0}=0.27 \mathrm{mM}\right)$ and low $\left(K_{0}=3.31 \mathrm{mM}\right)$ affinity sites for ATP, exhibiting positive cooperativity and a specific activity of about $74 \mathrm{U} / \mathrm{mg}$. Equimolar concentrations of ATP and magnesium ions display a behavior similar to that described for ATP concentration in $\mathrm{Mg}^{2+}$ saturating condition (high affinity site, $K_{0}=0.10 \mathrm{mM}$, and low affinity site, $K_{0 .}=2.12 \mathrm{mM}$ ), exhibiting positive cooperativity and a specific activity of about $68 \mathrm{U} / \mathrm{mg}$. Sodium, potassium, ammonium, calcium and magnesium ions stimulate the enzyme, showing a single saturation curve, all exhibiting positive cooperativities, whereas inhibition of ATPase activity is observed for zinc ions and EDTA. The kinetic characteristics reveal that this ATPase belongs to type IIIA, like the ones found in yeast and plants.

O 2004 Elsevier Inc. All rights reserved.

Keywards: Streptocacaus mutans; $\mathrm{H}^{+}$-ATPase; P-type ATPase; Oligomycin; Kinetic characterization

\section{Introduction}

Streptococcus mutans and other streptococci are of central importance for the formation of dental plaque and the establishment of conditions that can lead to the development of dental caries (Castilho et al., 2000). Dental caries is a multifactorial process, in which diet, the physical characteristics of the oral cavity, the $\mathrm{pH}$ of saliva and the types of microorganism present are all key determinants. Oral streptococci are the bacteria most frequently related to cariogenesis. Some streptococci are able to produce acids (acidogenesis), even at low $\mathrm{pH}$ values (aciduric capacity); grow in environments with an acidic $\mathrm{pH}$ (acidurance); and synthesize intra- and extracellular polysaccharides. Because all oral streptococci do not share these properties, cariogenic

* Corresponding author. Tel.: +5516602 3753; fax: +55 166338151 . E-mail address: pictro@ffclrp.usp.br (P. Ciancaglini).

1096-4959/\$ - see front matter 12004 Elsevier Inc. All rights reserved. doi:10.1016jj.cbpc.2004.12.007 potential varies among species. Several studies confirm a relationship between dental caries and the mutans group streptococci, particularly $S$. mutans and $S$. sobrinus (Quivey et al., 2000).

It is known that the ATPases located in the plasma membrane are responsible for cytoplasmatic proton extrusion and regulate the internal $\mathrm{pH}$. The $\mathrm{F}_{1} \mathrm{~F}_{\mathrm{o}}-\mathrm{ATP}$ ase is described as the main enzyme responsible for this translocation activity, and studies have shown that the ATPase activity present in $S$. mutans plasma membrane increases when this organism grows in an acidic environment (Belli and Marquis, 1991; Kobayashi, 2003).

The F-ATPase ATP synthase is present in the membranes of bacteria, chloroplasts and mitochondria. In microorganisms that possess a respiratory chain, the $\mathrm{F}_{1} \mathrm{~F}_{\mathrm{o}}$-ATPase synthesizes ATP (Sabbert et al., 1996). In contrast, anaerobic bacteria (for example $S$. mutans) that do not possess a respiratory chain produce ATP by glycolysis, 
which results in lactic acid production (Suzuki et al., 2000). In this kind of organism, $\mathrm{F}_{1} \mathrm{~F}_{0}-\mathrm{ATP}$ ase hydrolyzes ATP, resulting in the electrogenic extrusion of protons, which generates a proton-motive force (Hamilton and Bowden, 1996). Also, the membrane-bound $F_{1} F_{o}$-ATPase is thought to support the survival of anaerobic bacteria under low $\mathrm{pH}$ conditions (Kobayashi et al., 1984).

In contrast, plasma membranes of plants and yeasts have P-type $\mathrm{H}^{+}$-ATPase to maintain the intracellular $\mathrm{pH}$ and membrane potential. The P-type ATPases share the characteristic of having an aspartyl-phosphate intermediate state. A conserved aspartate (Asp ${ }^{378}$ in the Neurospora proton ATPase) is reversibly phosphorylated after the proton binds to the side of the membrane from the cytoplasmatic site. Aspartate phosphorylation results in a conformational change that reduces affinity of the binding site for the proton, which is then released to the outside (Auer et al., 1998; Kühlbrandt et al., 2002; Kühlbrandt, 2004).

P-type $\mathrm{H}^{+}$-ATPases are well known in yeasts and plants, and they are constituted by one polypeptide with a $100 \mathrm{kDa}$ chain (similar to the subunit $\alpha$ of $\mathrm{Na}, \mathrm{K}$-ATPase), with 10 transmembrane domains (Morsomme and Boutry, 2000). The $\mathrm{H}^{+}$-ATPase can be active as a monomer (Goormaghtigh et al., 1986), and when isolated from Neurospora crassa, this enzyme forms stable hexamers (Auer et al., 1998; Toyoshima et al., 2000; Rhee et al., 2002; Kühlbrandt, 2004). From the conservation of the amino acid sequences responsible for the nucleotide binding and autophosphorylation, it is thought that the basic mechanism for coupling of ion transport to ATP hydrolysis may be common throughout the P-type family. Three of the most studied members are referred to as $\mathrm{H}^{+}$-ATPase, $\mathrm{Na}^{+}, \mathrm{K}^{+}$-ATPase, or $\mathrm{Ca}^{2+}$-ATPase, according to their selectivity for the ions to be pumped (Rhee et al., 2002).

The P-type ATPase family is a large, physiologically important family of membrane proteins that can be divided into two major groups based on cation specificity. Members of the $\mathrm{P}_{1}$ group transport heavy metals, such as $\mathrm{Cu}^{2+}, \mathrm{Cd}^{2+}$, and $\mathrm{Hg}^{2+}$, while the members of the $\mathrm{P}_{2}$ group transport a wide array of monovalent and divalent cations, including $\mathrm{H}^{+}$, $\mathrm{Na}^{+}, \mathrm{K}^{+}, \mathrm{Mg}^{2+}$ and $\mathrm{Ca}^{2+}$. The KdpB-ATPase from Escherichia coli, which accumulates $\mathrm{K}^{+}$under conditions of potassium starvation, shares structural features with both groups and has been classified as a $\mathrm{P}_{3}$-ATPase. Screening of the Saccharomyces cerevisiae genome has revealed a total of

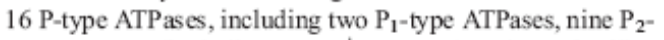
type ATPases (including two $\mathrm{H}^{+}$-ATPases) and two families of P-type ATPases called $\mathrm{P}_{4}$ and $\mathrm{P}_{5}$ (Lutsenko and Kaplan, 1995; Catty et al., 1997; Morsomme et al., 2000).

Based on the sequence homology of the P-type ATPase family, such family can be divided into five branches, which are referred to as types I-V. Within these branches, a total of 10 different subtypes or classes can be distinguished. The third branch Type, IIIA ATPases, are $\mathrm{H}^{+}$pumps that are found almost exclusively in the plasma membrane of plants and fungi. These ATPases are able to maintain an intra- cellular $\mathrm{pH}$ of $\sim 6.6$, against an extracellular $\mathrm{pH}$ of 3.5 , which corresponds to a membrane potential of $-180 \mathrm{mV}$ (Axelsen and Palmgren, 1998; Kühlbrandt, 2004).

The recently published genome sequence of $S$. mutans UA159 (Ajdic et al., 2002) shows a putative P-type ATPase (24379191 putative calcium transport P-type ATPase), which displays high homology to $\mathrm{H}^{+}$-ATPase of $N$. crassa (Blast Results: score $=222$ bits (566) Expect 3e-56, Magalhães et al., 2003). This possibility provides more convincing evidence that the proposed $\mathrm{H}^{+}$or $\mathrm{H}^{+}$, ion antiport ATPase could exist, working in association with $\mathrm{F}_{1} \mathrm{~F}_{\mathrm{o}}$-ATPase and extruding $\mathrm{H}^{+}$during these bacteria growth. Moreover, the complete sequence of the Streptococcus pneumoniae genome has shown the presence of $\mathrm{P}$ type ATPases, whose function is the transport of calcium, copper and metal/cation (Hoskins et al., 2001).

Specific inhibitors allow the classification of F-, V- and Ptype ATPases. In general, the ATPase activity of the membrane bound ATP synthase is inhibited by typical Ftype inhibitor such as oligomycin, which is a macrolide antibiotic that is well known as an inhibitor of the mitochondrial $\mathrm{H}^{+}$-ATPase (Homareda et al., 2000). P-types ATPases, on the other hand, are potently inhibited by orthovanadate, an analogue of the phosphate transition state, which binds to the cytoplasmic side of the system and requires magnesium for binding (Dafnis and Sabatini, 1994; Fedosova et al., 1998; Rice et al., 2001). V-type ATPases are commonly inhibited by nitrate and bafilomycin $\mathrm{A}_{1}$ (Hensel et al., 1996).

A preceding work (Magalhães et al., 2003) has described a $100 \mathrm{kDa}$ vanadate and lanzoprazole-sensitive ATPase from the $S$. mutans membrane, with a possible $\mathrm{H}^{+}$transport or $\mathrm{H}^{+}$/ion antiport activity that may be working in conjunction with the $\mathrm{F}_{1} \mathrm{~F}_{\mathrm{o}}$-ATPase, in the proportion of $60 \%$ and $40 \%$, respectively, on the regulation of cytoplasmic $\mathrm{pH}$ in this microorganism.

In this paper, we report the kinetic behavior of the membrane fraction $S$. mutans P-type ATPase and study which ions may be involved in the mechanism of this new enzyme. Such work significantly contributes to this area, since the majority of the work related to proton extrusion in this microorganism has been done with purified $\mathrm{F}_{1} \mathrm{~F}_{\mathrm{o}}=$ ATPase or with total membrane ATPase activity, where at least two proton ATPases are present ( $\mathrm{P}$ - and F-types).

\section{Materials and methods}

\subsection{Materials}

All solutions were prepared by using Millipore MilliQ ultra pure apyrogenic water. Tris[hydroxymethyl] aminomethane (Tris), bis [2-hydroxyethyl]imino-tris[hydroxymethyl]methane (BIS-TRIS), imidazole; trichloroacetic acid (TCA), lysozyme; 2- $N$-morpholine ethanesulfonic acid (MES), 2-amino-2-methyl-propan-1-ol (AMPOL), oligomy- 
cin, adenosine $5^{\prime}$-triphosphate Tris salt (ATP), sodium orthovanadate, lanzoprazole, protease inhibitor cocktail, deoxyribonuclease I (DNase I) and bovine serum albumin (BSA) were purchased from Sigma-Aldrich Chemical Co. Ethylenediaminetetraacetic acid (EDTA), $\mathrm{KCl}, \mathrm{NaCl}$, magnesium chloride, zinc chloride, calcium chloride and ammonium sulfate were purchased from Merck. Tryptic soy agar (TSA) was obtained from DIFCO. Analytical grade reagents were used without further purification.

\subsection{Strain}

The ATCC 25175 strain of $S$. mutans was purchased from the Fundação André Tosello, Campinas-SP (Brazil).

\subsection{Growth conditions}

S. mutans were kept stocked at $-20^{\circ} \mathrm{C}$, in $40 \%$ glycerol $(\mathrm{v} / \mathrm{v})$, or in a candle jar for frequent utilization upon weekly subculturing on TSA. Large amounts of cells were obtained from 1-L cultures of complete medium, described by Magalhães et al. (2003), grown until pH 4.2 (12 h of culture) in a candle jar and under magnetic stirring. Growth curves were constructed by inoculating $\sim 10^{7}$ cells $/ \mathrm{mL}$ in the complete medium. Samples were collected for $\mathrm{pH}$ and turbidity monitoring, and for the determination of membrane ATPase activity.

\subsection{Extraction of the ATPase membrane fraction}

The $\mathrm{H}^{+}$-ATPase rich membrane fractions were obtained as described by Magalhães et al. (2003). Briefly, approximately $1.0 \mathrm{~g}$ (wet mass) of cells were washed twice with 15 $\mathrm{mL}$ water and centrifuged at $9000 \times \mathrm{g}$, for $10 \mathrm{~min}$, at $20^{\circ} \mathrm{C}$. The pellet was weighed, resuspended and homogenized in $25 \mathrm{mM}$ MES, pH 6.2 buffer containing $97 \mathrm{mM} \mathrm{NaSCN}$. The absorbance (at $600 \mathrm{~nm}$ ) of the solution was monitored until it reached about 0.4 , and then it was homogenized. Lysozyme, $0.4 \mathrm{mg} / \mathrm{mL}$, was then added. The mixture was incubated for $3 \mathrm{~h}$, at $37{ }^{\circ} \mathrm{C}$, with gentle agitation, and centrifuged at $9000 \times \mathrm{g}$, for $20 \mathrm{~min}$, at $4{ }^{\circ} \mathrm{C}$. The pellet obtained was resuspended and homogenized in $50 \mathrm{mM}$ MES, pH 6.2 buffer containing $10 \mathrm{mM} \mathrm{MgSO}_{4}$ and $0.8 \mathrm{M}$ $\mathrm{NaCl}$ (osmotic buffer) and sonicated (tip sonicator, Vibracell $600 \mathrm{~V}, 50 \%$ amplitude) for $20 \mathrm{~min}$, at $4{ }^{\circ} \mathrm{C}(50 \mathrm{~mL}$ buffer $/ \mathrm{g}$ cell). The cell lyses was monitored by optical microscopy. The homogenate was incubated with gentle agitation for 45 $\mathrm{min}$, at room temperature, with $25 \mathrm{U}$ DNAse $/ \mathrm{mL}$ homogenate and $0.25 \mathrm{~mL}$ protease inhibitor cocktail $/ \mathrm{g}$ cell. The mixture was ultracentrifuged at $100,000 \times g$ for $1 \mathrm{~h}$, at $4{ }^{\circ} \mathrm{C}$. The pellet containing the membrane fraction was resuspended in $40 \mathrm{~mL}$ Tris- $\mathrm{HCl} 50 \mathrm{mM}, \mathrm{pH} 7.5$ buffer containing $10 \mathrm{mM} \mathrm{MgSO}_{4}$ (Stock Buffer) and re-ultracentrifuged in the same conditions describe above. The pellet containing the membrane fraction was resuspended in $40 \mathrm{~mL}$ of Stock Buffer and stored at $-80{ }^{\circ} \mathrm{C}$.

\subsection{Protein analysis}

Protein concentrations were estimated according to the Hartree method (Hartree, 1972), in the presence of $2 \%$ (w/ w) SDS, using BSA as standard.

\subsection{Enzyme assays}

ATPase activity was assayed discontinuously at $37^{\circ} \mathrm{C}$, by quantification of phosphate release as described by Heinonen and Lathi (1981). The reaction was initiated by the addition of the enzyme, stopped with $0.5 \mathrm{~mL}$ cold $30 \%$ TCA at appropriate time intervals, and centrifuged at $4000 \times g$ immediately prior to phosphate determination. Standard conditions were $50 \mathrm{mM}$ BIS-TRIS buffer, $\mathrm{pH}$ 6.0 , containing $5 \mathrm{mM} \mathrm{ATP}, 10 \mathrm{mM} \mathrm{MgCl} 2$ and $1 \mu \mathrm{g} / \mathrm{mL}$ of oligomycin as the F-type ATPase inhibitor. The ion effect was studied in a range of $10^{-6}$ to $10^{-1} \mathrm{M}$, always in the presence of $5 \mathrm{mM} \mathrm{ATP}$ and $10 \mathrm{mM} \mathrm{MgCl} 2$.

The activity determination was carried out in triplicate and the initial velocities were constant for at least $30 \mathrm{~min}$, provided that less than $5 \%$ of substrate was hydrolyzed. Controls without added enzyme were included in each experiment to quantify the non-enzymatic hydrolysis of the substrate. One enzyme unit (U) is defined as the amount of enzyme hydrolyzing $1.0 \mathrm{nmol}$ of substrate per min at $37^{\circ} \mathrm{C}$.

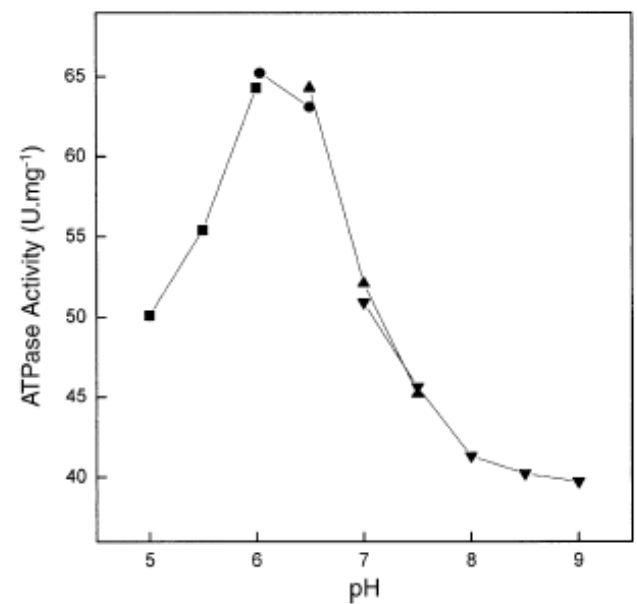

Fig. 1. Determination of optimum pH. ATP hydrolysis of P-type ATPase from $S$ mutans membrane fractions were assayed in reactional medium containing $10 \mathrm{mM}$ ATP, $5 \mathrm{mM} \mathrm{MgCl}$ and $1 \mu \mathrm{g} / \mathrm{mL}$ oligomycin, buffered

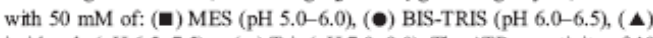
imidazole ( $\mathrm{pH} 6.5-7.5)$ or ( $\mathbf{v})$ Tris $(\mathrm{pH} 7.0-9.0)$. The ATPase activity of 40 $\mu \mathrm{g}$ total membrane protein was assayed discontinuously at $37^{\circ} \mathrm{C}$ by quantification of phosphate release. Data reported as the mean of triplicate measurement of different membrane preparations, which was considered to be statistically significant at $P \leq 0.05$. 


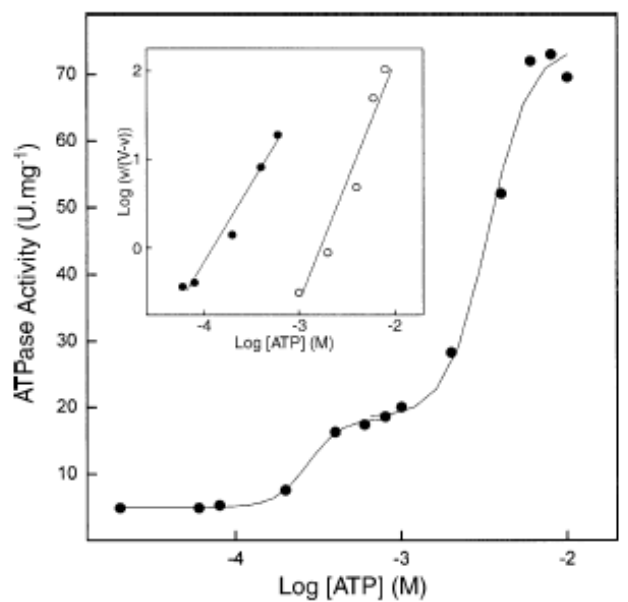

Fig. 2. Effect of increasing ATP concentrations on the plasma membrane P-type ATPase. Preparations were buffered with $50 \mathrm{mM}$ BIS-TRIS, pH 6.0, containing $10 \mathrm{mM} \mathrm{MgCl}$ and $1 \mu \mathrm{g} / \mathrm{mL}$ oligomycin. The reaction was started by addition of $40 \mu \mathrm{g}$ total membrane protein. Inset: Hill plot for the respective results $(\bullet)$, high affinity site and $(\mathrm{O})$ low affinity site. Each point represents the mean of triplicate measurements of different enzyme preparations, which was considered to be statistically significant at $P \leq 0.05$.

\section{7. pH sensitivity of catalysis}

The effect of $\mathrm{pH}$ on ATPase activity was measured in a $50 \mathrm{mM}$ buffer ranging from $\mathrm{pH} 5.0$ to 9.5 , containing $5 \mathrm{mM}$ ATP, $10 \mathrm{mM} \mathrm{MgCl} 2$ and $1 \mu \mathrm{g} / \mathrm{mL}$ of oligomycin. MES buffer was used in a range of $\mathrm{pH} 5.0$ to 6.0 , BIS-TRIS from $\mathrm{pH} 6.0$ to 6.5 ; imidazole from $\mathrm{pH} 6.5$ to 7.5 and Tris from $\mathrm{pH} 7.0$ to 9.0. The $\mathrm{pH}$ of the reaction mixture was measured both before and after the assay and did not vary by more than 0.05 units. ATPase activity was assayed as described above.

\subsection{Estimation of kinetic parameters}

Maximum velocity $\left(V_{\mathrm{M}}\right)$, initial velocity $(v)$, apparent dissociation constant $\left(K_{0.5}\right)$ and Hill coefficient $(n)$ obtained from substrate hydrolysis were calculated using the software described by Leone et al. (1992). Data are reported as the mean \pm S.D. of the triplicate measurement of different

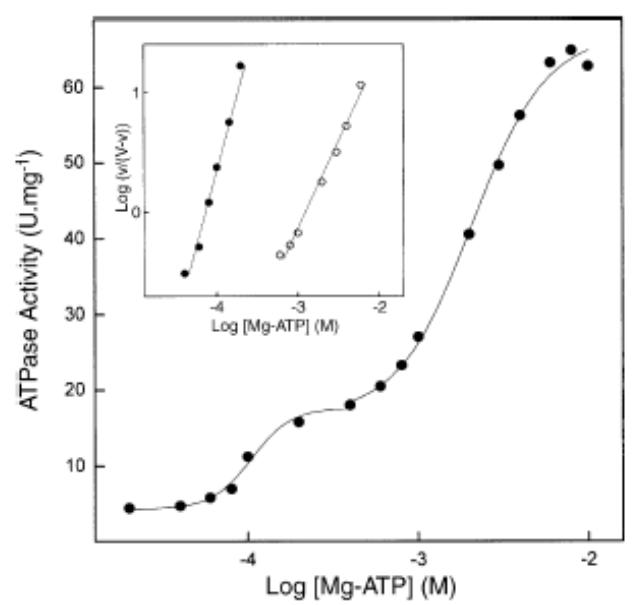

Fig. 3. Effect of increasing Mg-ATP concentrations on the plasma membrane P-type ATPase. Preparations were buffered with $50 \mathrm{mM}$ BISTRIS, $\mathrm{pH} 6.0$, containing $1 \mu \mathrm{g} / \mathrm{mL}$ oligomycin. The reaction was started by addition of $40 \mu \mathrm{g}$ total membrane protein. Inset: Hill plot for the respective results, $(\bullet)$ high affinity site and $(O)$ low affinity site. Each point represents the mean of triplicate measurements of different enzyme preparations, which was considered to be statistically significant at $P \leq 0.05$.

enzyme preparations, which was considered to be statistically significant at $P \leq 0.05$.

\section{Results}

The P-type ATPase present in membrane fractions was fairly stable, losing only $20 \%$ of its ATPase activity in 50 days when stored at $-20{ }^{\circ} \mathrm{C}$. Also, after sucrose gradient centrifugation (10-50\% continuous gradient) a single protein peak was revealed, with ATPase activity obtained in $15 \%$ sucrose (results not shown). All kinetic studies shown in this paper were performed in the presence of $1 \mu \mathrm{g} /$ $\mathrm{mL}$ oligomycin and the addition of vanadate $(3 \mu \mathrm{M})$ or Ianzoprazole $(50 \mu \mathrm{M})$ inhibited all P-type ATPase activity.

The optimum $\mathrm{pH}$ for ATP hydrolysis by the P-type ATPase present in the membrane fraction was around 6.0, as shown in Fig. 1. The effect of increasing ATP concentrations on the ATPase activity at $\mathrm{pH} 6.0$ (Fig. 2) revealed

Table 1

Kinetic parameters for the hydrolysis of ATP and Mg-ATP by plasma membrane P-type ATPase

\begin{tabular}{|c|c|c|c|c|c|c|}
\hline \multirow[t]{2}{*}{ Site affinity } & \multicolumn{3}{|l|}{ ATP } & \multicolumn{3}{|l|}{$\mathrm{Mg}$-ATP } \\
\hline & $K_{0.5}(\mathrm{mM})$ & $V_{\mathrm{M}}(\mathrm{U} / \mathrm{mg})$ & $n$ & $\mathrm{~K}_{0,5}(\mathrm{mM})$ & $V_{\mathrm{M}}(\mathrm{U} / \mathrm{mg})$ & $n$ \\
\hline High & $0.27 \pm 0.008$ & $18.3 \pm 0.4$ & 1.7 & $0.10 \pm 0.002$ & $17.4 \pm 0.5$ & $\overline{2.4}$ \\
\hline Low & $3.31 \pm 0.062$ & $73.8 \pm 1.5$ & 2.8 & $2.12 \pm 0.042$ & $67.6 \pm 2.4$ & 1.5 \\
\hline
\end{tabular}

Preparations were buffered with $50 \mathrm{mM}$ BIS-TRIS, $\mathrm{pH} 6.0$, containing $1 \mu \mathrm{g} / \mathrm{mL}$ oligomycin and different concentrations of ions as described in Materiak and methods. The reaction was started by the addition of $40 \mu \mathrm{g}$ total membrane protein. Data reported as the mean \pm S.D. of triplicate measurement of different enzyme preparations. 


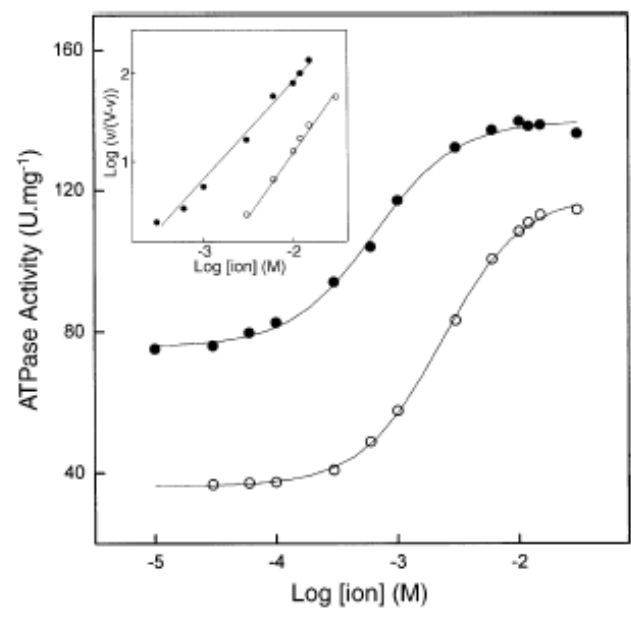

Fig. 4. Effect of $\mathrm{Ca}^{2+}$ and $\mathrm{Mg}^{2+}$ concentrations on the plasma membrane P-type ATPase. Preparations were buffered with $50 \mathrm{mM}$ BIS-TRIS, pH 6.0, containing $10 \mathrm{mM} \mathrm{MgCl}$ and $1 \mu \mathrm{g} / \mathrm{mL}$ oligomycin. The reaction was started by addition of $40 \mu \mathrm{g}$ total membrane protein. Inset: Hill plot for the respective results. (•) $\mathrm{Ca}^{2+}$ and $(\mathrm{O}) \mathrm{Mg}^{2+}$. Each point represents the mean of triplicate measurements of different enzyme preparations, which was considered to be statistically significant at $P \leq 0.05$.

two classes of hydrolyzing sites under the experimental conditions used (saturating $\mathrm{Mg}^{2+}$ conditions): high-affinity sites that correspond to about $25 \%$ of the total activity; and low-affinity sites that account for $75 \%$ of the total activity. Cooperative effects were found for both hydrolysis sites (Table 1). Excess ATP ( $>10 \mathrm{mM})$ also inhibited ATPase activity (results not shown).

Equimolar concentrations of ATP and magnesium ions showed similar behavior, as described in $\mathrm{Mg}^{2+}$ saturating condition (Fig. 3), and cooperative effects were also observed (Table 1). It is important to mention that inhibition of the ATPase activity was observed at high Mg-ATP concentrations (not shown).

Table 2

Kinetic parameters for stimulation of the ATPase activity of plasma membrane P-type ATPase by selected cations under different experimental conditions

\begin{tabular}{llrl}
\hline [lon] & \multicolumn{2}{l}{ Kinetic parameters } \\
\cline { 2 - 4 } & $K_{0 .}(\mathrm{mM})$ & $V_{\mathrm{M}}(\mathrm{U} / \mathrm{mg})$ & $n$ \\
\hline $\mathrm{Na}^{+}$ & $0.26 \pm 0.005$ & $96.8 \pm 1.6$ & 1.2 \\
$\mathrm{~K}^{+}$ & $0.21 \pm 0.003$ & $128.4 \pm 3.1$ & 1.8 \\
$\mathrm{NH}_{4}^{+}$ & $3.61 \pm 0.041$ & $115.5 \pm 3.7$ & 1.2 \\
$\mathrm{Ca}^{2+}$ & $0.62 \pm 0.013$ & $139.7 \pm 2.9$ & 1.1 \\
$\mathrm{Mg}^{2+}$ & $2.21 \pm 0.037$ & $116.7 \pm 2.5$ & 1.4 \\
\hline
\end{tabular}

Preparations were buffered with $50 \mathrm{mM}$ BIS-TRIS, $\mathrm{pH} 6.0$, containing 5 $\mathrm{mMATP}, 1 \mu \mathrm{g} / \mathrm{mL}$ oligomycin and varying the metallic ions as described in Materials and methods. The reaction was started by the addition of $40 \mu \mathrm{g}$ total membrane protein. Data reported as the mean \pm S.D. of triplicate measurement of different enzyme preparations.

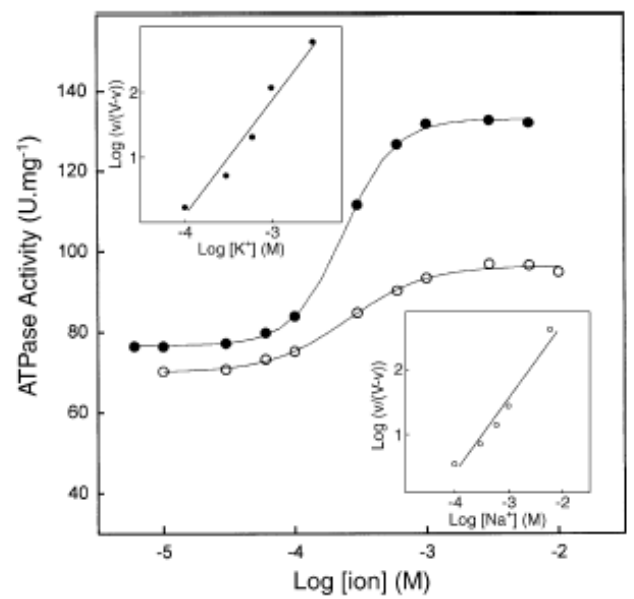

Fig. 5. Effect of $\mathrm{K}^{+}$and $\mathrm{Na}^{+}$concentrations on the plasma membrane P-type ATPase. Preparations were buffered with $50 \mathrm{mM}$ BIS-TRIS, $\mathrm{pH} 6.0$, containing $10 \mathrm{mM} \mathrm{MgCl}$ and $1 \mu \mathrm{g} / \mathrm{mL}$ oligomycin. The reaction was started by addition of $40 \mu \mathrm{g}$ total membrane protein. Inset: Hill plot for the respective results. (-) $\mathrm{K}^{+}$and $(\mathrm{O}) \mathrm{Na}^{+}$. Each point represents the mean of triplicate measurements of different enzyme preparations, which was considered to be statistically significant at $P \leq 0.05$.

The magnesium concentration dependence of the ATPase activity under saturating concentrations of ATP showed a single saturation curve (Fig. 4). Increasing magnesium ion concentrations from $0.1 \mathrm{mM}$ to $100 \mathrm{mM}$ stimulated ATPase activity to about $116 \mathrm{U} / \mathrm{mg}$, exhibiting cooperative effects

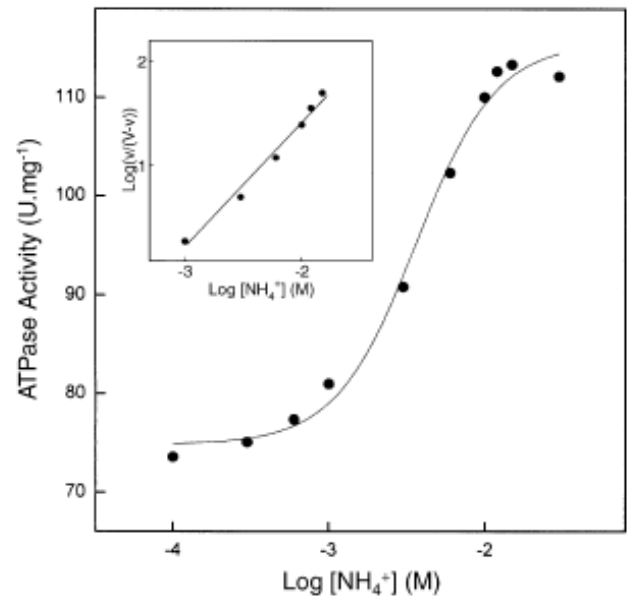

Fig. 6. Effect of $\mathrm{NH}_{4}^{+}$concentrations on the plasma membrane P-type ATPase. Preparations were buffered with $50 \mathrm{mM}$ BIS-TRIS, $\mathrm{pH} 6.0$, containing $10 \mathrm{mM} \mathrm{MgCl}$ and $1 \mu \mathrm{g} / \mathrm{mL}$ oligomycin. The reaction was started by addition of $40 \mu \mathrm{g}$ total membrane protein. Inset: Hill plot for the respective results. Each point represents the mean of triplicate measurements of different enzyme preparations, which was considered to be statistically significant at $P \leq 0.05$. 
( $n=1.4$, insert Fig. 4) with $K_{0.5}=2.2 \mathrm{mM}$ (Table 2). Excess magnesium ions inhibited ATPase activity (not shown). Fig. 4 also shows calcium concentration dependence of the ATPase activity under ATP $(5 \mathrm{mM})$ and $\mathrm{Mg}^{2+}(10 \mathrm{mM})$ saturating concentrations. Increasing calcium concentrations from $0.1 \mathrm{mM}$ to $100 \mathrm{mM}$ revealed a synergistic stimulation of ATPase activity to about $140 \mathrm{U} / \mathrm{mg}$, exhibiting cooperative effects ( $n=1.1$, insert Fig. 4) with $K_{0.5}=0.6 \mathrm{mM}$ (Table 2). Excess calcium ions inhibited ATPase activity (not shown).

The effect of potassium ions on the $S$. mutans P-type ATPase activity is shown in Fig. 5. Under ATP and $\mathrm{Mg}^{2+}$ saturating conditions, the ATPase activity was stimulated by potassium ions following a single saturation curve with $V_{\mathrm{M}}=128 \mathrm{U} / \mathrm{mg}$ and $K_{0.5}=0.21 \mathrm{mM}$, exhibiting a cooperative effect ( $n=1.8$, insert Fig. 5).

Under ATP and $\mathrm{Mg}^{2+}$ saturating concentrations, the Ptype ATPase activity was also stimulated by sodium ions (Fig. 5). Here, cooperative effects were observed and the hydrolysis followed a single saturation curve with $V_{\mathrm{M}}=97$ $\mathrm{U} / \mathrm{mg}$ and $K_{0.5}=0.26 \mathrm{mM}$ (Table 2).

The P-type ATPase was also stimulated by ammonium ions under ATP and $\mathrm{Mg}^{2+}$ saturating concentrations (Fig. 6), following a single saturation curve with $V_{\mathrm{M}}=115 \mathrm{U} / \mathrm{mg}$ and $K_{0.5}=3.6 \mathrm{mM}$, exhibiting a cooperative effect (insert Fig. 6 and Table 2).

Table 2 summarizes the kinetic parameters calculated for the stimulation of the ATPase activity of the membrane fraction of ATPase by all the studied ions. $\mathrm{Mn}^{2+}, \mathrm{Co}^{2+}$,

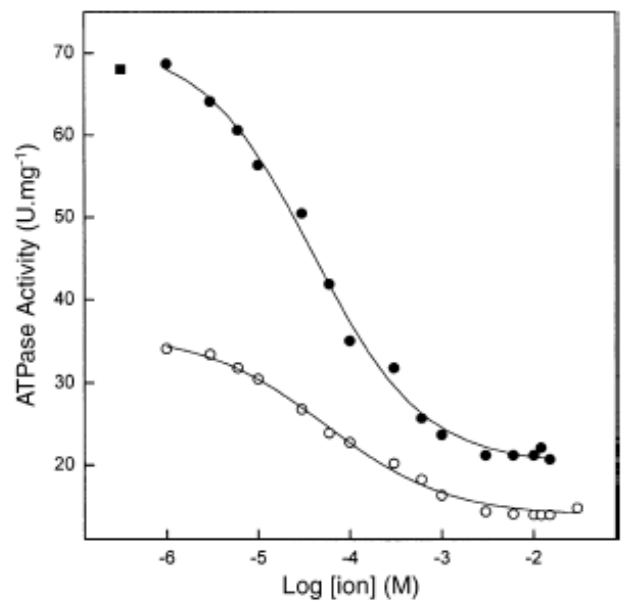

Fig. 7. Effect of $\mathrm{Zn}^{2+}$ and EDTA concentrations on the plasma membrane P-type ATPase. Preparations were buffered with $50 \mathrm{mM}$ BIS-TRIS, pH 6.0, containing $10 \mathrm{mM} \mathrm{MgCl}$ and $1 \mu \mathrm{g} / \mathrm{mL}$ oligomycin. The reaction was started by addition of $40 \mu \mathrm{g}$ total membrane protein. Inset: Hill plot for the respective results. (-) $\mathrm{Zn}^{2+}$ and (O) EDTA. (-) ATPase activity in reaction medium in the absence of $\mathrm{Zn}^{2+}$ and EDTA (Control). Each point represents the mean of triplicate measurements of different enzyme preparations, which was considered to be statistically significant at $P \leq 0.05$.
$\mathrm{Cd}^{2+}, \mathrm{Al}^{3+}, \mathrm{Cu}^{2+}$ and $\mathrm{Ni}^{2+}$ did not affect the ATPase activity (results not shown).

The effect of a wide range of zinc ion and EDTA concentrations on the P-type ATPase activity is shown in Fig. 7. Zinc ions exhibit single phase inhibitory behavior, with $K_{0.5}$ around $0.05 \mathrm{mM}$, progressively inhibiting all ATPase activity. EDTA inhibited most ATPase activity of the enzyme. A concentration of around $1 \mu \mathrm{M}$ was sufficient to inhibit approximately $65 \%$ of the activity. This inhibitor exhibited a single phase inhibitory behavior, with $K_{0.5}$ in the range of $0.1 \mathrm{mM}$.

\section{Discussion}

The literature concerning the proton extrusion in $S$. mutans is about the role of $\mathrm{F}_{1} \mathrm{~F}_{\mathrm{o}}$-ATPase, which extrudes $\mathrm{H}^{+}$, creates a transmembrane potential and keeps the intracellular $\mathrm{pH}$ around 6 , up to two units above the extracellular medium (Bender et al., 1986; Smith et al., 1996; Kuhnert and Quivey, 2003).

Studies of the plasma membrane ATPase activity of $S$. mutans strongly suggest the presence of another proton extrusion system. Suzuki et al. (2000) inhibited just $50 \%$ of the total $S$. mutans membrane ATPase activity using DCCD, a proton translocator inhibitor, and also showed that a mutant strain of $S$. mutans with only $50 \%$ of the total $\mathrm{F}_{1} \mathrm{~F}_{\mathrm{o}}-$ ATPase activity was able to grow and extrude protons, despite a delay in growth when compared to the wild strain. Magalhães et al. (2003) also described a membrane protein in $S$. mutans with a molecular mass of $100 \mathrm{kDa}$, which presented ATPase activity inhibited by classic inhibitors of P-type ATPases (orthovanadate) and $\mathrm{H}^{+}, \mathrm{K}^{+}$-ATPase (lanzoprazole). This enzyme had an optimum $\mathrm{pH}$, comparable to other $\mathrm{H}^{+}$-ATPases, and underwent phosphorylation and dimerization during the catalytic reaction, like the $\mathrm{H}^{+}$ATPases described in yeast and plant plasma membrane (Morsomme and Boutry, 2000).

In fact, the $S$ mutans UA159 genome showed the following P-type ATPases: ABC transporter, $\mathrm{Ca}^{2+}$-ATPase, $\mathrm{Cd}^{2+}$-ATPase, $\mathrm{Cu}^{2+}$-ATPase, $\mathrm{Al}^{3+}$-ATPase and a cation transporter ATPase. The ABC transporters did not display ATPase activity in $\mathrm{pH} 6.0$, as described by Ames et al. (2001), and the optimum $\mathrm{pH}$ for these enzymes was generally around 7.8-8.0, turning this activity improbable under the test conditions used in this manuscript. Also, Magalhães et al. (2003) showed small inhibition values for the ATPase activity of a membrane fraction for thapsigargin (5.6\%), a $\mathrm{Ca}^{2+}$-ATPase inhibitor. This suggests that the ATPase activity of a putative $\mathrm{Ca}^{2+}$-ATPase should represent only a small portion of the total ATPase activity of the membrane fraction obtained for the present methodology. Finally, the ion dependent ATPases hydrolyzed ATP in an ion-dependent manner. Since the employed reactional medium did not contain $\mathrm{Cd}^{2+}, \mathrm{Cu}^{2+}$ or $\mathrm{Al}^{3+}$, nor was the ATPase activity stimulated by these cations, it is improbable 
that the activity we described here is due to these iondependent ATPases.

It should be noted that many studies concerning the membrane-bound ATPase of $S$. mutans were done using the whole membrane, thus representing a sum of both F- and Ptype activities, except for the studies carried out with purified F-type ATPase (Sutton and Marquis, 1987).

In order to characterize a P-type activity, we performed all the experiments using $1 \mu \mathrm{g} / \mathrm{mL}$ oligomycin, inhibiting the F-type activity. Due to the lack of literature data on this activity (P-type) in bacteria, we used studies related to proton pumps of yeast and plants most of the time throughout the discussion.

The procedure usually used in the steady-state kinetic experiments to investigate the nature of the interaction between ligands and an enzyme consist of varying one ligand concentration at several fixed levels of the others. The comparison of kinetic parameters ( $V_{\mathrm{M}}$ and $K_{0.5}$ among others) is complex and requires suitable methodological control conditions, like tissue/protein isolation of the enzyme from the enzymatic assay $(\mathrm{pH}$, phosphate acceptor buffers, among others).

The optimum $\mathrm{pH}$ found for P-type $\mathrm{H}^{+}$-ATPase was 6.0, similar to that described for $N$. crassa and $S$. cerevisiae plasma membrane P-type $\mathrm{H}^{+}$-ATPase (Brooker and Slayman, 1982; Bowman and Bowman, 1986; Supply et al.,

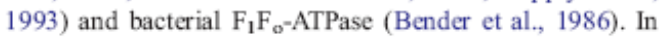
addition to that, Magalhães et al. (2003) showed optimum $\mathrm{pH}$ at about 6.5 , in $S$. mutans membrane fraction and sodium cholate-solubilized extract (for total ATPase activity).

The kinetic behavior of ATP hydrolysis by the P-type ATPase showed a biphasic curve for ATP hydrolysis with cooperative effect, suggesting the possibility of interaction between the subunits. In fact, the $S$ mutans ATPase described by Magalhães et al. (2003) may form a dimer of $200 \mathrm{kDa}$ during its catalytic cycle. This behavior is very common for P-type ATPases, such as plant $\mathrm{H}^{+}$-ATPase (Morsomme and Boutry, 2000) and mammals $\mathrm{Na}^{+}, \mathrm{K}^{+}$ATPase which showed a biphasic curve for ATP hydrolysis (Santos and Ciancaglini, 2003). On the other hand, $N$. crassa $\mathrm{H}^{+}$-ATPase showed "Michaelian" behavior, with $K_{\mathrm{M}}$ similar to the low affinity site for our enzyme, as shown in Table 1 (Smith and Hammes, 1988; Rao and Slayman, 1993).

The P-type ATPase was dependent on the presence of magnesium ions, (Fig. 4 and Table 2) exhibiting a single saturation curve, with a cooperative effect and $K_{0.5}$ a hundred times higher than that described for $N$. crassa $\mathrm{H}^{+}$ATPase. It should be stressed that this enzyme showed $\mathrm{Mg}^{2+}$-dependent-ATP inhibition and hydrolyzed ATP even in the absence of magnesium ions (Brooker and Slayman, 1983), whereas the Streptocoocus faecalis $\mathrm{K}^{+}$-ATPase lost about $90 \%$ of this ATPase activity in the absence of this ion (Hugentobler et al., 1983). The stimulation by equimolar concentrations of Mg-ATP (Fig. 3) was very similar to the stimulation of ATP in the presence of saturating magnesium ions concentration (Fig. 2 and Table 1). This behavior was very similar to other P-type ATPase, like mammalian $\mathrm{Na}^{+}, \mathrm{K}^{+}$-ATPase (Santos and Ciancaglini, 2003). Magnesium ions must have formed the Mg-ATP complex in solution, which is the true substrate used by the enzyme. It may also bound to a specific site on the P-type ATPase located in the cytoplasmatic domain, close to the ATP binding site (Scarborough, 2002). The strong inhibition of P-type ATPase by EDTA (Fig. 7) confirmed this hypothesis.

Except for the fact that the magnesium ions were indispensable for the ATPase activity, the P-type ATPase from $S$. mutans membrane did not show selectivity for the studied ions (Table 2 and Figs. 4-6), but it showed stimulation in the range of $50 \%$ to $100 \%$, except for zinc ions, which inhibited the ATPase activity (Fig. 7). Zine is a known inhibitor of acid production by mutans streptococci. It has been described that zinc, at concentrations as low as $0.01-0.1 \mathrm{mM}$, not only inhibited acid production by cells of $S$. mutans in suspension or in biofilms, but also sensitized glycolysis by intact cells to acidification (Phan et al., 2004).

Studies of streptococci membranes with total ATPase activity (P-type and F-type) showed strong inhibition of ATPase activity in the presence of divalent $\left(\mathrm{Ca}^{2+}, \mathrm{Zn}^{2+}\right.$, $\left.\mathrm{Sr}^{2+}, \mathrm{Ni}^{2+}, \mathrm{Mn}^{2+}, \mathrm{Cu}^{2+}\right)$ and monovalent $\left(\mathrm{K}^{+}, \mathrm{Na}^{+}\right)$cations (Sutton and Marquis, 1987; Rimpilainen, 1987). In contrast, S. mutans membrane P-type ATPase was activated by these cations (Table 2). Maybe these inhibitions were due to the Ftype ATPase present in this microorganism.

In $\mathrm{Na}^{+}, \mathrm{K}^{+}$-ATPase of vertebrate and crustacean, $\mathrm{NH}_{4}^{+}$can replace $\mathrm{K}^{+}$ions in sustaining the hydrolysis of ATP in the presence of $\mathrm{Mg}^{2+}$. There is also evidence that $\mathrm{NH}_{4}^{+}$ions can substitute $\mathrm{K}^{+}$ions in the transport of $\mathrm{Na}^{+}$ions by the membrane $\mathrm{Na}^{+}, \mathrm{K}^{+}$-ATPase (Wall, 1996; Masui et al., 2003). It is not reported that bacteria, plant and yeast proton ATPase is stimulated by ammonium ions. Since we observed a high stimulation for ammonium and potassium ions ( $70 \%$ and $89 \%$, respectively), it is possible that, for $\mathrm{P}$ type ATPase, the stimulation may happen through the mechanism described above.

For purified F-ATPase of $S$. mutans, $\mathrm{Ca}^{2+}$ and $\mathrm{Na}^{+}$ inhibited the relative activity in $72 \%$ and $96 \%$, respectively (Sutton and Marquis, 1987), whereas in S. mutans P-type ATPase, we could observe a stimulation of about $100 \%$ with $50 \mathrm{mM} \mathrm{CaCl}_{2}$ and $43 \%$ with $50 \mathrm{mM} \mathrm{NaCl}$ (Table 2, Figs. 4 and 5). These results suggest that unlike the F-type P-type is stimulated by calcium and sodium ions.

In spite of the lack of literature about proton transport independent of F-type ATPase in bacteria, many ion transporters were described in $S$. faecalis. A K $\mathrm{K}^{+}$-ATPase, strongly inhibited by vanadate $\left(I_{50}=3 \mu \mathrm{M}\right)$, with molecular mass of $78 \mathrm{kDa}$ was characterized (Fürst and Solioz, 1986). This enzyme showed a more alkaline optimum $\mathrm{pH}(7.3)$ and lower $K_{\mathrm{M}}$ for $\mathrm{Mg}$-ATP $(60 \mu \mathrm{M})$, when compared to $S$. mutans P-type ATPase. In addition to that, a $\mathrm{Ca}^{2+}$-ATPase also inhibited by vanadate, was studied both in intact bacterial cells and reconstituted in liposome (Ambudkar et 
al., 1986). Finally, a sodium/proton antiporter, dependent on proton-motive force was described as an alternative for $\mathrm{Na}^{+}$ extrusion in this organism when the $\mathrm{Na}^{+}$-ATPase was not induced (Kakinuma, 1987).

Hydrolysis mechanism of ATP for P-type ATPases pumps involve cycles between the $E_{1}$ and $E_{2}$ states, which have different binding affinities for nucleotides and for the transport ion. The $S$. mutans $\mathrm{P}$-type $\mathrm{H}^{+}$-ATPase may probably belongs to the type IIIA ATPases, like the ones found almost exclusively in the plasma membrane of plants and fungi. This group pumps protons out of the cell, creating a $\mathrm{pH}$ and electrochemical gradient that drives the $\mathrm{H}^{+}$-dependent co-transport of amino acids, sugars, and inorganic ions (Axelsen and Palmgren, 1998, Morsomme et al., 2000; Kühlbrandt, 2004).

The data presented in this work show that the ATPase characteristics are similar to the P-type ATPase already known $\left(\mathrm{H}^{+}\right.$-ATPase). The presence of cation-ATPase in $S$. mutans genome (Ajdic et al., 2002) strongly suggests that we detected a $S$. mutans $\mathrm{P}$-type $\mathrm{H}^{+}$- or $\mathrm{H}^{+}$,ion-ATPase that might act in association with $\mathrm{F}_{1} \mathrm{~F}_{0}$-ATPase during the growth of the bacteria, to eliminate intracellular $\mathrm{H}^{+}$ produced by the anaerobic metabolism of this organism. Since it was described that this P-type activity corresponds to $60 \%$ of the total ATPase activity in $S$. mutans membrane (Magalhães et al., 2003), its kinetic characteristics provided here can be used as reference values for a better understanding of the biochemical mechanisms of the acidurance in this organism.

\section{Acknowledgements}

We thank Priscila Cerviglieri and Cynthia M.C.P. Manso for revision of the manuscript. We also thank FAPESP, $\mathrm{CNPq}$ and UNIUBE for the continuous support given to our laboratories. PPM and TPP are the recipient of a $\mathrm{PhD}$ fellowship from CAPES.

\section{References}

Ajdic, D., McShan, W.M., McLaughlin, R.E., Savic, G., Chang, J., Carson, M.B., Primeaux, C., Tian, R., Kenton, S., Jia, H., Lin, S., Qian, Y., Li, S., Zhu, H., Najar, F., Lai, H., White, J., Roe, B.A., Ferretti, J.J., 2002. Genome sequence of Streptococetus mutans UA 159, a cariogenic dental pathogen. Proc. Nat. Acad. Sci. U. S. A. 99, 14434-14439.

Ambudkar, S.V., Lynn, A.R., Maloney, P.C., Rosen, B.P., 1986. Reconstitution of ATP-dependent calcium transport from streptococci. J. Biol. Chem. 261, 15596-15600.

Ames, G.F., Nikaido, K., Wang, L.X., Liu, P., Liu, C.E., Hu, C., 2001. Purification and characterization of the membrane-bound complex of an ABC transporter, the histidine permease. J. Bioenerg. Biomembr. 33, $79-92$.

Auer, M., Scarborough, G.A., Kühlbrandt, W., 1998. Three-dimensional map of the plasma membrane $\mathrm{H}^{+}$-ATPase in the open conformation. Nature 392, 840-843.

Axelsen, K.B., Palmgren, M.G., 1998. Evolution of substrate specificities in the P-type ATPase superfamily. J. Mol. Evol. 46, 84-101.
Belli, W.A., Marquis, R.E., 1991. Adaptation of Streptococcus mutans and Enterocacaus hirae to acid stress in continuous culture. Appl. Environ. Microbiol. 57, 1134-1138.

Bender, G.R., Sutton, S.V.W., Marquis, R.E., 1986. Acid tolerance, proton permeabilities, and membrane ATPases of oral streptococci. Infect. Immun. 53, 331-338.

Bowman, B.J., Bowman, E.J., 1986. $\mathrm{H}^{+}$-ATPases from mitochondria, plasma membranes and vacuoles of fungal cells. J. Membr. Chem. 94, $83-97$.

Brooker, R.J., Slayman, C.W., 1982. Inhibition of the plasma membrane $\left[\mathrm{H}^{+}\right]$-ATPase of Neumspora crassa by $\mathrm{N}$-ethylmaleimide. J. Biol. Chem. 257, 12051-12055.

Brooker, R.J., Slayman, C.W., 1983. Effocts of $\mathrm{Mg}^{2+}$ ions on the plasma membrane $\left[\mathrm{H}^{+}\right]$-ATPase of Neuraspara crassa: II. Kinetic studies. J. Biol. Chem. 258, 8833-8838.

Castilho, A., Rubiano, J., Gutiérrez, J., Hermoso, A., Liébana, J., 2000. Post-pH effect in oral streptococi. Clin. Microbiol. Infect. 6, $142-146$.

Catty, P., de Kerchove d'Exaerde, A., Goffeau, A., 1997. The complete inventory of the yeast Saccharonyces cerevisae P-type transport ATPases. FEBS Lett. 409, 325-332.

Dafnis, E., Sabatini, S., 1994. Biochemistry and pathophysiology of vanadium. Nephron $67,133-143$.

Fedosova, N.U., Cornclius, F., Klodos, L., 1998, E2 2 phosphoforms of $\mathrm{Na}, \mathrm{K}$-ATPase: I. Comparison of phosphointermediates formed from ATP and $\mathrm{Pi}$ by their reactivity toward hydroxylamine and vanadate. Biochemistry 37, 13634-13642.

Fürst, P., Solioz, M., 1986. The vanadate-sensitive ATPase of Streptocacaus faecalis pumps potassium in a reconstituted system. J. Biol. Chem. 261, $4302-4308$.

Goormaghtigh, E., Chadwick, C., Scarborough, G.A., 1986. Monomers of the Neurspora plasma membrane $\mathrm{H}^{+}$-ATPase catalyze efficient proton translocation. J. Biol. Chem. 261, 7466-7471.

Hamilton, I.R., Bowden, G.H.W., 1996. Fluoride effects on oral bacteria. In: Fejerskov, O., Ekstrand, J., Burt, B.A. (Eds.), Fluoride in dentistry, 2nd edition. Munksgaard Textbook, Copenhagen, pp. 230-251.

Hartre, E.F., 1972. Determination of proteins: a modification of the Lowry method that gives a lincar photometric response. Anal. Biochem. 48, $422-427$.

Heinonen, S.K., Lathi, RJ., 1981. A new and convenient colorimetric determination of inorganic orthophosphate and its application to the assay of inorganic pyrophosphatase. Anal. Biochem. 113, 313-317.

Hensel, M., Achmus, H., Deckers-Hebestreit, G., Altendorf, K., 1996. The ATP synthase of Streptomyces lividans: characterization and purification of the $\mathrm{F}_{1} \mathrm{~F}_{\mathrm{o}}$ complex. Biochim. Biophys. Acta 1274, $101-108$.

Homareda, H., Ishii, T., Takeyasu, K., 2000. Binding domain of oligomycin on $\mathrm{Na}^{+} \mathrm{K}^{+}$-ATPase. Eur. J. Pharmacol. 400, $177-183$.

Hoskins, J., Alborn, W.E., Amold, J., 2001. Genome of the bacterium Streptococaus pneumoniae strain R6. J. Bacteriol. 183, 5709-5717.

Hugentobler, G., Heid, I., Solioz, M., 1983. Purification of a putative K ${ }^{+}$ATPase from Streptococcus faecalis. J. Biol. Chem. 258, 7611-7617.

Kakinuma, Y., 1987. Sodium/proton antiporter in Streptotoccus faecalis. J. Bacteriol. 169, 3886-3890.

Kobayashi, H., 2003. Computer simulation of cytoplasmic pH regulation mediated by the F-type $\mathrm{H}^{+}$-ATPase. Biochim. Biophys. Acta 1607 , 211-216.

Kobayashi, H., Suzuki, T., Kinoshita, N., Unemoto, T., 1984. Amplification of the Streptococcus faecalis proton-translocating ATPase by a decrease in cytoplasmic pH. J. Bacteriol. 158, 1157-1160.

Kühlbrandt, W., 2004. Biology, structure and mochanism P-type ATPase. Nature 5, 282-295.

Kuhlbrandt, W., Zeekn, J., Dietrich, J., 2002. Structure, mechanism, and regulation of the Neturospora plasma membrane $\mathrm{H}^{+}$-ATPase. Science $297,1692-1696$.

Kuhnert, W.L., Quivey Jr., R.G., 2003. Genetic and biochemical characterization of the F-ATPase operon from Streptococcus sanguis 10904. J. Bacteriol. 185, 1525-1533. 
Leone, F.A., Degreve, L., Baranauskas, J.A., 1992. Sigraf-a versatik computer-program for fitting enzyme kinetic data. Biochem. Educ. 20, 94-96.

Lutsenko, S., Kaplan, J.H., 1995. Organization of P-type ATPases: significance of structural diversity. Biochemistry 34, 15607-15613.

Magalhães, P.P., Paulino, T.P., Thedei Jr., G., Larson, R.E., Ciancaglini, P., 2003. A $100 \mathrm{kDa}$ vanadate and lanzoprazole-sensitive ATPase from Streptococcus mutans membrane. Arch. Oral Biol. 48, 815-824.

Masui, D.C., Furriel, R.P.M., Mantelato, F.L.M., McNamara, J.C., Leone, F.A., 2003. Gill $\left(\mathrm{Na}^{+}, \mathrm{K}^{+}\right)$-ATPase from the blue crab Callinectes danae: modulation of $\mathrm{K}^{+}$-phosphatase activity by potassium and ammonium ions. Comp. Biochem. Physiol., B 134, 631-640.

Morsomme, P., Boutry, M., 2000. The plant plasma membrane H'-ATPase: structure, function and regulation. Biochim. Biophys. Acta 1465, 1-6.

Morsomme, P., Slayman, C.W., Goffean, A., 2000. Mutagenic study of the structure, function, and biogenesis of the yeast plasma membrane $\mathrm{H}^{+}$. ATPase. Biochim. Biophys. Acta 1469, 133-157.

Phan, T.N., Buckner, T., Sheng, J., Baldeck, J.D., Marquis, R.E., 2004. Physiologic actions of zinc related to inhibition of acid and alkal production by oral streptococci in suspensions and biofilms. Oral Microbiol. Immunol. 19, 31-38.

Quivey Jr., R.G., Kuhnert, W.L., Hahn, K., 2000. Adaptation of oral streptococi to low pH. Adv. Microb. Physiol. 42, 239-274.

Rao, R., Slayman, C.W., 1993. Mutagenesis of conserved residues in the phosphorylation domain of the yeast plasma membrane $\mathrm{H}^{+}$-ATPase. J. Biol. Chem. 268, 6708-6713.

Rhee, K., Scaraborough, A., Henderson, R., 2002. Domain movements of plasma membrane $\mathrm{H}^{+}$-ATPase: 3D structures of two states by electron cryo-microscopy. EMBO J. 21, 3582-3589.

Rice, WJ., Young, H.S., Martin, D.W., Sachs, J.R., Stokes, D.L., 2001. Structure of $\mathrm{Na}^{+}, \mathrm{K}^{+}$-ATPase at 11-A reso hution: comparison with $\mathrm{Ca}^{2+}$. ATPase in E1 and E2 states. Biophys. J. 80, 2187-2197.
Rimpilainen, M.A., 1987. Properties of the $N, N$-dicyclohexylcarboditmide resistant ATPase of Streptocaccus cremoris. Int. J. Biochem. 19, $729-732$.

Sabbert, D., Eng elbrecht, S., Junge, W., 1996. Intersubunit rotation in active F-ATPase. Nature 381, 623-625.

Santos, H.L., Ciancaglini, P., 2003. Kinetic characterization of Na,KATPase from rabbit outer renal medulla: properties of $(\alpha \beta)_{2}$ dimer. Comp. Biochem. Physiol., B 135, 539-549.

Scarborough, G.A., 2002. Molecular mechanism of the P-type ATPases. J. Bioenerg. Biomembr. 34, 235-250.

Smith, H.E., Hammes, G.G., 1988. Studies of the phosphoenzymo intermediate of the yeast plasma membrane proton-translocating ATPase. J. Biol. Chem. 263, 13774-13778.

Smith, A.J., Quivey, R.G., Faus toferri, R.C., 1996. Cloning and nucleotide sequence analysis of the Streptococcus mutans membrane-bound, proton-translocating ATPase operon. Gene 183, 87-96.

Supply, P., Wach, A., Goffean, A., 1993. Enzymatic properties of the PMA2 plasma membrane-bound $\mathrm{H}^{+}$-ATPase of Saccharomyces cerevisiae. J. Biol. Chem. 268, 19753-19759.

Sutton, S.V.W., Marquis, R.E., 1987. Membrane-associated and solubilized ATPases of Streptocaccus mutans and Streptocacas sanguis. J. Dent. Res. 66, 1095-1098.

Suzuki, T., Tagami, J., Hanada, N., 2000. Rok of $\mathrm{F}_{1} \mathrm{~F}_{\mathrm{o}}$-ATPase in the growth of Streptocaccus mutans GS5. J. Appl. Microbiol. 88, $555-562$.

Toyoshima, C., Nakasako, M., Nomura, H., Ogawa, H., 2000. Crystal structure of the calcium pump of sarooplasmic reticulum at $2.6 \mathrm{~A}$ resolution. Nature 405, 647-655.

Wall, S.M., 1996. Ammonium transport and the role of the Na, K-ATPase. Miner. Electrolyte Metab. 22, 311-317. 


\section{Laboratory Exercises}

\section{Use of Visible Light-based Photodynamic Therapy to Bacterial Photoinactivation}

Received for publication, April 19, 2004, and in revised form, August 23, 2004

Tony P. Paulinoł, Prislaine P. Magalhãesł, Geraldo Thedei, Jr.§, Antônio c. Tedescoł, and Pietro Ciancaglinifi

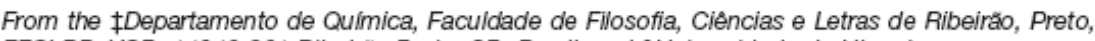
FFCLRP-USP, 14040-901 Ribeiráo Preto, SP, Brasil; and §Universidade de Uberaba, 38.055-500 Uberaba, MG, Brasil

The main focus of this laboratory exercise was to investigate the photodynamic therapy (PDT) acting over Streptococcus mutans. A handheld photopolymerizer and a classical photosensitizer (Rose Bengal) were used to induce photodynamic response. In this way, a suspension of $S$. mutans was treated with different concentrations of Rose Bengal $(0-10 \mu \mathrm{mol} / \mathrm{liter})$, irradiated with a light $(400-600 \mathrm{~nm})$ for $20 \mathrm{~s}$, and then cell viability was evaluated. It was observed that the light (per se) is not toxic, and in the dark, Rose Bengal is toxic only to the cells tested at concentrations above $5.0 \mu \mathrm{mol} /$ liter. Under light exposure, concentrations of Rose Bengal above $0.5 \mu \mathrm{mol} /$ liter killed all S. mutans. Therefore, for the purpose of our work, the photoactivation of Rose Bengal using the handheld photopolymerizer was efficient in bacteria inactivation.

Keywords: Handheld photopolymerizer, Streptococcus mutans, visible light, photodynamic therapy, Rose Bengal.

It has been estimated that the human body contains about $10^{14}$ cells, of which $90 \%$ are not mammalian. These cells comprise the microrganisms of the resident microflora of the host, which are not merely passive but contribute directly and indirectly to the normal development of the physiology, nutrition, and defense systems of the host. Many diseases are caused by microrganisms other than the resident ones and by unbalance of the resident [1].

An example of this unbalance occurs during the development of dental cavity, because the Gram-positive bacterium Streptococcus mutans is a substantial part of the cell microbiota present in the dental plaque subjected to the development of this disease. These bacteria use the carbohydrates present in the diet as an energy source, in an anaerobic process (mainly lactic fermentation) resulting in the production of organic acids [2]. These acids lower the $\mathrm{pH}$ to around 5.0 on the tooth surface [3], inducing its demineralization and causing dental cavity.

Dental cavity is among the most significant human chronic contagious diseases that affect primarily underdeveloped countries and low-income populations and/or immune-compromised patients $[1,4]$. The existence of the disease is due to several interacting factors that will produce the irreversible destruction of the mineralized structures of teeth, reaching considerable proportions of denta

If To whom correspondence should be addressed: Departamento de Química, Faculdade de Filosofia, Ciências e Letras de Ribeiräo, Preto, FFCLRP-USP, 14040-901 Ribeiräo Preto, SP Brasil. Tel.: 55-16-602-3753; Fax: 55-16-633-8151; E-mail: pietro@ffclrp.usp.br. vitality and of dental element fixation in the maxillomandibular complex [3].

Much effort has been done to control the bacterial proliferation in the mouth environment. Among them, vaccine production [5], fluoride therapy [6], and antibiotic therapy [7] are the most important.

In the present study, we show the use of a handheld photopolimerizer $(\mathrm{HHP})^{1}$ as a light source for bacterial inactivation after treatment with Rose Bengal in a simple demonstration of photodynamic therapy (PDT).

BACKGROUND THEORY AND PRELABORATORY PREPARATION

In the search for new strategies against microrganisms, studies using PDT have been routinely used in bacteria [8], yeast [9], virus [10], and human cell inactivation [11]

PDT is a therapy modality that employs the combination of visible light, a drug (called photosensitizer or dye), and molecular oxygen usually present in the tissue. This photosensitive agent can be a molecule normally present in cells and tissues, but in the specific case of PDT it is administered, this being the first step of the treatment. In the second step, the aimed tissue is exposed to a visible light at a specific wavelength that is absorbed by the photosensitive agent. The dye or light alone does not present cytotoxicity, at least not in the phototherapeutically active drug doses. Nevertheless, the combination of the two agents in the presence of oxygen leads to the

1 The abbreviations used are: HHP, handheld photopolimerizer; PDT, photodynamic therapy; ROS, reactive oxygen species; PBS, phosphate-buffered saline; TSB, tryptic soy broth; TSA, tryptic soy agar. 
production of different reactive oxygen species (ROS) such as singlet oxygen, ${ }^{1} \mathrm{O}_{2}$, among others, which will lead to a sequence of biological events resulting in the apoptosis of the cells or death of the microrganisms [12].

Although most PDT applications are associated with a laser light, nonlaser light sources have also been used. Studies developed in the last decade clearly indicate that the use of the visible-light isolated from a HHP unit (nonlaser light source) does not induce any thermal or photochemical damage to the retina [13]. In addition to that, the cost of use of HHP is lower than that of a laser light.

Studies using laser light irradiation indicate that certain bacteria can be efficiently inactivated after PDT with dyes as toluidine blue and methylene blue [14] or even with more complex molecules as dissulphonated phtalocyanin aluminum [15].

In PDT study, the xanthene-derivate Rose Bengal has been used as a model compound with excellent photophysical properties with a considerate absorption in the region of $500 \mathrm{~nm}$ and a good quantum yield of singlet oxygen production [16]. Although this dye is not approved for human use, it is used in the present work to show a PDT effect in a buccal bacterium S. mutans [17].

To perform this therapy against possible dental cavities and others infectious buccal diseases, gels or topical solutions should be used in the near future to promote the death of pathogens through photodynamic action, as well as the use of a FDA-approved dye.

\section{GENERAL NOTES}

In this class experiment, we describe a methodology adapted to the use of $S$. mutans, which can be acquired commercially. There is a possibility of isolating a lineage of S. mutans, inoculating a saliva sample in a selective culture medium mitis salivarius bacitracin sucrase [2]. Alternatively, another nonpathogenic microrganism could be used, because the conditions were standardized.

This class experiment does not use hazardous reagents, and the light source used was the HHP or dental photopolimerizer that generates visible light, reducing the risks involved with laser light utilization.

\section{EXPERIMENTAL PROCEDURES}

Hand Held Photopolimenizer-The HHP was purchased from Dabi Atlante SA (Ribeiräo Preto-SP, Brazil) and was used as the light source in all experiments. The HHP has $350-500 \mathrm{~mW} / \mathrm{cm}^{2}$ potency of light emitted at a wavelength range of $350-550 \mathrm{~nm}$.

Preparation of Stock Solution-Rose Bengal (Sigma, St. Louis, MO) was used as a stock solution, in phosphate-buffered saline (PBS; $\mathrm{NaCl} 0.13$ molliter, $\mathrm{KCl} 2.7 \mathrm{mmol} /$ liter, $\mathrm{Na}_{2} \mathrm{HPO}_{4} 8.1 \mathrm{mmol}$ liter, and $\mathrm{KH}_{2} \mathrm{PO}_{4} 1.47 \mathrm{mmol} /$ liter, final $\mathrm{pH} 7.4$ ), sterilized in a $0.22-\mu \mathrm{m}$ filter, at a concentration of $2 \mathrm{mmol} /$ liter. This solution was stored at $-20^{\circ} \mathrm{C}$.

Absorption Spectra of Dye-An absorption spectra (300-800 $\mathrm{nm}$ ) of a Rose Bengal stock solution ( $4.0 \mu \mathrm{mol} /$ liter in PBS) was performed in a spectrophotometer (Spectronic $\left(\right.$, Genesys $2^{\text {TM. }}$; Milton Roy, Spectronic Instrument, Inc., Rochester, NY) using a $1-\mathrm{cm}$ optical path cell at a $2-\mathrm{nm}$ reading interval.

Transmitance Spectra of HHP Light Filter-An absorption spectra $(300-800 \mathrm{~nm})$ of HHP filter was done in spectrophotometer (U-3000; Hitachi, Tokyo, Japan) with 2-nm reading intervals.

Strain -The American Type Culture Collection 25175 strain of

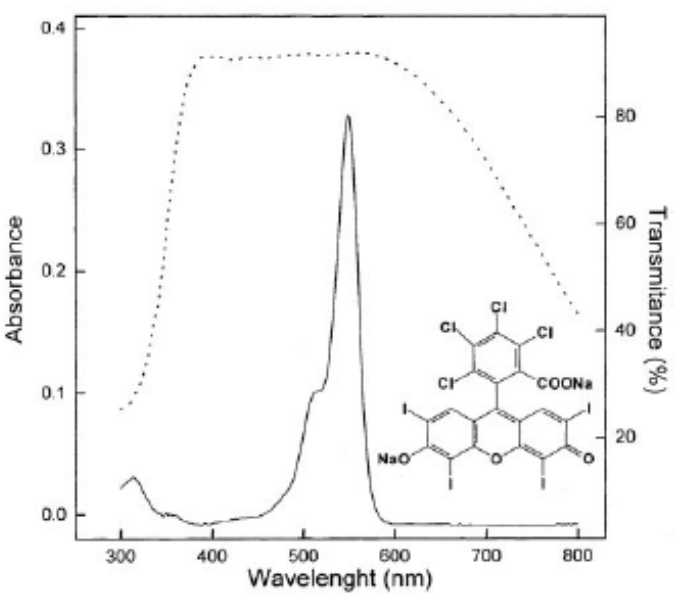

Fig. 1. Absorption spectra of $4.0 \mu \mathrm{mol} /$ liter Rose Bengal in PBS pH 7.4 (solid line) and transmittance spectra of HHP filter (dotted line). Inset, Rose Bengal structure.

S. mutans is available from the André Tosello Foundation (Campinas-SP, Brazil; wuw.bdt.fat.org.br). The lineage is stored in $-20^{\circ} \mathrm{C}$ in $40 \%$ (v/v) glycerol, and purity was checked prior to growth in broth.

S. mutans Growth Conditions-The media used to cultivate and check the cells viability was a tryptic soy broth (TSB, soybean-casein digest medium) or tryptic soy agar (TSA, soybeancasein digest agar) from Difco (Sparks, MD) prepared according to the manufacturer's instructions and autoclaved at $121^{\circ} \mathrm{C}$ during 15 min prior to use. All the cultivations were done in a candle jar, in a micro-aerophilic atmosphere, obtained after lighting a candle inside the jar to consume part of the oxygen. For microrganism assays, the initial turbidity of the bacteria culture was adjusted to $\mathrm{A} 600 \mathrm{~nm}=0.5\left(\sim 10^{9} \mathrm{cells} / \mathrm{ml}\right)$ using a spectrophotometer (Spectronic, Genesys 2; Milton Roy). Then, $15 \mu \mathrm{l}$ of the stock was inoculated in "Falcon tubes" $(15 \mathrm{ml})$ containing $4 \mathrm{ml}$ of previously autoclaved TSB medium. The initial number of colony forming units per milliliter (CFU/ml) was estimated by measuring the suspension turbidity with a spectrophotometer and verified by using CFU/ml count on TSA after anaerobic growth at $37^{\circ} \mathrm{C}$ for $36 \mathrm{~h}$ [2].

Effects of PDT in S. mutans-Before the incubation with different concentrations of Rose Bengal, the cells ( $A 600 \mathrm{~nm}=0.5$ ) were serially diluted in PBS to obtain a $10^{3} \mathrm{CFU} / \mathrm{ml}$ and distributed $(1 \mathrm{ml})$ in assay tubes $(125 \times 12 \mathrm{~mm})$. Following that, the dye was added to the cell suspensions (concentration range from 0 to $10 \mu \mathrm{mol} /$ liter) and, after $10 \mathrm{~min}$, submitted to light exposure ( $20 \mathrm{~s}$, $12.8 \mathrm{~mW}$ ) under gentle stirring. Light irradiation was done with the HHP tip $11 \mathrm{~cm}$ far from the bacterial suspension $(1 \mathrm{ml})$, which was kept under gentle stirring.

The growth of cells was done by dropping and spreading $50 \mu \mathrm{l}$ of cell suspension directly onto TSA, and incubating it protected from light) in a candle jar for $36 \mathrm{~h}$ at $37^{\circ} \mathrm{C}$. After this time interval, the colony forming units (CFU)/ $/ \mathrm{ml}$ were calculated.

The dye toxicity per se (in the dark) and the light toxicity per se (without dye) were performed as described above, only without light exposure or presence of dye, respectively.

Cell Disposa/-The cells that were not used or remained from the experiment were autoclaved at $121^{\circ} \mathrm{C}$ for $20 \mathrm{~min}$ and then discarded.

Student Pitfalls-This is a very easy class experiment, but some problems such as culture contamination may occur as a result of bad manipulation. 


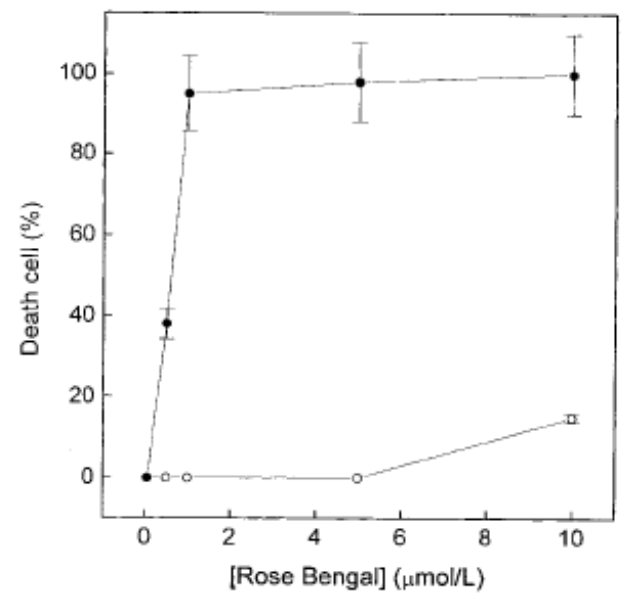

FIG. 2. S. mutans viability in the presence of variable concentrations of Rose Bengal. The bacteria $\left(10^{3} \mathrm{CFU}\right)$ was incubated with Rose Bengal for 10 min followed $(0)$ or not $(O)$ by light irradiation $\left(216.6 \mathrm{~mJ} / \mathrm{cm}^{2}\right)$ using a HHP and grown in TSA medium for $36 \mathrm{~h}$ in the dark.

\section{RESULTS AND DISCUSSION}

Fig. 1 shows the characteristic absorption spectra for a $4.0 \mu \mathrm{mol} /$ iter Rose Bengal PBS solution. It is worth to emphasize that this dye presents an absorption band in the range of $450-600 \mathrm{~nm}$, which is coincident with the emission spectra of HHP used (400-600 nm), suggesting that it is ideal to induce bactericidal effect over the cells and can be used to photoactivate the dye.

The Rose Bengal absorption spectra, obtained in the presence of $10^{3} \mathrm{CFU}$ of S. mutans, does not show any alteration, suggesting that its molecular structure wasn't altered and there is not any aggregation process that could reduce its efficiency in the ROS liberation after irradiation with the HHP (results not shown).

The results obtained (Fig. 2) in PDT experiments indicated that, for $S$. mutans, the dye shows toxicity in the dark per se only in high concentrations (above $5.0 \mu \mathrm{mol}$ liter), which is normally found in exogenous photosensitive drugs $[17,18]$.

Fig. 2 also shows that death induced by Rose Bengal treatment, followed by visible light irradiation $(216.6 \mathrm{~mJ} /$ $\mathrm{cm}^{2}$ ), is dose dependent for $S$. mutans. At $0.5 \mu \mathrm{mol} /$ iter Rose Bengal, $100 \%$ of cell death for $S$. mutans was observed. It was also observed that without Rose Bengal, light intensities up to $216.6 \mathrm{~mJ} / \mathrm{cm}^{2}$ did not affect the viability of the cells.

The great difference among the dye concentrations that cause S. mutans death in the presence $(0.5 \mu \mathrm{mol} /$ liter $)$ and absence of light (above $5 \mu \mathrm{mol} /$ liter) clearly indicates that the compounds produced by the photoactivation of Rose Bengal are responsible for cellular death.

The technique described in this experimental exercise uses a low-cost light source, without UV-A or UV-B radiation, it isn't dangerous, and should be available in all dentistry offices or dentistry school laboratories. Moreover, it uses as a experimental model an easily obtained microrganism. The sum of these factors contributes to the PDT use and demonstration. Also, with the use of HHP, it is possible to have an efficient bactericide treatment, especially if we consider the possibility of light filter change, widening the applicability of therapy (variation of the spectra emission) to a bigger variety of photosensitive dyes.

\section{LABORATORY TIME}

Our 1-year experience with different student classes shows that two periods of 2-3 h separated by a $48-\mathrm{h}$ interval are adequate to carry out the experiment as described. An assistant can prepare and autoclave the culture medium and inoculate it $12 \mathrm{~h}$ in advance.

In addition to this study, other dyes, light source, and irradiation times can be used. In this case, the laboratory time is proportionally increased.

\section{STUDY QUESTIONS}

1. What is the most important dye characteristic to be chosen as a photosensitizer compound?

2. Describe two PDT advantages against microbial agents.

3. What is necessary for an efficient photosensitization action to occur?

4. Is it possible for a photosensibilization action to occur in the absence of oxygen? Why?

5. What is the advantage of visible light and low-energy utilization in PDT?

6. What are the possible effects of ROS under the target cells in PDT?

7. What is the importance of dark toxicity and light toxicity per se in PDT efficacy studies?

Acknowledgments - We thank Priscila Cerviglieri for revision of the text manuscript. We also thank Fundação de Amparo à Pesquisa do Estado de Säo Paulo (FAPESP) and Conselho Nacional de Pesquisas (CNPq) for the continuous support given to our laboratories. TPP and PPM are the recipients of a Ph.D. fellowship from Comissäo de Aperfeiçaamento de Pessoal de Nivel Superior (CAPES).

\section{REFERENCES}

[1] P. D. Marsh (2003) Are dental diseases examples of ecological catastrophes? Microbiol. 149, 279-294.

[2] T. P. Paulino, M. Cardoso Jr., G. C. M. Bruschi-Thedei, P. Ciancaglini, G. Thedei Jr. (2003) Fermentable and non-fermentable sugars: A simple experiment of anaerobic metabolism, Biochem. Mol. Biol. Educ. 31, 180-184.

[3] C. E. Radcliffe, N. C. Akram, F. Hurrel, D. B. Drucker (2002) Effects of nitrite and nitrate on the growth and acidogenicity of Streptococcus mutans, J. Dent. 30, 325-331.

[4] B. Krasse (1985) Caries Risk: A Pratical Guide for a Assessment and Control. Quintessence Publishing. Chicago, IL, p. 113.

[5] D. J. Smith (2002) Dental caries vaccines: prospects and concems, Cit. Rev. Oral Biol. M. 13, 335-349.

[6] S. D. Cox, M. O. Lassiter, B. S. Miller, R. J. Doyle (1999) A new mechanism of action of fluoride on streptococci, Biochim. Biophys. Acta 1428, 415-423.

[7] M. Hirasawa, K. Takada (200e) Susceptibility of Streptococcus mutans and Streptococcus sobrinus to cell wall inhibitors and development of a novel selective medium for $S$. sobrinus, Caries Res. 36, $155-160$.

[8] F. R. Venezio, C. Di Vennerzo, R. Sehmman, M. Reichman, T. Origitano, K. Thompson, O. H. Reichman (1985) Bactericidal effects of photoradiation therapy with hematoporphirin drivative, J. Infect. Dis. 151, 166-169.

[9] G. Bertoloni, F. Rossi, G. Valduga, G. Jori, H. Ali, J. E. van Lier (1992) Photosensitizing activity of water- and lipid-soluble phtalocyanines on prokaryotic and eukaryotic microbial cells, Microbios. 71, 33-46. 
[10] Z. Smetana, E. Ben-Hur, E. Mendelson, S. Salsberg, P. Wagner, Z Malik (1998) Herpes simplex virus proteins are damaged following photodynamic inactivation with phthalocyanines, J. Photochem. Photobiol. B. 44, 77-83.

[11] N. B. R. Vittar, R. Galetto, E. I. Yslas, E. N. Durantini, V. Rivarola (2002) Promotion of photodynamic therapy-induced death, Biochem. Mol. Biol. Educ. 30, 303-305.

[12] W. M. Sharman, C. M. Allen, J. E. van Lier (1999) Photodynamic therapeutics: Basic principles and clinical applications, Drug Discov. Today 4, 507-517.
Toricles and clinical applications, Drug Discov.

[13] K. D. Satrom, M. A. Morris, L. P. Crigger (1987) Potential retinal hazards of visible-light photopolymerization units. J. Dent. Res. 66 , $731-736$.

[14] M. N. Usacheva, M. C. Teichert, M. A. Biel (2001) Comperison of the methylene blue and toluidine blue photobactericidal efficacy against
Gram-positive and Gram-negative microrganisms, Laser Surg. Med. 29, 165-173.

15] T. Bums, M. Wilson, G. J. Pearson. (1995) Effect of dentine and collagen on the lethal photosensitization of Streptococcus mutans, Caries Res. 29, 192-197.

[16] J. Paczkowski, J. J. Lamberts, B. Paczkowska, D. C. Neckers (1985) Photophysical properties of rose bengal and its derivatives (XII), $J$. Free Radic. Biol. Med. 1, 341-351.

[17] T. P. Paulino, K. F. Ribeiro, G. Thedei, A. C. Tedesco, P. Ciancaglini (2004) Use of hand held photopolymerizer to photoinactivate Streptococcus mutans, Arch. Oral Biol. 50, 355-361.

[18] J. F. Tremblay, S. Dussalult, G. Viau, F. Gad, M. Boushira, R. Bissonnette (2002) Photodynamic therapy with toluidine blue in Jurkat cells: Cytotoxicity, subcellular localization and apoptosis induction, Photochem. Photobiol. Sa. 1, 852-856. 


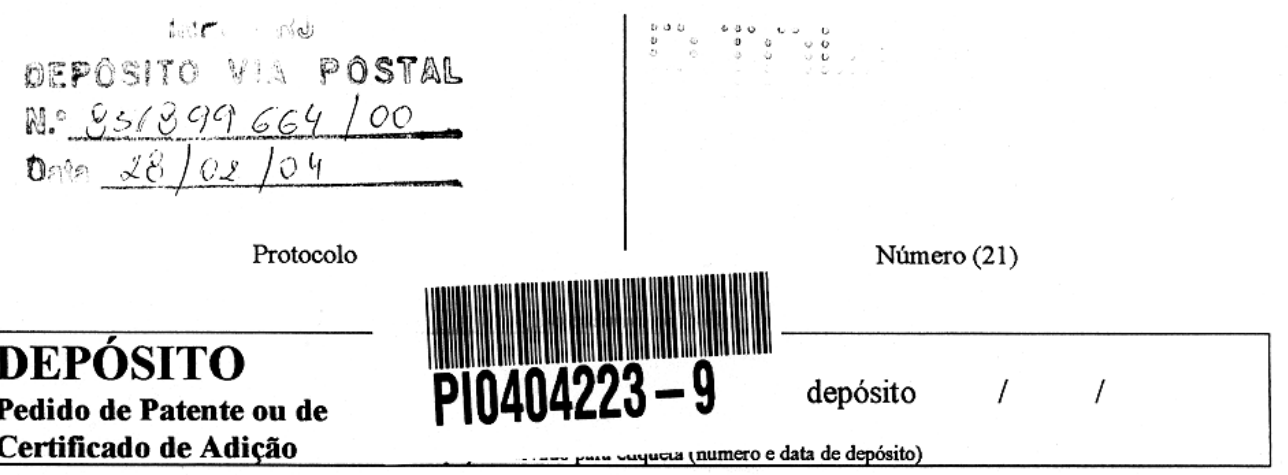

\section{Ao Instituto Nacional da Propriedade Industrial:}

O requerente solicita a concessão de uma patente na natureza e nas condições abaixo indicadas:

1. Depositante (71):

1.1 Nome: ANTONIO CLAUDIO TEDESCO

1.2 Qualificação: PROFESSOR DOUTOR 1.3 CGC/CPF: 076.231.908-90

1.4 Endereço completo: FFCLRP- USP, AV. DOS BANDEIRANTES, 3900 14.040-901 RIBEIRÃo PRETO - SP
1.5 Telefone:
(16) $-602-3751$
FAX:
(16) - 633-8151
$\bigotimes$ continua em folha anexa

\section{Natureza:}

\2.1 Invenção

2.1.1. Certificado de Adição

2.2 Modelo de Utilidade

Escreva, obrigatoriamente e por extenso, a Natureza desejada: INVENÇÃo

3. Título da Invenção, do Modelo de Utilidade ou do Certificado de Adição (54): USO DE AGENTES FOTO-SENSIVEIS NO.

$\bigotimes$ continua em folha anexa

4. Pedido de Divisão do pedido $\mathrm{n}^{\circ}$. , de .

5. Prioridade Interna - $O$ depositante reivindica a seguinte prioridade: $\mathrm{N}^{\circ}$ de depósito Data de Depósito

(66)

6. $\quad$ Prioridade - o depositante reivindica a(s) seguinte(s) prioridade(s):

\begin{tabular}{|l|l|l|}
\hline País ou organização de origem & Número do depósito & Data do depósito \\
\hline & & \\
\hline & & \\
\hline & & \\
\hline
\end{tabular}

continua em folha anexa

\footnotetext{
7. $\quad$ Inventor (72):
$\square \quad$ Assinale aqui se o(s) mesmo(s) requer(em) a não divulgação de seu(s) nome(s) (art. $6^{\circ} \S 4^{\circ}$ da LPI e item 1.1 do Ato Normativo $n^{\circ} 127 / 97$ )

7.1 Nome: ANTONIO CLAUDIO TEDESCO

7.2 Qualificação: PROFESSOR DOUTOR

Formulário 1.01 - Depósito de Pedido de Patente ou de Certificado de Adição (folha 1/2)
} 
Artigo submetido à Biochemistry and molecuylar biology education/2006

\section{Monitoring the acidogeny of Streptococcus mutans: The effect of carbon source and fluoride}

Tony P. Paulino ${ }^{\mathrm{a}}$, Maytê Bolean ${ }^{\mathrm{a}}$, Pietro Ciancaglini ${ }^{\mathrm{a}}$ and Geraldo Thedei Jr. ${ }^{\mathrm{b}^{*}}$

aa Departamento de Química, Faculdade de Filosofia, Ciências e Letras de Ribeirão Preto, FFCLRP-USP, 14040-901 Ribeirão Preto, SP, Brazil

${ }^{\mathrm{b}}$ Universidade de Uberaba, 38055-500 Uberaba, MG, Brazil

*Corresponding author

E-mail address: geraldo.thedei@uniube.br (G. Thedei)

Key words: Streptococcus mutans; carbon source, fluoride, acidogenesis 
Abstract

The main objective of this class experiment is to show the influence of the carbon source and fluoride on the acidogenic capability of Streptococcus mutans. Under the experimental condition of $50 \mathrm{mmol} / \mathrm{L}$ of fermentable carbohydrate, a decrease of 3 and $2 \mathrm{pH}$ units was observed in the absence or presence of $1 \mathrm{mmol} / \mathrm{L}$ fluoride, respectively. The great acidogenic capability and the velocity of acid production by this cariogenic bacterium allow an interesting discussion regarding the metabolic pathways which lead to cavity development. The influence of fluoride in acidogenesis reinforces the importance of this halogen in cavity prevention. In addition to that, the low execution cost and the simple technical apparatus makes this experiment easy to perform.

Key words: Streptococcus mutans; carbon source, fluoride, acidogenesis 


\section{INTRODUCTION}

The destruction of the mineralized structures of teeth is called "dental cavity". This process occurs basically by the action of acids produced by a variety of microorganisms which are normally present on tooth surface, forming an "oral microbiota" or "dental biofilm". Among the organisms found on biofilm, the Gram positive bacterium Streptococcus mutans stands out, recognized as one of the main caries-forming organisms and is a substantial part of the mouth cell microbiota [1].

The energy production by this organism is due to the anaerobic metabolism of carbohydrates, causing a $\mathrm{pH}$ drop on the dental surface and a consequent solubilization of the hydroxyapatite present at dental enamel, leading to dental cavity development [1].

There are two hypotheses for explain the acidification process. The most used one proposes that protons originate from glucose metabolism itself, during anaerobic fermentation process $[2,3,4]$. An alternative hypothesis postulates that hydrolysis of ATP without its regeneration através da oxidative phosphorilation generates the excess of protons, whereas anaerobic fermentation of glucose produces no net acid [5].

Sucrose is considered the most cariogenic of sugars, not only because of the fact it supplies highly fermentable monosaccharide (glucose and fructose), but also because it is the substrate of enzymes which produce polysaccharides that favor bacterial adhesion on dental surface forming a biofilm composed of different microorganisms [6].

Among the action mechanisms proposed for dental cavity reduction, the use of fluoride is prescribed due to the: inhibition of glycolitic enzyme enolase, reduction of cellular aggregation mediated by glucan-binding proteins [7,8], remineralization of acid-demineralized teeth and the formation of a less soluble dental component fluorhydroxyapatite [9].

The main objective of this experiment is to demonstrate the acid production by $S$. mutans metabolizing different sugars in the presence e absence of fluoride.

\section{BACKGROUND THEORY AND PRE-LABORATORY PREPARATION}

Through the 10 biochemical reactions of glycolysis, glucose is metabolized generating two molecules of pyruvate. This process reduces 2 moles of $\mathrm{NAD}^{+}$in 2 moles of NADH and generates a gain of 2 moles ATP per mol of glucose metabolized. As more and more glucose molecules are metabolized in this pathway, the $\mathrm{NAD}^{+}$stock becomes deprived and the regeneration of this molecule is necessary. To do this, the $\mathrm{NADH}$ may give their electrons to the respiratory chain (in aerobic organisms), a sequence of electron-transfer components which finally give the electron to its final acceptor oxygen. This process generates a high ATP yield and is used by so-called "aerobic organisms". Alternatively, NADH may donate its electrons to the pyruvate 
itself, in a process called fermentation [10] which is used by the so-called "anaerobic organisms".

Streptococcus mutans, like other cariogenic bacteria, are not able to synthesize cytocromes and do not carry out oxidative phosphorilation. This organism uses the carbohydrates present in the host's diet trough glycolytic pathway (Embden-MeyerhofParnas Pathway) leading to the production of pyruvate [11].

The pyruvate receives the electrons carried by $\mathrm{NADH}$ (regenerating $\mathrm{NAD}^{+}$) in an anaerobic process called "lactic fermentation", since this reaction forms mainly lactate but also acetate small amounts of formate, pyruvate, succinate and propionate $[12,13]$. All these anions formed inside the cell must be expelled to the external medium avoiding its accumulation in the cytoplasm.

Due to its great metabolic activity and to the presence of a proton pump that extrudes $\mathrm{H}^{+}$from cell interior in the direction of external medium, the environment surrounding the bacteria becomes acidified, leading to demineralization of tooth structures and, as a result, to cavity development $[14,15,16]$.

The fermentation process is blocked in the presence of fluoride by at least two ways, both related with the inhibition of the enzyme enolase, the $9^{\text {th }}$ enzyme of the glycolytic pathway: (i) enolase converts 2-phosphoglycerate and ADP into phosphoenolpyruvate (PEP) and ATP, avoiding ATP production and (ii) the glucose uptake is reduced because one of the systems for absorption of this sugar in streptococci involves PEP, thus depriving the cell of glucose and, consequently, of energy. The combination of these effects may be related to the reported beneficial effects of fluoride in oral health [9].

The simple experiment proposed here allows the discussion of essential aspects of $S$. mutans sugar metabolism and its effects over acidification of extracellular medium and the possible consequent tooth demineralization. The effect of fluoride gives light to the important role of this halogen in dental cavity prevention.

\section{GENERAL NOTES}

In this class experiment, we describe a methodology adapted to the use of a $S$. mutans strain acquired commercially. There is a possibility of isolating a lineage of $S$. mutans, inoculating a saliva sample in Mitis-Salivarius-Bacitracin-Sucrose (MSBS), a selective culture medium [17].

EXPERIMENTAL PROCEDURE 
Strain: The ATCC 25175 strain of Streptococcus mutans is available from the André Tosello Foundation, Campinas-SP (Brazil) http://www.bdt.fat.org.br/. The lineage was stored in $-20^{\circ} \mathrm{C}$ in $40 \%$ (v/v) glycerol.

Liquid medium: The complete medium described by Dhasper and Reynolds [17] was used as described [18]. This medium was composed by $10 \mathrm{~g} / \mathrm{L}$ triptone; $5 \mathrm{~g} / \mathrm{L}$ Yeast extract; $60 \mu \mathrm{mol} / \mathrm{L} \mathrm{MgSO}_{4} ; 1.3 \mu \mathrm{mol} / \mathrm{L} \mathrm{FeSO}_{4} ; 1.5 \mu \mathrm{mol} / \mathrm{L} \quad \mathrm{MnCl}_{2} ; 0.2 \mu \mathrm{mmol} / \mathrm{L}$ $\mathrm{KH}_{2} \mathrm{PO}_{4} ; 0.3 \mathrm{mmol} / \mathrm{L} \mathrm{K}_{2} \mathrm{HPO}_{4} ; 0.7 \mathrm{mmol} / \mathrm{L} \mathrm{KCl}$ and autoclaved at $121^{\circ} \mathrm{C}$ during 15 $\min$.

Sugars solutions: Each stock sugar solution (glucose, xylose, sucrose, fructose), used to complement the complete culture medium was prepared at a final concentration of 2 $\mathrm{mol} / \mathrm{L}$ and autoclaved at $121^{\circ} \mathrm{C}$ for $15 \mathrm{~min}$. Maltose stock solution was $1 \mathrm{~mol} / \mathrm{L}$, autoclaved under the same condition.

Growth conditions: All cultivations were done in a candle jar, at $37^{\circ} \mathrm{C}$ for 24 hours, in a micro-aerophilic atmosphere obtained after lighting a candle inside the jar and tampar a jarra hermeticamente to consume part of the oxygen and avoid entrada de fresh air. This is a simple way to consume part of oxygen present in the environment, creating an ideal atmosphere to the S. mutans growth.

Pre-inoculate: Stock strain was submitted to 3 successive transferences (12 hours incubation) in Tryptic Soy Broth (TSB) medium in order to reestablish their normal metabolism. The turbidity of the pre-inoculate was adjusted to $\mathrm{A}_{600 \mathrm{~nm}}=0.5$, corresponding to $\sim 10^{9}$ cells $/ \mathrm{mL}$ (for details see reference $[18,19]$ and the inoculate in $100 \mathrm{~mL}$ liquid medium supplemented with glucose as carbon source. The cells were then submitted to overnight incubation as described above.

Carbohydrate pulse: After overnight growth, the cells were harvested by centrifugation at room temperature and washed with $10 \mathrm{~mL}$ of $50 \mathrm{mmol} / \mathrm{L} \mathrm{KCl}$ containing $1 \mathrm{mmol} / \mathrm{L}$ $\mathrm{MgCl}_{2}$. The cells were suspended in the same solution and the absorbance was adjusted to 1 and the $\mathrm{pH}$ to 7.3 using $0.5 \mathrm{~mol} / \mathrm{L} \mathrm{KOH}$. To $10 \mathrm{~mL}$ of the cell suspension, the volume of carbohydrate enough to $50 \mathrm{mmol} / \mathrm{L}$ final concentration was added and the $\mathrm{pH}$ 
was monitored during at least 2 hours. During this time, the incubation was kept at room temperature and slow stirring.

Cell disposal: The cells which were not used or remained from the experiment were autoclaved at $121^{\circ} \mathrm{C}$ for 20 minutes and then discarded.

\section{STUDENT PITFALLS}

This is a very easy class experiment, but some problems, such as culture contamination, may occur as a result of bad manipulation.

Adjusting the $\mathrm{pH}$ of the cell suspension to 7.3 is time consuming, since the cell suspension can drop the $\mathrm{pH}$ strongly. The addition of $0.5 \mathrm{~mol} / \mathrm{L} \mathrm{KOH}$ solution should be drop to drop, in order to avoid excessive alkalinization of the cell suspension.

\section{RESULTS AND DISCUSSION}

Figure 1 shows the decrease in $\mathrm{pH}$ after the addition of different sugars to a cell suspension of $S$. mutans. An intense and very similar $\mathrm{pH}$ decrease can be observed until the 20 initial minutes of incubation with glucose, fructose, maltose and sucrose. After this initial and intensive acid liberation, a phase of slow $\mathrm{pH}$ decrease is observed, continuing until 120 minutes of incubation. This decrease in $\mathrm{pH}$ is due, as described above, to sugar metabolization through glycolytic pathway with subsequent production of organic acids which makes the environment acidic, as already observed in culture medium [19].

When xylose is the carbon source, the acidification is less intense and reaches a similar value to that of the control without carbohydrate addition. Since it was already described that xylose does not promote the growth of $S$ mutans [19], the initial acidification may occur due to one alternative mechanism of sugar uptake by this organism, which involves the antiport with $\mathrm{H}^{+}$[20]. Since xylose may not be metabolized by the bacterium, the energy production soon decreases and the acidification stops. In fact, in the absence of metabolic fuel, the $\mathrm{pH}$ decreases uniformly and reaches values similar to that observed in the pulse with xylose (Figure 1). This reinforces the observation of Paulino et al. [19], where growth and acidification in media without the addition of carbohydrate are insignificant, possibly because the fermentable sugar is restricted to the intracellular reserves, as already described [21]. These reserves would be enough to start the acidification, but they would soon be 
depleted. So, the $\mathrm{pH}$ decrease in the control and xylose experiments is due to the elimination of acid produced through the metabolization of intracellular reserves of fuel, probably polysaccharides [22].

This experiment also shows us that sucrose is not more acidogenic than glucose or fructose, since it induces a similar acidification of extacellular environment. The cariogenicity of this sugar is related with the induction of the synthesis of extracellular polysaccharides evolved with bacterial adhesion on tooth surface and consequent biofilm formation, as described by Rola [6].

Figure 2 shows the results of a carbohydrate pulse in the presence of $1 \mathrm{mmol} / \mathrm{L}$ fluoride. It may be observed that fluoride affects negatively the acidogenic capacity of S. mutans for all metabolized sugars. This may be due, at least in part, to the known inhibition of enolase by fluoride. The inhibition of this enzyme leads to block glycolysis and the subsequent acid production, explaining the small acidification. Since xylose is not metabolized by $S$. mutans, the fluoride has no effect on acid production when this sugar is the carbon source. Besides that, this ion can also interfere in the use of intracellular reserves (intracellular glycogen) since in the cell suspension supplemented with fluoride there is a smaller acidification than the one observed in its absence.

Fluoride may also affect the glucose absorption, since glucose (and many other sugars) is transported through the phosphoenolpyruvate (PEP)-dependent sugar phosphotransferase system (PTS), o qual depende da presence de phosphoenolpyruvate. Uma vez que a inhibition of enolase blocks the production of phosphoenolpyruvate, this result in a reduction of PTS activity [9].

In addition, fluoride can inhibit the proton translocating F-type ATPase of streptococcal cell membranes, causing a deleterious intracellular $\mathrm{pH}$ drop [2].

In conclusion, this class experiment shows that $S$. mutans is able of intensive acid production, as long as the carbon sources are metabolized by the organism, leading to an elevated risk of dental cavity development of the host due to the acid-induced tooth demineralization. Opposed to common sense, this risk appears soon after carbohydrate reaches the bacterium and not after many hours wit hout tooth hygiene, since it was observed that the major acidification occurs after the 20 initial minutes of incubation in the presence of metabolized sugars. In other words, the demineralization of tooth begins soon after carbohydrate consumption, so mouth hygiene should be done fast. Better results are expected if hygiene contains fluoride, because acidogenesis is significantly affected by this halogen, possibly by the blockage of the glycolytic 
activity.

\section{LABORATORY TIME}

Our experience with different student classes shows that 1 period of 4 hours separated by an overnight interval is adequate to carry out the experiment as described. An assistant can prepare and autoclave the culture medium, prepare the pre-inoculate and adjust the $\mathrm{pH}$ of cell suspension in advance, leaving to the students the pulse of carbohydrates and $\mathrm{pH}$ measurement.

\section{Acknowledgements}

We thank Priscila Cerviglieri for revision of the manuscript. We also thank FAPESP, CNPq, CAPES and Universidade de Uberaba, for the continuous support given to our laboratories. TPP is the recipient of a Ph.D. fellowship from CAPES

\section{STUDY QUESTIONS}

1) Why can $S$. mutans induce cavity formation?

2) Why does enolase inhibition decrease the acidification of the incubation medium?

3) How is glucose transformed into lactic acid, by lactic fermentation?

4) Is sucrose more acidogenic than glucose or fructose?

5) If the previous answer is "no", why is sucrose more cariogenic than other sugars?

6) If tooth hygiene is done 30 minutes after ingestion of a sucrose-containing food, is there any risk of dental cavity?

\section{REFERENCES}

[1] W. J. Loesche (1986) Role of Streptococcus mutans in human dental decay. Microbiol. Rev. 50, 353-380.

[2] S.V.W. Sutton and R. E. Marquis (1987) Membrane-associated and solubilized ATPases of Streptococcus mutans and Streptococcus sanguis. J. Dent. Res. 66(6): $1095-1098$

[3] S. Hamada and H.D. Slade (1980) Biology, immunology and cariogenicity of Streptococcus mutans. Microbiol. Rev. 44:331-384;

[4] J. van Houte (1986) Bacterial specificity in the etiology of caries. Int. Dent. J. 30:305-326

[5] R. A. Robergs, F. Ghiasvand and D. Parker (2004) Biochemistry of exercise-induced metabolic acidosis. Am. J. Physiol. Regul. Integr. Comp. Physiol. 287: R502-R516.

[6] G. Rolla (1989) Why is sucrose so cariogenic? The role of glucosyltransferase and polysaccharides. Scand. J. Dent. Res. 97(2): 115-119.

[7] S. D. Cox, M. O. Lassiter, B. S. Miller, R. J. Doyle (1999) A new mechanism of action of fluoride on streptococci, Biochem. Biophys. Acta, 1428, 415-423. 
[8] S. Luengpailin, J. A. Banas and R. J. Doyle (2000) Modulation of glucan binding protein activity in streptococci by fluoride. Biochem. Biophys. Acta, 1474, 346-352.

[9] Jenkins, G. N. (1999) Review of fluioride research since 1959. Arch. Oral Biol. 44: 985-992.

[10] D. L. Nelson, M. M. Cox (2000) Lehninger Principles of Biochemistry, 3th ed. pp. 527-546, Worth Publishers, New York.

[11] Marquis, R.E. (1995) Oxigen metabolism, oxidative stress and acid-base physiology of dental plaque biofilms. J. Industr. Microbiol. 15: 198-207.

[12] I. G. Chestnutt, T. W. MacFarlane, K. W. Stephen, (1994) An in vitro investigation of the cariogenic potential of oral Streptococci, Arch. Oral Biol. 39(7): 589-593.

[13] H. Maehara, Y. Iwami, H. Mayanagi and N. Takahashi (2005) Synergistic inhibition by combination of fluoride and xylitol o glycolysis by mutans Streptococci and its biochemical mechanism. Caries Res. 39:521-528.

[14] T. Suzuki, J. Tagami, N. Hanada (2000) Role of F1Fo-ATPase in the growth of Streptpcoccus mutans GS5. J. Applied Microbiol. 88:555-562

[15] P.P. Magalhães, T. P. Paulino, G. thedei Jr and P. Ciancaglini. (2004) Kinetic characterization of P-type ATPase from Streptococcus mutans Comp. Biochem. Physiol.140: 589-597.

[16] P.P. Magalhães, T. P. Paulino, G. thedei Jr, R. E. Larson and P. Ciancaglini (2003) A $100 \mathrm{KDa}$ vanadate and lanzoprazole-sensitive ATPase from Streptococcus mutans membrane. Arch. Oral Biol. 48: 815 - 824.

[17] S. G. Dashper, E. C. Reynolds (1990) Characterization of transmembrane movement of glucose and glucose analogs in Streptococcus mutans Ingbritt, J. Bacteriol. 172(2), 556-563.

[18] T. P. Paulino, R. O. Andrade, G. C. M. Bruschi-Thedei, G. Thedei Jr., P. Ciancaglini (2004) The effect of Carbon source and Fluoride Concentration in the Streptococcus mutans Biofilm Formation. Biochem. Mol. Biol. Educ. 32, 331-335.

[19] T. P. Paulino, M. Cardoso Jr, G. C. M. Bruschi-Thedei, P. Ciancaglini (2003) Fermentable and non-fermentable sugars. A simple experiment of anaerobic metabolism, Biochem. Mol. Biol. Educ. 31, 180-184.

[20] I. R. Hamilton (1987) Effects of fluoride on enzymatic regulation of bacterial carbohydrate metabolism. Caries Res. 11:262-291.

[21]G. Spatafora, K. Rohrer, D. Barnard and S. Michalek (1995) A Streptococcus mutans mutant that syntetizes elevated levels of intracellular polisacharude is hipercariogenic in vivo. Infect. Immun. 63: 2556-2563.

[22] M. R. Wegman, A. D. Eisenberg, M. E. Curzon, S. L. Handelman (1984) Effects of fluoride, lithium and strontium on intracellular polysaccharide accumulation in $S$. mutans and A. viscosus J. Dent. Res. 63(9), 1126-1129 


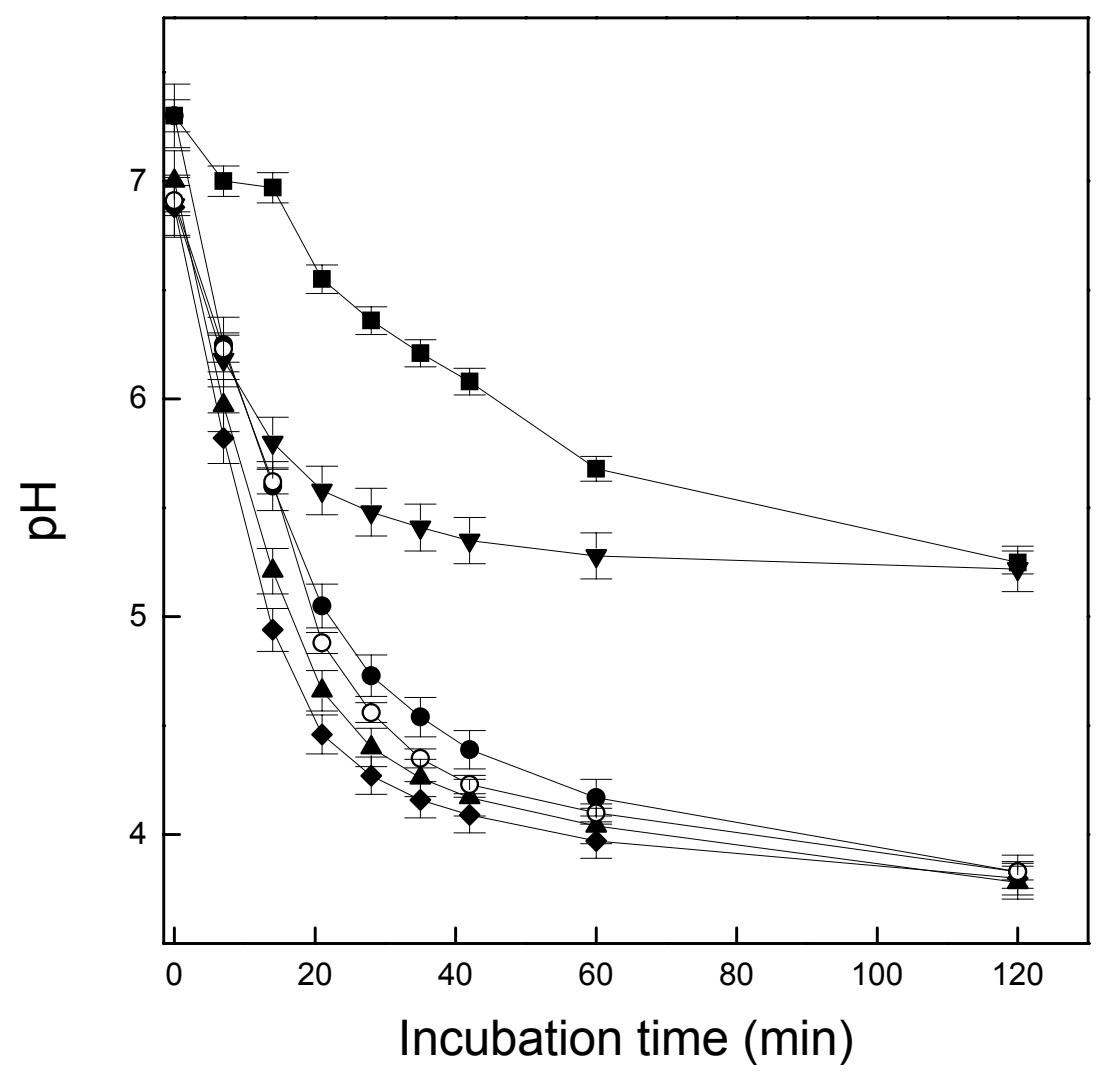

Figure 1: $\mathrm{pH}$ of cell suspension of $S$. mutans supplied with different carbon sources. A cell suspension was supplied with: $(\boldsymbol{O})$ Glucose; ( $\mathbf{\Delta})$ Fructose; ( $\boldsymbol{\nabla})$ Xylose; ( $)$ Maltose; (O) Sucrose and ( $\mathbf{a})$ without carbon source. Data represent mean values $(n=3)$ and error bars represent standard deviations. 


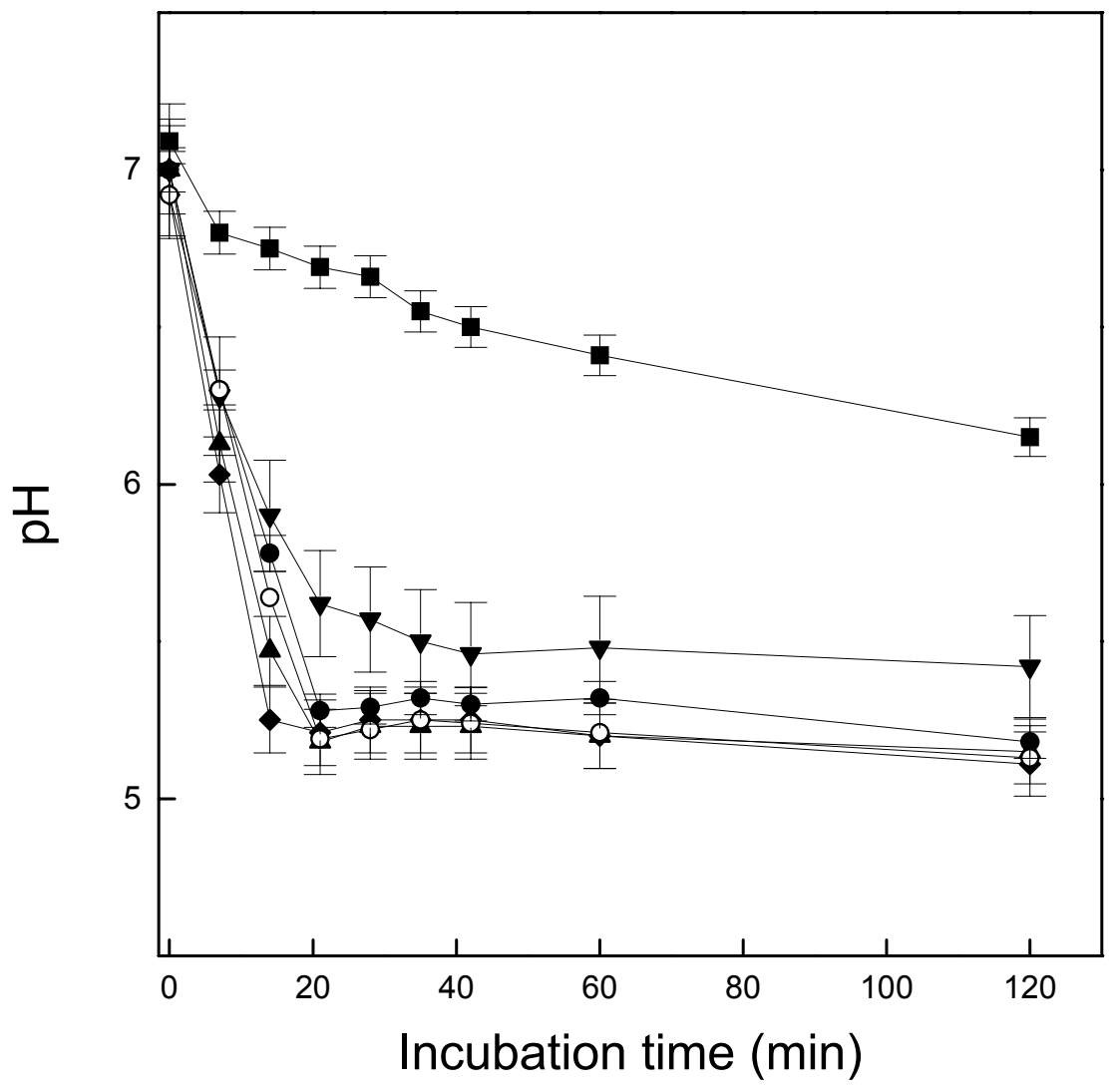

Figure 2: $\mathrm{pH}$ of cell suspension of $S$. mutans supplied with different carbon sources, in the presence of $1 \mathrm{mmol} / \mathrm{L}$ fluoride. A cell suspension was supplied with: (O) Glucose; $(\boldsymbol{\Delta})$ Fructose; ( $\boldsymbol{\nabla})$ Xylose; ( $)$ Maltose; (O) Sucrose and (घ) without carbon source. Data represent mean values $(n=3)$ and error bars represent standard deviations. 